Florida International University

FIU Digital Commons

FIU Electronic Theses and Dissertations

University Graduate School

$10-15-2018$

\title{
Factors Affecting Green Turtle Foraging Ecology Across Multiple Spatial Scales
}

\author{
Elizabeth Rose Whitman \\ Florida International University, ewhit041@fiu.edu
}

Follow this and additional works at: https://digitalcommons.fiu.edu/etd

Part of the Behavior and Ethology Commons, Biology Commons, Other Plant Sciences Commons, and the Population Biology Commons

\section{Recommended Citation}

Whitman, Elizabeth Rose, "Factors Affecting Green Turtle Foraging Ecology Across Multiple Spatial Scales" (2018). FIU Electronic Theses and Dissertations. 3870.

https://digitalcommons.fiu.edu/etd/3870

This work is brought to you for free and open access by the University Graduate School at FIU Digital Commons. It has been accepted for inclusion in FIU Electronic Theses and Dissertations by an authorized administrator of FIU Digital Commons. For more information, please contact dcc@fiu.edu. 


\section{FLORIDA INTERNATIONAL UNIVERSITY}

Miami, Florida

\section{FACTORS AFFECTING GREEN TURTLE FORAGING ECOLOGY ACROSS} MULTIPLE SPATIAL SCALES

A dissertation submitted in partial fulfillment of

the requirements for the degree of

DOCTOR OF PHILOSOPHY

in

BIOLOGY

by

Elizabeth R. Whitman 
To: Dean Michael R. Heithaus

College of Arts, Sciences and Education

This dissertation, written by Elizabeth R. Whitman, and entitled Factors Affecting Green Turtle Foraging Ecology Across Multiple Spatial Scales, having been approved in respect to style and intellectual content, is referred to you for judgment.

We have read this dissertation and recommend that it be approved.

William Anderson

Maureen Donnelly

James Fourqurean

Yuying Zhang

Michael R. Heithaus, Major Professor

Date of Defense: October 15, 2018

The dissertation of Elizabeth R. Whitman is approved.

Dean Michael R. Heithaus

College of Arts, Sciences and Education

Andrés G. Gil

Vice President for Research and Economic Development and Dean of the University Graduate School

Florida International University, 2018 
(C) Copyright 2018 by Elizabeth R. Whitman

All rights reserved. 


\section{DEDICATION}

To my mother Linda Gardner and late grandfather Thomas Gardner whose small lessons

in the mechanics and value of the natural world and whose support made my pursuit of a higher education possible. 


\section{ACKNOWLEDGMENTS}

Most importantly, I must thank my major professor, Dr. Michael Heithaus, whose contagious excitement for research, ability to provide multiple knowledgeable perspectives to any topic of discussion, and complete confidence in my abilities propelled me to pursue a diversity of research and will never cease to inspire me. I thank the members of my committee for their support and patience throughout the research and writing process. Dr. Maureen Donnelly’s honesty without any sugarcoating, and reminders of the reasons I have to be confident and motivated were exactly what I needed at times. Dr. Yuying Zhang gave me the foundation I needed to develop my quantitative analysis using $\mathrm{R}$. The wealth of knowledge of ecosystem processes I would gain from even a quick meeting with Dr. James Fourqurean is invaluable. Dr. William Anderson continued to support me and contribute a positive and knowledgeable perspective even when my core projects did not include stable isotope analysis.

I thank Dr. Jeremy Kiszka whose worldly perspective and collaboration make our work in the French West Indies possible and who, even when the approach is not immediately obvious, is always striving for the betterment of everyone in our lab. Kirk Gastrich helped me to get my projects off the ground and set an example of how to deal gracefully with the unexpected. I thank Dr. Jordan Thomson for his assistance during my first field season and idea development, and for his continued collaboration. I also thank

all who have come through our lab before and since me for providing unending personal and professional support both directly and by serving as examples for me to follow.

On-site logistical support facilitated my field research. Friends of the Environment and all associated with them helped me every step of the way during my 
time on Abaco, and through my work with them I have gained lifelong friendships and future collaborations. In the French West Indies DEAL Guadeloupe, the National Park of Guadeloupe, DEAL Martinique, and Reserve Naturelle de Saint Martin provided permits and an abundance of assistance in the field.

Undergraduate and volunteer field assistants not only made the research possible, but also a great deal of fun. Through her organization, The Science Exchange, Katherine Comer Santos recruited the best of the best interns Liberty Boyd, Ryley Parent, Laura Thornton, and Justine Thomson, who dedicated months of their lives to work as volunteers on my projects. Many others, at all field sites, contributed their time and resources to my research, and I will be forever grateful to them all. The outstanding leadership and work ethic of my lab assistants, especially of Laura García Barcia, Dominique Brito, Alec Colosi, and Maddy Mishael Pamela Murata kept my projects on track by supervising dozens of others spending hundreds of hours prepping samples and extracting data from videos.

This dissertation would not have been possible without the financial support from Florida International University in the form of four years of teaching assistantship, research assistantships, a Dissertation Evidence Acquisition Fellowship, and a Dissertation Year Fellowship. Additional financial support for field work and travel were provided by the TOTAL Foundation, Vulcan Inc. and Global FinPrint, the PADI Foundation, the Judith Evans Parker Travel Award Scholarship, the Great Lakes National Scholarship Program, and multiple conference travel grants.

Without the love and support of my friends and family, I would not have been able to pursue this degree. I would especially like to thank my mother, Linda Gardner, for 
inspiring me from an early age to be curious about the world around me and for always being just a phone call away, and my partner in life, Mauricio Bolivar, who, despite not always understanding the process, sees my passion for pursuing my goals and continually strives to find ways to support me. 


\section{ABSTRACT OF THE DISSERTATION \\ FACTORS AFFECTING GREEN TURTLE FORAGING ECOLOGY ACROSS \\ MULTIPLE SPATIAL SCALES}

by

Elizabeth R. Whitman

Florida International University, 2018

Miami, Florida

Professor Michael R. Heithaus, Major Professor

The hierarchical levels at which resource selection occurs can have important consequences for individual and population energy budgets and structure the impacts of a forager on its ecosystem. Assessing factors affecting resource selection of large marine herbivores across scales is important because of their potentially large impacts on seagrass community dynamics and historical and current changes in their population sizes and those of their potential predators. I explored the factors (predation risk, resource abundance, quality and identity) affecting resource use of large marine herbivores (green turtles, Chelonia mydas) from the scale of habitat patches to forage species within patches. I used a combination of in-water surveys, aerial drone video transects, baited camera surveys, and seagrass community and nutrient content analyses to provide insights into resource use by turtles in multiple ecological contexts.

In Abaco, The Bahamas I found relatively intact shark populations, including apex predators, relative to other parts of the Caribbean. In the context of healthy predator populations in Abaco, I tested a priori predictions rooted in Ideal Free Distribution (IFD) theory. Green turtles off Abaco deviated from predictions of an IFD determined by the 
standing stocks of seagrass. Instead, distributions are consistent with predictions of the foraging arena hypothesis with turtles largely restricted to safe habitat patches and selecting locations within these where seagrass $\mathrm{N}$ content is relatively high.

Marine invasive species can have detrimental effects on coastal ecosystems and economies. Therefore, understanding the effects of, and factors influencing the rate of spread of the invasive seagrass Halophila stipulacea in the Caribbean is important. In the French West Indies (Guadeloupe, Martinique and St. Martin), I investigated foraging preferences for native versus invasive seagrass species and whether green turtles might facilitate or attenuate the invasion through their choice of habitats and feeding patterns. Green turtle distributions were correlated with native seagrass distributions. Also, despite similar nutrient contents, turtles preferred feeding on native seagrasses irrespective of their relative abundance within a patch. These results suggest that, as predicted by the Enemy Release Hypothesis, green turtles likely facilitate the invasion and spread of the invasive seagrass that may reduce energy flow into turtle populations. 


\section{TABLE OF CONTENTS}

CHAPTER

PAGE

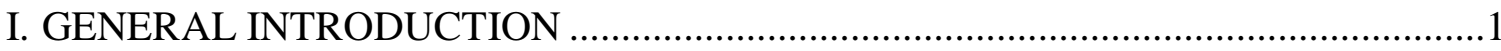

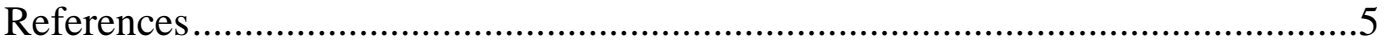

II. SPATIAL VARIATION IN THE RELATIVE ABUNDANCE AND SPECIES COMPOSITION OF SHARK COMMUNITIES IN NEARSHORE WATERS

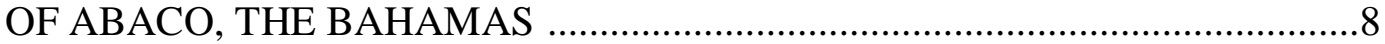

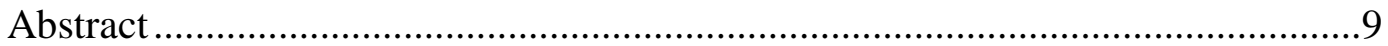

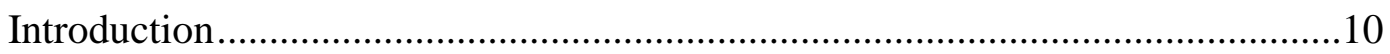

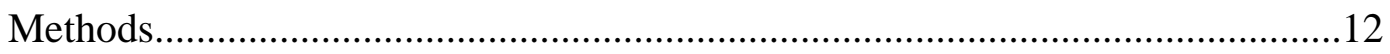

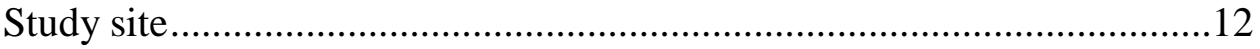

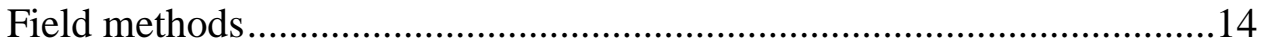

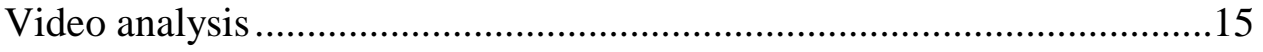

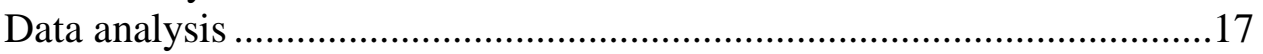

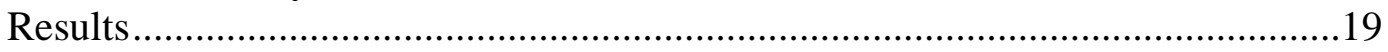

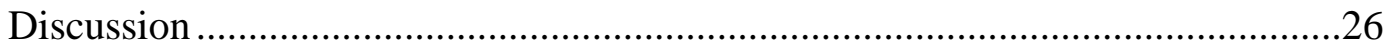

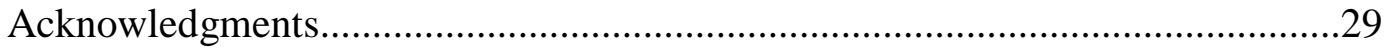

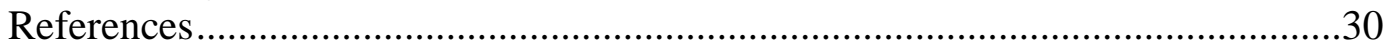

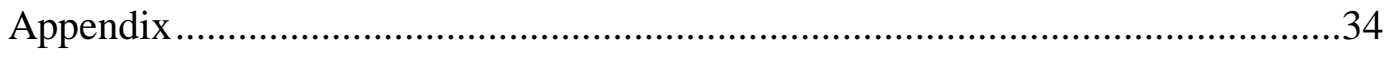

III. MULTI-LEVEL HABITAT SELECTION BY A LARGE MARINE HERBIVORE (CHELONIA MYDAS) IN A SHALLOW COASTAL ECOSYSTEM: THE INFLUENCE OF PREDATION RISK, FOOD

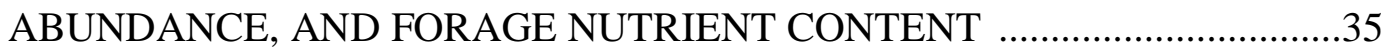

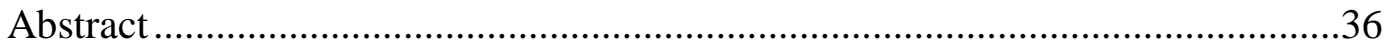

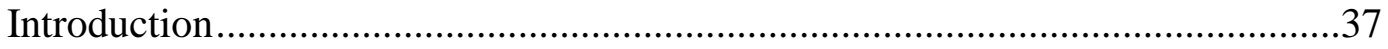

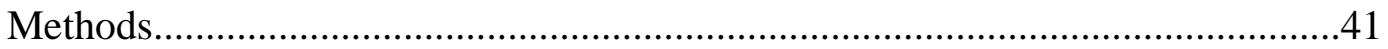

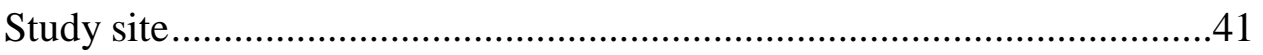

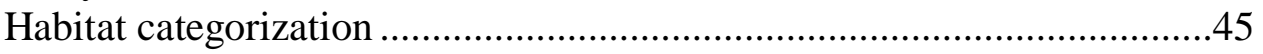

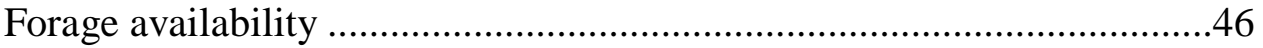

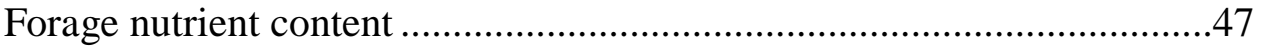

Predator relative abundance ..............................................................48

Turtle abundance and distributions ....................................................49

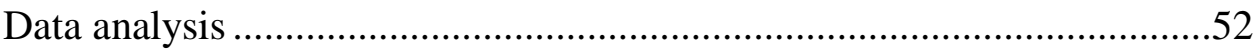

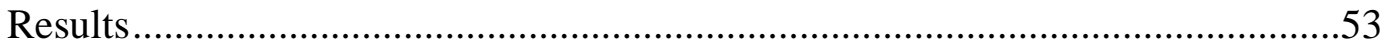

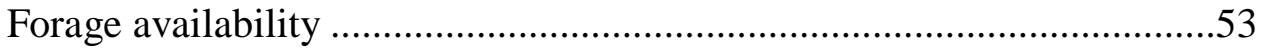

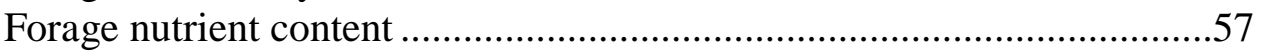

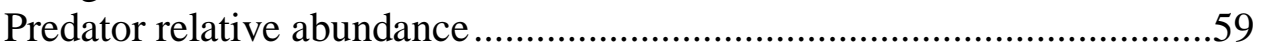

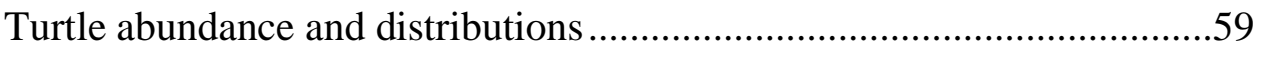

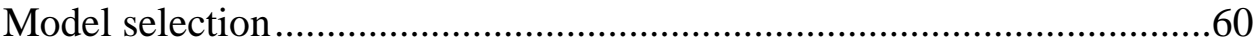

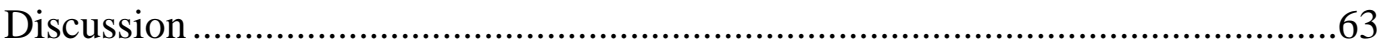




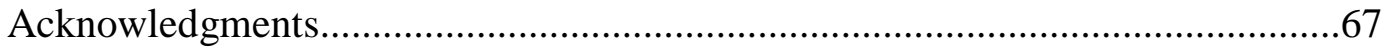

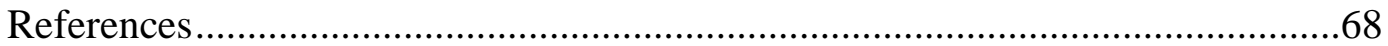

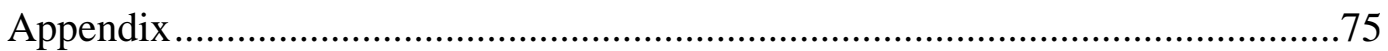

\section{LARGE-BODIED FORAGING HABITAT USE AND RESOURCE SELECTION} IS AFFECTED BY THE INVASIVE SEAGRASS, HALOPHILA STIPULACEA, IN THE FRENCH WEST INDIES .............................................

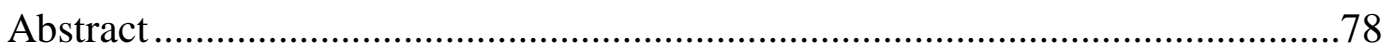

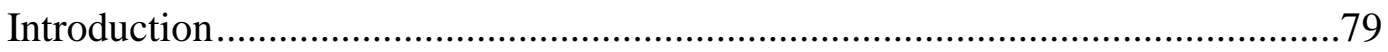

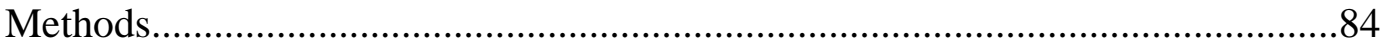

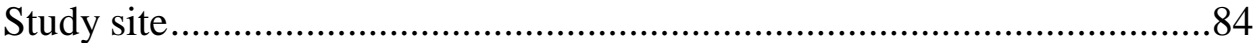

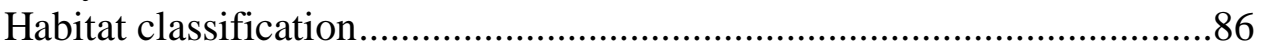

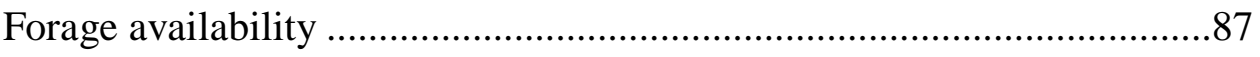

Nutrient content analysis...................................................................... 89

Turtle abundance and distributions .......................................................90

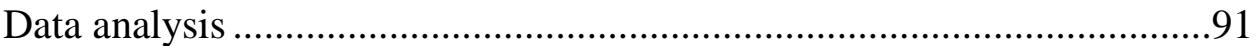

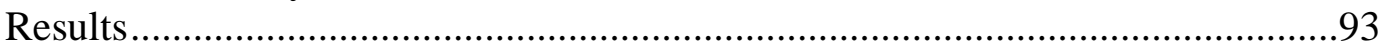

Forage availability ………………………………….......................93

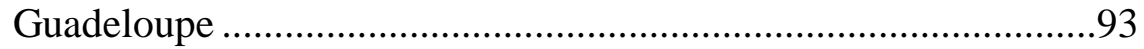

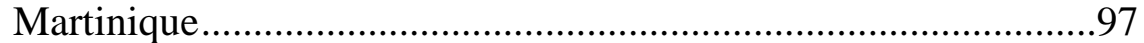

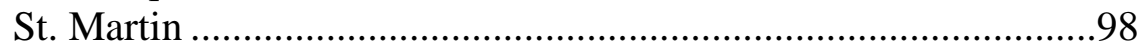

Forage nutrient content ........................................................................ 101

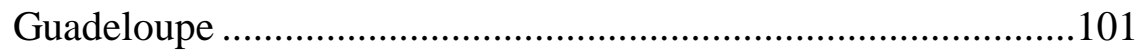

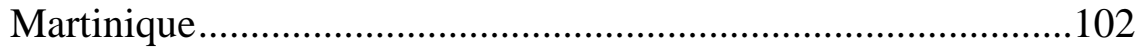

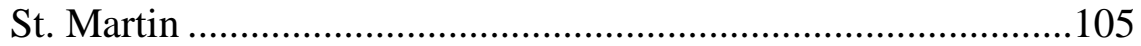

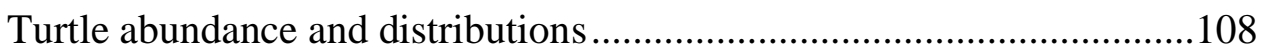

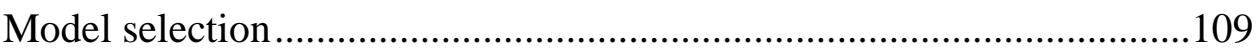

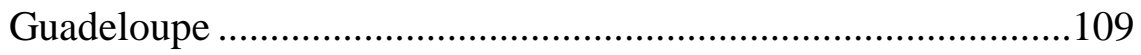

Martinique..........................................................................111

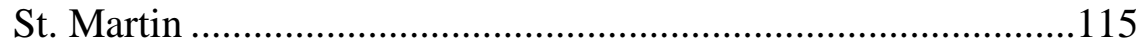

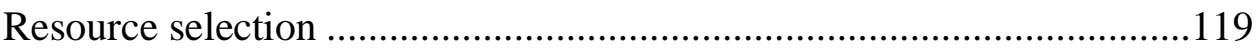

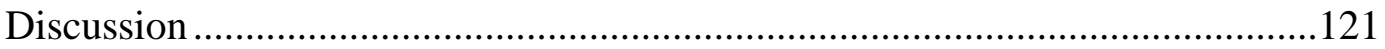

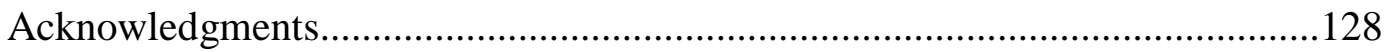

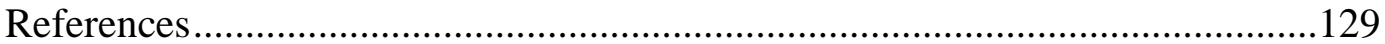

V. GREEN TURTLE FORAGING PREFERENCES FOR NATIVE SEAGRASSES

COULD FACILITATE THE HALOPHILA STIPULACEA INVASION OF

THE CARIBBEAN SEA: A TEST OF THE ENEMY RELEASE

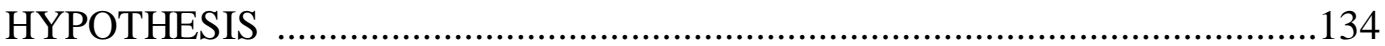

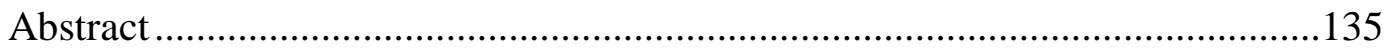

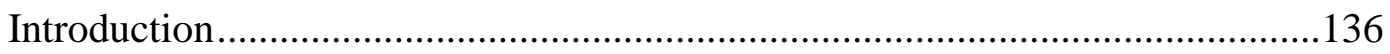

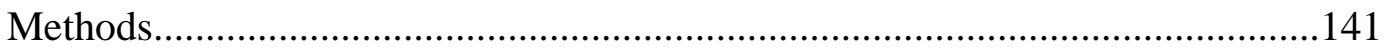

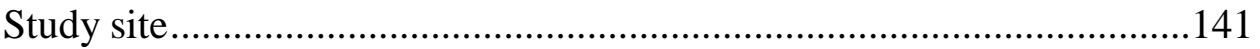

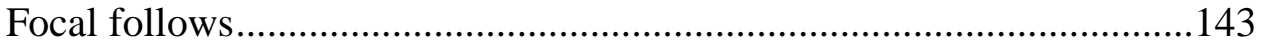

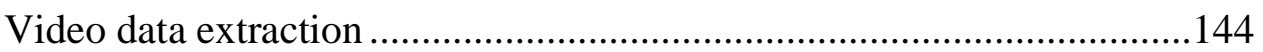


Nutrient content analysis.............................................................. 145

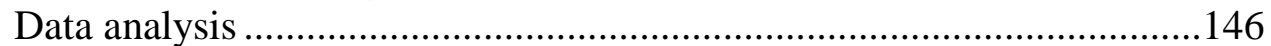

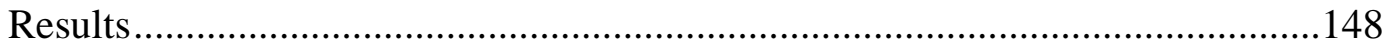

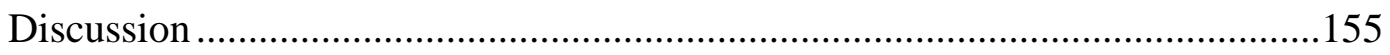

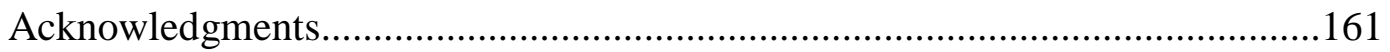

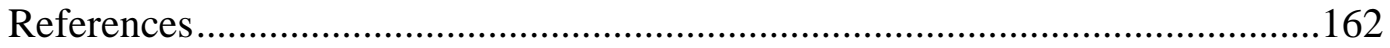

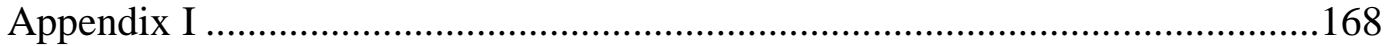

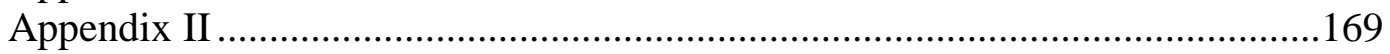

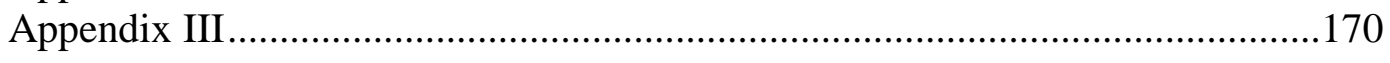

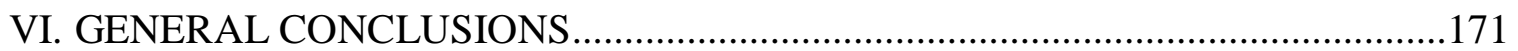

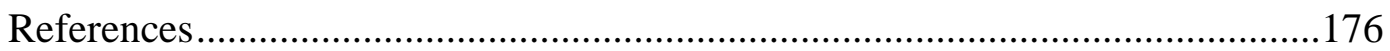

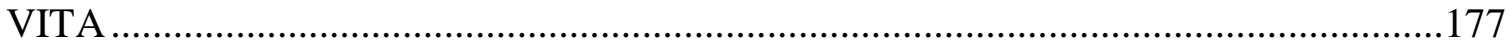


TABLE

\section{LIST OF TABLES}

CHAPTER II.

Table 1: Summary of BRUVs. Total BRUVs only include usable BRUVs; total hours are the sum of video time analyzed; mean hours (SD) are the average length of video time analyzed per BRUV

Table 2: Results of GLMM testing for differences in presence/absence and maxN between reef and bay habitats; shaded $P$ s denote significant differences between habitat types; NA signifies not enough observations for analysis

Table A: Shark species presence/absence observed per species: number of videos with presence (count), percent of videos with presence $(\%)$

\section{CHAPTER III.}

Table 1: Braun-Blanquet density scores (Fourqurean et al., 2001)

Table 2: Wilcoxon rank sum test results of turtle sighting density and habitat variables between habitats; Significance codes: 0 '***', $0.001^{\text {' } * *,}, 0.01^{\prime *} *, 0.05^{\prime}$ '’

Table 3: Model selection table with models ranked by AIC score from best fitting model to worst, where $\mathrm{K}$ is the number of parameters in the model, AICc is the information criterion for each model, $\delta \mathrm{AICc}$ is the difference between the AIC of respective model and the best fitting model, ModelLik is the relative likelihood of the model given the data, AICcWt are the Akaike weights and indicate the level of support for the model being the most parsimonious, LL is the log-likelihood, and Cum.Wt is the cumulative model weight (Mazerolle, 2017)

Table 4: Results of generalized linear mixed effects best fit model; Significance codes:

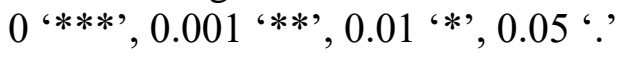

Table A: Backward reduced fixed-effect table with Satterthwaite's degrees of freedom method used to compute the denominator degrees of freedom (DenDF); The simply additive model yielded the same results, but interactions are included in

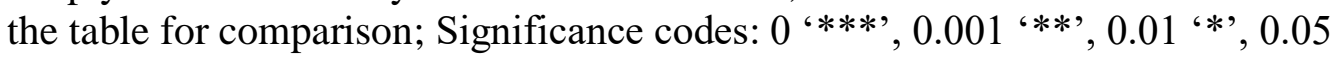
$\because$,

Table B: Results from the best fit linear mixed effects model; Significance codes: 0

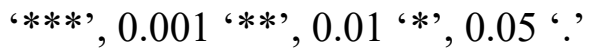




\section{CHAPTER IV.}

Table 1: Number of sampling plots and methods for macrophyte abundance and nutrient content collection; dashes indicate no data collection

Table 2: Braun-Blanquet abundance scores of each macrophyte species; the score for each sampling point is the average of scores given to each species based on this scale within four quadrats at each point; reproduced from (Fourqurean et al., 2001)

Table 3: Mean and standard deviations of Braun-Blanquet scores for each site and season

Table 4: C, N, P content and their ratios $\pm \mathrm{SD}$ of calcareous green algae (ACG), $H$. stipulacea $(\mathrm{Hs}), H$. wrightii $(\mathrm{Hw})$, S. filiforme $(\mathrm{Sf})$, T. testudinum $(\mathrm{Tt})$ off Guadeloupe .....

Table 5: Wilcoxon rank sum test results of nutrients among seagrass species off

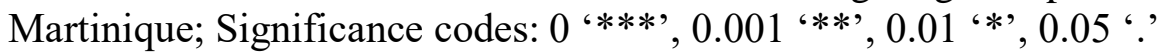

Table 6: $\mathrm{C}, \mathrm{N}, \mathrm{P}$ content and their ratios $\pm \mathrm{SD}$ of calcareous green algae (ACG), other algae (AO), H. stipulacea $(\mathrm{Hs}), H$. wrightii $(\mathrm{Hw})$, S. filiforme $(\mathrm{Sf}), T$. testudinum $(\mathrm{Tt})$ off Martinique

Table 7: Wilcoxon rank sum test results of nutrients among seagrass species off St.

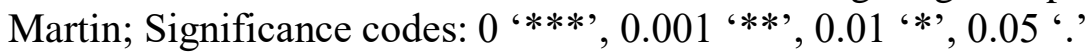

Table 8: C, N, P content and their ratios \pm SD of calcareous green algae (ACG), other algae (AO), H. stipulacea $(\mathrm{Hs}), H$. wrightii $(\mathrm{Hw}), S$. filiforme $(\mathrm{Sf}), T$. testudinum $(\mathrm{Tt})$ off St. Martin.

Table 9: Turtle sighting densities (Turtles/ha), total turtle sightings, transect length sum and total area surveyed for each site and sampling events.

Table10: Model selection table of turtle sightings in Guadeloupe with models ranked by AIC score from best fitting model to worst, where $\mathrm{K}$ is the number of parameters in the model, AICc is the information criterion for each model, $\delta \mathrm{AICc}$ is the difference between the AIC of respective model and the best fitting model, ModelLik is the relative likelihood of the model given the data, AICcWt are the Akaike weights and indicate the level of support for the model being the most parsimonious, LL is the log-likelihood, and Cum.Wt is the cumulative model weight (Mazerolle, 2017). * represents a test of the interaction and individual variables. 
Table 11: Results of generalized linear mixed effects best fit model for Guadeloupe;

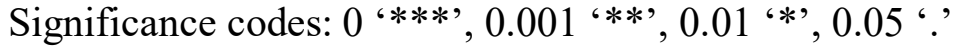

Table 12: Model selection table of turtle sightings in Martinique with models ranked by AIC score from best fitting model to worst, where $\mathrm{K}$ is the number of parameters in the model, AICc is the information criterion for each model, $\delta \mathrm{AICc}$ is the difference between the AIC of respective model and the best fitting model, ModelLik is the relative likelihood of the model given the data, AICcWt are the Akaike weights and indicate the level of support for the model being the most parsimonious, LL is the log-likelihood, and Cum.Wt is the cumulative model weight (Mazerolle, 2017). * represents a test of the interaction and individual variables

Table 13: Results of generalized linear mixed effects best fit model for Martinique; Significance codes: 0 '***', $0.001^{\text {‘ } * *,}, 0.01^{\text {‘*’ }}$, $0.05^{\prime}$.'

Table 14: Model selection table of turtle sightings in St. Martin with models ranked by AIC score from best fitting model to worst, where $\mathrm{K}$ is the number of parameters in the model, AICc is the information criterion for each model, $\delta \mathrm{AICc}$ is the difference between the AIC of respective model and the best fitting model, ModelLik is the relative likelihood of the model given the data, AICcWt are the Akaike weights and indicate the level of support for the model being the most parsimonious, LL is the log-likelihood, and Cum.Wt is the cumulative model weight (Mazerolle, 2017). * represents a test of the interaction and individual variables

Table 15: Results of generalized linear mixed effects best fit model for St. Martin;

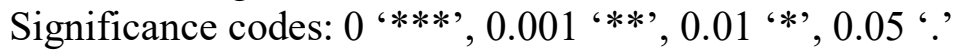

\section{CHAPTER V.}

Table 1: $P$ values from GLM testing the effect of relative abundance on the number of bites taken (Factor); Hs (H. stipulacea), Sf (S. filiforme), and Algae (macroalgae) and all possible interactions were tested; asterisks represent significant affects

Table A: Post-hoc comparisons among macrophytes using the Tukey's test (alpha = $0.05)$ for $\% \mathrm{C}, \% \mathrm{~N}, \mathrm{C}: \mathrm{N}, \mathrm{C}: \mathrm{P}$, and $\mathrm{N}: \mathrm{P}$.

Table B: Selectivity test statistic (Khi2Lj), degrees of freedom (df), $P$; Selection Ratios (Wi) for each resource: $H$. stipulacea $(\mathrm{Hs}), S$. filiforme $(\mathrm{Sf})$, macroalgae (Algae); Resource with positive selection: NA indicates turtles that did not feed selectively 


\section{LIST OF FIGURES}

FIGURE

PAGE

\section{CHAPTER II.}

Figure 1: Map of The Bahamas shark sanctuary (left) and the study area offshore of Great Abaco (right). The white dash delineates the EEZ of The Bahamas that serves as a shark sanctuary. Individual BRUV sets are displayed with black dots in the right panel.

Figure 2: BRUVs (A) were set in both reef (B) and seagrass (C) habitats. We calculated $\operatorname{maxN}$ separately for each species. In B), five Caribbean reef sharks are observable while, a single lemon shark is shown in $\mathrm{C}$ )

Figure 3: Location of occurrences of all shark species observed on BRUVs. The size of dots reflects maxN on a deployment.

Figure 4: Species-specific occurrence and maxN across habitat types. Observations per species in reef habitat (light bars) and bay habitat (dark bars); top: percent of BRUVs with species observation; middle: mean of maxN when species is present $(\operatorname{maxN}>0) \pm \mathrm{SE}$; bottom: mean maxN including videos with species absent; asterisks denote significant differences in presence and absence or maxN values between habitat types (Table 2)

Figure 5: Mean BRUV diversity (excluding BRUVs with zero observations) and total richness of each site, habitat type and total; top: mean BRUV diversity $( \pm \mathrm{SE})$ per category; bottom: number of species observed per category (richness).

Figure 6: Total site-level sum of maxN broken down by species

\section{CHAPTER III.}

Figure 1: Bight of Old Robinson, along the east coast of Great Abaco (inset). The grid divides the bay into $500 \mathrm{~m}$ x $500 \mathrm{~m}$ cells. Orange dots are turtle sightings .

Figure 2: Green turtle captured in a tidal creek north of the Bight of Old Robinson. The scratches and puncture marks on the carapace, plastron, and soft tissue are potential evidence of shark inflicted injuries

Figure 3: Habitat assignments of cells within the study area. $\mathrm{C}=$ creek (pink), $\mathrm{N}=$ nearshore (green), and $\mathrm{O}=$ open (blue). Cells not included in study are uncolored 
Figure 4: Still frames from drone video taken by DJI Phantom 3 Advanced; Top: view from the tidal creeks looking into the Bight of Old Robinson; Bottom: turtle sighting during drone transect in tidal creek with full field of view (left) and magnified (right)

Figure 5: Box and whisker plots where the midline is the median, upper and lower limits of the box represent the $75^{\text {th }}$ and $25^{\text {th }}$ percentile, whiskers extend to minimum and maximum values except for data exceeding 1.5 times the interquartile range and are displayed as dots (possibly outliers). Spatial variation in mean Braun-Blanquet scores of seagrass for A) T. testudinum (Tt), B) S. filiforme (Sf), C) H. wrightii (Hw), and D) total seagrass cover (sum of scores of all seagrasses can exceed the max score of 5 because of the broad scoring categories (Fourqurean et al., 2001)

Figure 6. Mean Braun-Blanquet scores of macroalgae for A) calcareous green algae, B) other non-calcareous green algae, C) red and brown algae, and D) total macroalgae cover (sum of scores of all macroalgae can exceed the max score of 5 because of the broad scoring categories (Fourqurean et al., 2001)

Figure 7: Spatial variation in nutrient content of seagrasses. Left (top-bottom): C, N, and $\mathrm{P}$ content $T$. testudinum per habitat; Right: Ratios of $\mathrm{C}: \mathrm{N}, \mathrm{C}: \mathrm{P}$, and $\mathrm{N}: \mathrm{P}$ for T. testudinum per habitat; the dashed lines represent the seagrass Redfield ratio. 58

Figure 8: Turtle sighting density per habitat.

Figure 10: Turtle sightings per ha by $\% \mathrm{~N}$ content and Braun-Blanquet scores $T$. testudinum

\section{CHAPTER IV.}

Figure 1: Juvenile green turtle resting in a mixed seagrass meadow in Malendure Bay, Guadeloupe; S. filiforme (native): long cylindrical blades; H. stipulacea (invasive): short, densely packed, paddle-shaped blades.

Figure 2: The study was conducted in the Lesser Antilles (left) within the Caribbean Sea (inset). One bay on the islands of St. Martin (top right), Guadeloupe (center right) and Martinique (bottom right) were selected based on the presence of turtles and mixed beds of invasive and native seagrasses .86

Figure 3: Survey effort in ha surveyed per site per sampling event. Cells on the grid are $100 \mathrm{~m} \times 100 \mathrm{~m}$. Color breakpoints were autogenerated by QGIS 
Figure 4: Braun-Blanquet abundance scores for Spring 2016 (S16) and Spring 2017 (S17) from Guadeloupe. The midline of the boxplot is the median, upper and lower limits of the box represent the $75^{\text {th }}$ and $25^{\text {th }}$ percentile, whiskers extend to minimum and maximum values except for data exceeding 1.5 times the interquartile range, which are displayed as dots (possible outliers)

Figure 5: Braun-blanquet abundance scores for macrophytes of Martinique Spring 2016 (S16) and Spring 2017 (S17). The midline of the boxplot is the median, upper and lower limits of the box represent the $75^{\text {th }}$ and $25^{\text {th }}$ percentile, whiskers extend to minimum and maximum values except for data exceeding 1.5 times the interquartile range, which are displayed as dots (possible outliers). 98

Figure 6: Braun-blanquet abundance scores for macrophytes of St. Martin Fall 2016 (F16) and Spring 2017 (S17). The midline of the boxplot is the median, upper and lower limits of the box represent the $75^{\text {th }}$ and $25^{\text {th }}$ percentile, whiskers extend to minimum and maximum values except for data exceeding 1.5 times the interquartile range, which are displayed as dots (possible outliers).

Figure 7: Elemental composition of macrophytes off Guadeloupe; Left (top-bottom): $\mathrm{C}, \mathrm{N}$, and $\mathrm{P}$ content of calcareous green algae (ACG), $H$. stipulacea $(\mathrm{Hs}), H$. wrightii (Hw), S. filiforme (Sf), T. testudinum (Tt); Right: Ratios of C:N, C:P, and $\mathrm{N}: \mathrm{P}$ for each species; the dashed lines represent the seagrass Redfield ratio

Figure 8: Elemental composition of macrophytes off Martinique; Left (top-bottom): $\mathrm{C}, \mathrm{N}$, and $\mathrm{P}$ content of calcareous green algae (ACG), other algae (AO), $H$. stipulacea $(\mathrm{Hs})$, H. wrightii $(\mathrm{Hw})$, S. filiforme $(\mathrm{Sf})$, T. testudinum (Tt); Right: Ratios of C:N, C:P, and N:P for each species; the dashed lines represent the seagrass Redfield ratio

Figure 9: Elemental composition of macrophytes off St. Martin; Left (top-bottom): C, $\mathrm{N}$, and $\mathrm{P}$ content of calcareous green algae (ACG), other algae (AO), $H$. stipulacea $(\mathrm{Hs})$, H. wrightii $(\mathrm{Hw})$, S. filiforme (Sf), T. testudinum (Tt); Right: Ratios of C:N, C:P, and N:P for each species; the dashed lines represent the seagrass Redfield ratio

Figure 10: Mean turtle sightings per hectare for each sampling event and site

Figure 11: Relationship between turtle sighting densities (to account for effort) and Braun-Blanquet scores of S. filiforme off Guadeloupe. The shaded area represents the 95\% confidence interval; Left: including Braun-Blanquet scores equal to zero; Right: excluding Braun-Blanquet scores equal to zero 
Figure 12: Relationships between turtle sighting densities (to account for effort) and the interaction of T. testudinum and S. filiforme Braun-Blanquet scores off Martinique of; Top panel includes sum of Braun-Blanquet scores equal to zero. Bottom panel excludes sum of Braun-Blanquet scores equal to zero

Figure 13: Relationships between turtle sighting densities (to account for effort) and Braun-Blanquet scores off Martinique of; Top: T. testudinum and Bottom: $S$. filiforme abundances and turtle sightings. The shaded area represents the $95 \%$ confidence interval. Left panels include sum of Braun-Blanquet scores equal to zero. Right panels exclude sum of Braun-Blanquet scores equal to zero.

Figure 14: Relationships between turtle sighting densities (to account for effort) and Braun-Blanquet scores off St. Martin of; Top: the interaction of S. filiforme with T. testudinum and turtle sighting densities; Bottom: the interaction of $S$. filiforme with $H$. wrightii and turtle sighting densities. The shaded area represents the $95 \%$ confidence interval. Left panels include sum of BraunBlanquet scores equal to zero. Right panels exclude sum of Braun-Blanquet scores equal to zero

Figure 15: Relationships between turtle sighting densities (to account for effort) and Braun-Blanquet scores off St. Martin of; Top: T. testudinum, Middle: $S$. filiforme, and Bottom: $H$. wrightii Braun-Blanquet scores and turtle sighting densities. The shaded area represents the $95 \%$ confidence interval. Left panels include sum of Braun-Blanquet scores equal to zero. Right panels exclude sum of Braun-Blanquet scores equal to zero

Figure 16: Selection ratios for T. testudinum (Tt), S. filiforme (Sf), and H. stipulacea (Hs) off A) Guadeloupe, B) Martinique, and C) St. Martin Each point represents the selection ratio at one turtle sighting; Values above 1.0 (dashed line) indicate positive selection, values below 1.0 indicate avoidance, and values near 1.0 indicate no apparent preference.

\section{CHAPTER V.}

Figure 1: Conceptual diagram of predicted green turtle foraging behavior on two species if they A) prefer native seagrasses (dark circles), B) prefer invasive seagrass (gray circles), C) preferential to forage on the most abundant species, and D) display no foraging preference. Note, in (A) we assume that turtles would forage on the invasive species if it were the only forage available.

Figure 2: Malendure Bay lies on the west coast of Guadeloupe (inset). Seagrass nutrient content was measured at 12 locations within the study area (closed circles) 
Figure 3: Screen grab from a video of a green turtle during a focal follow. The outer box delineates the entire viewing area used for estimates of percent cover (i.e., the entire field of view). The white dotted line, defined by a box extending from between the foreflippers to several $\mathrm{cm}$ in front of the turtle's head, delineates the area immediately available to the turtle for foraging and was used for the estimates of percent cover for each seagrass species that were used for analysis.

Figure 4: Left: Mean nutrient compositions ( \pm SD) for macroalgae (Algae, $N=9$ ), $H$. stipulacea (Hs, $N=12$ ), and S. filiforme (Sf, $N=9$ ). Bars with different letters were significantly different from one another based on multiple post-hoc comparisons using the Tukey HSD test with alpha $=0.05$; Right: Elemental ratios of macrophyte tissue, dotted lines indicate seagrass Redfield ratios

Figure 5: Mean macrophyte composition immediately available to each individual turtle during focal follows; area not covered by macrophytes (Sand), macroalgae (Algae), T. testudinum (Tt), S. filiforme (Sf), H. stipulacea $(\mathrm{Hs})$; brackets indicate multiple follows of individuals

Figure 6: Selection ratios for S. filiforme (Sf), H. stipulacea (Hs), and macroalgae (Algae); Values above 1.0 indicate positive selection, values below 1.0 indicate avoidance, and values near 1.0 indicate no apparent preference

Figure 7: Proportion of total bites taken of each species for each turtle including macroalgae (Algae), T. testudinum $(\mathrm{Tt})$, S. filiforme $(\mathrm{Sf})$, H. stipulacea $(\mathrm{Hs})$, and "other" (unknown, mixed species and non-flora combined)

Figure 8: Bites per minute in monospecific meadows of $S$. filiforme $(\mathrm{Sf})$ and $H$. stipulacea $(\mathrm{Hs})$

Figure 9: Mean percentage of bites $( \pm$ SE) of Hs (orange) and Sf (blue) per bout across a range of relative availabilities. Total percentages less than 100 are due to bites of taxa other than seagrass. Error bars are SE, and are not visible when smaller than the size of the data point. Sfmono $=100 \% \mathrm{Sf}, \mathrm{Sf} 2 \mathrm{Xplus}=$ $\mathrm{Sf} \geq 2 \times \mathrm{Hs}=75-99 \% \mathrm{Sf}, \mathrm{Sfdom}=2 \times \mathrm{Hs}>\mathrm{Sf}>\mathrm{Hs}=51-74 \% \mathrm{Sf}$, equal $=\mathrm{Sf}$ $=\mathrm{Hs}=50 \% \mathrm{Sf}+50 \% \mathrm{Hs}, \mathrm{Hsdom}=2 \mathrm{x} \mathrm{Sf}>\mathrm{Hs}>\mathrm{Sf}=51-74 \% \mathrm{Hs}$, Hs $2 \mathrm{Xplus}$ $=\mathrm{Hs} \geq 2 \times \mathrm{Sf}=75-99 \% \mathrm{Hs}$, Hsmono $=100 \% \mathrm{Hs}$

Figure A: Selectivity indices for H. stipulacea (Hs), S. filiforme (Sf), and macroalgae (Algae) during multiple follows of individual turtles; G1501, G1504, G1608, and G1621 were followed twice each; G1604 and G1611 were followed four times each; asterisk denotes differences in selection among follows of the same individual 


\section{CHAPTER I}

GENERAL INTRODUCTION 
Large grazers occupy important positions in ecosystems across diverse settings. Many of them can have tremendous impacts on the structure and function of ecosystems (Johnson and Cushman, 2007; Waldram, Bond and Stock, 2008), but these impacts are influenced by decisions they make in the face of spatiotemporal variation in both topdown (i.e., risk from large-bodied predators; Heithaus et al. 2014; Wirsing, Heithaus, and Dill 2007) and bottom-up (e.g., forage quantity and quality, species invasions; (Power, 1992; Burkholder, Heithaus and Fourqurean, 2012) factors. Assessing the role of large herbivores in marine systems, therefore, is particularly important because of dramatic and virtually world-wide declines in populations of their predators (large sharks; Ferretti et al. 2010), ongoing conservation programs focused on large grazers (Aryal et al., 2017; Makecha and Ghosal, 2017; Mazaris et al., 2017), and major changes to the base of food webs through eutrophication, habitat destruction, and species invasions (Binzer et al., 2016; Mougi and Kondoh, 2016; David et al., 2017).

Green turtles (Chelonia mydas), whose primary food source in most populations is seagrass (Bjorndal, 1985), are endangered on a global scale (Jackson, 2001; Seminoff et al., 2007), but as a result of focused conservation and management efforts, some regional populations are increasing (Mazaris et al., 2017). As grazers, green turtles have the potential to affect seagrass communities (Fourqurean et al., 2010; Kelkar et al., 2013; Christianen et al., 2014). In Bermuda, where conservation efforts have been particularly successful and shark populations are reduced, unchecked grazing by green turtles has led to the collapse of some local seagrass meadows (Fourqurean et al., 2010), and despite the decline in seagrass availability, green turtles are not shifting away from seagrass as their major food source (Burgett et al., 2018). Therefore, my dissertation research focused on 
identifying the factors affecting green turtle foraging ecology, including food availability and predation risk, in multiple ecological contexts. I investigated the factors influencing turtle habitat use and foraging across three levels of Johnson (1980)'s hierarchy. In Abaco, The Bahamas I investigated how predation risk, food availability, and food quality (nutrient content) affect turtle habitat use at the scale of population home ranges and areas within the home ranges. In the French West Indies (FWI), I elucidated how habitat use within home ranges and food selection varied across gradients of native and invasive seagrass abundance and food quality.

In Chapter II, I investigated potential predation risk faced by turtles by conducting the first survey of abundance and species composition of sharks, the top non-human predator of sea turtles (Heithaus et al., 2008), in Abaco, The Bahamas. The Bahamas was established as a shark sanctuary in 2011 (S.I. No. 64 of 2011) and has relatively high species richness relative to other areas of the Caribbean (Ward-Paige et al., 2010; Brooks et al., 2011). I used baited remote underwater videos (BRUVs) to survey shark populations on four fringing reefs ( $>50 \mathrm{~km}$ combined length) and in two seagrass lagoons ( $9 \mathrm{~km}^{2}$ each). Most studies of green turtle foraging behavior have been conducted in areas with already depleted predator populations (e.g., Fourqurean et al., 2010; Kelkar et al., 2013; Christianen et al., 2014), with one notable exception in Shark Bay, Western Australia where green turtles in relatively good body condition avoided areas where they were likely to encounter tiger sharks despite the availability of high quality forage (Heithaus et al., 2007). In Chapter III, I used data from the shark surveys in Chapter II to help explore the importance of predation risk, food abundance and food quality on green turtle habitat using a priori predictions derived from Ideal Free Distribution (IFD) theory. 
While changes in predator abundance might have profound effects on the spatiotemporal pattern of turtle grazing, invasive species also have the potential to shape sea turtle habitat use and foraging and, in turn, turtles may either facilitate or attenuate the rate of invasion by marine plants. Halophila stipulacea, a seagrass native to the western Indian Ocean, has successfully spread to the Caribbean (Ruiz \& Ballantine, 2004; Willette et al., 2014). The invasive $H$. stipulacea is fast-growing, produces many seeds, and can tolerate a wide range of salinities, temperatures, light levels, and disturbance regimes (Short et al., 2010). Yet, little is known about the ecological consequences of the invasion of the Caribbean (Willette and Ambrose, 2012). In Chapter IV, I investigated space use of turtles within foraging areas across three sites in the French West Indies (Guadeloupe, Martinique and Saint Martin) that represent a gradient of invasive species presence. I conducted snorkel transect surveys of green turtle density, point surveys of the macrophyte community, and macrophyte nutrient content analysis to determine whether turtles avoided areas with high cover of invasive species, preferred such areas, or selected habitats irrespective to the overall composition of seagrass communities. In Chapter V, I tested the Enemy Release Hypothesis (Keane and Crawley, 2002) and the potential factors influence turtle foraging preferences of green turtles at the individual and population level using turtle focal follows and macrophyte nutrient content analysis off the west coast of Guadeloupe (French West Indies).

In my concluding chapter, I synthesize the results of the four studies to identify common patterns in green turtle, and more generally large herbivore, resource selection and suggest further avenues for research that will help us better understand the 
consequences of turtle behavioral decisions and more effectively manage marine ecosystems.

\section{References}

Aryal, A. et al. (2017). Global lessons from successful rhinoceros conservation in Nepal, Conservation Biology, 31(6), pp. 1494-1497. doi: 10.1111/cobi.12894.

Binzer, A. et al. (2016). Interactive effects of warming, eutrophication and size structure: Impacts on biodiversity and food-web structure, Global Change Biology, 22(1), pp. 220-227. doi: 10.1111/gcb.13086.

Bjorndal, K. A. (1985). Nutritional Ecology of Sea Turtles, American Society of Ichthyologists and Herpetologists, 1985(3), pp. 736-751.

Brooks, E. J. et al. (2011). Validating the use of baited remote underwater video surveys for assessing the diversity, distribution and abundance of sharks in the Bahamas, Endangered Species Research, 13(3), pp. 231-243. doi: 10.3354/esr00331.

Burgett, C. M. et al. (2018). Ontogenetic diet shifts of green sea turtles (Chelonia mydas) in a mid-ocean developmental habitat. Marine Biology, 165(2), 33. https://doi.org/10.1007/s00227-018-3290-6

Burkholder, D. A., Heithaus, M. R. and Fourqurean, J. W. (2012). Feeding preferences of herbivores in a relatively pristine subtropical seagrass ecosystem, Marine and Freshwater Research, 63(11), pp. 1051-1058. doi: 10.1071/MF12029.

Christianen, M. J. A. et al. (2014). Habitat collapse due to overgrazing threatens turtle conservation in marine protected areas, Proceedings of the Royal Society B: Biological Sciences, 281(20132890), p. 7. http://rspb.royalsocietypublishing.org/content/281/1777/20132890.short.

David, P. et al. (2017). Impacts of Invasive Species on Food Webs: A Review of Empirical Data, Advances in Ecological Research, 56, pp. 1-60. doi: 10.1016/bs.aecr.2016.10.001.

Ferretti, F. et al. (2010). Patterns and ecosystem consequences of shark declines in the ocean, Ecology letters, 13(8), pp. 1055-71. doi: 10.1111/j.14610248.2010.01489.x. 
Fourqurean, J. W. et al. (2010). Effects of excluding sea turtle herbivores from a seagrass bed: Overgrazing may have led to loss of seagrass meadows in Bermuda, Marine Ecology Progress Series, 419, pp. 223-232. doi: 10.3354/meps08853.

Heithaus, M. R. et al. (2007). State-dependent risk-taking by green sea turtles mediates top-down effects of tiger shark intimidation in a marine ecosystem. The Journal of Animal Ecology, 76(5), 837-44. https://doi.org/10.1111/j.13652656.2007.01260.x

Heithaus, M. R. et al. (2008). A review of lethal and non-lethal effects of predators on adult marine turtles, Journal of Experimental Marine Biology and Ecology, 356(1-2), pp. 43-51. doi: 10.1016/j.jembe.2007.12.013.

Heithaus, M. R. et al. (2014). Seagrasses in the age of sea turtle conservation and shark overfishing, Frontiers in Marine Science, 1, pp. 1-6. doi: 10.3389/fmars.2014.00028.

Jackson, J. B. C. (2001). What was natural in the coastal oceans?, Proceedings of the National Academy of Sciences of the United States of America, 98(10), pp. 54118. doi: 10.1073/pnas.091092898.

Johnson, B. E. and Cushman, J. H. (2007). Influence of a large herbivore reintroduction on plant invasions and community composition in a California grassland, Conservation Biology, 21(2), pp. 515-526. doi: 10.1111/j.15231739.2006.00610.x.

Johnson, D. H. (1980). The Comparison of Usage and Availability Measurements for Evaluating Resource Preference, Ecology, 61(1), pp. 65-71.

Keane, R., \& Crawley, M. (2002). Exotic plant invasions and the enemy release hypothesis. Trends in Ecology \& Evolution, 17(4), 164-170. https://doi.org/https://doi.org/10.1016/S0169-5347(02)02499-0

Kelkar, N. et al. (2013). Greener pastures? High-density feeding aggregations of green turtles precipitate species shifts in seagrass meadows. Journal of Ecology, 101(5), 1158-1168. https://doi.org/10.1111/1365-2745.12122

Makecha, R. N. and Ghosal, R. (2017). Elephant conservation: Reviewing the need and potential impact of cognition-based education, International Journal of Comparative Psychology, 30, pp. 0-7.

Mazaris, A. D. et al. (2017). Global sea turtle conservation successes, Science Advances, 3(9), p. e1600730. doi: 10.1126/sciadv.1600730. 
Mougi, A., and Kondoh, M. (2016). Food-web complexity, meta-community complexity and community stability. Scientific Reports, 6, 24478.

https://doi.org/10.1038/srep24478

Power, M. (1992). Top-down and bottom-up forces in food webs: do plants have primacy, Ecology, 73(3), pp. 733-746.

http://www.esajournals.org/doi/abs/10.2307/1940153

Ruiz, H., and Ballantine, D. L. (2004). Occurrence of the seagrass Halophila stipulacea in the tropical west Atlantic. Bulletin of Marine Science, 75(1), 131-135. http://www.ingentaconnect.com/content/umrsmas/bullmar/2004/00000075/00000 001/art00011

Seminoff, J. A. et al. (2007). Green sea turtle (Chelonia mydas) 5-year review: summary and evaluation. Silver Spring, MD and Jacksonville, FL: NMFS and USFWS.

Short, F. T. et al. (2010). Halophila stipulacea. The IUCN Red List of Threatened Species. Version 2014.2. 〈www.iucnredlist.org>. Downloaded on 23 October 2014.

Willette, D. A., \& Ambrose, R. F. (2012). Effects of the invasive seagrass Halophila stipulacea on the native seagrass, Syringodium filiforme, and associated fish and epibiota communities in the Eastern Caribbean. Aquatic Botany, 103, 74-82. https://doi.org/10.1016/j.aquabot.2012.06.007

Willette, D. A. et al. (2014). Continued expansion of the trans-Atlantic invasive marine angiosperm Halophila stipulacea in the Eastern Caribbean. Aquatic Botany, 112, 98-102. https://doi.org/10.1016/j.aquabot.2013.10.001

Waldram, M. S., Bond, W. J. and Stock, W. D. (2008). Ecological engineering by a mega-grazer: White Rhino impacts on a south African savanna, Ecosystems, 11(1), pp. 101-112. doi: 10.1007/s10021-007-9109-9.

Ward-Paige, C. a et al. (2010). Large-scale absence of sharks on reefs in the greaterCaribbean: a footprint of human pressures, PloS one, 5(8), p. e11968. doi: 10.1371/journal.pone.0011968.

Wirsing, A. J., Heithaus, M. R. and Dill, L. M. (2007). Can you dig it? Use of excavation, a risky foraging tactic, by dugongs is sensitive to predation danger, Animal Behaviour, 74(4), pp. 1085-1091. doi: 10.1016/j.anbehav.2007.02.009. 


\section{CHAPTER II}

SPATIAL VARIATION IN THE RELATIVE ABUNDANCE AND SPECIES COMPOSITION OF SHARK COMMUNITIES IN NEARSHORE WATERS OF ABACO, THE BAHAMAS 


\section{Abstract}

As upper trophic level predators, sharks may play important roles in shaping reef and seagrass ecosystems through both direct predation and risk effects. The overexploitation of sharks, therefore, has the potential to induce cascading effects on marine ecosystems. For example, in the absence of intact shark populations, sea turtle foraging behavior may be less constrained and population sizes may increase more rapidly and to larger population levels than in the presence of sharks. Therefore, increasing turtle populations have the potential to overgraze seagrass habitats. Protection of sharks began in The Bahamas in 2011, and the impacts on local shark populations are unknown at this time. Although previous studies suggest that shark populations of The Bahamas are less depleted than other areas of the Caribbean, many areas of The Bahamas have not been surveyed for shark populations. Here, I provide the first assessment of shark relative abundance, species composition and distribution in reef and seagrass habitats of Great Abaco. Between 2015 and 2016, I sampled four fringing reefs (>50 km combined reef length) and two seagrass-dominated bays $\left(9 \mathrm{~km}^{2}\right.$ each) adjacent to these reefs using baited remote underwater video (BRUV) systems. A total of 331 videos comprising 815 hours of recording were collected across all six sites. I identified nine shark species (Carcharhinus acronotus, Carcharhinus limbatus, Carcharhinus perezi, Galeocerdo cuvier, Ginglymostoma cirratum, Negaprion brevirostris, Rhizoprionodon spp., Sphyrna mokarran, and Sphyrna tiburo), with most species observed in both reef and seagrass habitats. Caribbean reef sharks (C. perezi) had the highest occurrence and relative abundance overall and dominated the reef habitats. Nurse sharks (G. cirratum) were also common on reefs and were the most abundant shark in seagrass habitats followed by the 
small-bodied blacknose shark (C. acronotus) and apex predatory tiger shark (G. cuvier). Only Carribean reef, blacknose, and nurse sharks ever exhibited maxN counts over 1. These results suggest that, similar to other areas of The Bahamas, shark populations of Great Abaco remain healthy compared to most areas of the Caribbean and still feature true apex predators that could play important roles in ecosystem dynamics.

\section{Introduction}

Apex predators can initiate cascading effects on ecosystem processes through their control of large herbivores and lower trophic level predators (Estes et al., 2011). As upper trophic level predators, sharks can impact marine ecosystems through consumptive effects, risk effects, and their interaction (Heithaus et al., 2008, 2010). For example, green turtles and dugongs in Shark Bay, Australia preferentially forage on seagrasses, and forego forage with greater nutritional value, when and where they are less likely to encounter tiger sharks (Heithaus et al., 2007; Wirsing, Heithaus and Dill, 2007; Burkholder et al., 2013). In the absence of intact shark populations, foraging behavior of prey species may go unchecked such as in the case where green turtles (Chelonia mydas) forage free of risk and may overgraze seagrass meadows (Fourqurean et al., 2010; Heithaus et al., 2014). Although the strength and context dependence of top-down impacts of sharks still requires considerable attention, the virtually worldwide overexploitation of sharks is likely affecting the current state of many marine systems (Ferretti et al., 2010; Worm et al., 2013; Estes et al., 2016). To slow and reverse these impacts, conservation strategies that include the creation of marine protected areas and 
improved fisheries management are being implemented in many regions (Ward-Paige, 2017).

Central to adaptive management are population baselines from which to monitor changes relative to varying human activities and interventions. Despite at least one quarter of elasmobranchs being threatened with extinction (Dulvy et al., 2014), there are few studies that provide baseline information for shark populations, especially those unaffected by humans (e.g., Shipley et al. 2017) Assessments of reef shark populations and communities are particularly important to evaluate the effectiveness of large-scale, shark specific no-take zones, referred to as "shark sanctuaries" that have been designated in numerous countries (Ward-Paige, 2017).

In The Bahamas, legal protection of sharks began in 2011 (S.I. No. 64 of 2011) following gillnet and longline prohibitions in the early 1990s. The legal protection established The Bahamas as a national shark sanctuary extending throughout the 628,026 $\mathrm{km}^{2}$ exclusive economic zone (EEZ). Fines are imposed for the take, trade, sale or possession of any shark species or their parts with exceptions made for permitted research (summarized by Ward-Paige, 2017). No standardized shark monitoring program exists, and with no commercial fishery and associated catch data, permanent research stations located on Bimini, and Eleuthera, provide the only time-series data for assessment (Shipley et al., 2017; Hansell et al., 2018). Surveys of sharks, particularly tiger sharks (see Heithaus et al., 2014), are particularly important in light of recent protections (2009) of sea turtles in The Bahamas EEZ. 
Here, I used baited remote underwater video (BRUV) surveys to 1) provide a snapshot of shark relative abundance and species composition, and 2) test for differences in the community composition and relative abundance of sharks from reef and adjacent seagrass habitats of Great Abaco, The Bahamas. The BRUVs also yield comparable or better results than visual surveys for non-cryptic species (Lowry et al., 2012) and longline catch per unit effort data (Brooks et al., 2011). The use of BRUVs is an appropriate method for my study because they remove behavioral effects of humans in the water and observer bias during visual surveys. The limited field of view of monoBRUVs (i.e., single camera BRUVS) can reduce the ability to detect differences in relative abundance among sites with high shark abundance, however, for sites that do not exceed a threshold of six to seven focal sharks, the limited field of view is unlikely to affect differences in detection (Kilfoil et al., 2017). Furthermore, BRUVs provide a more appropriate tool than unbaited cameras for assessing the presence and relative abundance of species at relatively low population densities which is often the case for apex predators.

\section{Methods}

Study site

The Abacos are located in the northern Bahamas and include Little Abaco, Great Abaco, and many smaller cays. The study occurred offshore of Great Abaco, the third largest island in The Bahamas, and its Atlantic-facing cays (Fig 1). Although human 
population is currently low on Abaco at 17,224 according to the All Bahamas Census 2010 Report (2012), the most recently published census, it is rapidly increasing (up $30.78 \%$ from 2000 to 2010$)$.

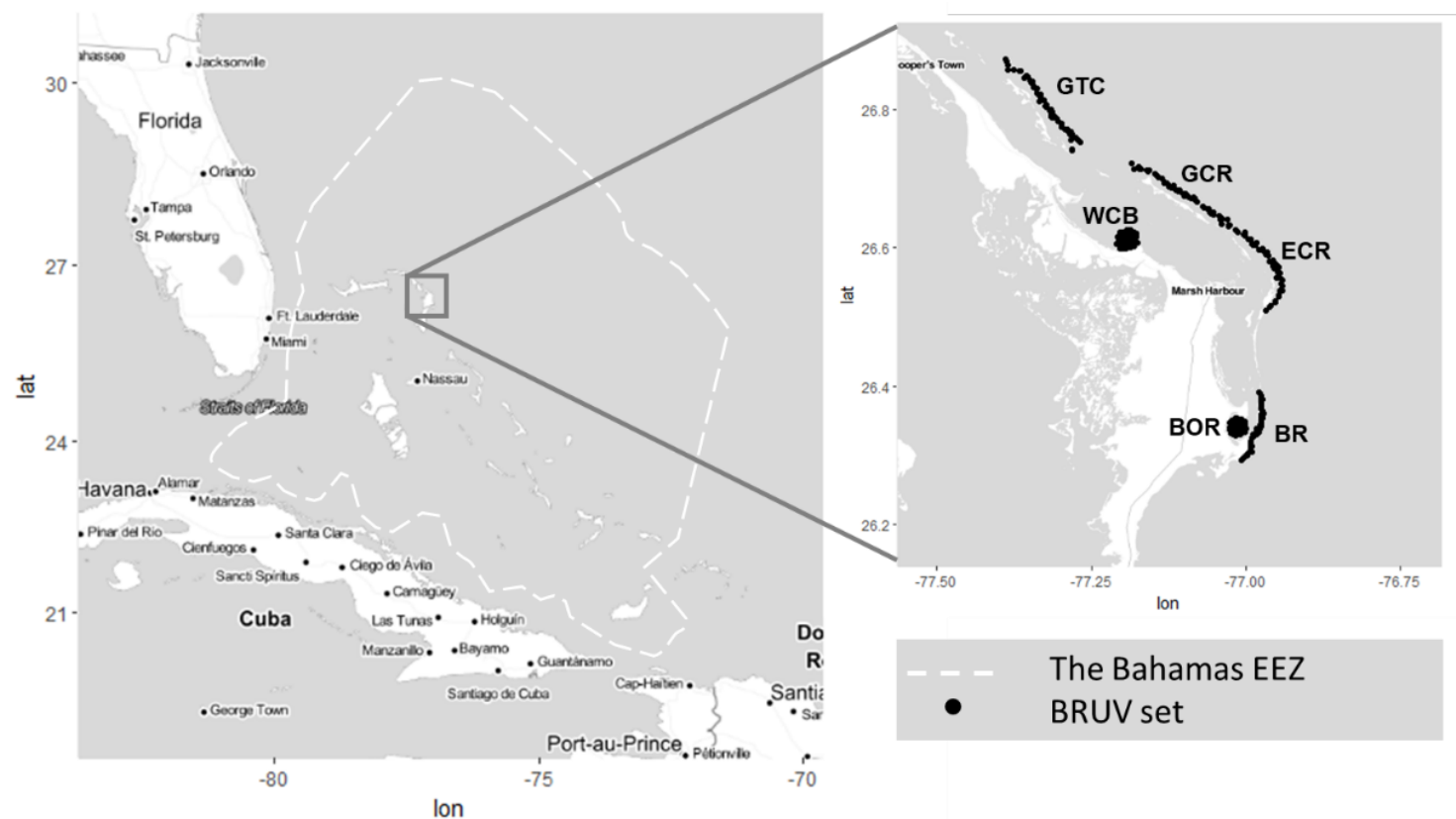

Figure 1. Map of The Bahamas shark sanctuary (left) and the study area offshore of Great Abaco (right). The white dash delineates the EEZ of The Bahamas that serves as a shark sanctuary. Individual BRUV locations are displayed with black dots in the right panel.

The coastline of Great Abaco is characterized by shallow tidal creek systems that give way to semi-enclosed, shallow ( $<1$ to $10 \mathrm{~m}$ ) bays comprising diverse habitats including patch reefs, hard-bottom and sandy-bottom interspersed within the dominant seagrass habitat (Yeager, Layman and Allgeier, 2011). The tidal creeks are lined by red dwarf mangroves (Rhizophora mangle) with some black and white mangroves (Avincennia germinans and Laguncularia racemosa, respectively) also present (Valentine-Rose et al., 2007). The most abundant seagrass in the bay and creek systems 
is Thalassia testudinum with other seagrasses (Syringodium filiforme and Halodule wrightii) and macroalgae occurring in mixed meadows and at lower densities (Chapter III). The eastern shoreline is further protected by a chain of smaller barrier islands and fringing coral reef systems.

I sampled four fringing reefs along the Atlantic-facing reef tract outside of Abaco's many Cays (Fig 1) including two northeast facing reefs [Green Turtle Cay Reef (GTC) and Guana Cay Reef (GCR)] and two east facing reefs [Elbow Cay Reef (ECR) and the Bight Reef (BR)]. I also sampled two seagrass-dominated bays: The Bight of Old Robinson (BOR) and Water Cay Lagoon (WCB). One bay site, BOR, is accessible primarily from Little Harbour, a small, isolated settlement that is currently slated for development including a 44-slip marina (Roberts, 2016, 2018). The second bay site, WCB, is the southern end of a northeast facing bight in the Sea of Abaco, and construction on a new marina and housing development on the shoreline of WCB began shortly after the sampling for this study was completed.

\section{Field methods}

The BRUV units consisted of a concrete base $(c a .12 \mathrm{~kg})$ poured into a $37-\mathrm{cm}$ diameter piling cap. Threaded rods were fitted with a series of nuts and washers that were set into the concrete. A GoPro HERO® high definition video camera was attached to a PVC coupling on a $0.91 \mathrm{~m}$ vertical rod. A buoy line was attached to an eye bolt at the top of the vertical rod. The bait cage, made from $2.54 \mathrm{~cm}$ mesh poultry fencing, was attached 
to the end of the $1.82 \mathrm{~m}$ rod that was set at an angle to position the cage in front of the camera. To keep the bait off the bottom, a PVC bipod was added to support the bait arm (Figure 2A).

All simultaneously deployed BRUVs were deployed at points haphazardly selected at least $1 \mathrm{~km}$ apart. When set for reef habitat sampling (Figure 2B), 5-10 BRUVs were recorded simultaneously along the forereef at depths of 4-17 meters. No more than 18 total BRUVs were collected in a single day. In seagrass habitats (Figure 2C), BRUV units were set at depths of 1.25-5.5 meters with a maximum of six BRUVs deployed simultaneously and no more than 12 deployed in one day.

Systems were baited with $1 \mathrm{~kg}$ of pilchard (Sardinops spp.) and positioned so the bait was downstream of the camera. All BRUVs were deployed during daylight hours (7:00 - 18:00) and retrieved after a minimum soak time of 90 minutes, with batteries providing up to $c a$. 4 hours of continuous recording. Many BRUV surveys use shorter soak times (Bond et al., 2012; Kilfoil et al., 2017). I chose to soak BRUVs for longer than standard periods, however, to increase detection probability of large-bodied species that are likely to be ecologically important (e.g., tiger sharks) and typically occur at lower abundances (Ward-Paige et al., 2010). 

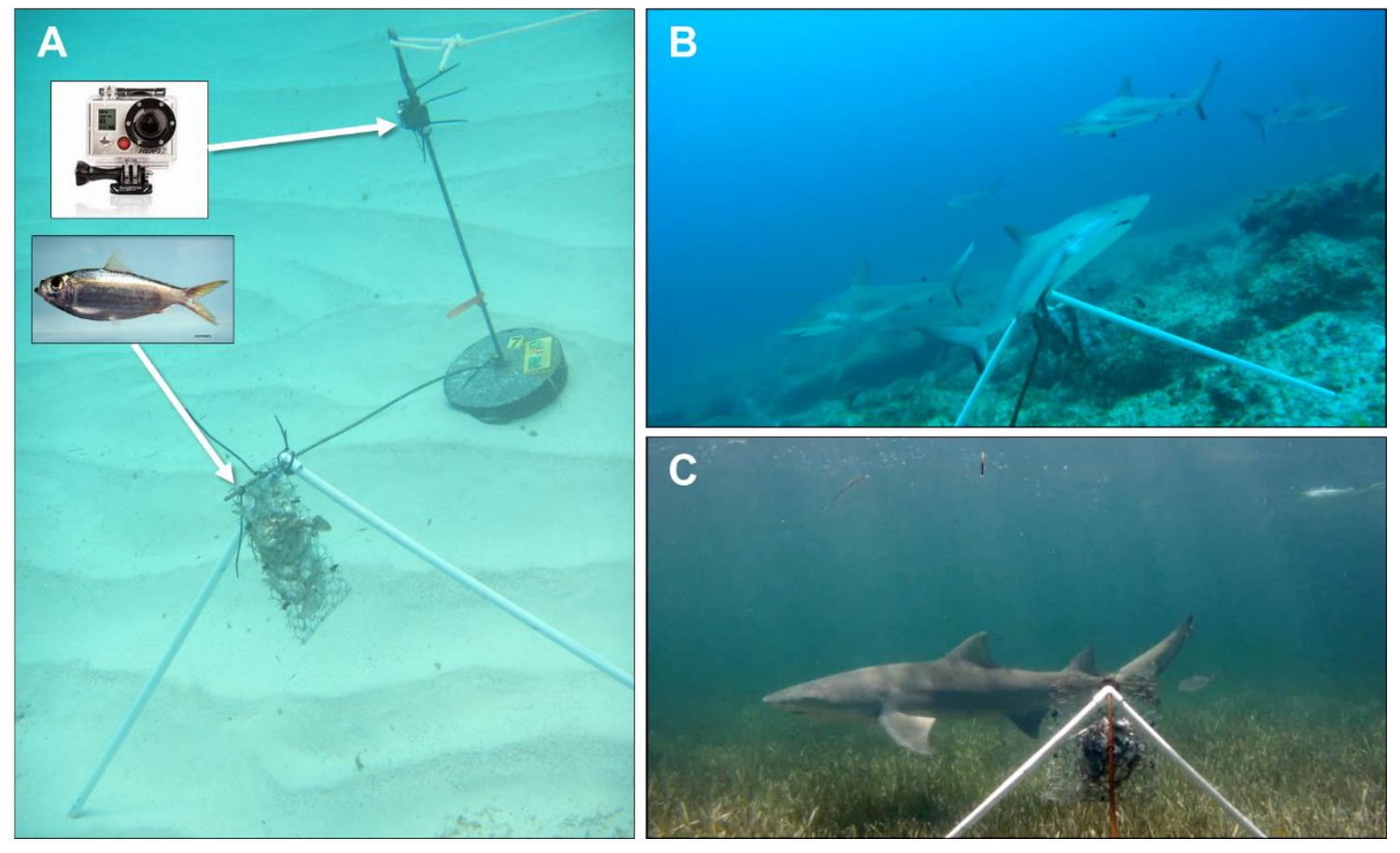

Figure 2. BRUVs (A) were set in both reef (B) and seagrass (C) habitats. We calculated $\operatorname{maxN}$ separately for each species. In B), five Caribbean reef sharks are observable while, a single lemon shark is shown in $\mathrm{C}$ )

\section{Video analysis}

Each reef BRUV was watched at normal (1x) speed and annotated independently by at least two observers, using the Global FinPrint Annotator software (www.globalfinprint.org). Because shark occurrences and relative abundances were lower in the bays than on the reefs, bay BRUVs were watched at normal (1x) speed by only one observer. Data recorded by observers included species identification and the maximum number of individuals from each species within a single frame $(\operatorname{maxN})$ (Bond et al., 2012; Lowry et al., 2012). The Annotator software captures a still image of all observations, so species identifications and count data could be verified. 


\section{Data analysis}

I used R version 3.4.1 (R Core Team, 2016) for all statistical and spatial analysis to compare data collected across the across six sites from two habitat types: reefs $(n=4)$ and two bays $(\mathrm{n}=2)$. Four metrics were used to describe relative shark abundance from individual BRUVS: $\operatorname{maxN}$, sum of maxN, presence/absence, and species richness. The $\max \mathrm{N}$ of each shark species was recorded by video observers, and the sum of $\operatorname{maxN}$ was calculated as:

$$
\max _{\text {sum }}=\sum_{i}^{n} \max N_{i}
$$

where $n$ is the total number of species observed on a BRV, and $i$ is the maxN of a species. BRUVs were assigned were assigned a score of " 1 " if present and " 0 " if absent for each species. Species richness is the total number of species observed and was calculated using the present/absent scores of all species for each BRUV:

$$
S p p_{r}=\sum_{i}^{n} p_{i}
$$

where $S p p_{r}$ is species richness, $p$ is the presence of a shark species on a BRUV, and $n$ is the total number of shark species.

To further define differences among sites and between habitat types, I used the percent of BRUVs with at least one shark observation (per species and any species):

$$
\text { Obs } \%=\frac{\sum p}{n} * 100
$$


where $O b s \%$ is the percent of BRUVS with shark observations, $p$ is the presence of a shark or species on a BRUV, and $n$ is the total number of BRUVs for a site or habitat type. I used a generalized linear model (GLM) to test the effects of habitat type (reef or bay) on occurrence (i.e., presence/absence) and $\max N$ for each species with a $\max N>1$, and the sum of maxN. Presence/absence data were analyzed using a generalized linear mixed model (GLMM) fit by maximum likelihood (Adaptive Gauss-Hermite) with link logit:

$$
\text { Species } \sim \text { habitat_type }+(1 \mid \text { site })
$$

where Species is the species of shark being modeled, habitat_type is as a fixed effect, and site is the random effect. I used Chi-square to test for differences among reef sites. Because of low counts in bay habitat, I used Fisher's Exact Test to compare bay sites.

Mean BRUV diversities were also compared among sites and between habitats using Wilcoxon Rank Sum tests. Diversity indices are described as the variance measures of species abundance distribution (Oksanen, 2018). To calculate species diversity, I used the Shannon Weiner diversity from the 'vegan’ package:

$$
H=-\sum_{i=1}^{S} p_{i} \log _{e} p_{i}
$$

where $p_{i}$ is the proportion of species $I, S$ is the number of species, and $\log _{e}$ is the natural $\log$ (Oksanen, 2018).

Rhizoprionodon spp. were not identified to the species level because of the difficulty of distinguishing between Rhizoprionodon porosus (Caribbean sharpnose 
shark) and Rhizoprionodon terraenovae (Atlantic sharpnose shark) without a physical inspection. Nine other shark observations out of a total of 629 shark observations were identifiable only to the genus level (Carcharhinus). Three of these were the only observations in their respective BRUVs, and the other six appeared at least 30 min from any other shark observation. These observations were included in calculations of overall shark occurrence and pooled maxN, however, only individuals identified to the species level (with the exception of Rhizoprionodon spp.) were included in species richness.

\section{Results}

In total, 331 BRUVs provided 815 hours of video across all sites (Table 1). Overall, there were 419 maxN observations from 9 shark species: blacknose shark (Carcharhinus acronotus), blacktip shark (Carcharhinus limbatus), Caribbean reef shark (Carcharhinus perezi), tiger shark (Galeocerdo cuvier), nurse shark (Ginglymostoma cirratum), lemon shark (Negaprion brevirostris), sharpnose shark (Rhizoprionodon spp), great hammerhead shark (Sphyrna mokarran), and bonnethead shark (Sphyrna tiburo). Sharks were present on $68.9 \%$ (228 of 331) of all BRUVs. Sharks were observed at all sites with species-level maxN values ranging from one to six (Table 1, Figure 3). Rhizoprionodon spp. and S. mokarran were only observed in reef habitat and S. tiburo was observed only in bay habitat. There was variation between habitat types in the occurrence of sharks (all species pooled: $(Z=5.787, P<0.0001)$ with at least one shark appearing on $85.2 \%$ (179 of 210) of reef BRUVs compared to $40.5 \%$ (49 of 121) of bay BRUVs. Not all species were observed equally between habitat types (Figure 4). Habitat 
type (reef or bay) had a significant effect on the occurrence of $C$. perezi $(Z=5.928, P<$ 0.0001), G. cuvier $(Z=-2.686, P=0.007)$, and $G$. cirratum $(Z=2.130, P=0.03)$ (Table 2). Two species, C. perezi and G. cirratum, were found more often at reef habitats and $G$. cuvier were observed more often in bay habitats (Figure 4, Table 2, Appendix I). Habitat type had a significant effect on maxN (reef $>$ bay) of all species pooled $(Z=5.677, P<$ $0.0001)$ and $C$. perezi $(Z=5.138, P<0.0001)$ that had the highest total sum of $\operatorname{maxN}$ at BR (Table 2).

Table 1. Summary of BRUVs. Total BRUVs only include usable BRUVs; total hours are the sum of video time analyzed; mean hours (SD) are the average length of video time analyzed per BRUV

\begin{tabular}{lccc}
\hline Site & Total Sets & Total hours & Mean hours \\
\hline Bay Total & 121 & 357.73 & $2.96 \pm 0.36$ \\
Bight of Old Robinson Bay & 61 & 182.31 & $2.99 \pm 0.30$ \\
Water Cay Bay & 60 & 175.43 & $2.92 \pm 0.42$ \\
Reef Total & 210 & 457.23 & $2.18 \pm 0.70$ \\
Bight Reef & 52 & 105.76 & $2.03 \pm 0.54$ \\
Elbow Cay Reef & 53 & 115.80 & $2.18 \pm 0.55$ \\
Green Turtle Cay Reef & 54 & 142.19 & $2.63 \pm 0.92$ \\
Guana Cay Reef & 51 & 93.49 & $1.83 \pm 0.43$ \\
Grand Total & 331 & 814.96 & $2.46 \pm 0.71$ \\
\hline
\end{tabular}




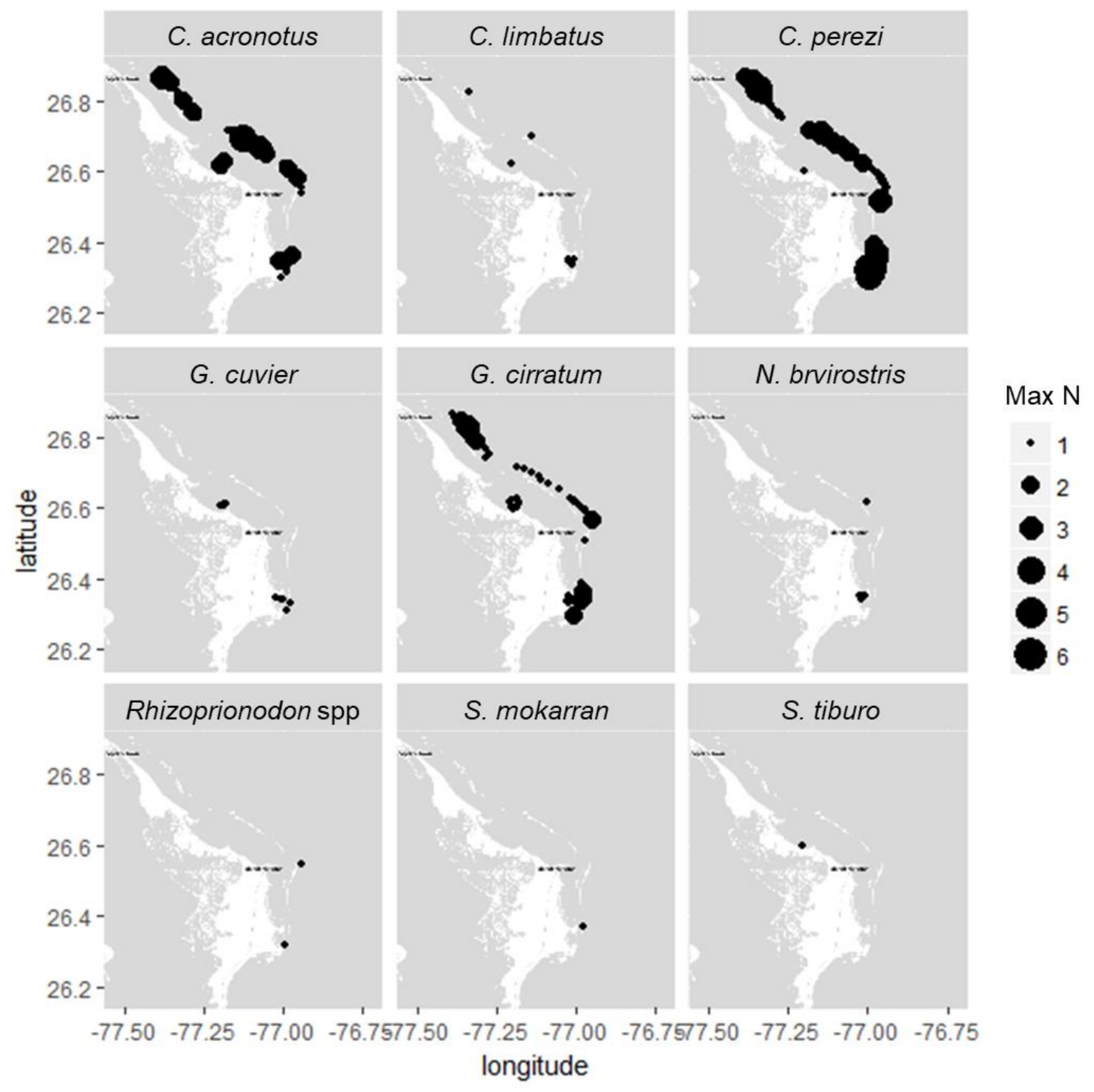

Figure 3. Location of occurrences of all shark species observed on BRUVs. The size of dots reflects $\operatorname{maxN}$ per BRUV 

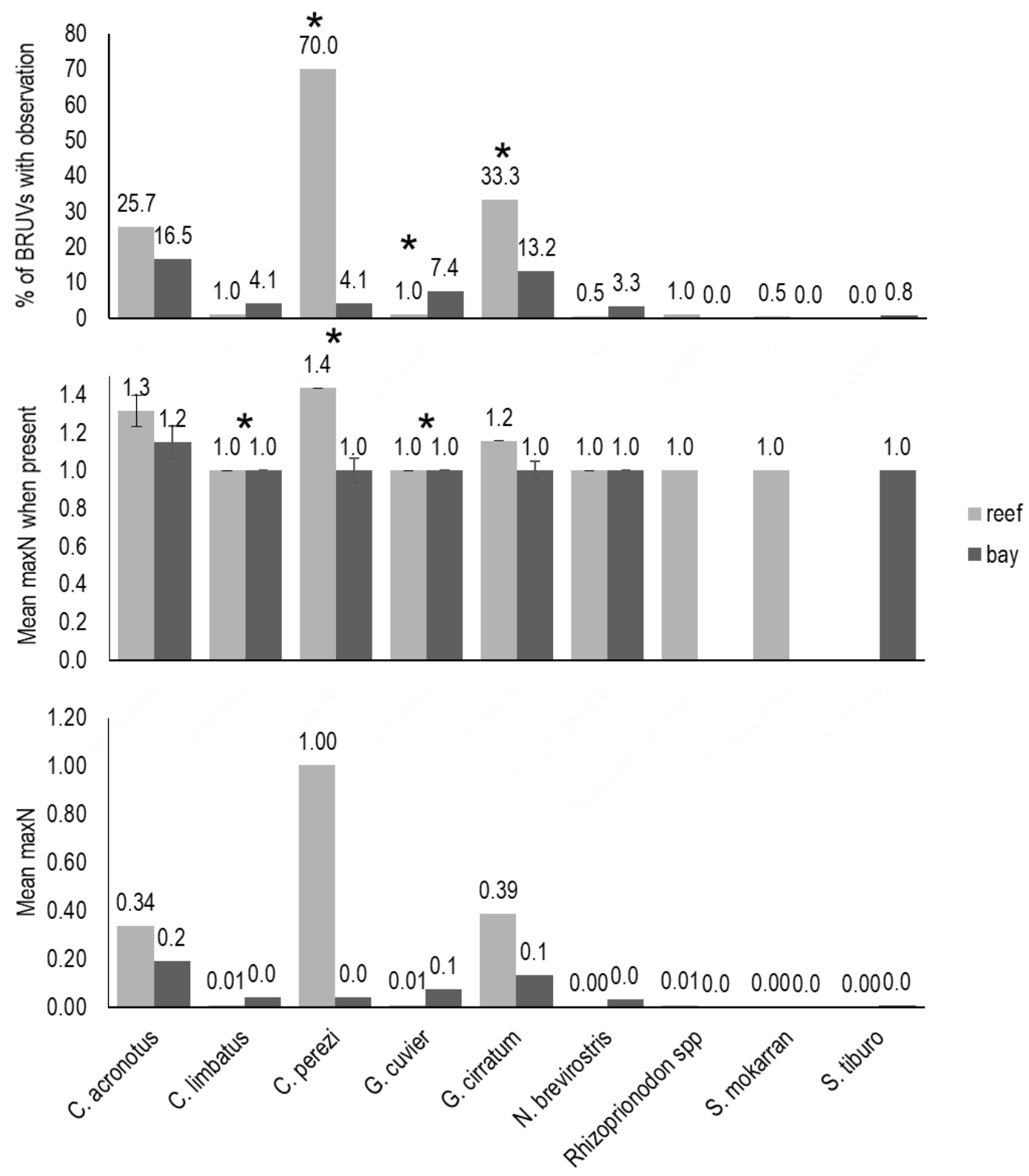

Figure 4. Species-specific occurrence and maxN across habitat types. Observations per species in reef habitat (light bars) and bay habitat (dark bars); top: percent of BRUVs with species observation; middle: mean of maxN when species is present $(\operatorname{maxN}>0)$ \pm SE; bottom: mean maxN including videos with species absent; asterisks denote significant differences in presence and absence or max $\mathrm{N}$ values between habitat types (Table 2) 
Table 2. Results of GLMM testing for differences in presence/absence and maxN between reef and bay habitats; shaded $P$ s denote significant differences between habitat types; NA signifies not enough observations for analysis

\begin{tabular}{lcccc}
\hline & \multicolumn{3}{c}{ Presence/Absence } & \multicolumn{2}{c}{ Max N } \\
\hline Sample & Z-value & $P$-value & Z-value & $P$-value \\
\hline All species & 5.787 & $<0.0001$ & 5.677 & $<0.0001$ \\
C. acronotus & 1.032 & 0.30 & -0.423 & 0.67 \\
C. limbatus & -1.776 & 0.08 & -2.573 & 0.01 \\
C. perezi & 5.928 & $<0.0001$ & 5.138 & $<0.0001$ \\
G. cuvier & -2.686 & 0.01 & -3.505 & 0.0005 \\
G. cirratum & 2.13 & 0.03 & 0.748 & 0.45 \\
N. brevirostris & -1.419 & 0.16 & -1.858 & 0.06 \\
Rhizoprionodon spp & NA & NA & NA & NA \\
S. mokarran & NA & NA & NA & NA \\
S. tiburo & NA & NA & NA & NA \\
\hline
\end{tabular}

Despite similar species richness (reef $n=8$ species, bay $n=7$ species) (Figure 5), Shannon Weiner diversity of sharks was higher in reefs $(0.36)$ than in bays $(0.10)(W=$ $3300, P=0.003)$. Within sites, $\mathrm{WCB}$ and BOR did not differ in species diversity $(W=$ $349.5, P=0.16)$. Of all sites, GTC had the highest Shannon-Weiner diversity $(0.45)$ but the lowest species richness (4), suggesting more even relative abundance across species compared to other sites. In contrast, WCB had the lowest diversity (0.10) and the highest species richness (6). This site was dominated by $C$. acronotus (sum $\operatorname{maxN}=12$ ) and $G$. cirratum ( (Figure 6). 

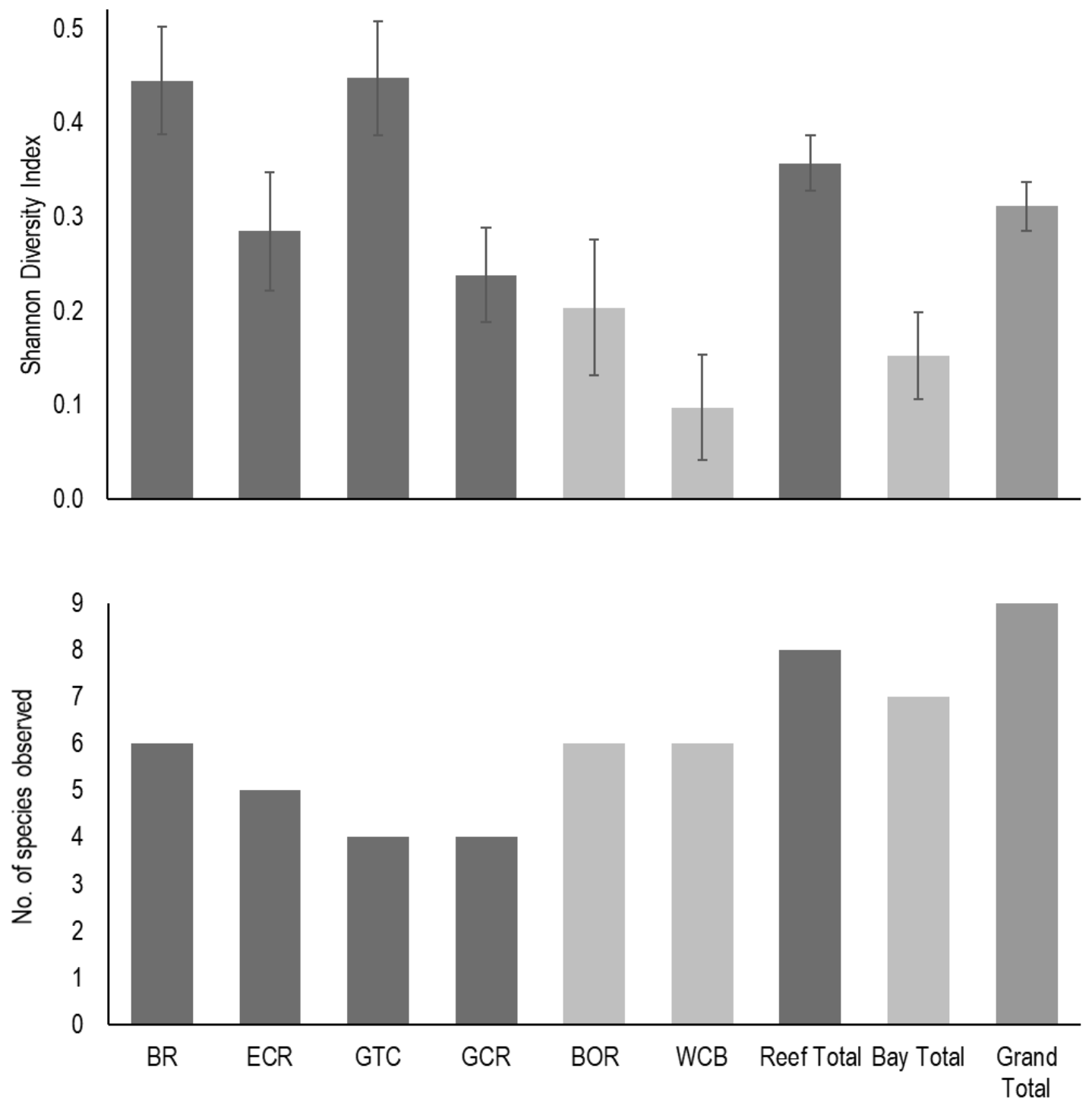

Figure 5. Mean BRUV diversity (excluding BRUVs with zero observations) and total richness of each site, habitat type and total; top: mean BRUV diversity $( \pm \mathrm{SE})$ per category; bottom: number of species observed per category (richness) 


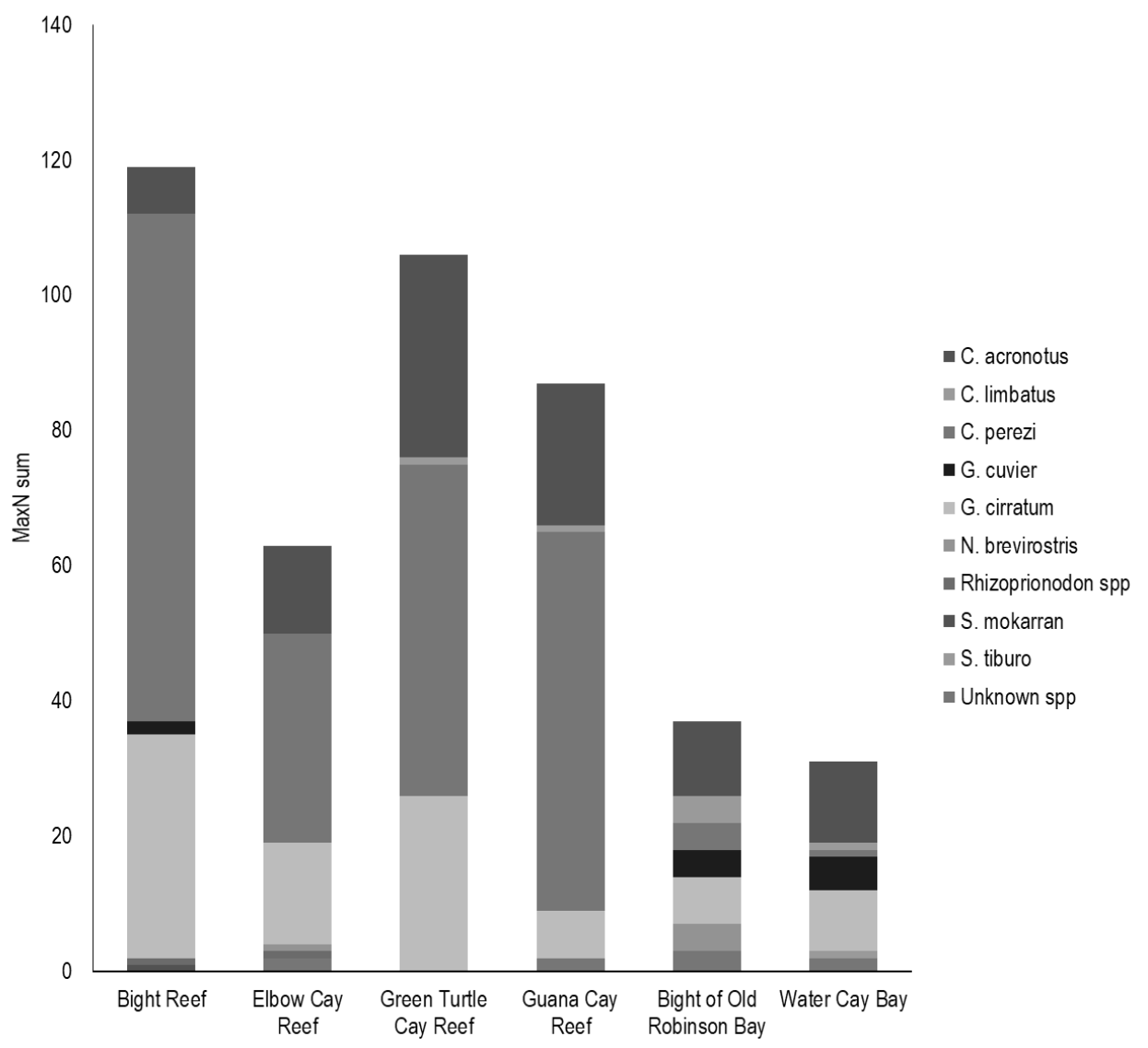

Figure 6. Total site-level sum of maxN broken down by species

I found no significant difference between the two bay sites in presence/absence $(P$ $=0.21)$, nor the sum of maxNs $(P=0.30)$ using Fisher's Exact Test. There were significant differences among reef sites in both presence/absence $\left(X^{2}=39.3, \mathrm{df}=21, P=\right.$ $0.009)$, and sum of maxNs $\left(X^{2}=53.57, \mathrm{df}=24, P=0.0005\right)$. Of the reefs, BR had the greatest and ECR the lowest sum of maxNs (total sum of maxNs $=119$ and 63, respectively; Figure 6), and GTC had the greatest and ECR the lowest observations (total observations $=83$ and 53, respectively) (see Appendix II for contingency tables). 


\section{Discussion}

The prohibition of gillnet and longline fishing has been credited for the relatively high reef-associated shark abundances in the central Bahamas (Ward-Paige et al., 2010). Still, in 2011, The Bahamas went beyond gear regulations to create a $628,026 \mathrm{~km}^{2}$, multiisland, national shark sanctuary. Even low levels of fishing mortality, however, can cause sharp declines in shark populations (Ward-Paige et al., 2010), and despite current protections, culling of large "nuisance" sharks and shark fishing still occur in the Abaco waters (pers. obs.). Despite this level of fishing, I found that shark populations off Great Abaco appear to be similar to those in other parts of The Bahamas (Brooks et al., 2011).

Shark species richness was high in both reef and seagrass-dominated bay habitats, although shark diversity and species-level occurrence differed between habitat types and even among reef sites. As highly mobile species, sharks have the ability to move among sites and habitat types, and all species observed by more than two BRUVs were observed in both reef and bay habitats (Figure 4, Appendix I). However, not all species were represented at all sites, and all species occurred at different relative abundances using the $\max N$ values. Both of these factors contributed to the observed differences in diversity among sites and habitats. Shark relative abundances are similar in the bays, but reef sites differed in the overall occurrence and concentration of sharks.

The relative abundances observed in Abaco are, in many ways, consistent with the current literature on species distributions and habitat use in other locations. Distributions of $S$. tiburo and C. limbatus are affected by factors such as water temperature, depth and distance to tidal creek inlet in Texas estuaries (Froeschke, Stunz and Wildhaber, 2010; 
Cortés et al., 2016). In Abaco, the sole observation of S. tiburo was in shallow seagrass habitat near to the coastline and tidal creeks in WCB. I observed G. cuvier significantly more often in the relatively shallow, seagrass-dominated bays than on the fringing reef. In other systems, such as Shark Bay, Australia tiger sharks also preferred shallow habitat where their prey (e.g., dugongs, sea turtles and sea snakes) are most abundant (Heithaus et al., 2002).

The species observed in this study represent diverse trophic levels including apex predators (G. cuvier and S. mokarran) and more generalist, mesopredators (e.g., C. perezi) (Bond et al., 2018). The presence of apex predators is particularly notable since they have the potential to structure populations and behaviors of prey and, ultimately, the dynamics of ecosystems. For example, the fear response elicited by encounters with an apex predator (G. cuvier, Heithaus et al., 2007) on sea turtles decreases grazing pressure on seagrasses in risky habitats. Some shark species such as $S$. mokarran also prey on large taxa and elasmobranch mesopredators (including rays) and may therefore play a similarly large role in structuring ecosystems (Heithaus et al., 2008). The singular observation of S. mokarran in Abaco was in reef habitat, but this species can occupy a large range of habitats from close inshore habitats to continental shelves offshore (Compagno, 2001). Because of the relatively low abundance of S. mokarran observed in Abaco and their susceptibility to perishing when hooked (Gallagher, Hammerschlag, Shiffman, \& Giery, 2014), further studies to determine population status and trajectories are warranted. 
Both C. perezi and G. cirratum were observed significantly more often in reef habitats than in bays, not surprisingly since they are both well known as coral-reef associated species. Their presence in bay habitats is also not surprising considering the broad ecological niche of G. cirratum (Tilley, López-Angarita and Turner, 2013) and studies suggesting $C$. perezi exerts pressure on prey from multiple trophic levels (Bond et al., 2018). Observations of $N$. brevirostris were made across habitats, but they were observed most often in BOR, the site with the most extensive tidal creek system along its coastline. Research on N. brevirostris in Bimini, The Bahamas suggests that juveniles select shallow $(<50 \mathrm{~cm})$ and warm $\left(>30^{\circ} \mathrm{C}\right)$ habitats with rocky or sandy substrate (Morrissey and Gruber, 1993; Morrissey et al., 1993), all of which can be found in the tidal creeks of BOR that may provide critical nursery habitat for juvenile $N$. brevirostris. Rhizoprionodon spp. are also known to use enclosed bays as nursery areas, but in Abaco, all observations were in reef habitat.

The significant differences observed among reef sites suggests that shark occurrence and relative abundance are affected by more than broad habitat types. On a greater-Caribbean scale, human pressures have been identified as factors leading to the broad-scale absence of reef sharks (Ward-Paige et al., 2010), but the central Bahamas was identified as one of the few locations with a high shark sighting frequency and a relatively large human population. All sites surveyed for my study in the northern Bahamas are easily accessed by small boat. The townships on Green Turtle Cay, Guana Cay, and Elbow Cay offer direct human access to GTC, GCR, and ECR. One reef site, $\mathrm{BR}$, however, is not adjacent to a human-populated cay and is nearly $20 \mathrm{~km}$ away from the Marsh Harbour, the largest township on Great Abaco. BR had the second highest 
diversity score (0.44), the highest species richness (6), and the highest sum of maxN (119) of all sites.

Reef sharks are known to have some level of site fidelity in the Caribbean (Bond et al., 2012), but they have also been observed traveling among sites up to $30 \mathrm{~km}$ apart and across deep open-water (Chapman et al., 2005). The reef tract we sampled extended more than $80 \mathrm{~km}$, but the maximum distance between adjacent reef sampling sites was 13 $\mathrm{km}$ and the maximum distance between a bay site and the nearest reef site was $9 \mathrm{~km}$. Therefore, the differences in occurrence and $\max N$ between habitat types and among reef sites are unlikely the result of movement limitations or site fidelity alone. Additional studies of interactions among shark species are needed to elucidate patterns in species richness and diversity within habitats.

The Abaco study, combined with other studies in The Bahamas, provide a baseline for future studies to measure the effectiveness of The Bahamian shark sanctuary and national management efforts. Continued monitoring will be key, and additional research is needed on the role of inter-species dynamics in distributions and abundances at multiple spatial scales.

\section{Acknowledgments}

This work was funded by Paul G. Allen Philanthropies as part of the Global FinPrint Project and a Florida International University Graduate School Data Evidence Acquisition Fellowship. I would like to thank Mark Bond and Michael Heithaus for 
guidance throughout the project, and all field assistants, particularly James Boyce,

Pamela Murata, Valeria Paz, Gina Clementi, Maximillian Theo, and The Science

Exchange interns Liberty Boyd, Ryley Parent, and Laura Thornton. I thank Sunsail and

Sailors for the Seas for providing a liveaboard vessel, personnel, and logistical support in 2015, and Friend of the Environment for their constant logistical support and resources.

Research was conducted under IACUC permit \#200508. Additional permits were provided by The Bahamas Ministry of Agriculture and Marine Resources and overseen by Bahamas National Trust.

\section{References}

Bond, M. E. et al. (2012). Reef sharks exhibit site-fidelity and higher relative abundance in marine reserves on the Mesoamerican Barrier reef, PLoS ONE, 7(3), pp. 1-14. doi: 10.1371/journal.pone.0032983.

Bond, M. E. et al. (2018). The trophic ecology of Caribbean reef sharks (Carcharhinus perezi) relative to other large teleost predators on an isolated coral atoll, Marine Biology. Springer Berlin Heidelberg, 165(4), pp. 1-13. doi: 10.1007/s00227-018$3322-2$.

Brooks, E. J. et al. (2011). Validating the use of baited remote underwater video surveys for assessing the diversity, distribution and abundance of sharks in the Bahamas, Endangered Species Research, 13(3), pp. 231-243. doi: 10.3354/esr00331.

Burkholder, D. A. et al. (2013). Patterns of top-down control in a seagrass ecosystem: could a roving apex predator induce a behaviour-mediated trophic cascade?, The Journal of animal ecology, 82(6), pp. 1192-1202. doi: 10.1111/1365-2656.12097.

Chapman, D. D. et al. (2005). Marine Reserve Design and Evaluation Using Automated Acoustic Telemetry: A Case-study Involving Coral Reef-associated Sharks in the Mesoamerican Caribbean, Marine Technology Society Journal, 39(1), pp. 42-55.

Compagno, L. J. V. (2001) Sharks of the World. An annotated and illustrated catalogue of the shark species known to date. Volume 3. Food \& Agriculture Org. 
Cortés, E. et al. (2016). Sphyrna tiburo. The IUCN Red List of Threatened Species 2016: e.T39387A2921446. http://dx.doi.org/10.2305/IUCN.UK.20162.RLTS.T39387A2921446.en. Downloaded on 11 May 2018.

Dulvy, N. K. et al. (2014). Extinction risk and conservation of the world's sharks and rays, VIMS Articles, 61(1-34). doi: 10.7554/eLife.00590.001.

Estes, J. A. et al. (2011). Trophic downgrading of planet earth, Science, 333(6040), pp. 301-307.

Estes, J. A. et al. (2016). Megafaunal Impacts on Structure and Function of Ocean Ecosystems, Annual Review of Environment and Resources. doi: 10.1146/annurev-environ-110615-085622.

Ferretti, F. et al. (2010). Patterns and ecosystem consequences of shark declines in the ocean, Ecology Letters, 13(8), pp. 1055-71. doi: 10.1111/j.14610248.2010.01489.x.

Fourqurean, J. W. et al. (2010). Effects of excluding sea turtle herbivores from a seagrass bed: Overgrazing may have led to loss of seagrass meadows in Bermuda, Marine Ecology Progress Series, 419, pp. 223-232. doi: 10.3354/meps08853.

Froeschke, J., Stunz, G. W. and Wildhaber, M. L. (2010). Environmental influences on the occurrence of coastal sharks in estuarine waters, Marine Ecology Progress Series, 407(May), pp. 279-292. doi: 10.3354/meps08546.

Gallagher, A. J. et al. (2014). Evolved for extinction: The cost and conservation implications of specialization in hammerhead sharks. BioScience, 64(7), 619-624. https://doi.org/10.1093/biosci/biu071

Hansell, A. C. et al. (2018). Local indicators of abundance and demographics for the coastal shark assemblage of Bimini, Bahamas, Fisheries Research. Elsevier, 197, pp. 34-44. doi: 10.1016/j.fishres.2017.09.016.

Heithaus, M. R. et al. (2002). Habitat use and foraging behavior of tiger sharks (Galeocerdo cuvier) in a seagrass ecosystem, Marine Biology, 140(2), pp. 237248. doi: 10.1007/s00227-001-0711-7.

Heithaus, M. R. et al. (2007). State-dependent risk-taking by green sea turtles mediates top-down effects of tiger shark intimidation in a marine ecosystem, Journal of Animal Ecology, 76(5), pp. 837-844. doi: 10.1111/j.1365-2656.2007.01260.x.

Heithaus, M. R. et al. (2008). Predicting ecological consequences of marine top predator declines, Trends in Ecology and Evolution, 23(4), pp. 202-210. doi: 10.1016/j.tree.2008.01.003. 
Heithaus, M. R., et al. (2010). Unraveling the ecological importance of elasmobranchs. In J. C. Carrier, J. A. Musick, \& M. R. Heithaus (Eds.), Sharks and their relatives II: biodiversity, adaptive physiology, and conservation (pp. 608-633). Boca Raton, FL USA: CRC Press.

Heithaus, M. R. et al. (2014). Seagrasses in the age of sea turtle conservation and shark overfishing, Frontiers in Marine Science, 1(August), pp. 1-6. doi: 10.3389/fmars.2014.00028.

Kilfoil, J. P. et al. (2017). Baited Remote Underwater Video surveys undercount sharks at high densities: Insights from full-spherical camera technologies, Marine Ecology Progress Series, 585, pp. 113-121. doi: 10.3354/meps12395.

Lowry, M. et al. (2012). Comparison of baited remote underwater video (BRUV) and underwater visual census (UVC) for assessment of artificial reefs in estuaries, Journal of Experimental Marine Biology and Ecology. 416-417, pp. 243-253. doi: 10.1016/j.jembe.2012.01.013.

Morrissey, J. F. et al. (1993). Home Range of Juvenile Lemon Sharks, Negaprion brevirostris, Copeia, 1993(2), pp. 425-434.

Morrissey, J. F. and Gruber, S. H. (1993). Habitat selection by juvenile lemon sharks, Negaprion brevirostris, Environmental Biology of Fishes, 38(4), pp. 311319. doi: 10.1007/BF00007524.

Oksanen, J. (2018). Vegan: ecological diversity, https://doi.org/10.1029/2006JF000545

R Core Team (2016). R: A language and environment for statistical computing. $\mathrm{R}$ Foundation for Statistical Computing, Vienna, Austria. URL https://www.Rproject.org/.

Roberts, T. (2016). Winding Bay says no to dredging in Little Harbour, The Abaconian.

Roberts, T. (2018). Winding Bay now owned entirely by Southworth, The Abaconian.

Shipley, O. N. et al. (2017). Fine-scale movement and activity patterns of Caribbean reef sharks (Carcharhinus perezi) in the Bahamas' Environmental Biology of Fishes. Environmental Biology of Fishes, pp. 1-8. doi: 10.1007/s10641-017-0656-4.

Tilley, A., López-Angarita, J. and Turner, J. R. (2013). Diet reconstruction and resource partitioning of a Caribbean marine mesopredator using stable isotope Bayesian modelling, PLoS ONE, 8(11), pp. 1-10. doi: 10.1371/journal.pone.0079560. 
Valentine-Rose, L. M. et al. (2007). Floral and faunal differences between fragmented and unfragmented Bahamian tidal creeks, Wetlands, 27(3), pp. 702-718. doi: 10.1672/0277-5212(2007)27[702:FAFDBF]2.0.CO;2.

Ward-Paige, C. A. (2017). A global overview of shark sanctuary regulations and their impact on shark fisheries, Marine Policy. 82(April), pp. 87-97. doi: 10.1016/j.marpol.2017.05.004.

Ward-Paige, C. a et al. (2010). Large-scale absence of sharks on reefs in the greaterCaribbean: a footprint of human pressures, PloS one, 5(8), p. e11968. doi: 10.1371/journal.pone.0011968.

Wirsing, A. J., Heithaus, M. R. and Dill, L. M. (2006). Tiger shark (Galeocerdo cuvier) abundance and growth in a subtropical embayment: Evidence from 7 years of standardized fishing effort, Marine Biology, 149(4), pp. 961-968. doi: 10.1007/s00227-006-0278-4.

Wirsing, A. J., Heithaus, M. R. and Dill, L. M. (2007). Fear factor: Do dugongs (Dugong dugon) trade food for safety from tiger sharks (Galeocerdo cuvier)?, Oecologia, 153(4), pp. 1031-1040. doi: 10.1007/s00442-007-0802-3.

Worm, B. et al. (2013). Global catches, exploitation rates, and rebuilding options for sharks, Marine Policy. Elsevier, 40, pp. 194-204. doi: 10.1016/j.marpol.2012.12.034.

Yeager, L. A., Layman, C. A. . and Allgeier, J. E. (2011). Effects of habitat heterogeneity at multiple spatial scales on fish community assembly, Oecologia, 167(1), pp. 157-68. doi: 10.1007/s00442-011-1959-3. 


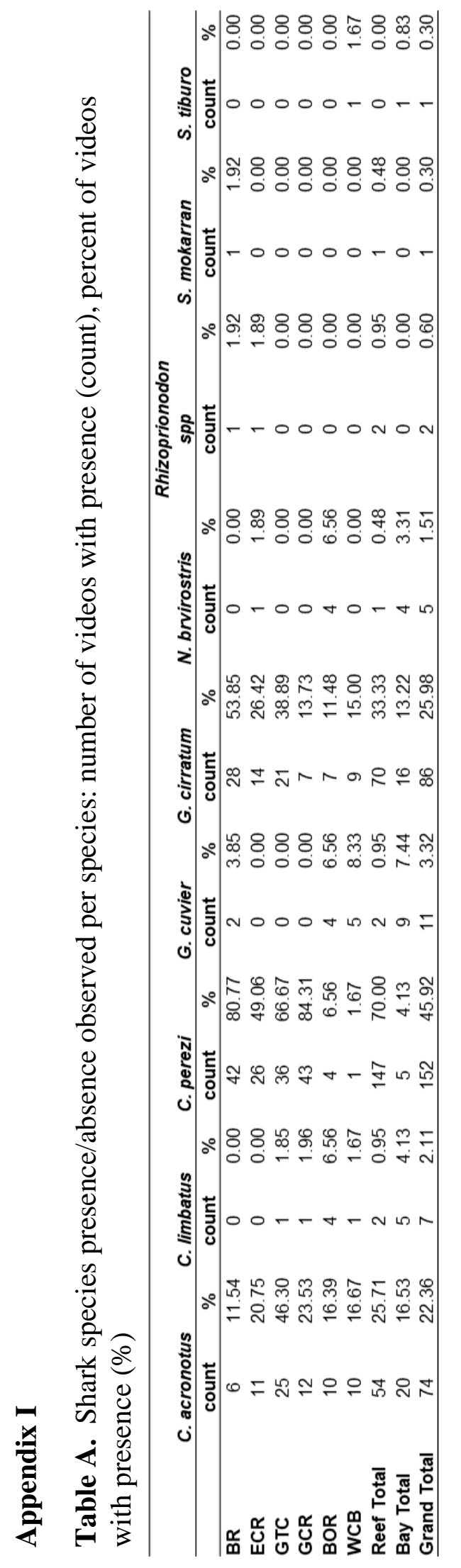


CHAPTER III

MULTI-LEVEL HABITAT SELECTION BY A LARGE MARINE HERBIVORE (CHELONIA MYDAS) IN A SHALLOW COASTAL ECOSYSTEM: THE INFLUENCE OF PREDATION RISK, FOOD ABUNDANCE, AND FORAGE NUTRIENT CONTENT 


\section{Abstract:}

Despite their potential to structure ecosystems, the factors that define habitat quality and shape habitat use of large marine herbivores remain poorly understood. In the absence of predators, foragers are predicted to be distributed across habitats proportional to the availability of food or relative to other indices of forage quality (e.g., nutrient content). However, the presence of predators can modify habitat use patterns. For example, the foraging arena hypothesis suggests that foragers may restrict their habitat use to safe arenas but select areas within these safer arenas on the basis of foraging considerations. Green turtle populations in the Caribbean have been greatly reduced by overexploitation, but many populations are now rebounding. Because they can greatly impact benthic community structure, it is important to understand the factors that shape their habitat use patterns. I used ideal free distribution (IFD) theory to develop and test $a$ priori predictions of green turtle habitat use across gradients of seagrass availability, nutrient composition, and predation risk. Within a $c a .9 \mathrm{~km}^{2}$, seagrass-dominated bay and adjacent $c a .3 \mathrm{~km}^{2}$ tidal creek area of Abaco, The Bahamas, I estimated relative predation risk and quantified food availability and quality. At the site level, green turtles did not conform to a basic IFD founded on food abundance. Green turtle densities were much lower than predicted for open habitats that had abundant seagrass, but lower $\mathrm{N}$ content in seagrass and the highest risk of encounter with predatory sharks. Turtle abundances were highest in creek habitats, where potential predators were absent. Within tidal creek habitats, green turtle distributions were positively associated with forage quality (N content) and not food abundance. Allochthonous nutrient inputs from nearby blue holes may allow seagrasses in tidal creeks to maintain high nutrient content in the face of heavy 
herbivory. Consistent with the foraging arena hypothesis, this study highlights the importance of multi-level analyses of grazer habitat use that incorporate measures of predation risk and food abundance and quality.

\section{Introduction}

Historically, habitat selection and population densities of large-bodied marine grazers (sea turtles and sea cows) have been thought to be driven exclusively by bottomup forces (Jackson, 2001). It remains unclear, however, the degree to which individuals select habitats relative to the abundance, productivity, or quality of primary producers or other factors like predation risk (e.g., Power, 1992; Massé and Côté, 2009; Shepperd et al. 2010; Wirsing, Heithaus and Dill, 2007; Heithaus et al., 2008). In terrestrial systems, forage distributions (e.g., Svalbard reindeer, Rangifer tarandus platyrhynchus, Van der Wal et al., 2000) and quality (e.g., bison, Bison bison, Seagle and Mcnaughton, 1992; ungulates, Raynor, Joern and Briggs, 2015) have significant effects on grazer habitat use and foraging behaviors. In the Serengeti, the patchy spatial distributions of grazing ungulates are attributed to heterogeneity in the nitrogen content of forage across the landscape (Seagle and Mcnaughton, 1992). In marine systems, green turtles (Chelonia mydas) and dugongs (Dugong dugon) also preferentially forage on seagrasses with high nitrogen and soluble carbohydrate content and low levels of indigestible fiber (Bjorndal, 1985; Preen, 1993; Sheppard et al., 2010). Green turtles will select for forage of relatively high nutritional value (Gilbert, 2005), possibly because nutrition of forage is positively correlated to individual growth (Bjorndal, 1982; Hadjichristophoroua and 
Grove, 1983). Other studies also consistently found dugongs over seagrass patches with high nitrogen, but when habitat choices were limited by low tides, individuals selected patches of high seagrass biomass (Sheppard et al., 2010). The foraging habitat use of some green turtle populations, including juveniles in Eleuthera, The Bahamas (Gary, 2017) and nesting females in Cyprus (Hays et al., 2002), also appears to be driven by forage availability, however, the diet composition of sea turtles is not always proportionate to the abundance of available forage species (Brand-Gardner, Lanyon and Limpus, 1999; Chapters IV and V).

Making studies of marine megagrazer habitat use especially complex is the relatively recent realization that predators (primarily large sharks) can shape the habitat use and behavior of both sea turtles (inluding adults and large juveniles; Heithaus, 2013) and sea cows (Wirsing, Heithaus and Dill, 2007). In a relatively pristine ecosystem in Shark Bay, Australia, predation risk helps shape large grazer distributions and foraging habitat use. Dugongs (Wirsing, Heithaus and Dill, 2007) and healthy green turtles (Heithaus et al. 2007) underuse high-risk habitat relative to expectations determined by habitat quality when tiger sharks (Galeocerdo cuvier) are present. Habitat use decisions, in turn, affect the structure of seagrass communities, resulting in lower seagrass biomass and altered species composition in low-risk habitats compared to high-risk ones (Burkholder et al., 2013). Indeed, it is possible that the primarily bottom-up view of megagrazer habitat use in marine ecosystems is the result of the degraded nature of large shark populations found almost worldwide (e.g., Ferretti et al., 2010). 
Understanding the role of predators and bottom-up factors in shaping habitat use decisions of large herbivores is particularly important with increasing efforts to conserve both predator and grazer populations in terrestrial and marine ecosystems. Grazers left unchecked by predation have the potential to overgraze to the point where forage species are not able to maintain themselves over time (Mysterud, 2006). The losses or reintroductions of large predators and grazers, for example, has been credited with largescale ecosystem changes (Estes et al., 2011, 2016). The reintroduction of wolves to Yellowstone National Park in 1995 and 1996, for example, has caused a shift in the behavior of their prey including elk who forego foraging in grass lands of high-quality food to forested areas that provide refuge from wolf predation (Creel et al., 2005).

Green turtles (Chelonia mydas), whose primary food source in the Caribbean is seagrass (Bjorndal, 1985), have been exploited for centuries, and their populations are probably millions of adults lower than was present historically (Jackson 1997; Jackson 2001). Such declines likely have triggered ecosystem changes and many conservation efforts have been put in place to recover sea turtle populations. In some areas, these efforts have been highly successful (e.g., Weber et al., 2014). However, in multiple ocean basins, seagrass communities have begun to collapse under heavy turtle grazing pressure where predator populations have been greatly reduced (Fourqurean et al., 2010; Christianen et al., 2014; Heithaus et al., 2014). Importantly, such declines in seagrass are not apparent in areas with large turtle populations and intact predator populations (Heithaus et al. 2014). Further studies of habitat use of sea turtles are needed from areas with relatively intact shark populations to reveal the relative importance of predation risk and foraging considerations in driving habitat use decisions. 
Theory derived from the Ideal Free Distribution (IFD; Fretwell and Lucas 1970) provides an excellent framework for investigating habitat use under spatial variation in resources and predation risk (Heithaus, Wirsing and Dill, 2012). The most basic IFD model suggests that a population's distribution among resource patches will be proportional to the available resources in each patch. In the basic IFD model, grazers would be expected to occupy all habitats if individual intake rates in high quality habitats decline with increasing occupancy to a point where it is energetically beneficial for some individuals to occupy other habitats. Deviations from a basic IFD can occur for several reasons. For herbivores, the quality of food (e.g., nutrient content) may be even more important than the rate at which energy can be harvested (Simpson et al., 2004) which could cause deviations from IFD predications determined solely by the availability of forage. Also, most species face a trade-off between foraging opportunities and risk of being killed by a predator because the most profitable habitats are often the most dangerous. In the face of an energy-risk trade-off, most individuals are willing to give up foraging opportunities or accept lower intake rates to remain in low-risk habitats (e.g., Heithaus et al., 2012). Some individuals may still use high-risk habitats, especially those in lower body condition (e.g., Serengeti wildebeest, Connochaetes taurin, Sinclair and Arcese, 1995; green turtles, Heithaus et al., 2007), because the fitness benefits of foraging in high-risk areas outweigh the potential of being killed. In some situations where risk is too high in habitats that might be profitable energetically, food-risk tradeoffs and factors influencing habitat selection may occur across a spatial hierarchy. For example, the "foraging arena hypothesis" posits that individuals will avoid high risk 
areas entirely and constrain their habitat use to safer foraging arenas where bottom-up considerations are paramount (Walters and Juanes 1993).

Here, I used IFD theory and a hierarchical framework to develop a priori predictions about how green turtles in the nearshore waters of Great Abaco, The Bahamas might distribute themselves according to spatial variation in food abundance and quality and predation risk. I used in-water surveys of seagrass abundance, seagrass nutrient content analysis, aerial video surveys of green turtles, and baited remote underwater video (BRUV) data on shark relative abundance to conduct the first explicit test of whether turtle foraging distributions in the Caribbean reflect a tradeoff between risk and energy intake or if foraging considerations alone likely determine spatial variation in turtle densities.

\section{Methods}

Study site

In The Bahamas, legal protection of sea turtles began in 2009 (S.I. 85/2009, s. 2.), and legal protection of sharks began in 2011 (S.I. No. 64 of 2011). In general, shark populations in The Bahamas are more intact than other locations in the Caribbean (Chapter II, Ward-Paige et al. 2010) making it a regionally important location to investigate green turtle habitat use under potential predation threat.

The study took place offshore of Great Abaco, The Bahamas. Abaco is located in the northern Bahamas and comprises Great Abaco, Little Abaco, and many smaller Cays. 
Great Abaco, the largest of the Abacos (Figure 1), is characterized by shallow tidal creek systems and sheltered bays supporting multiple tropical marine ecosystems including coral reef, hardbottom, rocky shoreline, mangrove, and seagrass ecosystems. Its eastern shoreline is further protected by a chain of smaller barrier islands and fringing reef systems. The seagrass-dominated system, with a maximum tidal range of $1.3 \mathrm{~m}$, hosts the three most common Caribbean seagrass species: Thalassia testudinum, Syringodium filiforme, and Halodule wrightii. The most common species found in the waters of Abaco is T. testudinum, turtle grass. Abaco is within the geographic range of five sea turtle species including the three most common species in the Caribbean: green (Chelonia mydas), loggerhead (Caretta caretta), and hawksbill (Eretmochelys imbricata) turtles. Large-bodied sharks that may pose a risk to sea turtles are also found in coral reef and bay habitats around Abaco including tiger sharks (Galeocerdo cuvier) (Chapter II).

The study took place in the Bight of Old Robinson (BOR), a ca. $9 \mathrm{~km}^{2}$, seagrassdominated bay on the eastern coastline of Great Abaco (see Chapter II for a detailed description), (Figure 1), and the $c a .3 \mathrm{~km}^{2}$ adjacent tidal creeks. The tidal creeks are uninhabited watersheds with relatively little human impact (Stoner et al., 2011). Tidal creeks and bays in The Bahamas are typically oligotrophic (Allgeier, 2010), but the 18 marine blue holes (underwater caves) found in the tidal creeks adjacent to the Bight of Old Robinson may be a source of nutrients to the system (Lapointe et al., 2004). The maximum depth of the sampling area, near the mouth of BOR, was $c a .6 \mathrm{~m}$ and the minimum sampled was $c a .0 .3 \mathrm{~m}$. 


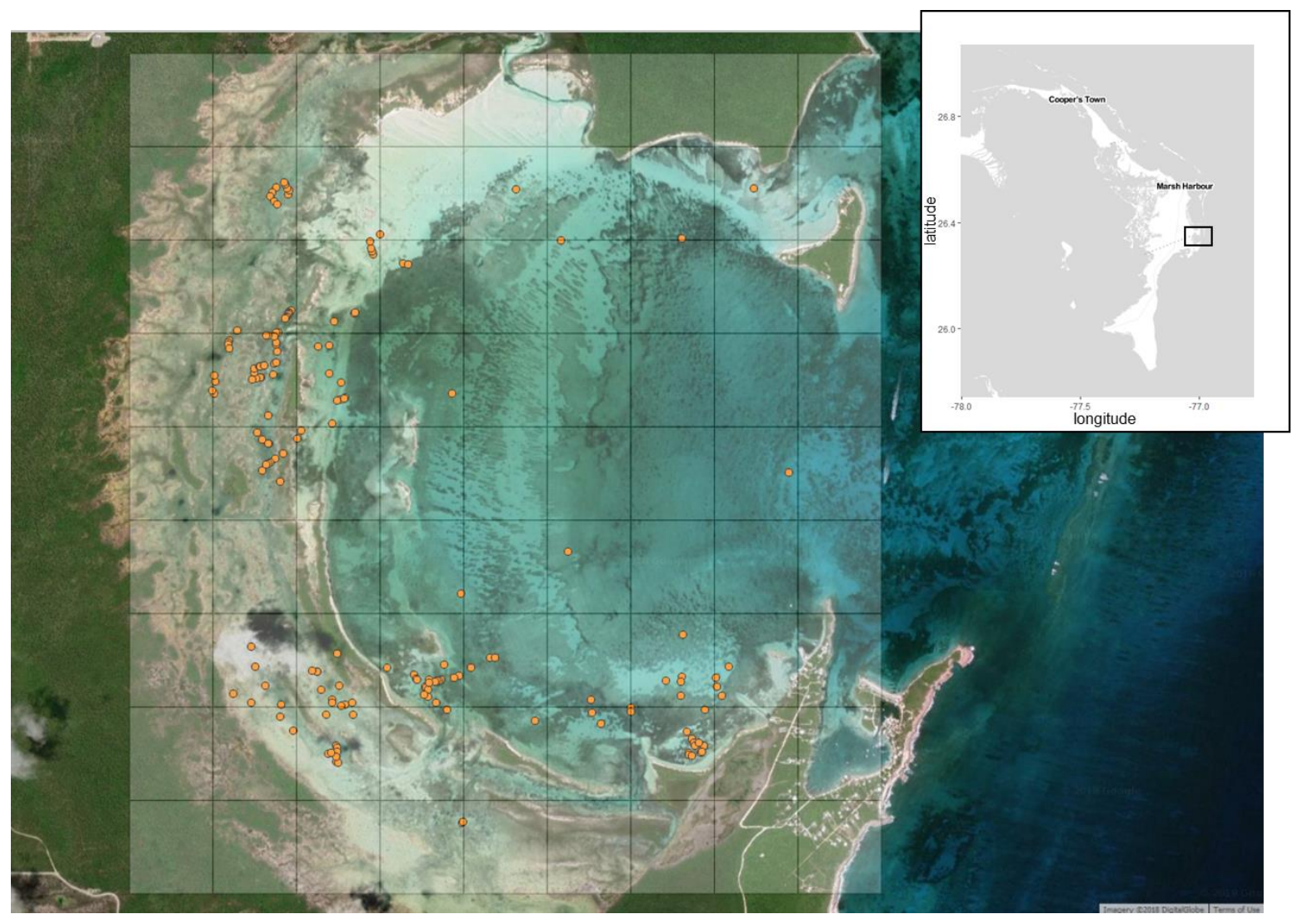

Figure 1. Bight of Old Robinson, along the east coast of Great Abaco (inset). The grid divides the bay into $500 \mathrm{~m}$ x $500 \mathrm{~m}$ cells. Orange dots are turtle sightings.

Green turtles are the most abundant species along the eastern coastline of Great Abaco. Out of 99 individuals captured opportunistically during the summers of 20132017,89 were green turtles ranging in size from 26 to $71 \mathrm{~cm}$ minimum curved carapace length. Of these, $17.9 \%$ (16 of the 89 ) had recent injuries or scars (Figure 2) or missing limbs (pers. obs.). 

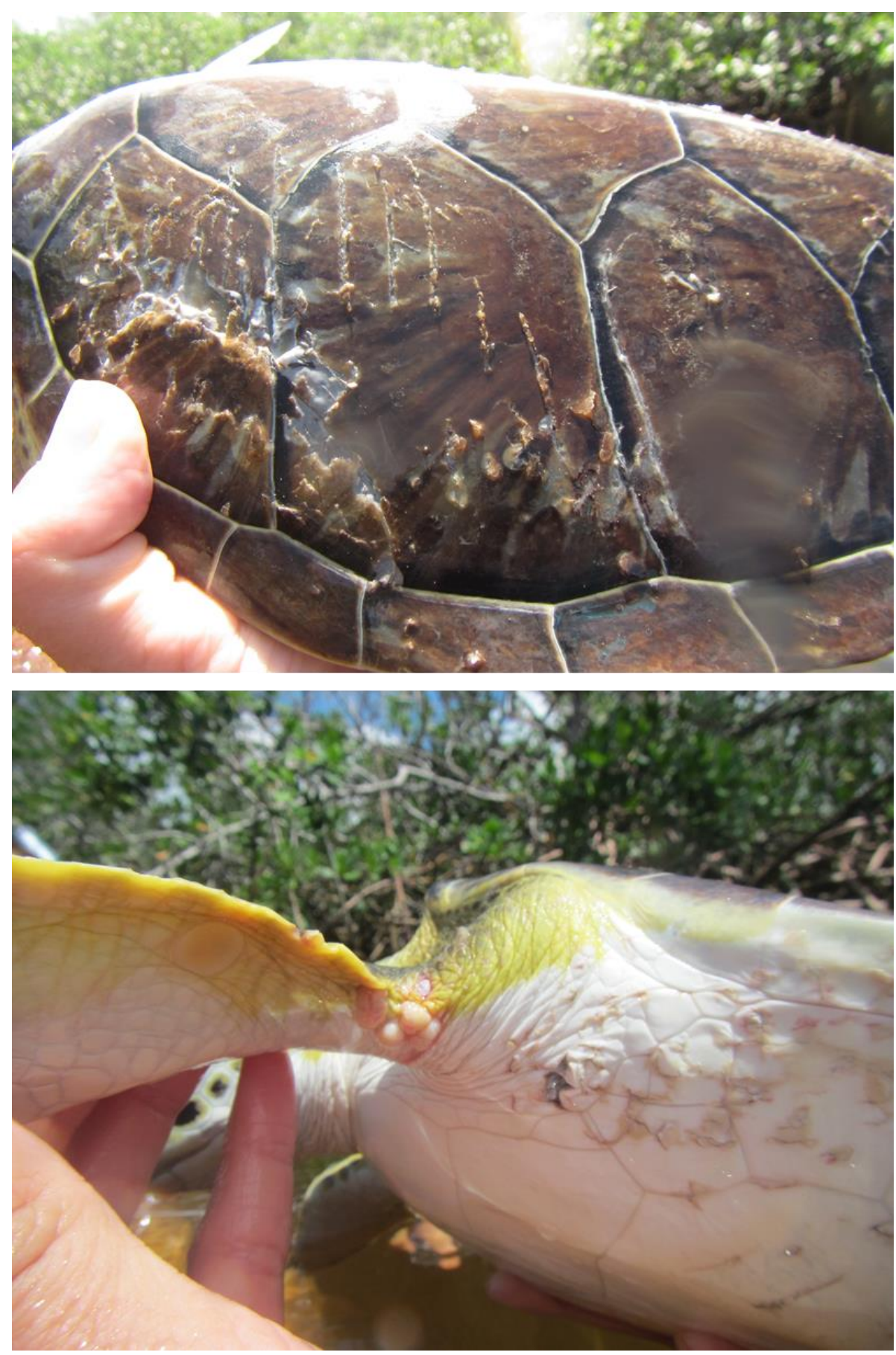

Figure 2. Green turtle captured in a tidal creek north of the Bight of Old Robinson. The scratches and puncture marks on the carapace, plastron, and soft tissue are potential evidence of shark inflicted injuries. 


\section{Habitat categorization}

I divided the study area into $500 \mathrm{~m}$ x $500 \mathrm{~m}$ cells that featured waters deep enough for turtles to occupy (Figure 1) using a vector grid layer in QGIS version 2.18.11 (QGIS Development Team, 2018). The $0.25 \mathrm{~km}^{2}$ resolution results in cells that are relatively homogenous with respect to habitat type (e.g., tidal creek, nearshore, open water). All grid cells were assigned to one of three habitat types (Figure 3). Creeks ( $\mathrm{n}=$ 14 cells) contained tidal creeks and inlets, nearshore habitat $(n=23$ cells $)$ were adjacent to shore had water depths less than $2 \mathrm{~m}$, and open habitats $(\mathrm{n}=19$ cells $)$ were farther from shore and $>2 \mathrm{~m}$ average depth with the exception of the cells at the mouth of the bay. These cells were close to land but featured water depths and benthic habitats more similar to other open habitats than nearshore ones. Using the "join attributes" function in QGIS, I extracted all survey data (i.e., drone, seagrass and BRUV surveys) per cell. 


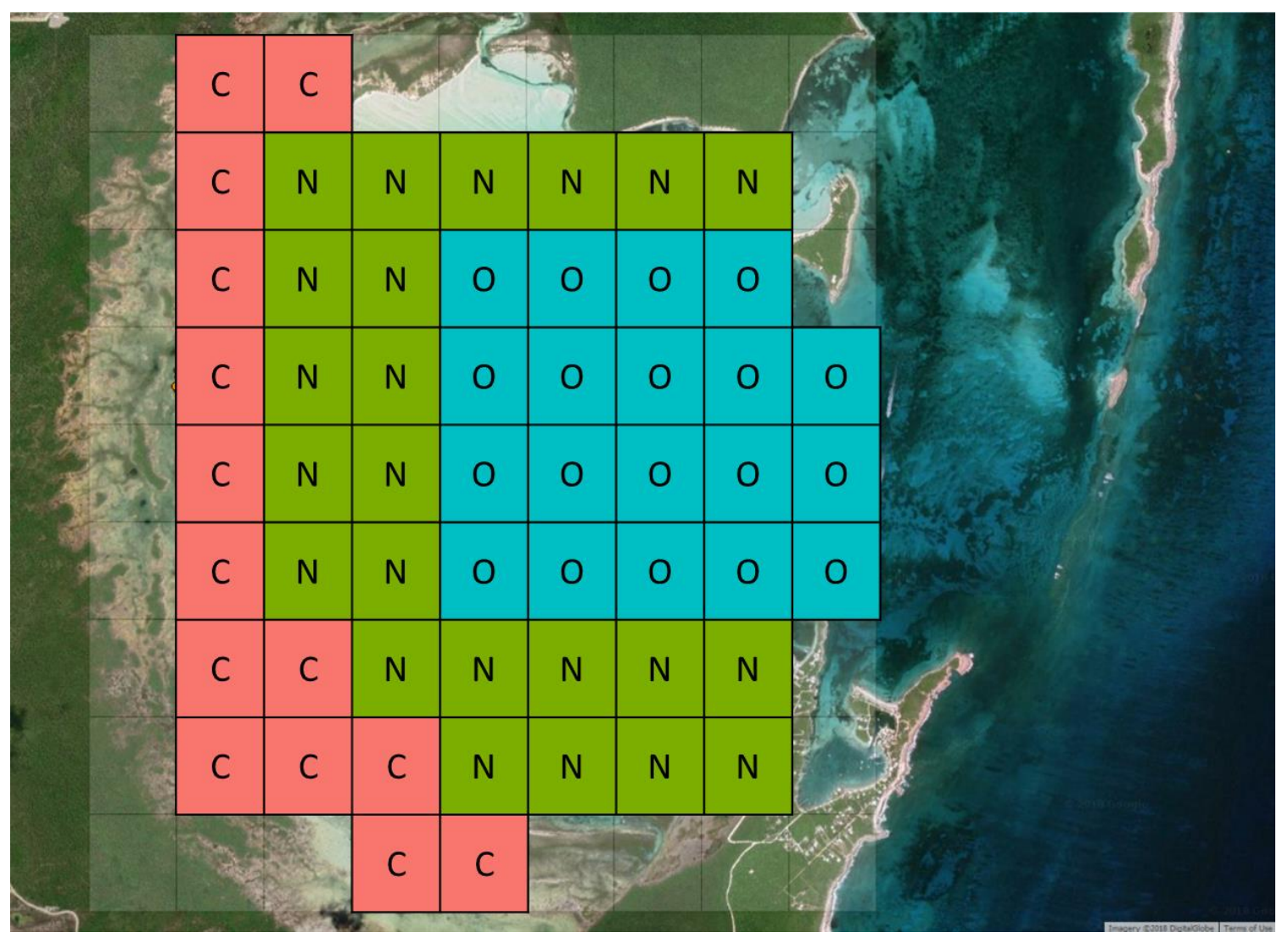

Figure 3. Habitat assignments of cells within the study area. $\mathrm{C}=$ creek (pink), $\mathrm{N}=$ nearshore (green), and $\mathrm{O}=$ open (blue). Cells not included in study are uncolored.

\section{Forage availability}

I assessed macrophyte abundance and community composition from randomly selected points from each drone flight path for a total of 131 survey points across habitat types. The random survey points fell within 9 creek habitat cells, 23 nearshore habitat cells, and 18 open water habitat cells. At each point, I estimated the abundance of each macrophyte species within four, $0.25 \mathrm{~m}^{2}$ quadrats using an adaptation of the BraunBlanquet scale for rapid vegetation assessments (Braun-Blanquet, 1932, 1964). The Braun-Blanquet method, commonly used to assess the abundance of seagrass and 
macroalgae, is efficient, highly repeatable, and minimizes observer differences

(Fourqurean et al., 2001). Within each plot, two observers independently assigned scores (Table 1) for each seagrass species within each of two quadrats each, and the mean of the four scores was used for analysis (Fourqurean et al., 2001).

Table 1. Braun-Blanquet density scores (Fourqurean et al., 2001)

\begin{tabular}{ll}
\hline Score & Cover \\
\hline 0 & Taxa absent from quadrat \\
0.1 & Taxa represented by a solitary shoot, $<5 \%$ cover \\
0.5 & Taxa represented by a few $(<5)$ shoots, $<5 \%$ cover \\
1 & Taxa represented by many $(>5)$ shoots, $<5 \%$ cover \\
2 & Taxa represented by many $(>5)$ shoots, $5-25 \%$ cover \\
3 & Taxa represented by many $(>5)$ shoots, $25-50 \%$ cover \\
4 & Taxa represented by many $(>5)$ shoots, $50-75 \%$ cover \\
5 & Taxa represented by many $(>5)$ shoots, $75-100 \%$ cover \\
\hline
\end{tabular}

\section{Forage nutrient content}

Five T. testudinum short shoots (i.e., bundles of leaves growing vertically upwards from the rhizome composing the above ground biomass) were collected from within or nearby the quadrat sampling points (where seagrass occurred) for nutrient content analysis. Seagrass was not found at all random survey points, so seagrass was collected from 7 creek habitat cells, 22 nearshore habitat cells, and 17 open water habitat cells. T. testudinum was selected because it is the primary component of green turtle diets in the Greater Caribbean (Bjorndal, 1997) and it was the only seagrass found at the majority $(85.5 \%)$ of our sampling plots. Furthermore, comparisons of nutrient content 
within a species is most useful for assessing spatial variation in nutrient content overall (Duarte, 1990) and T. testudinum is commonly used to assess nutrient content at this study site (Allgeier, Rosemond and Layman, 2011; Yeager, Acevedo and Layman, 2012) and other Abaco seagrass habitats (Stoner et al., 2014). The seagrass samples were scraped free of epiphytes, dried in a food-grade dehydrator, ground to a fine powder with a mortar and pestle, and transported to Florida International University for nutrient content analysis. Total $\mathrm{C}$ and $\mathrm{N}$ content of seagrass biomass from each sampling point were quantified using a CE Flash 1112 elemental analyzer using standard procedures. Total P was analyzed colorimetrically following modified methods from Solorzano and Sharp (1980) on a Shimadzu UV-2101PC spectrophotometer.

\section{Predator relative abundance}

To estimate spatial variation in predation risk, I deployed 61 baited remote underwater video (BRUV) cameras between July and August of 2016. Each BRUV camera deployment included one $\mathrm{kg}$ of oily fish in bait cages positioned downstream of a high definition video camera on threaded rods attached to a $37 \mathrm{~cm}$ diameter concrete base (c.a. $12 \mathrm{~kg}$ ). All simultaneously deployed BRUVs were deployed at least $1 \mathrm{~km}$ apart and set at depths of 1.25-5.5 meters. No more than six BRUVs were deployed simultaneously and no more than 12 were deployed in one day. Each deployment lasted $3-4 \mathrm{hrs}$. Extremely shallow water depths precluded deployments of standard BRUV equipment in the creeks, but these waters are inaccessible to potential sea turtle predators (none were observed during drone flights in these habitats). To test this assumption, I deployed 
modified BRUVs (camera and $c a .1 \mathrm{~kg}$ of bait on adjacent cinder blocks) nine times during the summer of 2018.

Each video was watched at normal (1x) speed by at least one observer and annotated using the Global FinPrint Annotator software (http://globalfinprint.org/). Data recorded by observers included species identification and the maximum number (maxN) of individuals from each species within a single frame (Bond et al., 2012; Lowry et al., 2012). The annotation software captures a still image and an eight second video clip whenever a shark is recorded in frame, allowing verification of species identity and counts data.

\section{Turtle abundance and distributions}

To determine turtle densities, I used a DJI Phantom 3 Advanced quadcopter drone, equipped with a high definition video camera and controlled through an iPad Mini 4 and remote control. Drones are increasingly being used in marine system studies (e.g., Kiszka et al., 2016; Rees et al., 2017) because they can reduce field time and costs and provide access to otherwise inaccessible or dangerous habitats. Critical for this study was 1) the ability to survey turtles that may be especially sensitive to human disturbance because of the less than a decade old ban on turtle harvesting and 2) to be able to survey turtles at all depths of the water column due to the clarity of the water and shallow depths throughout the study area. 
For my study, the drone was recalibrated daily at sea level to ensure precise flight data and launched under manual control from a $5 \mathrm{~m}$ long outboard motor boat. After launching, flight mode was switched to autonomous flight through the Hangar Autopilot $(\mathcal{C}$ application. Flights were pre-programmed to occur at an altitude of $10 \mathrm{~m}$ above the water's surface along predetermined paths connecting points determined by a random point generator (http://www.geomidpoint.com/random/). In the rare cases when Australian pine (Casuarina spp) growing on rocky cays posed potential obstacles to the flight path, transects were flown at $15 \mathrm{~m}$ and the transect area adjusted using the increased field of view for analysis. The land area in the creek and nearshore habitats reduced the survey area. The length of each transect (distance flown) varied by the distance between random points and was restricted by battery life ( $c a .18$ min flight time). Transects were selected using random number assignments each day, with no more than eight transects flown per day, and no consecutive flights were flown within any one cell. Given that the survey area is relatively sheltered from wind, turbidity is minimal, and a polarized filter for the camera minimized glare, the probability of missing individuals is extremely low (Figure 4). Furthermore, perception bias was minimized by only flying when Beaufort Sea state and wind scales were $\leq 2$, when glare could be minimized to $<20 \%$ of the field of view, and when water clarity allowed easy viewing of the bottom at the greatest study area depths. 

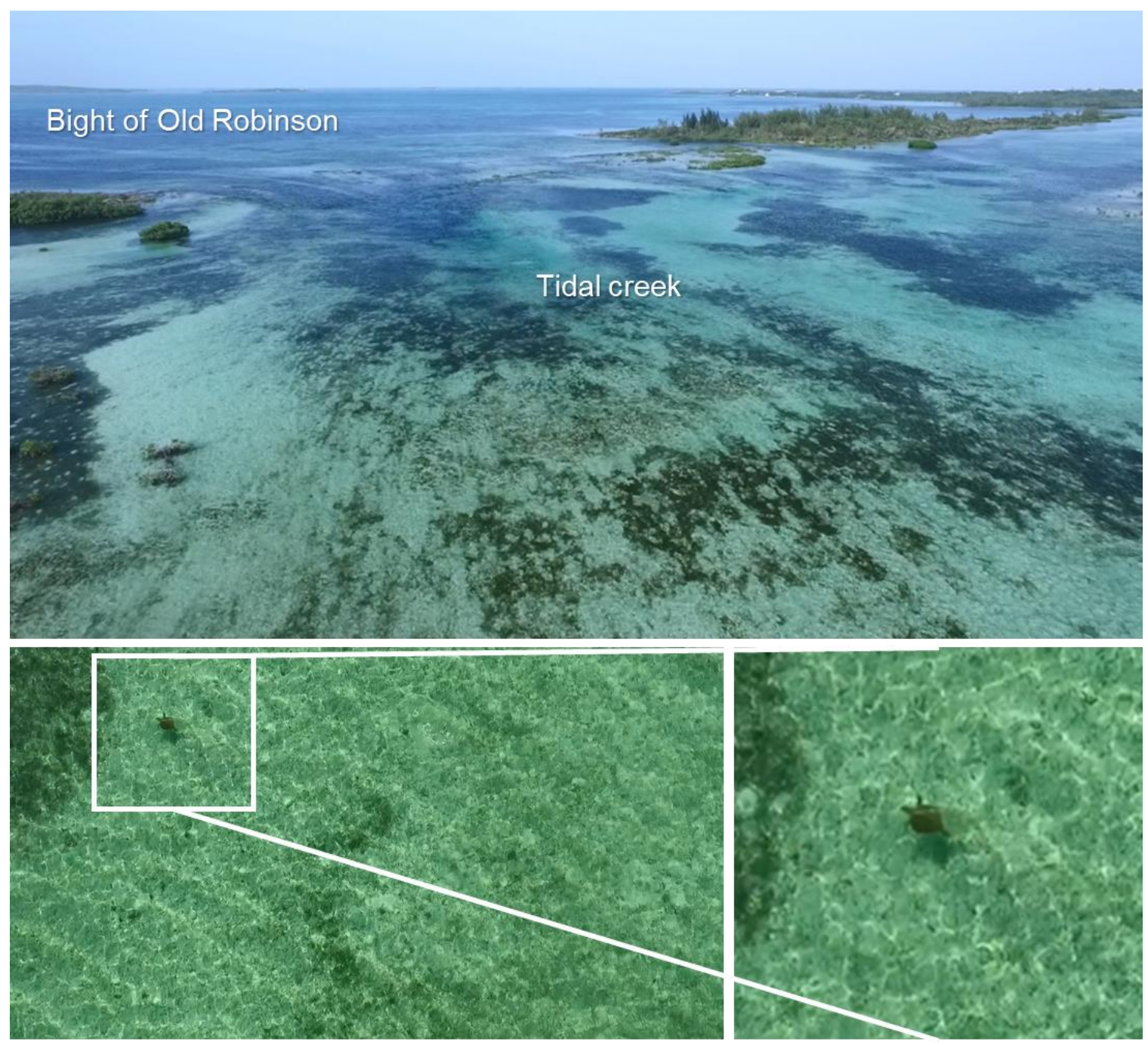

Figure 4. Still frames from drone video taken by DJI Phantom 3 Advanced; Top: view from the tidal creeks looking into the Bight of Old Robinson; Bottom: turtle sighting during drone transect in tidal creek with full field of view (left) and magnified (right)

One observer viewed each video for turtle sightings, number of individuals present at each sighting, and the video timestamp. Sightings were verified by a second observer. Flight data extracted through AirData UAV, Inc. were matched to the video timestamp to determine sighting location and to calculate transect area:

$$
T_{\text {area }}=\tan \theta * a * 2 * l
$$


where $T_{\text {area }}$ is the transect area in $\mathrm{m}^{2}, \theta=81.7^{\circ}$ is the camera's horizontal field of view calculated using the reported $94^{\circ}$ diagonal field of view (DJI, 2015), $a$ is the altitude or distance from the water to the camera in meters, and $l$ is the total transect length in meters. Results of field of view calculations were compared to calculations based on visual measurements from five videos where the boat was clearly visible and within frame. Using the known width of the boat stern I found the horizontal field of view to use in the $T_{\text {area }}$ calculation. The empirically tested width of the field of view was $0.19 \mathrm{~m} \pm$ $0.58 \mathrm{SD}$ smaller than the calculated values with a range of -0.87 to $0.65 \mathrm{~m}$. Turtles observed during manual flight when altitudes exceeded $15 \mathrm{~m}$ were not included in the analysis. Turtle sighting density was calculated by dividing the number of turtles sighted transect ${ }^{-1}$ cell $^{-1}$ by the transect area transect ${ }^{-1}$ cell $^{-1}$, and the mean sighting density per cell was used in analyses.

\section{Data analysis}

I used R software (R Core Team, 2016) to run all statistical tests. Logistic regression was used to test for differences in tiger shark observations among habitats. I used a Wilcoxon rank sum test to explore differences in the distributions between habitat types of turtle sighting density, nutrient content and macrophyte abundances. Mean turtle density per cell was calculated by taking the mean turtle density (number of animals sighted by the transect area surveyed) of all transect segments within a cell. A generalized linear mixed effects model from R Package 'lme4' was used to test for relationships between turtle sightings counts, with a Poisson distribution, and habitat 
variables with habitat type set as the random intercept and effort (log(area surveyed)) as the model offset (a comparison to linear mixed effects models using turtle sighting density [sightings/survey area] as the response variable and with Satterthwaite's degrees of freedom in the R Package 'ImerTest' can be found in Appendix I). Survey area was converted to hectares prior to model selection. I used a model selection table created using the R Package 'AICcmodavg' (function = aictab, Mazerolle, 2017) for stepwise model selection using Akaike information criterion (AIC) and Akaike weights. Models that did not converge were not included in the selection, and the model with the lowest AIC score was selected to describe the data.

\section{Results}

Forage availability

Seagrass abundance (Braun-blanquet scores) and composition varied across habitats (Table 2). The abundance of T. testudinum, the most abundant species overall (Figure 5), was significantly greater in open habitat $(W=20.5, P=0.02)$ than creek habitat but was not significantly different between creek and nearshore $(W=72, P=$ $0.19)$ nor between nearshore and open habitats $(W=269, P=0.11)$. The seagrass $S$. filiforme was significantly greater in open habitat than creek habitat $(W=16, P=$ $0.0006)$ and nearshore habitat $(W=325, P=0.002)$ and greater in nearshore than creek $(W=62, P=0.048)$. Another seagrass, $H$. wrightii abundance was significantly greater in the creek habitat than nearshore $(W=168, P=0.004)$ and open $(W=134, P=0.005)$, but not significantly different between nearshore and open habitats $(W=208, P=1.00)$. 
Total seagrass abundance significantly was significantly greater in open habitat than nearshore $(W=291, P=0.03)$ but did not differ between creek and nearshore $(W=$ $106.5, P=0.92)$ nor creek and open $(W=46, P=0.08)$. Total algae did not significantly differ across habitats (Figure 6).

Table 2. Wilcoxon rank sum test results of turtle sighting density and habitat variables between habitats; Significance codes: 0

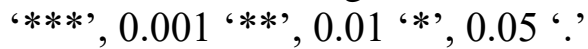

\begin{tabular}{|c|c|c|c|c|}
\hline Variable & Habitat 1 & Jabitat 2 & $W$ & $P$-value \\
\hline Turtles/ha & creek & near & 204 & 0.0223 \\
\hline Turtles/ha & creek & open & 206 & 0.0000 \\
\hline Turtles/ha & open & near & 75 & 0.0001 \\
\hline Depth & creek & near & 29 & 0.0189 \\
\hline Depth & creek & open & 0 & 0.0002 \\
\hline Depth & open & near & 370 & 0.0000 \\
\hline Tt & creek & near & 72 & 0.1936 \\
\hline $\mathrm{Tt}$ & creek & open & 20.5 & 0.0020 \\
\hline $\mathrm{Tt}$ & open & near & 269 & 0.1059 \\
\hline $\mathrm{Hw}$ & creek & near & 168 & 0.0044 \\
\hline $\mathrm{Hw}$ & creek & open & 134 & 0.0045 \\
\hline $\mathrm{Hw}$ & open & near & 208 & 1.0000 \\
\hline$S f$ & creek & near & 62 & 0.0480 \\
\hline $\mathrm{Sf}$ & creek & open & 16 & 0.0006 \\
\hline Sf & open & near & 325 & 0.0016 \\
\hline Algae & creek & near & 142 & 0.1159 \\
\hline Algae & creek & open & 101 & 0.3158 \\
\hline Algae & open & near & 276 & 0.0740 \\
\hline $\mathrm{N}$ & creek & near & 145 & 0.0001 \\
\hline $\mathrm{N}$ & creek & open & 119 & 0.0000 \\
\hline $\mathrm{N}$ & open & near & 48 & 0.0000 \\
\hline$P$ & creek & near & 129 & 0.0064 \\
\hline$P$ & creek & open & 88 & 0.0749 \\
\hline$P$ & open & near & 226 & 0.2791 \\
\hline C & creek & near & 116 & 0.0481 \\
\hline C & creek & open & 87 & 0.0866 \\
\hline C & open & near & 214 & 0.4574 \\
\hline $\mathrm{CN}$ & creek & near & 9 & 0.0001 \\
\hline $\mathrm{CN}$ & creek & open & 0 & 0.0000 \\
\hline $\mathrm{CN}$ & open & near & 338 & 0.0000 \\
\hline NP & creek & near & 80 & 0.9010 \\
\hline NP & creek & open & 86 & 0.0995 \\
\hline NP & open & near & 97 & 0.0101 \\
\hline $\mathrm{CP}$ & creek & near & 31 & 0.0178 \\
\hline $\mathrm{CP}$ & creek & open & 33 & 0.0995 \\
\hline $\mathrm{CP}$ & open & near & 146 & 0.2546 \\
\hline
\end{tabular}



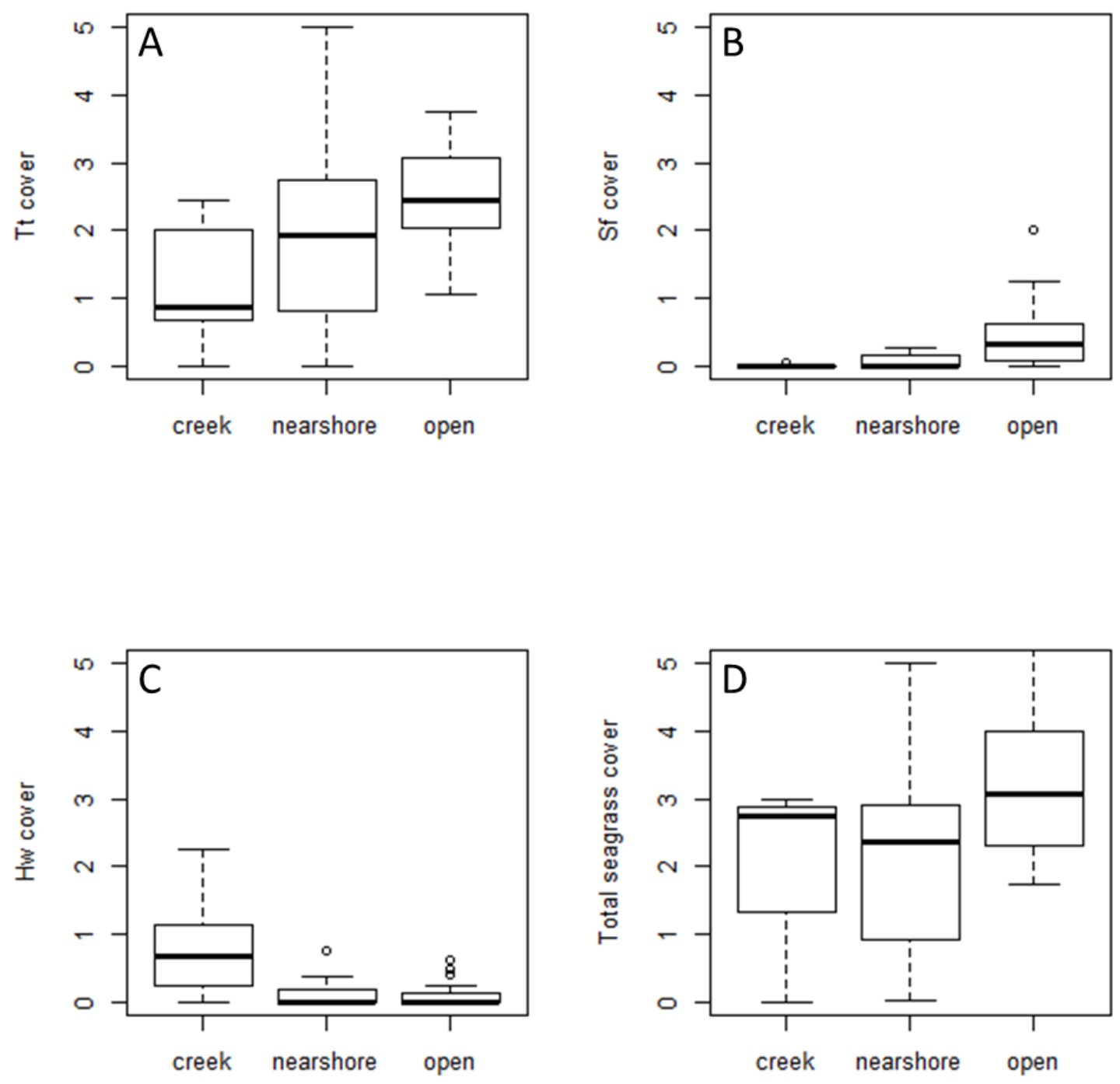

Figure 5. Box and whisker plots where the midline is the median, upper and lower limits of the box represent the $75^{\text {th }}$ and $25^{\text {th }}$ percentile, whiskers extend to minimum and maximum values except for data exceeding 1.5 times the interquartile range and are displayed as dots (possibly outliers). Spatial variation in mean Braun-Blanquet scores of seagrass for A) T. testudinum (Tt), B) S. filiforme (Sf), C) H. wrightii (Hw), and D) total seagrass cover (sum of scores of all seagrasses can exceed the max score of 5 because of the broad scoring categories (Fourqurean et al., 2001) 

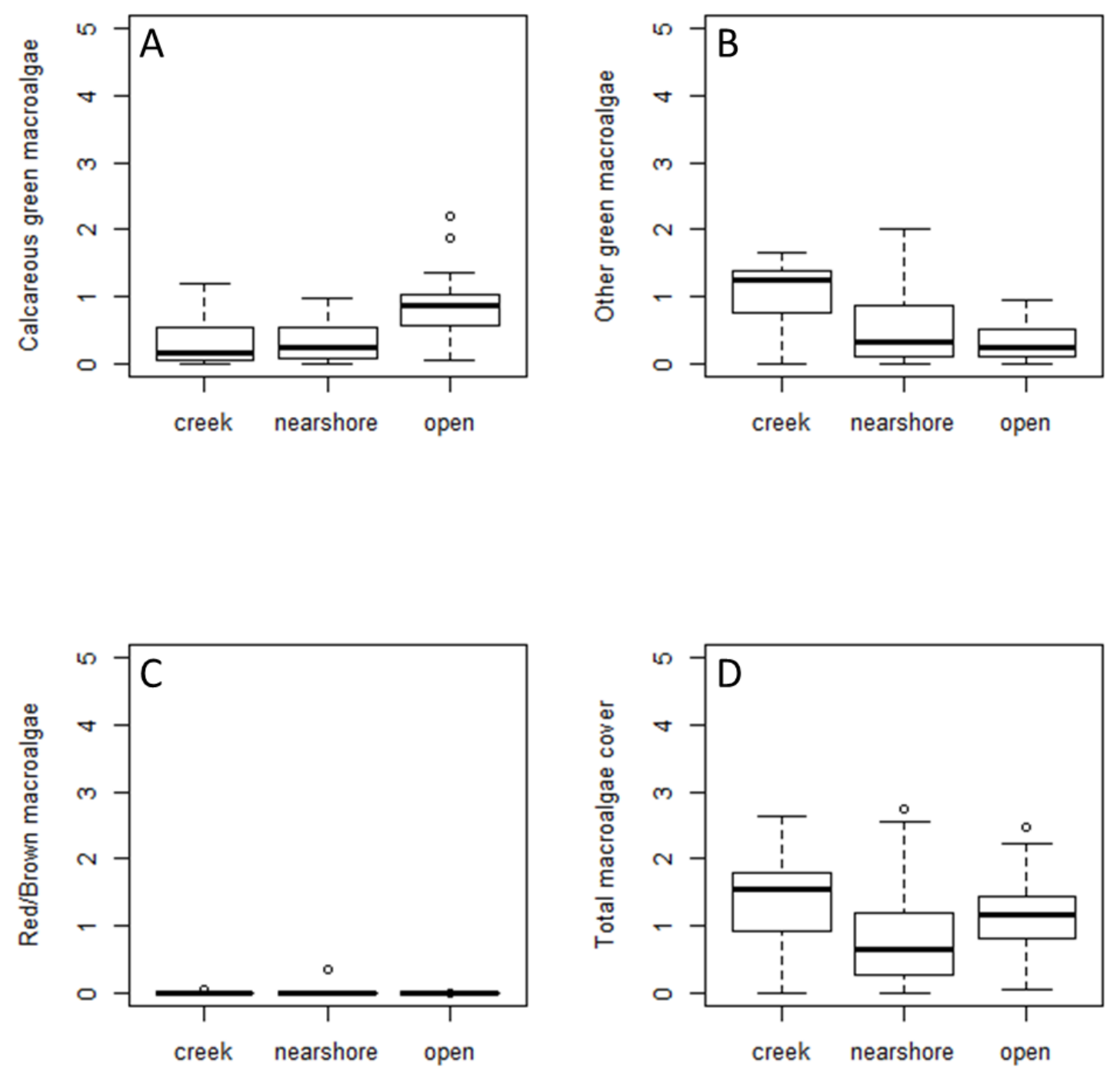

Figure 6. Mean Braun-Blanquet scores of macroalgae for A) calcareous green algae, B) other non-calcareous green algae, C) red and brown algae, and D) total macroalgae cover (sum of scores of all macroalgae can exceed the max score of 5 because of the broad scoring categories (Fourqurean et al., 2001) 


\section{Forage nutrient content}

T. testudinum leaf elemental values and ratios differed among habitats (Table 2, Figure 7). Nitrogen content was significantly greater in creek habitat than nearshore $(W=$ $145, P=0.0001)$ and open $(W=119, P<0.0001)$ and greater in nearshore than open $(W$ $=48, P<0.0001)$. Carbon content did not differ across habitats creek and nearshore $(W$ $=116, P=0.048)$, creek and open $(W=87, P=0.09)$, and open and nearshore $(W=$ $214, P=0.46)$. Phosphorus content was significantly greater in creek than nearshore ( $W$ $=129, P=0.006)$, but did not differ between open and creek $(W=88, P=0.075)$ or nearshore $(W=226, P=0.28)$. The $\mathrm{C}: \mathrm{N}$ ratios were significantly greater in open than nearshore $(W=338, P<0.0001)$ and creek $(W=0, P=0.0001)$ and greater in nearshore than creek $(W=9, P=<0.0001)$. The $\mathrm{C}: \mathrm{P}$ ratios were significantly greater in nearshore than creek $(W=31, P=0.02)$ but did not differ between open and creek $(W=33, P=$ $0.1)$ or nearshore $(W=146, P=0.25)$. The $\mathrm{N}: \mathrm{P}$ ratios were significantly greater in nearshore than open $(W=97, P=0.01)$ but did not differ between creek and nearshore $(W=80, P=0.90)$ or open $(W=86, P=0.1)$. The $\mathrm{C}: \mathrm{N}$ and $\mathrm{C}: \mathrm{P}$ ratios in the nearshore and open habitats were both greater than Redfield ratios, suggesting that those habitats are nutrient limited, and the low $\mathrm{N}: \mathrm{P}$ ratio suggests that the open habitat is limited by $\mathrm{N}$. Conversely, the high N:P ratios in the creek and nearshore habitats suggest that those habitats are likely $\mathrm{P}$ limited. 

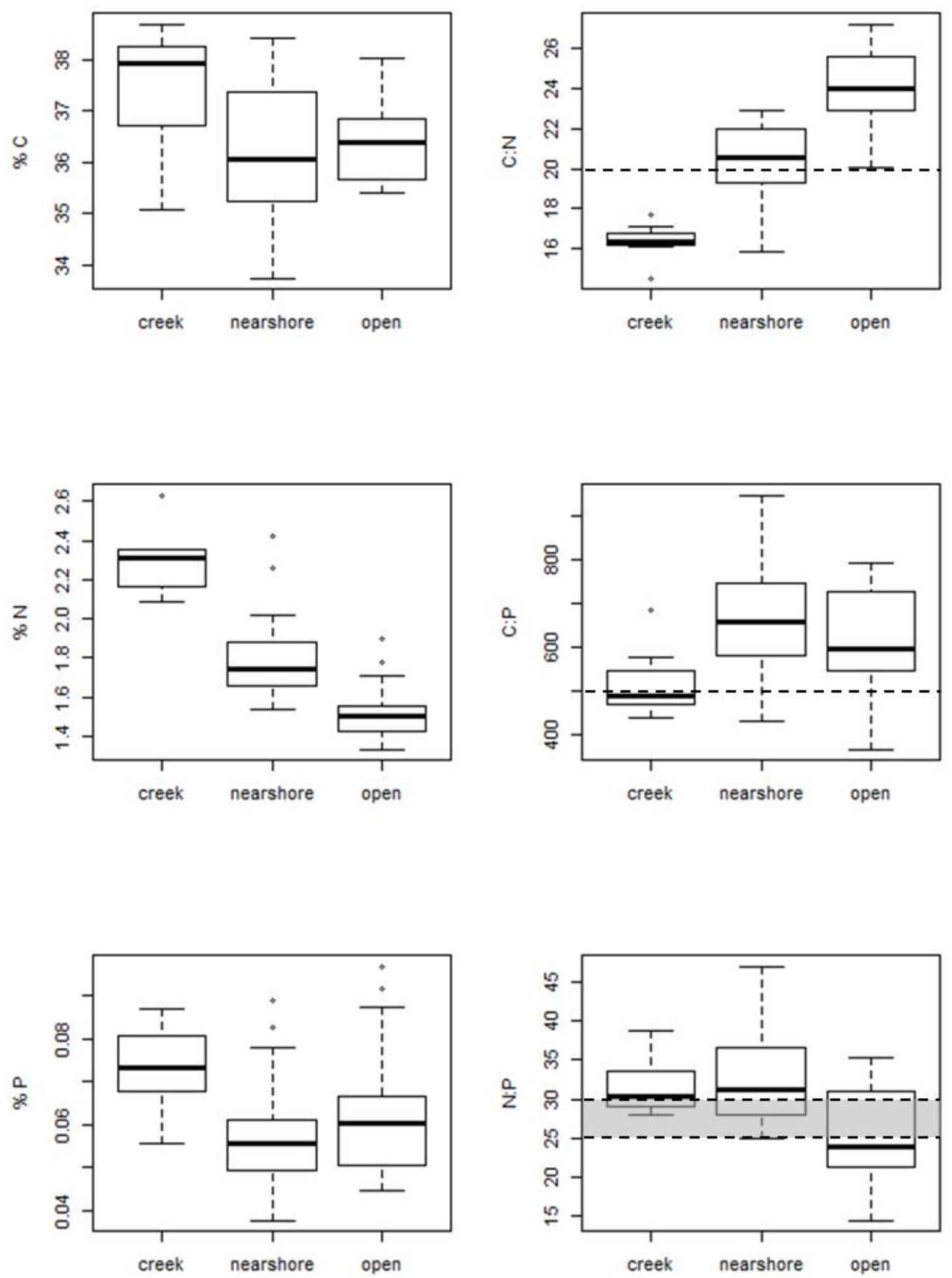

Figure 7. Spatial variation in nutrient content of seagrasses. Left (top-bottom): C, N, and $\mathrm{P}$ content T. testudinum per habitat; Right: Ratios of $\mathrm{C}: \mathrm{N}, \mathrm{C}: \mathrm{P}$, and $\mathrm{N}: \mathrm{P}$ for T. testudinum per habitat; the dashed lines represent the seagrass Redfield ratio. 


\section{Predator relative abundance}

Sharks were observed on 27 of 61 (44\%) BRUVs deployed in BOR. Six species including Carcharhinus acronotus (blacknose shark), Carcharhinus limbatus (blacktip shark), Carcharhinus perezi (Caribbean reef shark), Galeocerdo cuvier (tiger shark), Ginglymostoma cirratum (nurse shark), and Negaprion brevirostris (lemon shark) were observed. Tiger sharks, which regularly include sea turtles in their diets (e.g., Heithaus et al. 2008), were sighted on four of the 61 (6.6\%) BRUVs. Three of the four tiger sharks were captured on BRUVs in the open habitat and one in nearshore habitat, however, logistic regression revealed no significant difference in tiger shark observations between open and nearshore habitats $(Z=1.09, d f=43, P=0.28)$.

Sharks were observed on 8 of nine (89\%) BRUVs deployed in the creek habitat in 2018. However, only juvenile lemon sharks, that represent no risk to turtles, were observed.

\section{Turtle abundance and distributions}

Turtles were sighted 285 times on aerial video transects. Most sightings were of individual turtles, but up to 11 turtles were observed within a single video frame. The mean number of turtles per video frame during a sighting was $1.71 \pm 1.44(\mathrm{SD})$. Creeks had the highest total sightings (180) and mean sighting density (3.11 \pm 7.19 turtles/ha)

compared to nearshore (102 sightings; $1.14 \pm 5.77$ turtles/ha) and open ( 3 sightings; 0.03 \pm 0.18 turtles/ha) habitats (Figure 8). Wilcoxon rank sum tests revealed significant 
differences in sighting densities between open and nearshore habitats ( $\mathrm{W}=77.5, P<$ $0.0001)$ and open and creek habitats $(\mathrm{W}=234, P=0.0002)$, but sighting densities were not significantly different between creek and nearshore habitats $(\mathrm{W}=209, P=0.13$ ) (Figure 9). Mean sighting densities and high standard deviations occurred because turtles were concentrated in a few areas and absent in others (Figure 1).

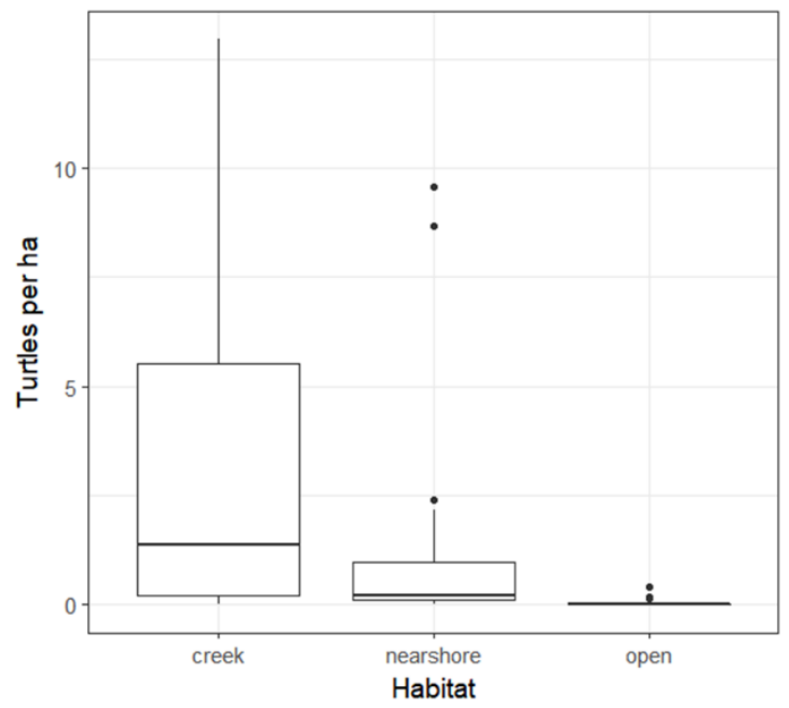

Figure 8. Turtle sighting density per habitat.

\section{Model selection}

Stepwise model selection of the generalized linear mixed effects model identified the best fit model to be:

$$
\text { Turtles } \sim \mathrm{Tt} * N+H w+(1 \mid \text { Habitat })+\operatorname{offset}(\log (\text { Area }))
$$

where Turtles is the sightings count, $T t$ and $H w$ represent the mean abundance of $T$. testudinum and $H$. wrightii, respectively, $N$ is the percent concentration of nitrogen in $T$. 
testudinum leaves, Habitat is set as the random effect and $\log ($ Area $)$ is effort as the model offset. The interaction T. testudinum and $\mathrm{N}$ is represented by $T t^{*} N$. Predictor variables and interactions considered in the model selection are listed in Table 3.

Table 3. Model selection table with models ranked by AIC score from best fitting model to worst, where $\mathrm{K}$ is the number of parameters in the model, AICc is the information criterion for each model, $\delta \mathrm{AICc}$ is the difference between the AIC of respective model and the best fitting model, ModelLik is the relative likelihood of the model given the data, AICcWt are the Akaike weights and indicate the level of support for the model being the most parsimonious, LL is the log-likelihood, and Cum.Wt is the cumulative model weight (Mazerolle, 2017).

\begin{tabular}{|c|c|c|c|c|c|c|c|}
\hline Model & $\mathrm{K}$ & $\mathrm{AICc}$ & $\delta \mathrm{AICc}$ & ModelLik & AlCcWt & LL & Cum.Wt \\
\hline $\mathrm{Tt}^{\star} \mathrm{N}+\mathrm{Hw}$ & 6 & 226.21 & 0.00 & 1.00 & 0.99 & -106.03 & 0.98784 \\
\hline $\mathrm{Tt}+\mathrm{Hw}+\mathrm{Sf}+\mathrm{Algae}+\mathrm{N}+\mathrm{C}+\mathrm{P}+\mathrm{Depth}+\mathrm{Tt}^{\star} \mathrm{N}$ & 11 & 235.01 & 8.80 & 0.01 & 0.01 & -102.50 & 0.99997 \\
\hline $\mathrm{Tt}^{\star} \mathrm{N}+\mathrm{P}$ & 6 & 249.04 & 22.83 & 0.00 & 0.00 & -117.44 & 0.99998 \\
\hline $\mathrm{Tt}^{\star} \mathrm{N}+\mathrm{P}+\mathrm{Depth}$ & 7 & 249.18 & 22.97 & 0.00 & 0.00 & -116.08 & 0.99999 \\
\hline $\mathrm{Tt}^{\star} \mathrm{N}$ & 5 & 251.31 & 25.10 & 0.00 & 0.00 & -119.90 & 1.00 \\
\hline$T t^{\star} \mathrm{N}+\mathrm{P}+$ Depth$+\mathrm{C}$ & 8 & 251.51 & 25.30 & 0.00 & 0.00 & -115.75 & 1.00 \\
\hline $\mathrm{Tt}+\mathrm{Hw}+\mathrm{Sf}+\mathrm{Algae}+\mathrm{N}+\mathrm{C}+\mathrm{P}+\mathrm{Depth}$ & 10 & 271.74 & 45.53 & 0.00 & 0.00 & -122.64 & 1.00 \\
\hline $\mathrm{Tt}+\mathrm{Hw}+\mathrm{Sf}+\mathrm{Algae}+\mathrm{N}+\mathrm{C}+\mathrm{P}$ & 9 & 275.22 & 49.01 & 0.00 & 0.00 & -126.11 & 1.00 \\
\hline $\mathrm{Tt}+\mathrm{Hw}+\mathrm{Sf}+\mathrm{Algae}+\mathrm{N}$ & 7 & 278.84 & 52.63 & 0.00 & 0.00 & -130.95 & 1.00 \\
\hline $\mathrm{Tt}+\mathrm{Hw}+\mathrm{Sf}+\mathrm{Algae}+\mathrm{N}+\mathrm{C}$ & 8 & 281.48 & 55.27 & 0.00 & 0.00 & -130.79 & 1.00 \\
\hline $\mathrm{P}$ & 3 & 340.72 & 114.51 & 0.00 & 0.00 & -167.07 & 1.00 \\
\hline Depth & 3 & 354.73 & 128.53 & 0.00 & 0.00 & -174.08 & 1.00 \\
\hline $\mathrm{N}$ & 3 & 359.93 & 133.73 & 0.00 & 0.00 & -176.68 & 1.00 \\
\hline C & 3 & 361.94 & 135.73 & 0.00 & 0.00 & -177.68 & 1.00 \\
\hline $\mathrm{Tt}+\mathrm{Hw}+\mathrm{Sf}+\mathrm{Algae}$ & 6 & 378.42 & 152.21 & 0.00 & 0.00 & -182.23 & 1.00 \\
\hline $\mathrm{Tt}+\mathrm{Hw}+\mathrm{Sf}$ & 5 & 380.09 & 153.89 & 0.00 & 0.00 & -184.37 & 1.00 \\
\hline $\mathrm{Tt}+\mathrm{Hw}$ & 4 & 382.33 & 156.12 & 0.00 & 0.00 & -186.72 & 1.00 \\
\hline $\mathrm{Tt}$ & 3 & 388.85 & 162.65 & 0.00 & 0.00 & -191.17 & 1.00 \\
\hline Sf & 3 & 406.53 & 180.33 & 0.00 & 0.00 & -200.01 & 1.00 \\
\hline $\mathrm{Hw}$ & 3 & 408.46 & 182.25 & 0.00 & 0.00 & -200.97 & 1.00 \\
\hline Algae & 3 & 410.50 & 184.29 & 0.00 & 0.00 & -201.99 & 1.00 \\
\hline
\end{tabular}

Accounting for differences among habitats by setting habitat as the random effect, turtle abundance is negatively correlated with $T$. testudinum and positively correlated 
with $H$. wrightii abundance (Table 4). The significant interaction between $T$. testudinum abundance and $\mathrm{N}$ content shows that, especially in the tidal creeks, although turtles were observed in areas with high T. testudinum abundance and low $\mathrm{N}$, the highest turtle densities were observed in areas with low T. testudinum abundance and high $\mathrm{N}$ (Figure 10).

Table 4. Results of generalized linear mixed effects best fit model; Significance codes: 0 '***', 0.001 '**, 0.01 '*', $0.05^{\prime}$ '’

Fixed effects:

\begin{tabular}{lrrrr}
\hline & Estimate Std. Error $z$ value & $\operatorname{Pr}(>|z|)$ \\
\hline (Intercept) & -3.14 & 1.19 & -2.64 & 0.01 \\
$\mathrm{Tt}$ & -3.71 & 0.54 & -6.94 & $0.00^{* * *}$ \\
$\mathrm{~N}$ & -0.62 & 0.56 & -1.11 & 0.27 \\
$\mathrm{Hw}$ & 0.94 & 0.19 & 5.01 & 0.00 \\
$\mathrm{Tt}: \mathrm{N}$ & 2.36 & 0.29 & 8.07 & 0.00 \\
\hline
\end{tabular}

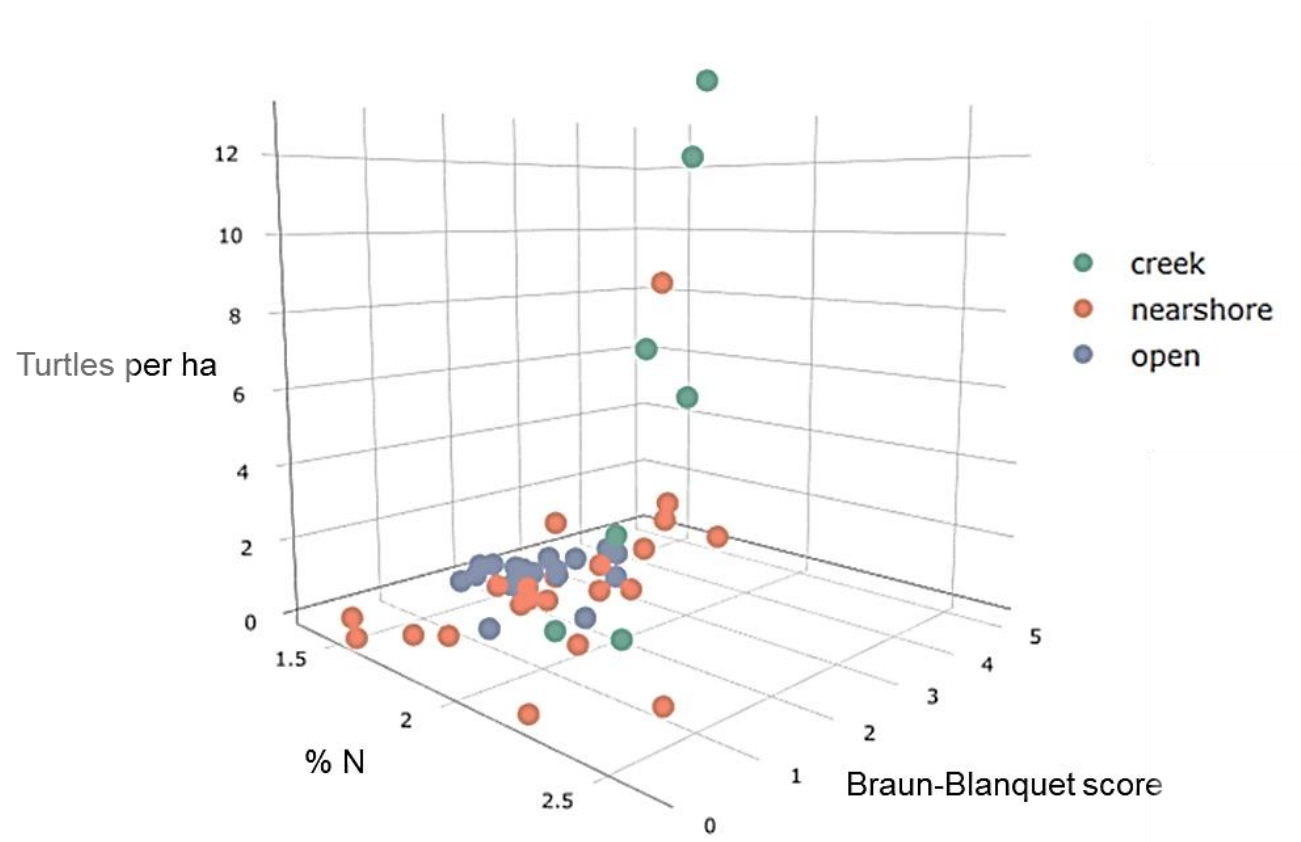

Figure 10. Turtle sightings per ha by $\% \mathrm{~N}$ content and Braun-Blanquet scores $T$. testudinum. 


\section{Discussion}

Herbivore habitat use decisions can be affected by both bottom-up and top-down forces. The basic Ideal Free Distribution (IFD; Fretwell and Lucas 1970) predicts that grazers should be distributed across habitats proportional to the availability of food. If this were the case, we would have expected higher turtle abundances in open habitats than in creek habitats. If turtles were avoiding predators, however, we predicted that turtles would largely avoid open and nearshore waters and instead select for creek habitat. Green turtle distributions were not consistent with an IFD using only seagrass cover. At broad spatial scales it appears that turtles are not using open foraging habitats despite these habitats having the greatest seagrass abundance. Indeed, only three turtles were observed in this habitat during the study suggesting that it is largely avoided.

While it is likely that avoiding predators plays some role in the space use decisions of turtles off Abaco at a broader spatial scale (i.e., avoiding open habitats almost entirely and low densities in most nearshore cells), food resources appear to shape turtle densities at small spatial scales and within particular habitats. Indeed, while the relationships between measures of food abundance and quality and turtle density were weak or even negative within open and nearshore habitats, within creek habitats, turtle densities were positively correlated with both $\mathrm{N}$ content of seagrasses and the presence of Haladule wrightii. The seagrass $H$. wrightii was most abundant in tidal creeks overall, but it was patchily distributed. In general, turtles were more abundant in areas with relatively high cover of $H$. wrightii, but their abundances were still high relative to nearshore and open habitats even in areas of creeks where $H$. wrightii was absent. Although it has been documented as a diet component of green turtles (see review by Forbes, 1996), it has not 
been documented as a major component of their diets. Relative to other seagrass species, H. wrightii in other parts of the Caribbean has high $\mathrm{N}$ content (Chapter IV). If turtles off Abaco are using $H$. wrightii as a $\mathrm{N}$ rich food source, carrying capacity $(\mathrm{K})$ in areas like the tidal creeks could be higher than estimates based solely on T. testudinum.

Herbivores often forage selectively to meet nutritional requirements (Simpson et al., 2004). The non-gregarious, non-territorial, high-arctic Avalbard reindeer (Rangifer tarandus platyrhinchus) in habitats with low forage availability and productivity selected home ranges and resource patches on the basis of productivity, however, reindeer in habitats with high forage availability and productivity selected habitats based on conditions supportive of high forage quality over forage biomass (Hansen et al., 2009). Dugong (Dugong dugong) habitat selection is context dependent in that they will selected seagrass patches for high nitrogen concentrations during high tides, however, when habitat space was limited by low tides, their habitat use shifted to patches with high seagrass biomass (Sheppard et al., 2010). Green turtles in other parts of the Caribbean select forage according to nutrient content (N, P, and soluble sugars) relative to other available forage options (Bjorndal, 1997; Christianen et al., 2018).

Although turtles off Abaco face a food abundance-safety tradeoff, they do not appear to need to trade off food quality for safety. Indeed, turtle densities in creeks showed a positive correlation with $\mathrm{N}$ content, and all samples of T. testudinum from creeks had higher $\mathrm{N}$ content than all samples from open habitats and most from nearshore habitats. Therefore, it is possible that turtles may be able to obtain adequate energy and nutrient intake rates in creek habitats that are safe and support continued growth of 
seagrasses that have high nutrient content. The ability of the tidal creeks to support the current local turtle population, however, would require that turtles on the Abaco foraging ground are not bottom-up limited and not near the carrying capacity of the Bight of Old Robinson overall. Indeed, if the resident turtle population was near carrying capacity, we would expect lower-condition turtles to begin using suboptimal habitats or those that feature higher predation risk (e.g., Heithaus et al. 2007).

Off Great Abaco, turtles may benefit from the geological setting of their foraging habitats. Indeed, seagrasses within what would normally be oligotrophic tidal creeks appear to be benefiting from allochthonous nutrient inputs from nearby blue holes (Lapointe et al., 2004), which could combine with the enhanced nutrient cycling facilitated by the turtles themselves (Thayer, Engel and A. Bjorndal, 1982; Bjorndal, 1997; Kelkar et al., 2013) to allow seagrasses to maintain high nutrient content in the face of heavy herbivory. Because other tidal creeks without blue holes support grazing turtle populations off Abaco (pers. obs.), further studies of the links between nutrient inputs and turtle contributions to turtle nutrient recycling are needed to test the hypothesis that nutrient outputs from blue holes provide adequate nutrients to support seagrasses under concentrated grazing pressure. Such studies should help in identifying likely highquality habitats for turtles that should be targeted for conservation in the face of increasing human pressures on coastal systems.

Green turtles in Abaco appear to conform to the Foraging Arena hypothesis with the population divided into vulnerable and invulnerable population components (Ahrens, Walters and Christensen, 2012; Colléter et al., 2015). The vulnerable population 
component in open and nearshore waters is at generally very low density and densities do not correlate with measures of food abundance or quality. In contrast, a relatively high density invulnerable population occurs in the foraging arena of tidal creeks. At the current population density, green turtles may be able to maintain the vulnerable component at low densities because of the relatively high nitrogen content in the creek habitat seagrass. This contrasts with studies in Shark Bay, Australia where, although both turtles (Heithaus, Frid and Dill, 2002; Heithaus et al., 2007) and dugongs (Wirsing, Heithaus and Dill, 2007) trade-off food for safety, they are constrained because the vast majority of foraging options are in dangerous areas. Unlike in Abaco, the Shark Bay herbivores are limited in their ability to reduce the vulnerable population component because of the limited forage in less dangerous areas. Also, there are no habitats in Shark Bay where these herbivores can forage free from risk. Even "safe" habitats are risky to some degree, whereas in Abaco turtles have a true refuge from large predators where they can forage. Because trophic interactions are restricted to the vulnerable prey foraging arenas, if population and individual growth rates increase the invulnerable population component could exceed carrying capacity of the tidal creeks in Abaco and push individuals into vulnerable habitats, increasing the turtle densities in nearshore and open water habitats.

Tidal creeks may be particularly critical habitats for rebuilding sea turtle populations. The high variance in nearshore waters because of turtle concentrations in several cells found very close to shore in the SE portion of the study area, suggests that identifying critical habitat for herbivores requires analysis of their habitat use at multiple scales (i.e., landscape and patch). Continued monitoring of green turtle distributions and 
partitioning of the population should be considered in future management and protection plans. The protected shark populations in Abaco may be preventing unchecked grazing by green turtles, and the exchange of individuals from the invulnerable (creek) to the vulnerable (open water) population components could signal that the preferred habitat has reached carrying capacity, thus requiring updates to any current conservation and management plans.

Previous estimates of green turtle carrying capacity $(\mathrm{K})$ in the Caribbean used seagrass (T. testudinum) cover and productivity as a proxy for food availability (Bjorndal and Jackson 2002; Jackson 2001), however, Heithaus et al. (2008) argued that the available foraging habitat for green turtles is restricted by risk of predation. Green turtle distributions in Abaco support the argument that $\mathrm{K}$ estimates derived from seagrass cover are likely overestimates. Updated regional estimates of $\mathrm{K}$ would benefit from the consideration of other factors that may constrain foraging habitat use such as predation (this Chapter, Heithaus et al. 2008), human impacts (Frid and Dill, 2002), and invasive species (Chapters IV and V).

\section{Acknowledgments}

This work was funded by Paul G. Allen Philanthropies as part of the Global FinPrint Project. Additional in-kind support was provided by PADI Foundation, the Judith Evans Parker Travel Scholarship, FIU Biology Department travel grants, and a Florida International University Graduate School Data Evidence Acquisition Fellowship. Friends of the Environment, Joy Chaplin, and Pete's Pub provided on-site logistical 
support. Thanks to Michael Heithaus for guidance at every stage of the project. The bulk of the field assistance was provided by Ryley Parent, Valeria Paz, and The Science Exchange intern Justine Thompson. Research was conducted under IACUC permits \#200508 and \#200548. Additional permits were provided by The Bahamas Ministry of Agriculture and Marine Resources and overseen by Bahamas National Trust.

\section{References}

Ahrens, R. N. M., Walters, C. J. and Christensen, V. (2012). Foraging arena theory, Fish and Fisheries, 13(1), pp. 41-59. doi: 10.1111/j.1467-2979.2011.00432.x.

Allgeier, J. E. (2010). Synergistic nutrient colimitation across a gradient of ecosystem fragmentation in subtropical mangrove-dominated wetlands, Limnology and Oceanography, 55(6), pp. 2660-2668. doi: 10.4319/lo.2010.55.6.2660.

Allgeier, J. E., Rosemond, A. D. and Layman, C. A. (2011). Variation in nutrient limitation and seagrass nutrient content in Bahamian tidal creek ecosystems, Journal of Experimental Marine Biology and Ecology. Elsevier B.V., 407(2), pp. 330-336. doi: 10.1016/j.jembe.2011.07.005.

Bjorndal, K. A. (1982). The consequences of herbivory for the life history pattern of the Caribbean green turtles, Chelonia mydas, Biology and Conservation of Sea Turtles. Washington, D.C.: Smithsonian Institution Press, pp. 111-116.

Bjorndal, K. A. (1985). Nutritional Ecology of Sea Turtles, Copeia, (3), pp. 736-751.

Bjorndal, K. A. (1997). Foraging ecology and nutrition of sea turtles, P.L. Lutz, J.A. Musick (Eds.), The Biology of Sea Turtles, CRC Press (1997), pp. 199-231

Bond, M. E. et al. (2012). Reef sharks exhibit site-fidelity and higher relative abundance in marine reserves on the Mesoamerican Barrier reef, PLoS ONE, 7(3), pp. 1-14. doi: 10.1371/journal.pone.0032983.

Brand-Gardner, S., Lanyon, J. and Limpus, C. J. (1999). Diet selection by immature green turtles, Chelonia mydas, in subtropical Moreton Bay, south-east Queensland, Australian Journal of Zoology, 47(2), pp. 181-191. 
Braun-Blanquet, J. (1932). Plant sociology. The study of plant communities. Plant sociology. The study of plant communities. First ed.

Braun-Blanquet, J. (1964) Pflanzensoziologie: grundzüge der vegetationskunde.

Burkholder, D. A. et al. (2013). Patterns of top-down control in a seagrass ecosystem: could a roving apex predator induce a behaviour-mediated trophic cascade?, The Journal of Animal Ecology, 82(6), pp. 1192-1202. doi: 10.1111/13652656.12097.

Christianen, M. J. A. et al. (2014). Habitat collapse due to overgrazing threatens turtle conservation in marine protected areas, Proceedings of the Royal Society B: Biological Sciences, 281(20132890), p. 7.

Christianen, M. J. A. et al. (2018). Megaherbivores may impact expansion of invasive seagrass in the Caribbean, Journal of Ecology, pp. 0-1. doi: 10.1111/13652745.13021.

Clutton-Brock, T. H., Iason, G. R. and Guinness, F. E. (1987). Sexual segregation and density-related changes in habitat use in male and female Red deer (Cervus elaphus), Journal of Zoology London, (211), pp. 275-289.

Colléter, M. et al. (2015). Including foraging arena and top-down controls improves the modeling of trophic flows and fishing impacts in aquatic food webs, Marine Ecology Progress Series, 534, pp. 17-37. doi: 10.3354/meps11357.

Creel, S. et al. (2005). Elk Alter Habitat Selection as an Antipredator Response to Wolves, Ecology, 86(12), pp. 3387-3397.

DJI (2017) Phantom 3 Advanced User Manual (EN) v1.8. Shenzhen, China: Author.

Duarte, C. M. (1990). Seagrass nutrient content, Marine Ecology Progress Series, 67(April), pp. 201-207-207. doi: 10.3354/meps067201.

Estes, J. A. et al. (2011). Trophic downgrading of planet earth. Science 333 (6040), 301306, Science, 333(6040), pp. 301-307.

Estes, J. A. et al. (2016). Megafaunal Impacts on Structure and Function of Ocean Ecosystems, Annual Review of Environment and Resources. doi: 10.1146/annurev-environ-110615-085622.

Ferretti, F. et al. (2010). Patterns and ecosystem consequences of shark declines in the ocean, Ecology letters, 13(8), pp. 1055-71. doi: 10.1111/j.1461-0248.2010.01489. 
Forbes, G. A. (1996). The diet and feeding ecology of the green sea turtle (Chelonia mydas) in an algal-based coral reef community. James Cook University. Available at: http://eprints.jcu.edu.au/27399/ (Accessed: 11 October 2013).

Fourqurean, J. W. et al. (2001). Spatial and temporal pattern in seagrass community composition and productivity in south Florida, Marine Biology, 138(2), pp. 341354. doi: 10.1007/s002270000448.

Fourqurean, J. W. et al. (2010). Effects of excluding sea turtle herbivores from a seagrass bed: Overgrazing may have led to loss of seagrass meadows in Bermuda, Marine Ecology Progress Series, 419, pp. 223-232. doi: 10.3354/meps08853.

Gary, M. (2017). Home Range and Habitat Use of Juvenile Green Turtles in a Shallow Tidal Environment. Florida Atlantic University.

Gilbert, E. (2005). Juvenile green turtle (Chelonia mydas) foraging ecology: feedingselectivity and forage nutrient analysis. University of Central Florida Electronic.

Hadjichristophoroua, M. and Grove, D. J. (1983). A study of appetite, digestion and growth in juvenile green turtle (Chelonia mydas L.) fed on artificial diets, Aquaculture, 30(1-4), pp. 191-201.

Hansen, B. B. et al. (2009). Functional response in habitat selection and the tradeoffs between foraging niche components in a large herbivore, Oikos, 118(6), pp. 859872. doi: 10.1111/j.1600-0706.2009.17098.x.

Hays, G. C. et al. (2002). Behavioural plasticity in a large marine herbivore: contrasting patterns of depth utilisation between two green turtle (Chelonia mydas) populations, Marine Biology, 141, pp. 985-990. doi: 10.1007/s00227-002-0885-7.

Heithaus, M. R. et al. (2007). State-dependent risk-taking by green sea turtles mediates top-down effects of tiger shark intimidation in a marine ecosystem, The Journal of animal ecology, 76(5), pp. 837-44. doi: 10.1111/j.1365-2656.2007.01260.x.

Heithaus, M. R. et al. (2008). Predicting ecological consequences of marine top predator declines, Trends in Ecology and Evolution, 23(4), pp. 202-210. https://doi.org/10.1016/j.tree.2008.01.003

Heithaus, M. R. et al. (2008). A review of lethal and non-lethal effects of predators on adult marine turtles, Journal of Experimental Marine Biology and Ecology, 356(1-2), pp. 43-51. doi: 10.1016/j.jembe.2007.12.013.

Heithaus, M. R. (2013). Predators, Prey, and the Ecological Roles of Sea Turtles, in The Biology of Sea Turtles, Volume III, pp. 249-285. 
Heithaus, M. R. et al. (2014). Seagrasses in the age of sea turtle conservation and shark overfishing, Frontiers in Marine Science, 1(August), pp. 1-6. doi: 10.3389/fmars.2014.00028.

Heithaus, M. R., Frid, A. and Dill, L. M. (2002). Shark-inflicted injury frequencies, escape ability, and habitat use of green and loggerhead turtles, Marine Biology, 140(2), pp. 229-236. doi: 10.1007/s00227-001-0712-6.

Heithaus, M. R., Wirsing, A. J. and Dill, L. M. (2012). The ecological importance of intact top-predator populations: a synthesis of 15 years of research in a seagrass ecosystem, Marine and Freshwater Research, 63(11), p. 1039. doi: 10.1071/MF12024.

Jackson, J. B. C. (2001). What was natural in the coastal oceans?, Proceedings of the National Academy of Sciences of the United States of America, 98(10), pp. 54118. doi: 10.1073/pnas.091092898.

Kelkar, N. et al. (2013). Greener pastures? High-density feeding aggregations of green turtles precipitate species shifts in seagrass meadows. Journal of Ecology, 101(5), 1158-1168. https://doi.org/10.1111/1365-2745.12122

Kiszka, J. J. et al. (2016). Using unmanned aerial vehicles (UAVs) to investigate shark and ray densities in a shallow coral lagoon, Marine Ecology Progress Series, 560, pp. 237-242. doi: 10.3354/meps11945.

Kuznetsova, A., Brockhoff, P. B. and Christensen, R. H. B. (2018). Tests in Linear Mixed Effects Models. Available at: https://github.com/runehaubo/lmerTestR\%0ABugReports.

Lapointe, B. E. et al. (2004). The relative importance of nutrient enrichment and herbivory on macroalgal communities near Norman's Pond Cay, Exumas Cays, Bahamas: a "natural" enrichment experiment, Journal of Experimental Marine Biology and Ecology, 298(2), pp. 275-301. doi: 10.1016/S0022-0981(03)003630 .

Lowry, M. et al. (2012). Comparison of baited remote underwater video (BRUV) and underwater visual census (UVC) for assessment of artificial reefs in estuaries, Journal of Experimental Marine Biology and Ecology. Elsevier B.V., 416-417, pp. 243-253. doi: 10.1016/j.jembe.2012.01.013.

Massé, A. and Côté, S. D. (2009). Habitat Selection of a Large Herbivore at High Density and Without Predation: Trade-off between Forage and Cover?, Journal of Mammalogy, 90(4), pp. 961-970. doi: 10.1644/08-MAMM-A-148.1. 
Mazerolle, M. J. (2017). AICcmodavg: Model selection and multimodel inference based on (Q)AIC(c). R package version 2.1-1. https://cran.r-

project.org/package=AICcmodavg.

Mobæk, R. et al. (2009). Density dependent and temporal variability in habitat selection by a large herbivore ; an experimental approach, (September 2008). doi:

10.1111/j.1600-0706.2008.16935.x.

Mysterud, A. (2006). The concept of overgrazing and its role in management of large herbivores, Wildlife Biology, 2(2), pp. 129-141.

Power, M. (1992). Top-down and bottom-up forces in food webs: do plants have primacy, Ecology, 73(3), pp. 733-746. Available at:

http://www.esajournals.org/doi/abs/10.2307/1940153

Preen, A. R. (1993). Interactions between dugongs and seagrass in a subtropical environment. Ph. D. Dissertation. James Cook University.

QGIS Development Team (2018). QGIS Geographic Information System. Open Source Geospatial Foundation Project. http://qgis.osgeo.org

R Core Team (2016). R: A language and environment for statistical computing. R Foundation for Statistical Computing, Vienna, Austria. URL https://www.Rproject.org/.

Ramp, D. et al. (2002). Density dependence in foraging habitat preference of eastern grey kangaroos, Oikos, 98(March), pp. 393-402.

Raynor, E. J., Joern, A. and Briggs, J. M. (2015). Bison foraging responds to fire frequency in nutritionally heterogeneous grassland, Ecology, 96(6), pp. 15861597. doi: 10.1890/14-2027.1.

Rees, A. et al. (2017). The potential of unmanned aerial systems for sea turtle research and conservation: a review and future directions', Endangered Species Research, 35, pp. 81-100. doi: 10.3354/esr00877.

Sandhu, P. et al. (2018). Worms Make Risky Choices Too: The effect of starvation on foraging in the common earthworm, Lumbricus terrestris, Canadian Journal of Zoology, pp. 1-28.

Seagle, S. W. and Mcnaughton, S. J. (1992). Serengeti grazing ungulates, Landscape Ecology, 7(4), pp. 229-241. 
Sheppard, J. K. et al. (2010). Dugong habitat use in relation to seagrass nutrients, tides, and diel cycles, Marine Mammal Science, 26(4), pp. 855-879. doi:

10.1111/j.1748-7692.2010.00374.x.

Simpson, S. J. et al. (2004). Optimal foraging when regulating intake of multiple nutrients, Animal Behaviour, 68(6), pp. 1299-1311. doi:

10.1016/j.anbehav.2004.03.003.

Sinclair, A. R. E. and Arcese, P. (1995). Population Consequences of Predation-Sensitive Foraging: The Serengeti Wildebeest, Ecology, 76(3), pp. 882-891.

Solórzano, L. and Sharp, J. H. (1980). Determination of total dissolved phosphorus and particulate phosphorus in natural waters, Limnology and Oceanography, 25(4), pp. 754-758.

Stoner, E. W. et al. (2011). Effects of anthropogenic disturbance on the abundance and size of epibenthic jellyfish Cassiopea spp., Marine Pollution Bulletin. Elsevier Ltd, 62(5), pp. 1109-14. doi: 10.1016/j.marpolbul.2011.03.023.

Stoner, E. W. et al. (2014). Modification of a seagrass community by benthic jellyfish blooms and nutrient enrichment, Journal of Experimental Marine Biology and Ecology, 461, pp. 185-192. doi: 10.1016/j.jembe.2014.08.005.

Thayer, G. W., Engel, D. W. and A. Bjorndal, K. (1982). Evidence for short-circuiting of the detritus cycle of seagrass beds by the green turtle, Chelonia mydas L., Journal of Experimental Marine Biology and Ecology, 62(2), pp. 173-183. doi: 10.1016/0022-0981(82)90090-9.

Van der Wal, R. et al. (2000). Trading forage quality for quantity? Plant phenology and patch choice by Svalbard reindeer, Oecologia, 123, pp. 108-115.

Ward-Paige, C. a et al. (2010). Large-scale absence of sharks on reefs in the greaterCaribbean: a footprint of human pressures, PloS one, 5(8), p. e11968. doi: 10.1371/journal.pone.0011968.

Weber, S. B. et al. (2014). Recovery of the South Atlantic's largest green turtle nesting population, Biodiversity and Conservation, 23(12), pp. 3005-3018. doi: 10.1007/s10531-014-0759-6.

Wirsing, A. J., Heithaus, M. R. and Dill, L. M. (2007). Fear factor: Do dugongs (Dugong dugon) trade food for safety from tiger sharks (Galeocerdo cuvier)?, Oecologia, 153(4), pp. 1031-1040. doi: 10.1007/s00442-007-0802-3. 
Yeager, L. A., Acevedo, C. L. and Layman, C. A. (2012). Effects of seascape context on condition, abundance, and secondary production of a coral reef fish, Haemulon plumierii, Marine Ecology Progress Series, 462, pp. 231-240. doi: 10.3354/meps09855. 


\section{Appendix I.}

Parametric and non-parametric mixed effects model selection methods yielded comparable results. Linear mixed effects models with Satterthwaite's degrees of freedom in the lmerTest package were used to test for relationships between turtle sighting density, with an assumed Gaussian distribution, and habitat variables with habitat type set as the random intercept for all complete cells (i.e., no missing data). Backward reduced fixed-effect model selection was employed to identify factors that affected turtle sighting densities (Table A. Kuznetsova, Brockhoff and Christensen, 2018). The parametric methods yielded the best fit model:

$$
\text { Turtles_per_ha Tt }+H w+N+(1 \mid \text { Habitat })
$$

where Turtles_per_ha is the sighting density of turtles, $T t$ and $H w$ represent the mean abundance of $T$. testudinum and $H$. wrightii, respectively, $N$ is the percent concentration of nitrogen in T. testudinum leaves, and Habitat is set as the random effect. Predictor variables and interactions considered in the backward reduced fixed-effect model selection are listed in Table A. This best fit model differs from the non-parametric model only in that it does not include the interaction between $T t$ and $N$. 
Table A. Backward reduced fixed-effect table with Satterthwaite's degrees of freedom method used to compute the denominator degrees of freedom (DenDF); The simply additive model yielded the same results, but interactions are included in the table for comparison; Significance codes: 0

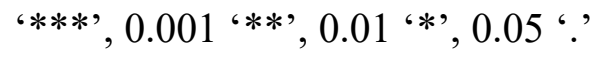

Backward reduced fixed-effect table:

\begin{tabular}{lccccccc}
\hline & Eliminated & Df & Sum of Sq & RSS & AIC & F value & $\operatorname{Pr}(>\mathrm{F})$ \\
\hline Tt:P & 1 & 1 & 0.001 & 170.72 & 84.001 & 0.0001 & 0.991155 \\
Sf & 2 & 1 & 0.104 & 170.82 & 82.028 & 0.0201 & 0.888134 \\
Tt:C & 3 & 1 & 0.178 & 171 & 80.075 & 0.0353 & 0.852009 \\
$\mathrm{C}$ & 4 & 1 & 0.467 & 171.47 & 78.198 & 0.0957 & 0.758921 \\
$\mathrm{P}$ & 5 & 1 & 0.485 & 171.95 & 76.325 & 0.1018 & 0.751554 \\
Depth & 6 & 1 & 0.524 & 172.48 & 74.462 & 0.1127 & 0.739022 \\
Tt:Algae & 7 & 1 & 2.39 & 174.87 & 73.081 & 0.5265 & 0.472545 \\
Algae & 8 & 1 & 9.688 & 184.55 & 73.508 & 2.1608 & 0.149597 \\
Tt:N & 9 & 1 & 17.013 & 201.57 & 75.476 & 3.6874 & 0.061976 \\
$\mathrm{Tt}$ & 0 & 1 & 27.795 & 229.36 & 79.289 & 5.6536 & 0.022164 \\
$\mathrm{Hw}$ & 0 & 1 & 48.103 & 249.67 & 83.107 & 9.7845 & 0.003234 \\
$\mathrm{~N}$ & 0 & 1 & 59.996 & 261.56 & 85.201 & 12.2035 & 0.001158
\end{tabular} **

The best fit linear mixed effects model suggests that turtle sighting density is positively correlated with $\mathrm{Tt}$ and $\mathrm{Hw}$ (Table B). This differs from the generalized mixed effects model in the direction of correlation with Tt. Because the sighting data were heavily skewed with a high number of zeros and small values, the non-parametric generalized linear mixed effects model was selected over this parametric model.

Table B. Results from the best fit linear mixed effects model; Significance codes: 0 '***', 0.001 '**', $0.01^{\text {'*', }}, 0.05^{\prime}$ '.

Fixed effects:

\begin{tabular}{|c|c|c|c|c|c|}
\hline & Estimate & Std. Error & df & $t$ value & $\operatorname{Pr}(>|t|)$ \\
\hline (Intercept) & -6.2075 & 3.3453 & 14.7062 & -1.856 & 0.0837 \\
\hline $\mathrm{Tt}$ & 0.7724 & 0.3334 & 38.0402 & 2.317 & 0.026 \\
\hline $\mathrm{Hw}$ & 2.2873 & 0.9532 & 40.9977 & 2.4 & 0.021 \\
\hline $\mathrm{N}$ & 3.2757 & 1.6612 & 25.9234 & 1.972 & 0.0594 \\
\hline
\end{tabular}


CHAPTER IV

LARGE-BODIED FORAGING HABITAT USE AND RESOURCE SELECTION IS AFFECTED BY THE INVASIVE SEAGRASS, HALOPHILA STIPULACEA, IN THE FRENCH WEST INDIES 


\begin{abstract}
Invasive plant species can alter grazer foraging habitat use and resource selection and ultimately affect survival and fitness - if the invasive species is of lower quality than native species or herbivores fail to recognize it as potential food. Across three islands of the French West Indies (Guadeloupe, Martinique, and Saint Martin), I explored how Caribbean green turtles (Chelonia mydas) selected microhabitats, and resources within those microhabitats, at foraging areas that featured mixes of native Syringodium filiform, T. testudinum, and Halodule wrightii, and the invasive seagrass Halophila stipulacea.
\end{abstract} From 2016-2017, I used belt transects to assess spatial variation in turtle densities and resource selection relative to macrophyte abundance, species composition, and nutrient content $(\mathrm{C}, \mathrm{N}, \mathrm{P})$. Each study site presented unique relationships of nutrients among seagrasses. There was little detectable difference between native S. filiforme and invasive $H$. stipulacea in nutrient content off Guadeloupe, however, off Martinique, native $T$. testudinum contained greater $\mathrm{N}$ but less $\mathrm{P}$ than $H$. stipulacea, and S. filiforme was lower in both nutrients than the invasive. Off St. Martin invasive seagrass was not abundant and T. testudinum had the highest nutrient content of native species. At all sites turtles selected areas with abundant native seagrasses (T. testudinum, S. filiforme) and avoided areas typified by macroalgae and the invasive seagrass. Together, these data suggest that the spread of invasive seagrasses is currently resulting in a decrease in the habitat area that turtles perceive as quality foraging habitat, and interspecific variation in nutrient content alone may not be responsible for this pattern. If turtles are energy or nutrientlimited, restricted use of space and resources should have negative consequences on individual- and population-level energy budgets. In addition, turtle avoidance of the 
invader likely is facilitating its spread. The ability of green turtle populations to adapt to decreases in habitat because of the invasion of a non-native seagrass or to expand their diets to take advantage of novel food resources, however, remains unclear and is an important aspect of turtle foraging ecology for further investigation in the face of macrophyte invasions.

\section{Introduction}

Invasive plants have modified both terrestrial and aquatic ecosystems and affect both biotic and abiotic components of ecosystems. Invasive terrestrial grasses (Bromus tectorum and Bromus rubens) have altered fire regimes in western North America (Brooks and Esque, 2002; Brooks et al., 2004), negatively affecting critical habitat for many native fauna including the endangered desert tortoise (Gopherus agassizii). In the Mediterranean, 19 species of invasive algae were reportedly among the "100 Worst Invasives" in the Mediterranean in 2006 (Streftaris and Zenetos, 2006), causing changes in chemical and physical processes and decreasing macrophyte biodiversity.

Understanding habitat use decisions of herbivores is important in the face of plant species invasions because space-use patterns influence the spatiotemporal pattern of access to resources and top-down impacts on ecosystems. Furthermore, habitat use patterns of herbivores likely are already changing in response to other ecosystem changes including population declines of apex predators and eutrophication and other disruptions to basal resources. Prey species, like the vast majority of herbivores, often have to make foraging decisions on the basis of food-risk tradeoffs (e.g., Power 1983; Verdolin 2006; 
Heithaus et al. 2007), with the strength of behavioral response likely varying with the degree of energy stress (e.g., Clark 1994, Lima and Bednekoff 1999, Heithaus et al. 2008). In the absence of predation pressure, however, grazers are free to make their foraging and habitat use decisions using other factors.

The invasion of the seagrass Halophila stipulacea is changing the composition of many seagrass communities in the eastern Caribbean, and there is concern about potential loss of some ecosystem functions of seagrass meadows because of structural differences between the invasive and native seagrasses (Figure 1; Willette and Ambrose 2009). The seagrass, $H$. stipulacea, is native to the Indian Ocean, has successfully spread to the Mediterranean and Caribbean and is one of only two known invasive seagrass species to have transoceanic establishment (Ruiz and Ballantine, 2004). Although it is unknown how $H$. stipulacea will affect ecosystem function, invasive species have the ability to facilitate native species through direct and indirect interactions (Rodriguez, 2006). An invasive reed grass (Spartina alterniflora) is hybridizing with a native reed grass (Spartina foliosa) in San Francisco Bay creating a more structurally defended grass that is avoided by grazing western Canada geese (Branta canadensis moffitti) (Grosholz, 2010). The only documented trans-oceanic seagrass invader prior to $H$. stipulaceae was Zostera japonica which positively affected some native species of benthic invertebrates by providing enhanced refuge because of structural changes in seagrass communities (Posey, 1988). A review of the impacts of alien marine species in Europe found that of 63 species studied, most were reported to have both positive and negative effects on ecosystem services and biodiversity, however, the authors suggest that there is often a preconceived bias against alien species and positive effects may be understudied and 
underreported (Katsanevakis et al. 2014). Here, I investigate the effects of an invasive seagrass, H. stipulacea, on space use of green sea turtles (Chelonia mydas) at multiple sites and across multiple sampling events and consider the potential reciprocal effects of turtles on the success of $H$. stipulacea's invasion.

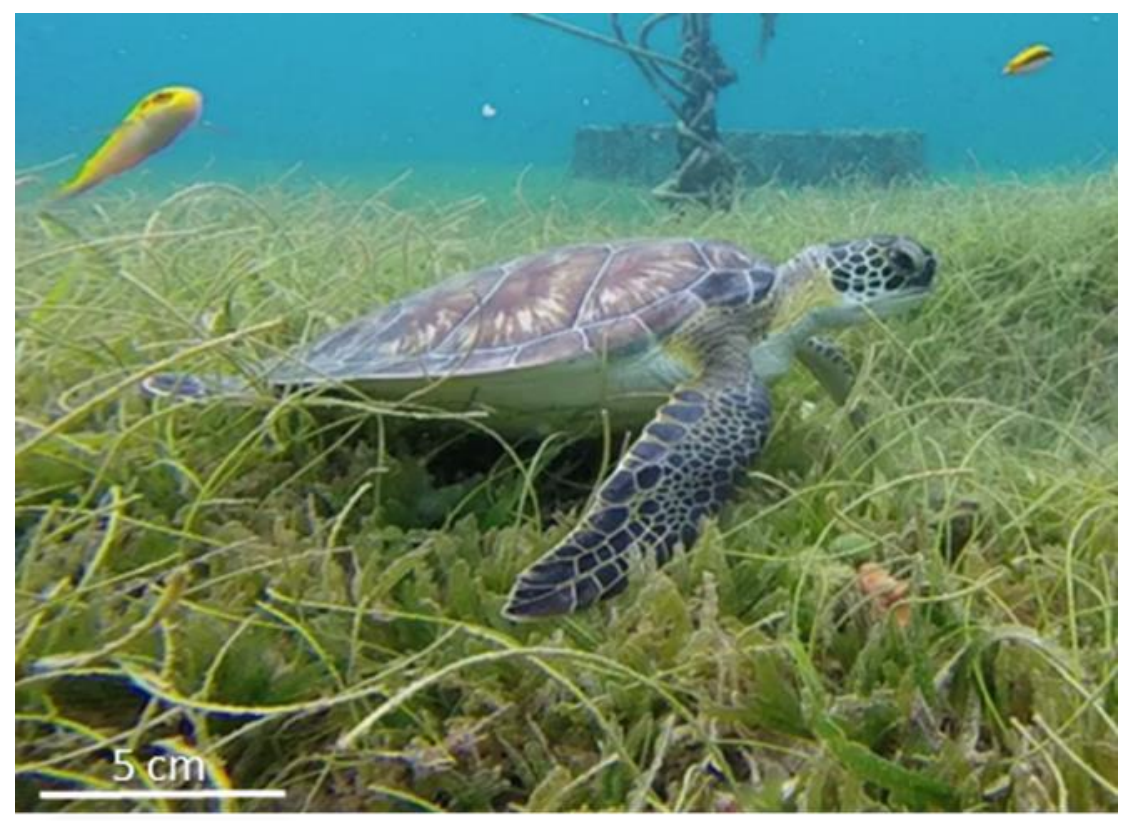

Figure 1. Juvenile green turtle resting in a mixed seagrass meadow in Malendure Bay, Guadeloupe; S. filiforme (native): long cylindrical blades; $H$. stipulacea (invasive): short, densely packed, paddle-shaped blades

Green turtles spend a large part of their life cycle in coastal tropical and subtropical waters, and their selective feeding strategies can structure seagrass community structure (Kelkar et al., 2013). Their diets vary among regions where local populations may be adapted to consume specific forage (e.g., seagrass or algae; Bjorndal, 1980). For example, green turtles off Baja California, Mexico, forage primarily on algae, 
whereas green turtles in The Bahamas forage primarily on the seagrass Thalassia testudinum (Bjorndal, 1980). In another study at Green Island in Queensland, Australia, a juvenile green turtle population appeared to be generalist, eating seagrass and algae, but individuals specialized on one or the other (Fuentes, Lawler and Gyuris, 2006). Similarly, offshore of Western Australia individual green turtles appear to specialize on seagrass, macroalgae, gelatinous macroplankton or a stable mix of these sources (Burkholder $e$ al., 2011). These studies identify dietary compositions, but few studies have looked at the effects of changes in forage species on space use by green turtles. Because green turtles have the potential to exert top-down control and structure ecosystems through their grazing (Lal et al., 2010; Wabnitz et al., 2010), it is important to understand patterns in their habitat use and resource selection.

Understanding the factors that influence foraging distributions, food selection, and ecological impacts of green turtle populations may be particularly critical in areas where there are bottom-up disruptions to ecosystems like the presence of invasive species. Under the conditions of the Enemy Release Hypothesis, invasive species succeed because they are not controlled by natural enemies (Keane and Crawley, 2002; Cogni, 2010). If local grazer populations preferentially feed on native species, they can facilitate invasions, while preferential herbivory on an invader or indiscriminate feeding may slow or minimize the spread of an invasive species. Hawaiian green turtles have incorporated invasive algae and seagrass into their diets, and the proportion of their diets comprised of invasive species has increased with the prevalence of these taxa within their foraging habitats (Russell et al., 2003; Russell and Balazs, 2009, 2015). However, in Caribbean habitats affected by the Halophila stipulacea invasion (Figure 1), green turtles are 
selectively foraging on native seagrasses over the invasive seagrass. In Bonaire, green turtles are facilitating the $H$. stipulacea invasion by selectively feeding on a native seagrass, Thalassia testudinum, which has significantly greater nutrient content than the invasive species (Christianen et al., 2018). However, turtles may not be avoiding invasive seagrasses because of variation in nutrient content. Indeed, green turtles off Guadeloupe positively selected for the native seagrass Syringodium filiforme over the invasive seagrass H. stipulacea, despite similar nutritional quality (Chapter IV).

The hierarchical levels at which resource selection occurs can have important consequences for individual and population energy budgets and structure the impacts of a forager on its ecosystem as well as determines its potential exposure to threats. First order selection is at the level of geographical range, second order selection is at the level of home range, third order is the selection of habitat patches within the home range, and fourth order is the selection of resources within habitat patches (Johnson, 1980; Massé and Côté, 2009).

In the context of the $H$. stipulacea invasion, green turtles are selecting native seagrasses within patches that vary in the proportion of invasive species present (fourth order selection; Chapter IV, Christianen et al. 2018), but whether they select habitats at broader spatial scales (third order selection) in relation to overall seagrass abundance or the abundance of preferred species remains untested. Decision making at the patch level can have consequences beyond those of direct selection and consumption of one species over another including inter- and intra-patch nutrient transport (Pringle, 2018), inter- and intraspecific competition among grazers (e.g., Kleynhans et al. 2011), and indirect effects 
of grazing on other trophic levels (e.g., Waldram, Bond, and Stock 2008; Hays 2005). To assess the effects of the invasive $H$. stipulacea on patch level green turtle foraging habitat use, I tested whether green turtles selected foraging sites depending on 1) variation in nutrient content of seagrasses, 2) spatial variation in the overall abundance of seagrasses, or 3) relative to the abundance of specific types of macrophytes (e.g., native vs invasive seagrasses, macroalgae). I also tested fourth order selection of resources to see if green turtle preference for native seagrasses over the invasive seagrass is consistent across islands.

\section{Methods}

Study sites

The study occurred within three bays along the coasts of Guadeloupe, Martinique, and St. Martin in the French West Indies (FWI; Figure 2). Malendure (16 $10^{\prime} \mathrm{N}, 61^{\circ} 46^{\prime}$ W) is a bay on the western coast of Basse-terre, Guadeloupe. The mouth and widest width of the Bay spans $c a .750 \mathrm{~m}$ and a beach lines $c a .500 \mathrm{~m}$ of the inner coast. GrandeAnse $\left(14^{\circ} 30^{\prime} \mathrm{N}, 61^{\circ} 05^{\prime} \mathrm{W}\right)$ is a bay within Anses d'Arlet, Martinique. The largest bay in our study, Grande Anse is nearly two km wide at its mouth and more than $1.3 \mathrm{~km}$ of beach. Baie-Blanche $\left(18^{\circ} 06^{\prime} \mathrm{N}, 62^{\circ} 59^{\prime} \mathrm{W}\right)$ is a bay on the western coast of Ile Tintimarre, a small uninhabited island in the Saint Martin Nature Reserve. The smallest bay in this study, Baie-Blanche is $c a .650 \mathrm{~m}$ at its mouth, although the survey area extended beyond this, with a $c a .400 \mathrm{~m}$ beach. Native seagrasses found in these bays 
include S. filiforme, T. testudinum, and Halodule wrightii. Island names will henceforth be used to refer to sites.

The first report of rooted H. stipulacea in the Caribbean was in Granada in 2002 (Ruiz and Ballantine, 2004) and has since been documented growing in mixed seagrass patches as far north as Puerto Rico (Ruiz, Ballantine and Sabater, 2017). The seagrass was first documented in Martinique, Guadeloupe, and Saint Martin in 2006, 2010 and 2012, respectively (Willette et al. 2014). The natural gradient of invasive species cover, likely resulting from the temporal invasion gradient, provides an excellent opportunity to study the potential effects of the spread of $H$. stipulacea on grazer habitat use.

We conducted surveys of green turtle and seagrass distributions along belt transects during three field trips to Guadeloupe and Martinique in spring 2016, fall 2016, and spring 2017, and to St. Martin in fall 2016, and spring 2017. Because these sites are popular tourist destinations, and the marine life is highly acclimated to the presence of boats, snorkelers, divers and non-motorized marine craft (e.g., kayaks and paddleboards), animals rarely reacted to our presence in the water facilitating observations of natural foraging behaviors. 


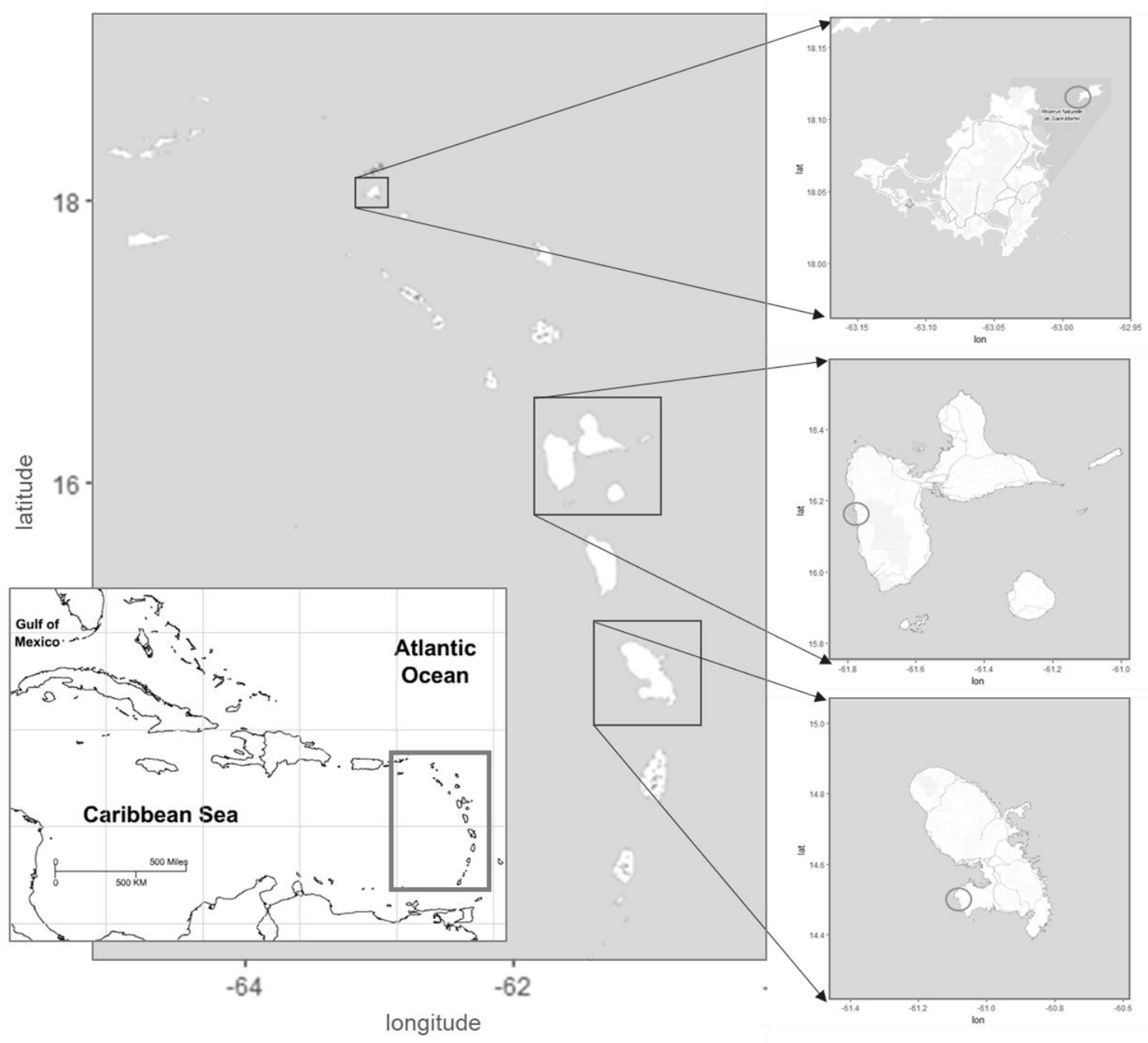

Figure 2. The study was conducted in the Lesser Antilles (left) within the Caribbean Sea (inset). One bay on the islands of St. Martin (top right), Guadeloupe (center right) and Martinique (bottom right) were selected based on the presence of turtles and mixed beds of invasive and native seagrasses.

\section{Habitat classification}

I divided each study area into $100 \mathrm{~m}$ x $100 \mathrm{~m}$ cells using a vector grid layer in QGIS version 2.18.11 (QGIS Development Team, 2018; Figure 3). Data collected within each hectare allowed us to further define the patches by assigning habitat values to each for a quantitative analysis. Using the "join attributes" function in QGIS, I extracted all 
survey data [i.e., macrophyte abundance, sampling effort (Figure 3), and turtle sightings] per cell to calculate total and average values per cell. Only cells with data were used in the respective analyses.
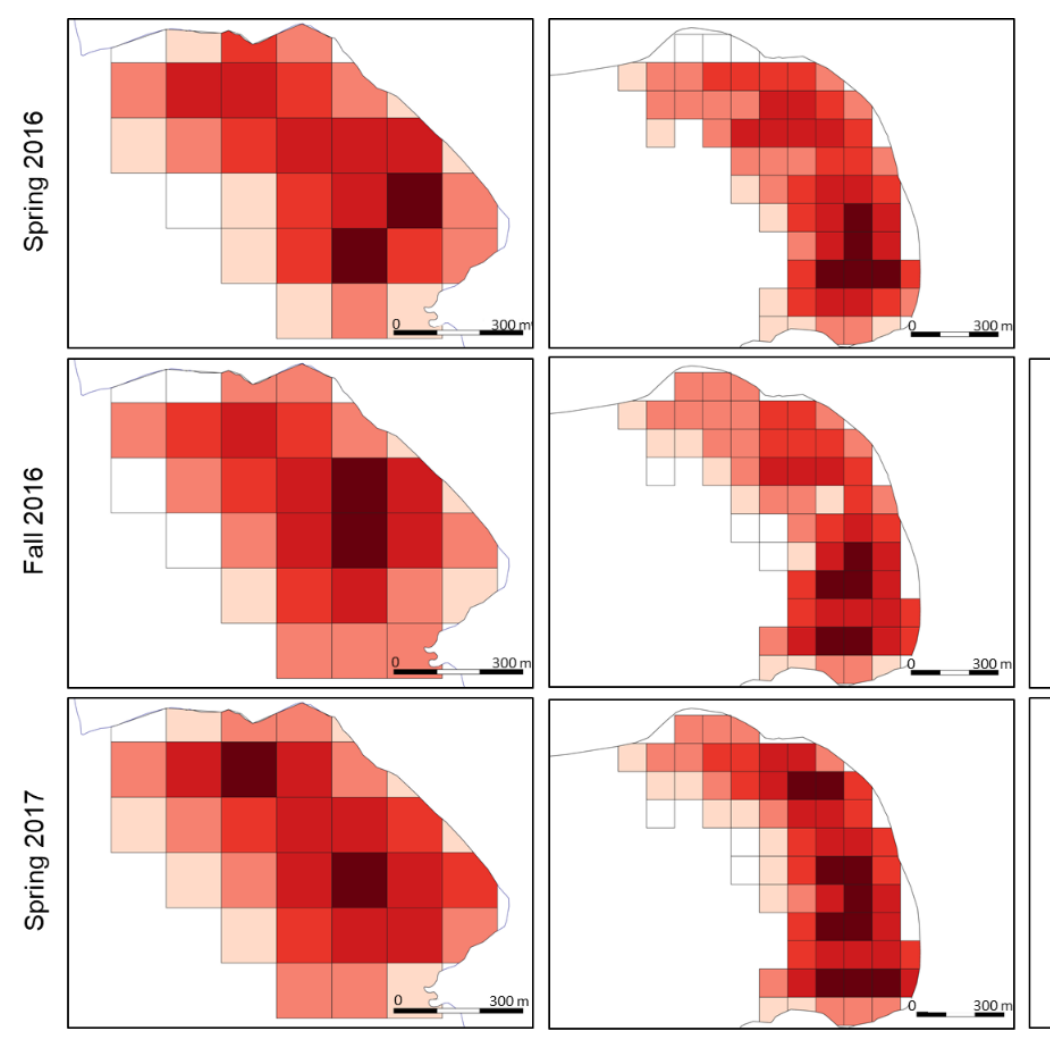

Legend

Sampling effort (ha)

$\square>0.00-0.55$

$\square>0.55-1.65$

$\square$
$>1.55-1.65$
$>$

$>1.65-3.08$
$>3.08-4.36$

- $>4.36-5.60$

Figure 3. Survey effort in ha surveyed per site per sampling event. Cells on the grid are $100 \mathrm{~m} \times 100 \mathrm{~m}$. Color breakpoints were autogenerated by QGIS

\section{Forage availability}

Detailed surveys of the seagrass community were conducted in each site across

multiple field sampling events. Sampling plans evolved as the study progressed (Table 1) 
from intense haphazard surveys of Guadeloupe in 2016 (112 points sampled) to predetermined $100 \mathrm{~m}$ grid points at all sites.

Table 1. Number of sampling plots and methods for macrophyte abundance and nutrient content collection; dashes indicate no data collection

\begin{tabular}{|l|c|c|c|c|c|c|}
\hline & \multicolumn{2}{|c|}{ Spring 2016 } & \multicolumn{2}{c|}{ Fall 2016 } & \multicolumn{2}{c|}{ Spring 2017 } \\
\cline { 2 - 7 } & Abundance & Nutrients & Abundance & Nutrients & Abundance & Nutrients \\
\hline Guadeloupe & $\begin{array}{c}122, \\
\text { haphazard }\end{array}$ & - & - & $\begin{array}{c}12, \\
\text { haphazard }\end{array}$ & $\begin{array}{c}23, \\
100 \mathrm{~m} \text { grid }\end{array}$ & $\begin{array}{c}11, \\
\text { haphazard }\end{array}$ \\
\hline Martinique & $\begin{array}{c}10, \\
\text { haphazard }\end{array}$ & - & - & $\begin{array}{c}19, \\
\text { haphazard }\end{array}$ & $\begin{array}{c}55, \\
100 \mathrm{~m} \text { grid }\end{array}$ & $\begin{array}{c}14, \\
\text { grid points }\end{array}$ \\
\hline St. Martin & - & - & $\begin{array}{c}72, \\
30 \mathrm{~m} \text { grid }\end{array}$ & $\begin{array}{c}7, \\
\text { grid points }\end{array}$ & $\begin{array}{c}25, \\
100 \mathrm{~m} \text { grid }\end{array}$ & $\begin{array}{c}7, \\
\text { grid points }\end{array}$ \\
\hline
\end{tabular}

At each point in each sampling event, two observers, either freediving or on SCUBA estimated the abundance of each species present within four $50 \mathrm{~cm} \times 50 \mathrm{~cm}$ quadrats. Each macrophyte species was assigned a score according to the Braun-Blanquet scale for rapid vegetation assessments (Table 2) (Fourqurean et al., 2001). At each sampling point, each observer estimated abundance of each species with two quadrats for a total of 4 assessments per point. From the mean of the four assessment scores I calculate density as the mean score from the four quadrats for each species present at each sampling point. The Braun-Blanquet method, commonly used to assess the abundance of seagrass and macroalgae, is efficient, highly repeatable, non-destructive and minimizes observer differences (Fourqurean et al., 2001). 
Table 2. Braun-Blanquet abundance scores of each macrophyte species; the score for each sampling point is the average of scores given to each species based on this scale within four quadrats at each point; reproduced from (Fourqurean et al., 2001)

\begin{tabular}{cl}
\hline Score & Cover \\
\hline 0 & Taxa absent from quadrat \\
0.1 & Taxa represented by a solitary shoot, $<5 \%$ cover \\
0.5 & Taxa represented by a few $(<5)$ shoots, $<5 \%$ cover \\
1 & Taxa represented by many $(>5)$ shoots, $<5 \%$ cover \\
2 & Taxa represented by many $(>5)$ shoots, $5-25 \%$ cover \\
3 & Taxa represented by many $(>5)$ shoots, $25-50 \%$ cover \\
4 & Taxa represented by many $(>5)$ shoots, $50-75 \%$ cover \\
5 & Taxa represented by many $(>5)$ shoots, $75-100 \%$ cover \\
\hline
\end{tabular}

Nutrient content analyses

I collected $c a .40$ seagrass leaves or equivalent macroalgae biomass of each macrophyte species for nutrient content analysis at haphazardly or grid selected plots (Table 1) in fall 2016 and spring 2017. The samples were collected by hand either while freediving or on SCUBA, placed in labeled plastic sandwich bags, and refrigerated until they could be processed and transported to Florida International University for analysis. Samples were cleaned of epiphytes using a straight-edge razor and dried in a food-grade dehydrator for a minimum of 24 hours within 48 hours of collection. After drying, samples were crushed using a mortar and pestle and stored in airtight vials for transport. $\mathrm{C}$ and $\mathrm{N}$ were measured using a CE Flash 1112 elemental analyzer using standard procedures, and total $\mathrm{P}$ was analyzed colorimetrically following modified methods from Solórzano and Sharp (1980) on a Shimadzu UV-2101PC spectrophotometer. 


\section{Turtle abundance and distributions}

Each bay was divided into three sections of similar area using identifiable landmarks along the beach as boundary markers. Transects originated from haphazard locations along the beach, within three strata to ensure relatively uniform coverage of the bay. To avoid pseudoreplication, I did not immediately repeat transects. Additionally, sections within each site were surveyed equally in 2-hour time bins from 0700-1700 when there was adequate sunlight to conduct surveys. Two observers on snorkel and tethered to each other with a $15 \mathrm{~m}$ rope (see Roos et al. 2005) swam transects perpendicular to the beach to survey turtles and seagrasses (Figure 2). Only turtles spotted within the transects (between observers) were counted. When a turtle was spotted, observers signaled each other with two pulls on the line between them. For each sighting the location using a towed handheld GPS (Garmin® GPSmap 78), turtle behavior (foraging, resting, or traveling), forage species consumed (when possible), and an estimate of percent cover of all macrophyte species present were recorded. Transects were terminated when visibility of the benthos mid-distance from each observer was too poor to identify macrophyte species, after which observers swam perpendicular to the beach until the return transect would not overlap with the one just completed.

Using the Vector grid feature in QGIS 2.18, I divided each site into one-hectare grid cells. The join attribute feature allowed me to assign cell identification numbers to all data within each cell (Figure 2). Individual transects crossed multiple cells, so survey effort per cell was calculated as the sum of the area of transect segments occurring within each cell. Macrophyte abundance and nutrients were averaged if more than one survey 
point fell within a cell. Turtle sightings per transect segment per cell were summed. I calculated densities (number of animals $* \mathrm{ha}^{-1}$ ) using:

$$
D_{i}=\frac{n^{i}}{w * L}
$$

where $n^{i}$ is the number of individuals detected within a transect segment, $w$ is the transect width $(15 \mathrm{~m})$ and $L$ is the length of the transect calculated using start and end waypoints recorded with GPS.

Data analysis

All statistical tests were performed using R software (R Core Team, 2016). To test for habitat differences within and among sites and sampling events, I used KruskalWallis and Wilcoxon sign rank tests for differences in seagrass abundance, richness, and nutrient content (CNP). Tests did not include macroalgae, because no turtles were observed foraging on algae during any of the surveys for my study.

I used a mixed-effects model with sampling event as the random effect and forage abundance variables to model predictions depending on forage abundance of each species and depth as the fixed effects to model effects of habitat variables on green turtle distributions at each site. No turtles were observed foraging on macroalgae, so it was excluded from the analyses. Cells with no forage abundance data were not included. Sampling points and sample sizes were not consistent across sampling events, so caution must be used in the interpretation of the temporal comparisons and data were pooled for site comparisons. Because forage nutrient content data were not collected consistently 
during sampling events when forage abundance data were collected, they were not included. I used a model selection table (R Package 'AICcmodavg', function = aictab, Mazerolle, 2017) of models using different combinations and interactions of abundance variables for stepwise model selection using Akaike information criterion (AIC) and Akaike weights. Models that did not converge were not included in the table. Because of the differences among sites in resource availability, model selection for each site was done independently. The fixed effects included in the models also varied because of resource availability. Seagrass species observed within less than five cells across all sampling events were excluded in the analysis for the respective site.

I used the R package adehabitatHS (Calenge, 2006) design III selectivity analysis to test the effects of species composition (resource availability) on foraging (resource use) for each individual turtle. Because of the few observations of foraging on $H$. wrightii, unknown species and of marine debris and animal matter (i.e., ctenophores and bivalve shells), were not included in analyses. No turtles were observed foraging on macroalgae, so it was also excluded from the analysis. Weighted presence $(0=$ absent, 1 $=$ present, $2=$ dominant species present) of each forage species was used as the resource availability input, and the identifiable selection of a forage species was used as the resource use input.

Assuming uniform use of habitats as the null hypothesis, resource use was tested for the population and for individuals using Chi-square goodness-of-fit tests. I calculated Manly's selection ratios (Wi, Manly et al., 2002) with Bonferroni confidence intervals with available resources defined for each animal by the categories $H$. stipulacea $(\mathrm{Hs}), S$. 
filiforme (Sf), and T. testudinum (Tt) (Calenge, 2015). Use of a resource was defined by the visual observation of the animal feeding on a seagrass species. Ratios (resource use to resource availability) greater than 1 indicate selection and less than 1 indicate avoidance. Ratios near 1 or confidence intervals for the population overlapping 1 suggest no selectivity.

\section{Results}

Forage availability

Guadeloupe

In Spring 2016, native seagrasses T. testudinum and S. filiforme were found at six (4.9\%) and $75(61.5 \%)$ of 122 haphazard sampling points, respectively. One native seagrass, $H$. wrightii, was not found at any site. The invasive $H$. stipulacea was found at $118(96.7 \%)$ sites. Calcareous algae, other green algae, and red and brown algae were found at $70(57.4 \%), 12(9.8 \%)$, and $74(60.7 \%)$ sites, respectively, but at very low abundances (Figure 4).

In Spring 2017, two native seagrasses (T. testudinum and $H$. wrightii) were not found at any sites while S. filiforme occurred at 9 of 23 (39.1\%;) 100-m grid sampling points. The invasive $H$. stipulacea was found at $16(69.6 \%)$ sites. Calcareous algae were found at $4(17.4 \%)$ sites at very low abundances (Figure 4$)$ but other green algae, and red and brown algae were not observed at any site. 
Mean seagrass richness per site was significantly greater in Spring 2016 than Spring 2017 ( $W=1886.5, P=0.003)$. Mean invasive abundance was significantly greater than the sum of all native seagrass abundance scores per plot in both Spring 2016 $(W=12914, P<0.0001)$ and Spring $2017(W=399.5, P=0.002)$. Mean $H$. stipulacea abundance did not change significantly between sampling events $(W=1480.5, P=0.68)$, however, mean $S$. filiforme (the only native seagrass observed at survey points during both sampling events decreased significantly from 2016 to 2017 ( $W=399.5, P=0.002)$.

Across both sampling events, S. filiforme was the most abundant native seagrass and occurred at $57.9 \%$ of the 145 total sampling points. The invasive $H$. stipulacea occurred at $92.4 \%$ of the points. The mean Braun-Blanquet score for $H$. stipulacea was significantly greater than the score for $S$. filiforme $(W=3146.5, P=<0.0001)$. On average, $H$. stipulacea was found at densities $25-50 \%$ and as high as $100 \%$. S. filiforme was found at densities less than 5\% and never more than 50\% (Table 3). 

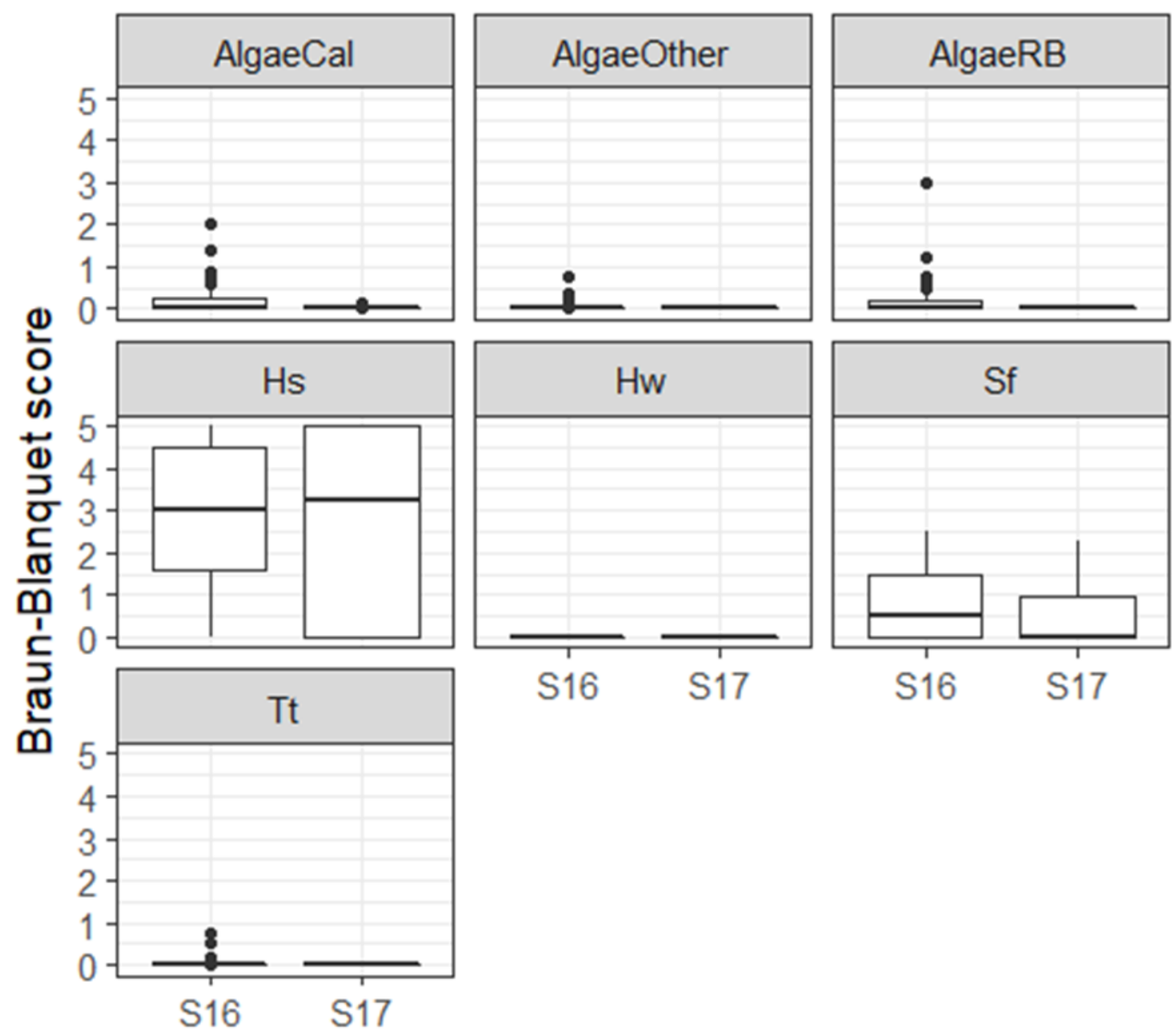

\section{Season}

Figure 4. Braun-Blanquet abundance scores for Spring 2016 (S16) and Spring 2017 (S17) from Guadeloupe. The midline of the boxplot is the median, upper and lower limits of the box represent the $75^{\text {th }}$ and $25^{\text {th }}$ percentile, whiskers extend to minimum and maximum values except for data exceeding 1.5 times the interquartile range, which are displayed as dots (possible outliers). 


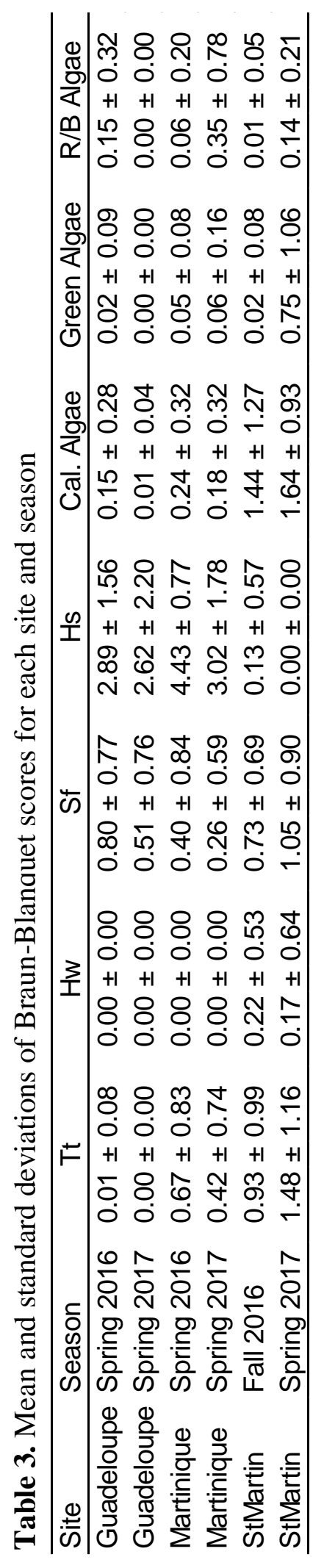




\section{Martinique}

In Spring 2016, native seagrasses T. testudinum and S. filiforme were found at 7 (70.0\%), and $2(20.0 \%)$ of 10 haphazard sampling points, respectively. The native $H$. wrightii was not found at any site. The invasive $H$. stipulacea was found at all 10 points. Calcareous algae, other green algae, and red and brown algae were found at $5(50.0 \%), 5$ (50.0\%), $1(10.0 \%)$ site, respectively, but at very low abundances (Figure 5).

In Spring 2017, native seagrasses T. testudinum and S. filiforme were found at 24 (43.6\%) and $11(20.0 \%)$ of 55 100-m grid sampling points, respectively. One native seagrass, $H$. wrightii, was not found at any site. The invasive $H$. stipulacea was found at 46 sites $(83.6 \%)$. Calcareous algae, other green algae, and red and brown algae were found at $26(47.3 \%), 11(20.0 \%), 17(30.9 \%)$, respectively, but at very low abundances at most plots (Figure 5). As a consequence of low sample size in 2016, I did not do a statistical comparison across sampling events.

Across sampling events, $T$. testudinum occurred at $47.7 \%$ of the 65 total sampling points, S. filiforme at $20.0 \%$ of the points, and the invasive $H$. stipulacea at $86.2 \%$ of the points. T. testudinum had a greater mean Braun-Blanquet score than $S$. filiforme $(W=$ 1611.5, $P=0.006)$, and $H$. stipulacea had higher mean abundance scores, usually occurring at densities greater than $50 \%$ and up to $100 \%$, than both $T$. testudinum $(W=$ 521.5, $P<0.0001)$ and $S$. filiforme $(W=399.5,<0.0001) . T$. testudinum and $S$. filiforme were each found on average at densities less than 5\% and never greater than $50 \%$ (Table $3)$. 


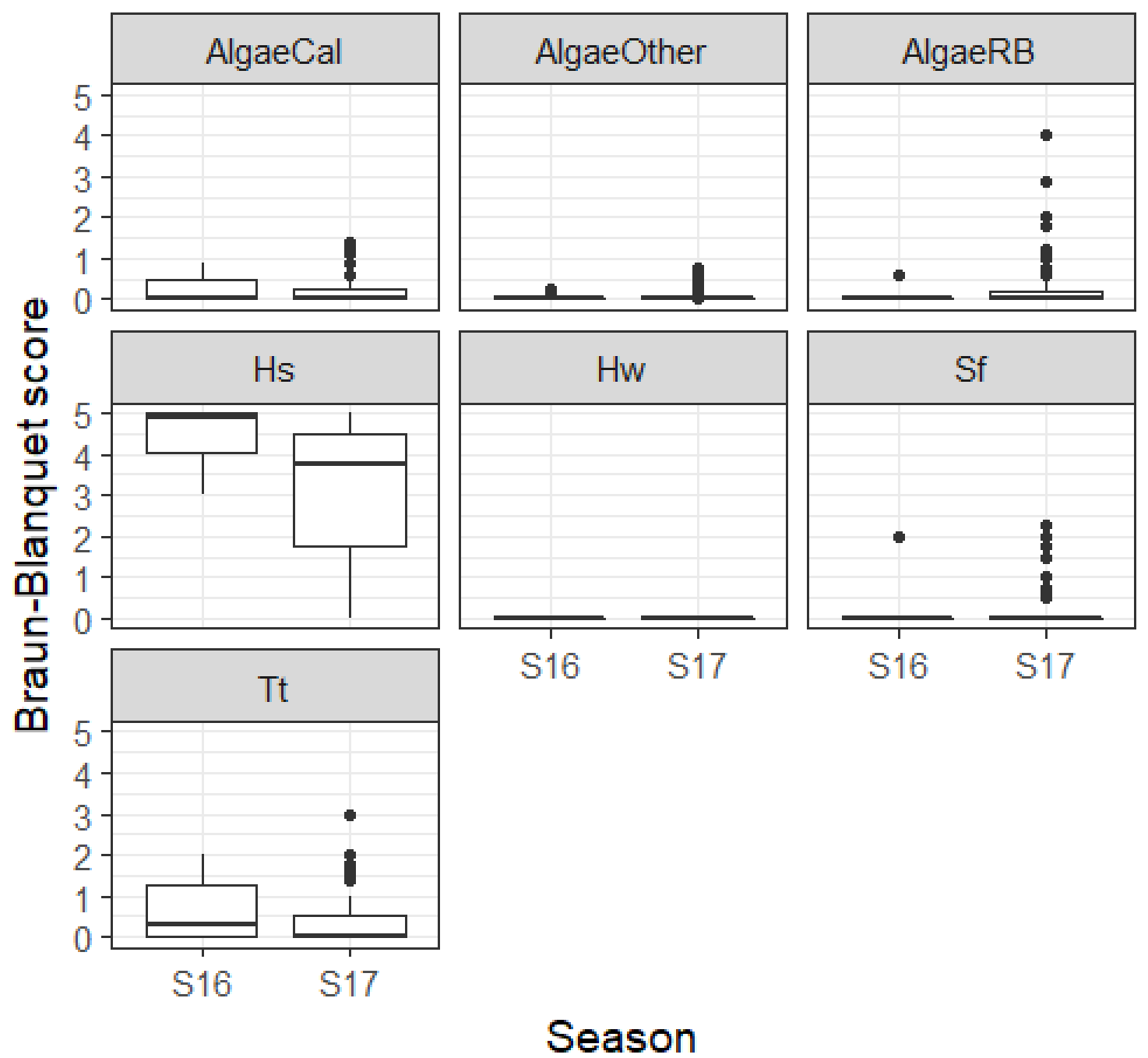

Figure 5. Braun-blanquet abundance scores for macrophytes of Martinique Spring 2016 (S16) and Spring 2017 (S17). The midline of the boxplot is the median, upper and lower limits of the box represent the $75^{\text {th }}$ and $25^{\text {th }}$ percentile, whiskers extend to minimum and maximum values except for data exceeding 1.5 times the interquartile range, which are displayed as dots (possible outliers).

\section{$\underline{\text { St. Martin }}$}

In Fall 2016, native seagrasses T. testudinum, S. filiforme, and $H$. wrightii were found at $40(55.6 \%), 41(56.9 \%)$, and 15 (20.8\%) of 7230 -m grid sampling points, respectively. The invasive $H$. stipulacea was found at $4(5.6 \%)$. Calcareous algae, other 
green algae, and red and brown algae were found at 50 (69.4\%), 11 (15.3\%), $2(2.8 \%)$, respectively. Calcareous green algae were the most abundant macrophyte within plots ( $W$ $=4213, P=<0.0001)($ Figure 6, Table 3$)$.

In Spring 2017, native seagrasses T. testudinum, S. filiforme, and $H$. wrightii were found at $22(88.0 \%), 16(64.0 \%)$, and $2(8.0 \%)$ of $25100-\mathrm{m}$ grid sampling points, respectively. The invasive $H$. stipulacea was not found at the 2017 sampling points, but it is found in a small (c.a. $100 \mathrm{~m}^{2}$ ) monospecific and along the edges of some mixed seagrass beds in the northern section of the bay. Calcareous algae, other green algae, and red and brown algae were found at $23(0.92 \%), 12(48.0 \%), 10$ (40.0\%), respectively. Calcareous green algae were also the most abundant macroalgae within plots compared to the sum of all other macroalgae $(W=436.5, P=0.02)$ (Figure 6 , Table 3$)$.

Mean seagrass richness did not differ between Spring 2016 and Spring 2017 ( $W=$ $819, P=0.46)$. Mean sum of all algae and mean sum of native seagrass abundances did not differ in either Fall $2016(W=280, P=0.53)$ nor Spring $2017(W=2155.5, P=$ 0.08). Mean sum of all algae was significantly greater in Spring 2017 than Fall 2016 ( $W$ $=657.5, P=0.04)$, but did the mean abundances of native seagrasses $S$. filiforme $(W=$ $700.5, P=0.09)$ and $T$. testudinum $(W=681.5, P=0.06)$ did not differ between the two sampling events.

Across sampling events, $T$. testudinum occurred at $63.9 \%$ of the 97 total sampling points, S. filiforme at $58.8 \%$ of the points, and $H$. wrightii at $17.5 \%$ of the points. Mean Braun-Blanquet abundance scores were not significantly different for $T$. testudinum and S. filiforme ( $W=4055, P=0.09)$, however, $H$. wrightii had lower mean abundance 
scores than both $T$. testudinum $(W=7068, P<0.0001)$ and $S$. filiforme $(W=6737$, $<$ 0.0001). On average, T. testudinum was found at densities 5-25\% and up to $100 \%, S$. filiforme and $\mathrm{H}$. wrightii were each found at densities less than $5 \%$ on average and up to 50\% (Table 3). In 2016 H. stipulacea was found at densities up to $75 \%$.
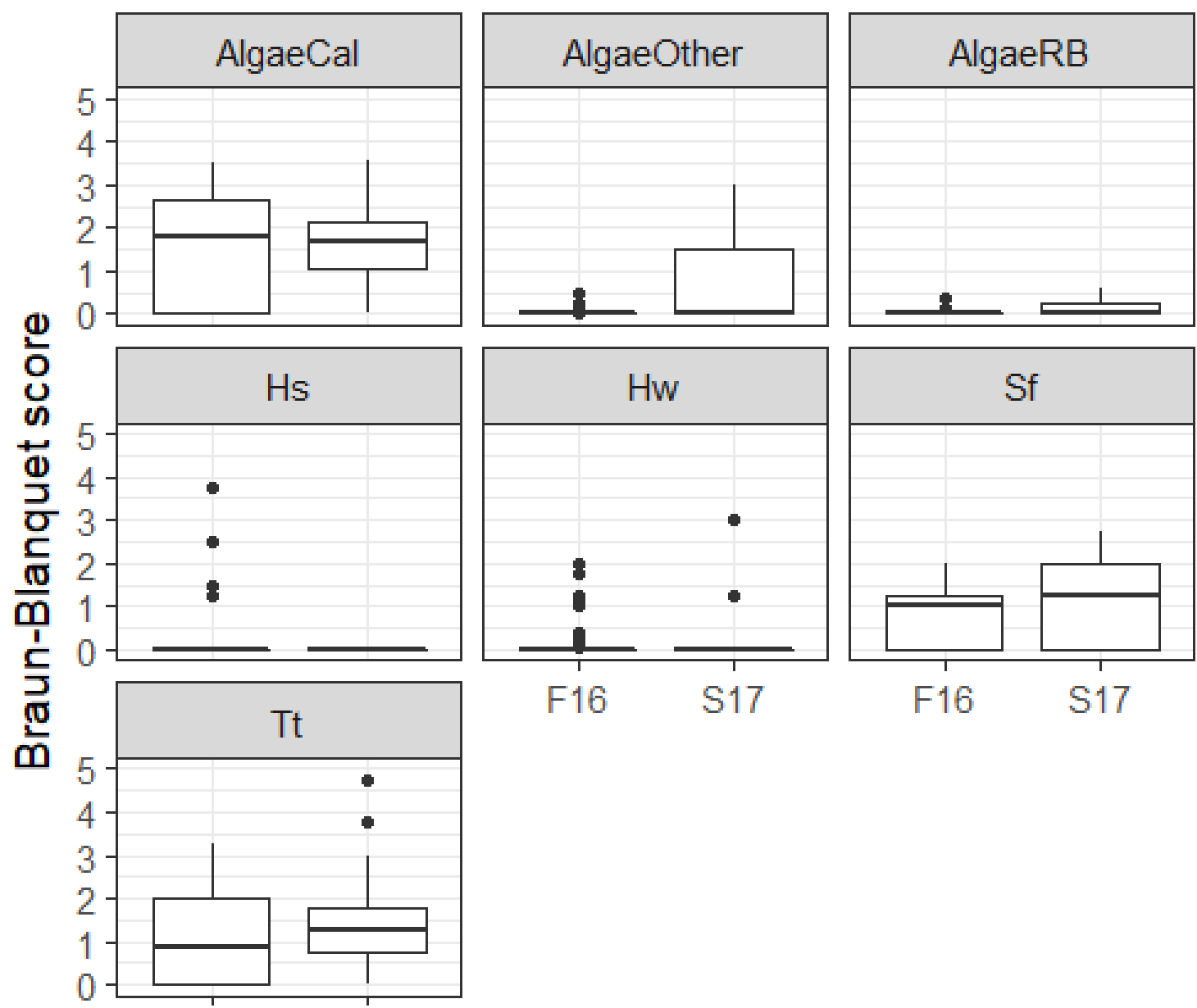

F16

S17
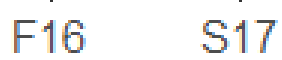

F16 S17

\section{Season}

Figure 6. Braun-blanquet abundance scores for macrophytes of St. Martin Fall 2016 (F16) and Spring 2017 (S17). The midline of the boxplot is the median, upper and lower limits of the box represent the $75^{\text {th }}$ and $25^{\text {th }}$ percentile, whiskers extend to minimum and maximum values except for data exceeding 1.5 times the interquartile range, which are displayed as dots (possible outliers). 


\section{Forage nutrient content}

Guadeloupe

Nitrogen content did not differ between the invasive $H$. stipulacea and most abundant native seagrass $S$. filiforme ( $W=213, P=0.66$ ). The native seagrasses $H$. wrightii and T. testudinum were only found at three and two sampling plots, respectively, across the three sampling events, so they were not included in analyses. No turtles were observed foraging on algae during this study, so macroalgae were also excluded. Mean C content was $c a .9 \%$ greater in $S$. filiforme than $H$. stipulacea $(W=121, P=0.01$, Table 4). Total P content did not differ between $H$. stipulacea and $S$. filiforme $(W=326.5, P=$ 0.08). The C:N did not differ between $H$. stipulacea and $S$. filiforme $(W=227, P=0.65)$, mean C:P was $27 \%$ greater in S. filiforme than $H$. stipulacea $(W=117, P=0.01)$, and $\mathrm{N}: \mathrm{P}$ did not differ between $H$. stipulacea and S. filiforme $(W=151, P=0.06)$. The C:N and C:P ratios for all seagrasses were below Redfield ratios suggesting that the site was a nutrient rich site (Table 4, Figure 7).

Table 4. C, N, P content and their ratios $\pm \mathrm{SD}$ of calcareous green algae (ACG), $H$. stipulacea $(\mathrm{Hs}), H$. wrightii $(\mathrm{Hw})$, S. filiforme (Sf), T. testudinum (Tt) off Guadeloupe

\begin{tabular}{lccccc}
\hline & ACG & Hs & Hw & Sf & Tt \\
\hline $\mathrm{N}$ & $1.2 \pm 0.4$ & $2.0 \pm 0.6$ & $2.5 \pm 0.4$ & $2.0 \pm 0.3$ & $1.9 \pm 0.5$ \\
$\mathrm{C}$ & $21.9 \pm 2.1$ & $32.2 \pm 1.8$ & $39.4 \pm 1.1$ & $35.2 \pm 4.2$ & $38.3 \pm 2.1$ \\
$\mathrm{P}$ & $0.05 \pm 0.01$ & $0.20 \pm 0.05$ & $0.29 \pm 0.15$ & $0.18 \pm 0.03$ & $0.17 \pm 0.01$ \\
$\mathrm{CN}$ & $19.0 \pm 4.1$ & $16.9 \pm 3.2$ & $16.2 \pm 2.1$ & $18.2 \pm 2.1$ & $20.6 \pm 4.1$ \\
$\mathrm{CP}$ & $474.5 \pm 127.5$ & $167.3 \pm 46.0$ & $156.2 \pm 60.9$ & $212.0 \pm 52.7$ & $225.8 \pm 6.2$ \\
$\mathrm{NP}$ & $25.6 \pm 6.4$ & $10.1 \pm 3.1$ & $9.9 \pm 4.5$ & $11.8 \pm 3.3$ & $11.2 \pm 1.9$ \\
\hline
\end{tabular}



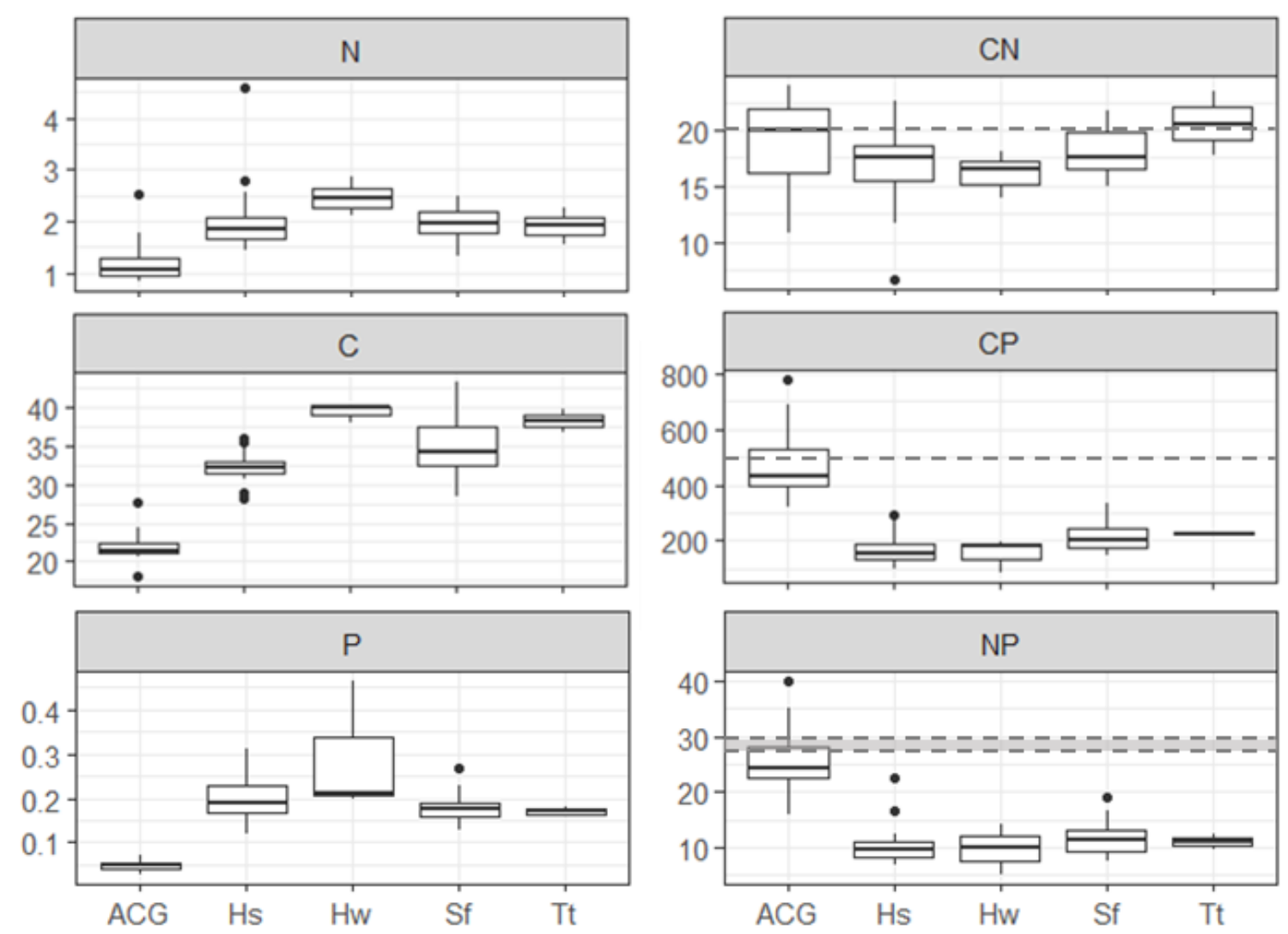

\section{Species}

Figure 7. Elemental composition of macrophytes off Guadeloupe; Left (top-bottom): C, $\mathrm{N}$, and $\mathrm{P}$ content of calcareous green algae (ACG), H. stipulacea $(\mathrm{Hs})$, H. wrightii $(\mathrm{Hw})$, S. filiforme (Sf), T. testudinum (Tt); Right: Ratios of C:N, C:P, and N:P for each species; the dashed lines represent the seagrass Redfield ratio

$\underline{\text { Martinique }}$

In contrast to patterns observed off Guadeloupe, there was considerable interspecific variation in nutrient content among seagrass species of Martinique (Table 5). Mean N content was $22 \%$ greater in the invasive $H$. stipulacea than native $S$. filiforme and $14 \%$ greater in T. testudinum than H. stipulacea (Table 6). Mean N content was 39\% 
greater in $T$. testudinum than $S$. filiforme. The native seagrass, $H$. wrightii, was only found at one sampling plot, across the three sampling events, so it was not included in analyses. Mean C content was $16 \%$ greater in T. testudinum than $\mathrm{H}$. stipulacea and $17 \%$ greater than in S. filiforme (Table 6), but not different between H. stipulacea and S. filiforme. Mean P content was 45\% greater in H. stipulacea than in S. filiforme, and 25\% greater than in T. testudinum. Mean P content was $16 \%$ greater in T. testudinum than in $S$. filiforme (Table 6). The C:N of S. filiforme was $23 \%$ and $21 \%$ greater than $H$. stipulacea and T. testudinum, respectively. The C:P was $42 \%$ greater in both $T$. testudinum and $S$. filiforme than in H. stipulacea (Table 6). The N:P in S. filiforme was $17 \%$ greater than in H. stipulacea, and $20 \%$ and $40 \%$ greater in T. testudinum than in S. filiforme and $H$. stipulacea, respectively (Table 6). The C:N and C:P ratios for all seagrasses were below Redfield ratios, suggesting that those habitats are nutrient rich, and the low N:P ratio suggests that Martinique site is limited by $\mathrm{N}$ (Table 6, Figure 8). 
Table 5. Wilcoxon rank sum test results of nutrients among seagrass species off Martinique; Significance codes: $0^{\text {'***' }}, 0.001^{\text {'**', }}, 0.01^{\text {'*', }}$, $0.05^{\prime}$ '

\begin{tabular}{|c|c|c|c|c|c|}
\hline \multicolumn{6}{|c|}{ Martinique } \\
\hline Variable & Species & 1 Species 2 & $W$ & $P$-value & \\
\hline $\mathrm{N}$ & $\mathrm{Hs}$ & $\mathrm{Tt}$ & 141.5 & 0.0173 & $3 *$ \\
\hline$N$ & Hs & $\mathrm{Sf}$ & 249.0 & 0.0034 & $4 * *$ \\
\hline$N$ & $\mathrm{Tt}$ & Sf & 148.0 & 0.0001 & $1 * * *$ \\
\hline C & Hs & Sf & 203.0 & 0.1514 & \\
\hline$C$ & Hs & $\mathrm{Tt}$ & 0.0 & $<0.0001$ & $1 * * *$ \\
\hline$C$ & $\mathrm{Tt}$ & Sf & 160.0 & $<0.0001$ & $1 * * *$ \\
\hline$P$ & Hs & Sf & 269.0 & $<0.0001$ & $1 * \star \star$ \\
\hline$P$ & Hs & $\mathrm{Tt}$ & 390.5 & 0.0002 & $2^{* * *}$ \\
\hline$P$ & $\mathrm{Tt}$ & Sf & 133.0 & 0.0041 & ** \\
\hline $\mathrm{CN}$ & $\mathrm{Hs}$ & Sf & 39.0 & 0.0002 & $2 * \star \star$ \\
\hline $\mathrm{CN}$ & Hs & $\mathrm{Tt}$ & 232.0 & 0.7300 & \\
\hline $\mathrm{CN}$ & $\mathrm{Tt}$ & $\mathrm{Sf}$ & 28.0 & 0.0050 & ** \\
\hline $\mathrm{CP}$ & $\mathrm{Hs}$ & Sf & 21.0 & $<0.0001$ & $1 * * *$ \\
\hline $\mathrm{CP}$ & $\mathrm{Hs}$ & $\mathrm{Tt}$ & 28.0 & $<0.0001$ & $1 * * *$ \\
\hline $\mathrm{CP}$ & $\mathrm{Tt}$ & Sf & 80 & 1.0000 & \\
\hline NP & Hs & Sf & 68.0 & 0.0122 & 2 * \\
\hline NP & Hs & $\mathrm{Tt}$ & 26.0 & $<0.0001$ & $1 * * *$ \\
\hline NP & $\mathrm{Tt}$ & $\mathrm{Sf}$ & 134.0 & 0.0034 & $4^{* *}$ \\
\hline
\end{tabular}

Table 6. C, N, P content and their ratios \pm SD of calcareous green algae (ACG), other algae (AO), H. stipulacea $(\mathrm{Hs}), H$. wrightii $(\mathrm{Hw})$, S. filiforme $(\mathrm{Sf})$, T. testudinum $(\mathrm{Tt})$ off Martinique

\begin{tabular}{lcccccc}
\hline & ACG & AO & Hs & Hw & Sf & Tt \\
\hline $\mathrm{N}$ & $1.5 \pm 0.7$ & $2.1 \pm 0.9$ & $1.9 \pm 0.4$ & $3.0 \pm \mathrm{NA}$ & $1.6 \pm 0.3$ & $2.2 \pm 0.3$ \\
$\mathrm{C}$ & $21.3 \pm 4.4$ & $32.2 \pm 9.1$ & $30.7 \pm 3.3$ & $39.8 \pm \mathrm{NA}$ & $30.6 \pm 1.6$ & $35.7 \pm 1.2$ \\
$\mathrm{P}$ & $0.07 \pm 0.04$ & $0.10 \pm 0.05$ & $0.21 \pm 0.04$ & $0.34 \pm \mathrm{NA}$ & $0.14 \pm 0.02$ & $0.17 \pm 0.02$ \\
$\mathrm{CN}$ & $16.8 \pm 5.5$ & $17.1 \pm 4.8$ & $16.1 \pm 2.0$ & $13.2 \pm \mathrm{NA}$ & $19.8 \pm 3.4$ & $16.4 \pm 2.3$ \\
$\mathrm{CP}$ & $393.5 \pm 134.6$ & $356.1 \pm 138.1$ & $150.3 \pm 33.3$ & $118.0 \pm \mathrm{NA}$ & $213.5 \pm 22.6$ & $213.4 \pm 19.4$ \\
$\mathrm{NP}$ & $25.7 \pm 9.4$ & $20.8 \pm 5.3$ & $9.4 \pm 1.8$ & $8.9 \pm \mathrm{NA}$ & $10.9 \pm 1.5$ & $13.1 \pm 1.6$ \\
\hline
\end{tabular}



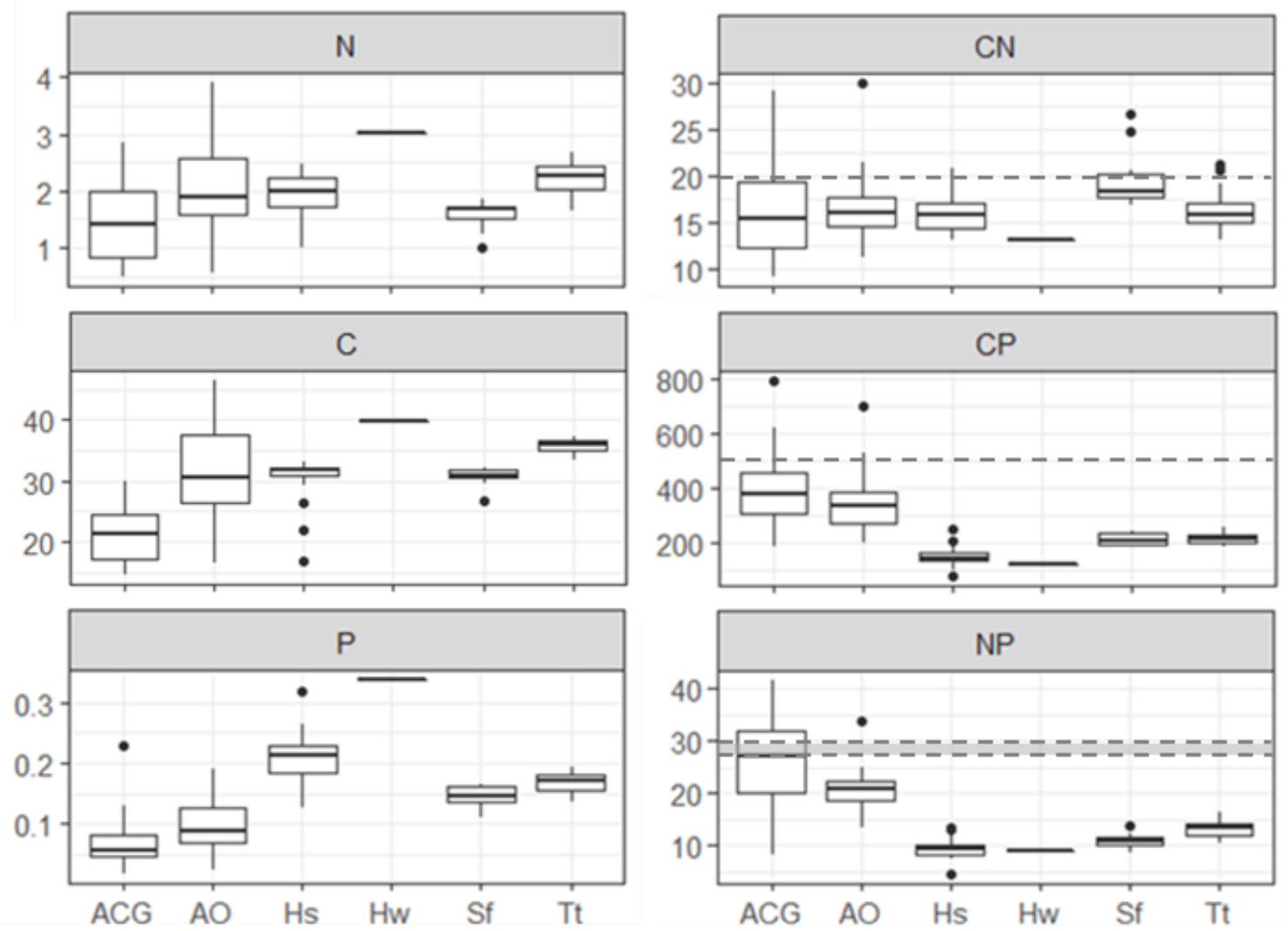

\section{Species}

Figure 8. Elemental composition of macrophytes off Martinique; Left (top-bottom): C, $\mathrm{N}$, and $\mathrm{P}$ content of calcareous green algae (ACG), other algae (AO), H. stipulacea $(\mathrm{Hs})$, $H$. wrightii (Hw), S. filiforme (Sf), T. testudinum (Tt); Right: Ratios of C:N, C:P, and N:P for each species; the dashed lines represent the seagrass Redfield ratio

$\underline{\text { St. Martin }}$

Mean $\mathrm{N}$ content was $36 \%$ greater in T. testudinum and $43 \%$ greater $H$. wrightii than in S. filiforme (Table 7). Mean C content was $9 \%$ greater in T. testudinum and 12\% greater $H$. wrightii than in S. filiforme. Mean P content was $35 \%$ greater in $T$. testudinum than in S. filiforme. H. stipulacea was only found at two sampling plots, across the three 
sampling events, so it was not included in analyses. C:N was $28 \%$ greater in S. filiforme than in $H$. wrightii. The C:P in S. filiforme was $27 \%$ and $23 \%$ greater than in $H$. wrightii and T. testudinum, respectively. The N:P did not differ among seagrasses. The C:N ratio was not consistent among seagrasses, and C:P ratios for all seagrasses were below Redfield ratios, suggesting that St. Martin site is a nutrient rich habitat. The low N:P ratio in seagrasses suggests that $\mathrm{N}$ is the limiting nutrient (Table 8, Figure 9).

Table 7. Wilcoxon rank sum test results of nutrients among seagrass species off St. Martin; Significance codes: $0^{\text {'***', }} 0.001^{\text {'**', }}, 0.01^{\text {'**, }}$, $0.05^{\prime}$ ',

\section{St. Martin}

\begin{tabular}{|c|c|c|c|c|}
\hline Variable & Species & 1 Species 2 & W & $P$-value \\
\hline $\mathrm{N}$ & $\mathrm{Hw}$ & $\mathrm{Sf}$ & 87 & 0.0099 ** \\
\hline $\mathrm{N}$ & $\mathrm{Hw}$ & $\mathrm{Tt}$ & 62 & 0.7135 \\
\hline$N$ & $\mathrm{Tt}$ & Sf & 151 & $0.0027^{* *}$ \\
\hline C & $\mathrm{Hw}$ & Sf & 80 & 0.0446 * \\
\hline C & $\mathrm{Hw}$ & $\mathrm{Tt}$ & 76 & 0.1876 \\
\hline C & $\mathrm{Tt}$ & Sf & 137 & 0.0255 * \\
\hline$P$ & $\mathrm{Hw}$ & Sf & 10 & 0.1818 \\
\hline$P$ & $\mathrm{Hw}$ & $\mathrm{Tt}$ & 16 & 0.1176 \\
\hline P & $\mathrm{Tt}$ & Sf & 133 & 0.0041 * \\
\hline $\mathrm{CN}$ & $\mathrm{Hw}$ & Sf & 20 & 0.0199 * \\
\hline $\mathrm{CN}$ & $\mathrm{Hw}$ & $\mathrm{Tt}$ & 52 & 0.8154 \\
\hline $\mathrm{CN}$ & $\mathrm{Tt}$ & Sf & 29 & $0.0019^{* *}$ \\
\hline $\mathrm{CP}$ & $\mathrm{Hw}$ & Sf & 20 & 0.0314 * \\
\hline $\mathrm{CP}$ & $\mathrm{Hw}$ & $\mathrm{Tt}$ & 49 & 0.6642 \\
\hline $\mathrm{CP}$ & $\mathrm{Tt}$ & Sf & 23 & $0.0011^{*}$ \\
\hline NP & $\mathrm{Hw}$ & Sf & 49 & 0.9699 \\
\hline NP & $\mathrm{Hw}$ & $\mathrm{Tt}$ & 49 & 0.6642 \\
\hline NP & $\mathrm{Tt}$ & Sf & 90 & 0.7810 \\
\hline
\end{tabular}


Table 8. C, N, P content and their ratios \pm SD of calcareous green algae (ACG), other algae $(\mathrm{AO})$, H. stipulacea $(\mathrm{Hs})$, H. wrightii $(\mathrm{Hw})$, S. filiforme $(\mathrm{Sf})$, T. testudinum $(\mathrm{Tt})$ off St. Martin

\begin{tabular}{lcccccc}
\hline & ACG & AO & Hs & Hw & Sf & Tt \\
\hline $\mathrm{N}$ & $1.3 \pm 0.8$ & $2.2 \pm 1.3$ & $1.9 \pm 0.1$ & $1.9 \pm 0.4$ & $1.3 \pm 0.4$ & $1.8 \pm 0.2$ \\
$\mathrm{C}$ & $22.4 \pm 5.2$ & $31.7 \pm 8.6$ & $32.2 \pm 0.2$ & $37.6 \pm 1.1$ & $33.4 \pm 4.3$ & $36.6 \pm 2.0$ \\
$\mathrm{P}$ & $0.05 \pm 0.02$ & $0.06 \pm 0.03$ & $0.19 \pm 0.05$ & $0.16 \pm 0.04$ & $0.11 \pm 0.02$ & $0.15 \pm 0.01$ \\
$\mathrm{CN}$ & $19.1 \pm 5.2$ & $24.1 \pm 23.3$ & $16.6 \pm 0.5$ & $21.0 \pm 5.2$ & $27.0 \pm 6.0$ & $20.7 \pm 2.1$ \\
$\mathrm{CP}$ & $541.3 \pm 173.6$ & $715.3 \pm 573.5$ & $178.6 \pm 50.2$ & $242.1 \pm 62.0$ & $307.0 \pm 47.1$ & $249.8 \pm 19.3$ \\
$\mathrm{NP}$ & $29.8 \pm 11.5$ & $33.2 \pm 5.9$ & $10.7 \pm 2.7$ & $11.7 \pm 2.4$ & $11.7 \pm 2.7$ & $12.1 \pm 1.3$ \\
\hline
\end{tabular}
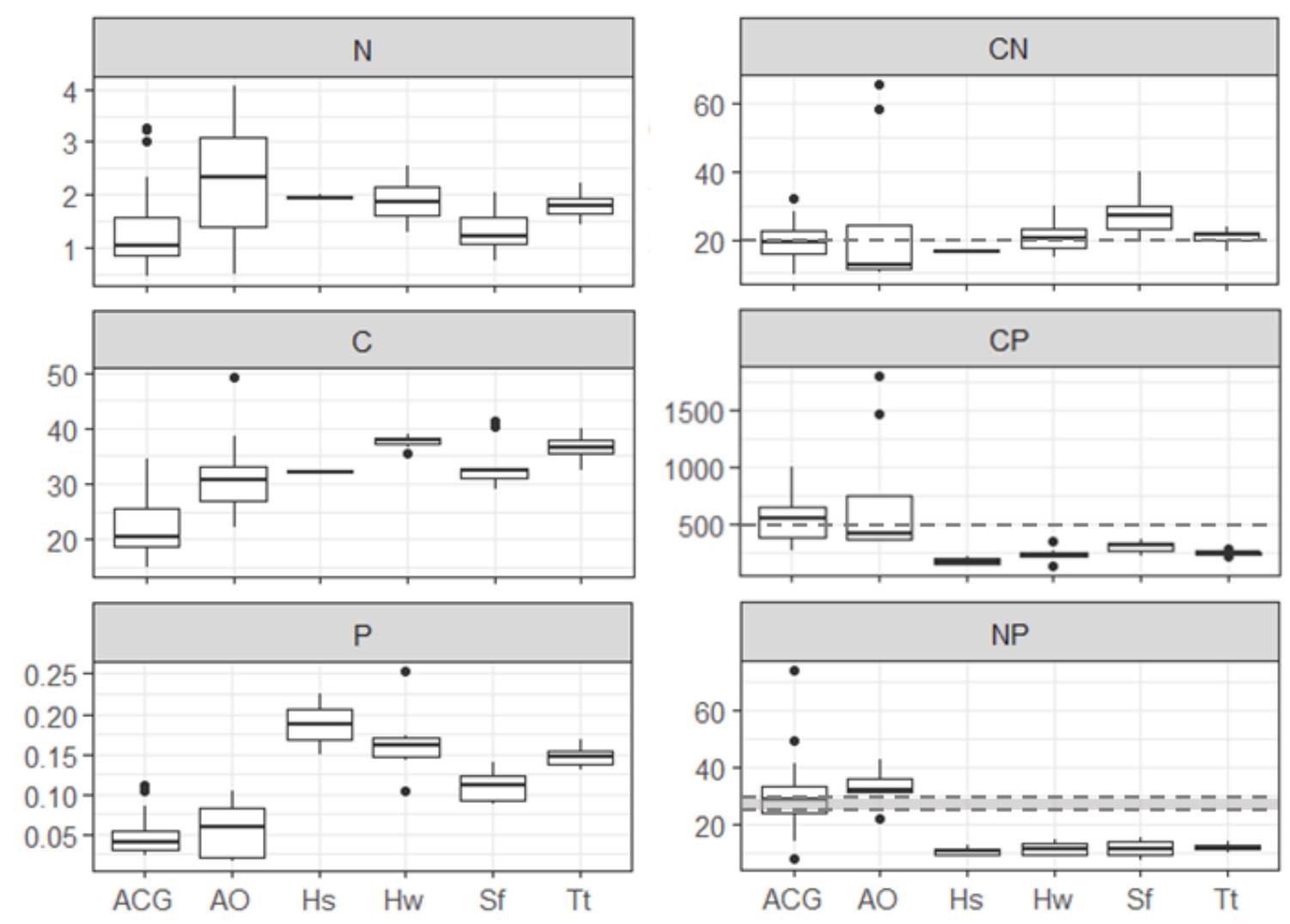

Species

Figure 9. Elemental composition off macrophytes of St. Martin; Left (top-bottom): C, N, and $\mathrm{P}$ content of calcareous green algae (ACG), other algae (AO), H. stipulacea $(\mathrm{Hs}), H$. wrightii (Hw), S. filiforme (Sf), T. testudinum (Tt); Right: Ratios of C:N, C:P, and N:P for each species; the dashed lines represent the seagrass Redfield ratio 


\section{Turtle abundance and distributions}

Green turtle sighting density (turtles/ha) did not vary significantly among sampling events within sites (Guadeloupe: $X^{2}=1.70$, df $=2, P=0.43$; Martinique: $X^{2}=$ 0.97, df $=2, P=0.462 ;$ St. Martin: $\left.X^{2}=0.001, \mathrm{df}=2, P=0.97\right)$. Overall, the mean density of turtles off Guadeloupe was more than three times that found off Martinique ( $W$ $=11032, P<0.0001)$ and St. Martin $(W=3752.5, P<0.0001)$ (Table 9, Figure 10). Turtle sighting density did not significantly differ between Martinique and St. Martin ( $W$ $=5059, P=0.61)$.

Table 9. Turtle sighting densities (Turtles/ha), total turtle sightings, transect length sum and total area surveyed for each site and sampling events.

\begin{tabular}{lcccc}
\hline & Turtles/ha & $\begin{array}{c}\text { Total turtle } \\
\text { sightings }\end{array}$ & $\begin{array}{c}\text { Total } \\
\text { transect } \\
\text { length } \mathbf{( k m )}\end{array}$ & $\begin{array}{c}\text { Total area } \\
\text { surveyed } \\
\text { (ha) }\end{array}$ \\
\hline Guadeloupe & $7.22 \pm 6.98$ & 761 & 59.93 & 89.90 \\
F16 & $6.79 \pm 5.31$ & 161 & 13.51 & 20.26 \\
S16 & $9.36 \pm 9.11$ & 133 & 8.21 & 12.31 \\
S17 & $5.56 \pm 5.43$ & 467 & 38.22 & 57.33 \\
Martinique & $2.26 \pm 3.75$ & 364 & 97.28 & 145.91 \\
F16 & $2.67 \pm 4.82$ & 116 & 32.69 & 49.04 \\
S16 & $2.16 \pm 3.05$ & 86 & 23.60 & 35.40 \\
S17 & $1.97 \pm 3.15$ & 162 & 40.98 & 61.47 \\
StMartin & $1.76 \pm 2.42$ & 171 & 42.71 & 64.06 \\
F16 & $1.75 \pm 2.27$ & 69 & 16.06 & 24.10 \\
S17 & $1.77 \pm 2.61$ & 102 & 26.64 & 39.97 \\
Grand Total & & 1296 & 199.92 & 299.88 \\
\hline
\end{tabular}



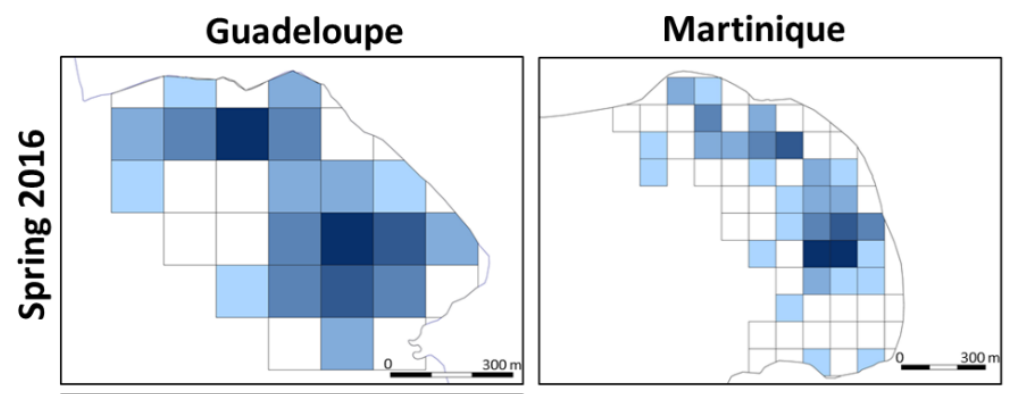

\section{Legend}

Sightings/ha

$\square 1.00-1.00$

$\square 1.00-2.00$

$\square 2.00-8.00$

- $8.00-14.00$
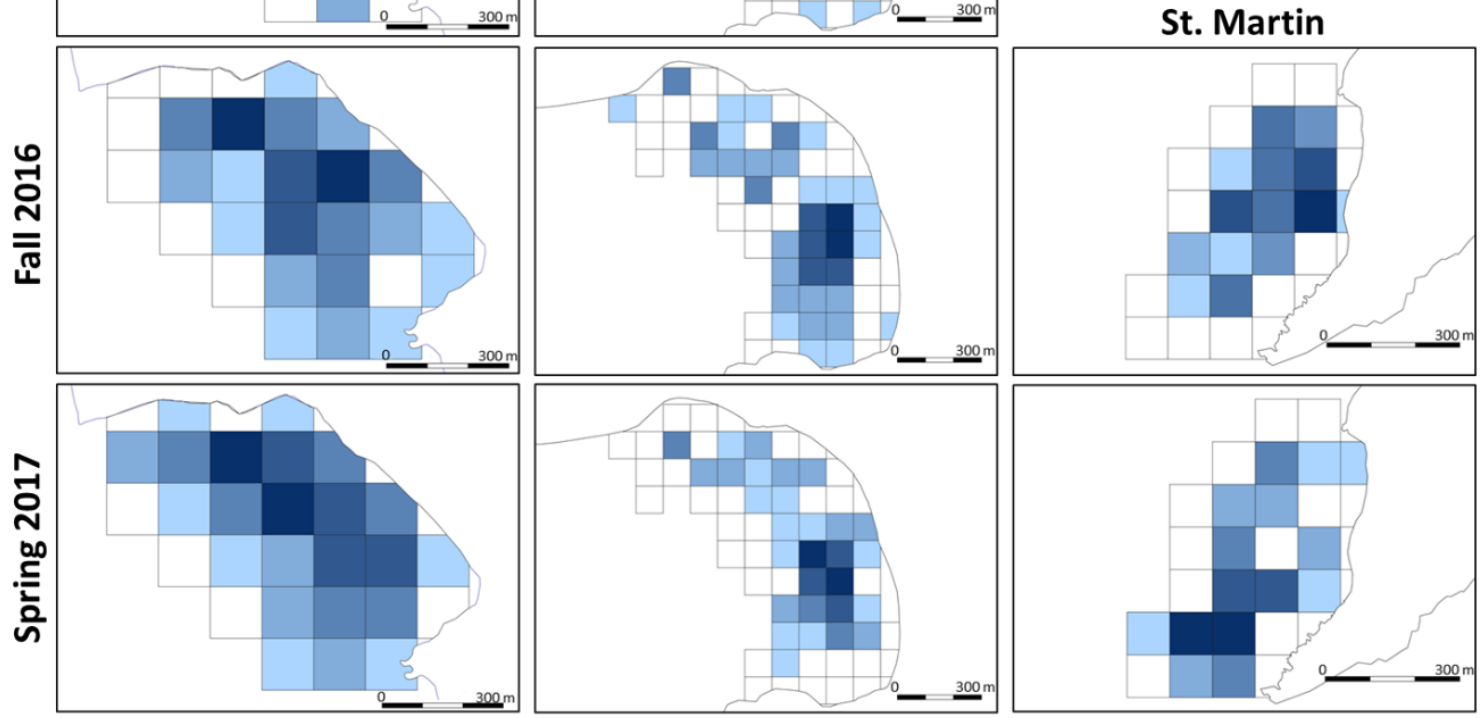

Figure 10. Mean turtle sightings per hectare for each sampling event and site

\section{Model selection}

\section{Guadeloupe}

Stepwise model selection of the generalized linear mixed effects model identified the best fit model to be:

$$
\text { Turtles } \sim S f+(1 \mid \operatorname{season})+\operatorname{offset}(\log (\text { Area }))
$$

where Turtles is the sightings count, $S f$ and represents the mean abundance of $S$. filiforme, season (sampling event) is set as the random effect and $\log ($ Area) is effort as the model offset. Predictor variables and interactions considered in the model selection 
are listed in Table 10, and models with interactions $(*)$ also test each independent variable. Accounting for differences between sampling events by setting sampling event as a random effect, turtle sighting abundance was positively correlated with $S$. filiforme abundance (Table 11, Figure 11).

Table10. Model selection table of turtle sightings in Guadeloupe with models ranked by AIC score from best fitting model to worst, where $\mathrm{K}$ is the number of parameters in the model, AICc is the information criterion for each model, $\delta \mathrm{AICc}$ is the difference between the AIC of respective model and the best fitting model, ModelLik is the relative likelihood of the model given the data, AICcWt are the Akaike weights and indicate the level of support for the model being the most parsimonious, LL is the log-likelihood, and Cum.Wt is the cumulative model weight (Mazerolle, 2017). * represents a test of the interaction and individual variables.

\begin{tabular}{lccccccc}
\hline Model & K & AlCc & Delta_AlCc ModelLik ACcWt & LL & Cum.Wt \\
\hline $\mathrm{Sf}$ & 3 & 380.42 & 0.00 & 1.00 & 0.51 & -186.92 & 0.51 \\
$\mathrm{Sf}{ }^{*} \mathrm{Hs}$ & 5 & 381.41 & 0.99 & 0.61 & 0.31 & -184.96 & 0.82 \\
$\mathrm{Tt}+\mathrm{Sf}+\mathrm{Hs}$ & 5 & 383.96 & 3.54 & 0.17 & 0.09 & -186.23 & 0.91 \\
$\mathrm{Tt}^{*} \mathrm{Sf}$ & 5 & 384.72 & 4.30 & 0.12 & 0.06 & -186.61 & 0.97 \\
$\mathrm{Tt}+\mathrm{Sf}+\mathrm{Hs}+$ Depth & 6 & 385.81 & 5.39 & 0.07 & 0.03 & -185.83 & 1.00 \\
$\sim$ & 2 & 433.93 & 53.51 & 0.00 & 0.00 & -214.83 & 1.00 \\
Depth & 3 & 433.93 & 53.51 & 0.00 & 0.00 & -213.68 & 1.00 \\
$\mathrm{Hs}$ & 3 & 434.58 & 54.16 & 0.00 & 0.00 & -214.00 & 1.00 \\
$\mathrm{Hs}{ }^{*} \mathrm{Tt}$ & 5 & 435.75 & 55.33 & 0.00 & 0.00 & -212.13 & 1.00 \\
$\mathrm{Tt}$ & 3 & 436.03 & 55.61 & 0.00 & 0.00 & -214.73 & 1.00 \\
\hline
\end{tabular}

Table 11. Results of generalized linear mixed effects best fit model for Guadeloupe; Significance

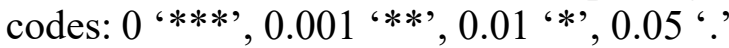

Fixed effects:

\begin{tabular}{|c|c|c|c|c|}
\hline & Estimate & Std. Error & $z$ value & $\operatorname{Pr}(>|z|)$ \\
\hline (Intercept) & -0.37 & 0.11 & -3.40 & $0.0007^{\star * *}$ \\
\hline Sf & 0.39 & 0.05 & 7.56 & $<0.0001^{* * *}$ \\
\hline
\end{tabular}



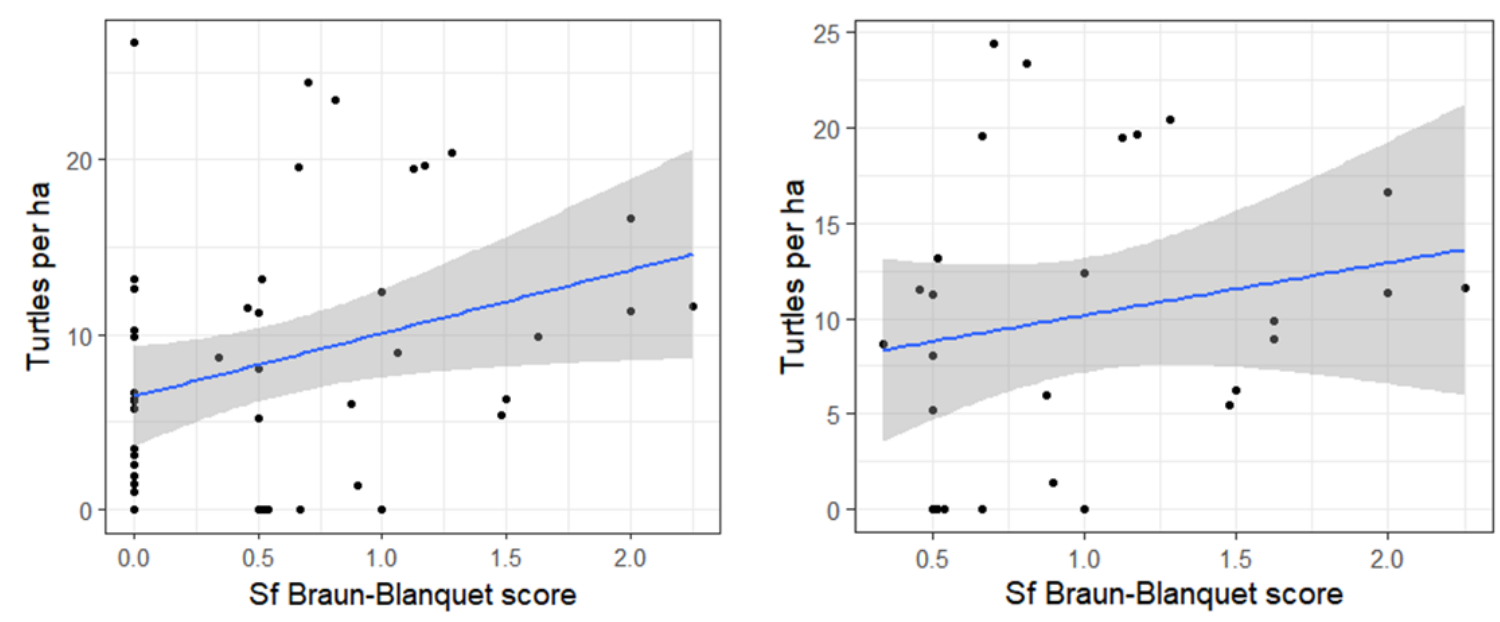

Figure 11. Relationship between turtle sighting densities (to account for effort) and Braun-Blanquet scores of S. filiforme off Guadeloupe. The shaded area represents the 95\% confidence interval; Left: including Braun-Blanquet scores equal to zero; Right: excluding Braun-Blanquet scores equal to zero

$\underline{\text { Martinique }}$

Stepwise model selection of the generalized linear mixed effects model identified the best fit model to be:

$$
\text { Turtles } \sim T t * S f+(1 \mid \operatorname{season})+\operatorname{off} \operatorname{set}(\log (\text { Area }))
$$

where Turtles is the sightings count $T t$ and $S f$ represent the mean abundance of native seagrasses T. testudinum and S. filiforme, respectively, * represents the interaction of variables, site and season (sampling event) are set as the random effects and $\log$ (Area) is effort as the model offset. Models considered in the model selection are listed in Table 12, and models with interactions $(*)$ also test each independent variable. Accounting for differences between sampling events by setting sampling event as a random effect, turtle abundance is affected by an interaction of T. testudinum and S. filiforme abundance 
(Table 13, Figure 12). Although there are increases in turtle sightings with increasing abundance of both species, some of the highest turtle densities occurred where $T$.

testudinum was abundant but S. filiforme was not (Figure 12).

Table 12. Model selection table of turtle sightings in Martinique with models ranked by AIC score from best fitting model to worst, where $\mathrm{K}$ is the number of parameters in the model, AICc is the information criterion for each model, $\delta \mathrm{AICc}$ is the difference between the AIC of respective model and the best fitting model, ModelLik is the relative likelihood of the model given the data, AICcWt are the Akaike weights and indicate the level of support for the model being the most parsimonious, LL is the log-likelihood, and Cum.Wt is the cumulative model weight (Mazerolle, 2017). * represents a test of the interaction and individual variables.

\begin{tabular}{lccccccc}
\hline Model & K & AlCc & Delta_AlCc ModelLik AlCcWt & LL & Cum.Wt \\
\hline $\mathrm{Tt}{ }^{*} \mathrm{Sf}$ & 5 & 310.68 & 0.00 & 1.00 & 1.00 & -149.82 & 1.00 \\
$\mathrm{Tt}+\mathrm{Sf}+\mathrm{Hs}+$ Depth & 6 & 331.98 & 21.30 & 0.00 & 0.00 & -159.24 & 1.00 \\
$\mathrm{Tt}$ & 3 & 333.35 & 22.67 & 0.00 & 0.00 & -163.47 & 1.00 \\
$\mathrm{Hs}{ }^{*} \mathrm{Tt}$ & 5 & 334.13 & 23.45 & 0.00 & 0.00 & -161.54 & 1.00 \\
$\mathrm{Tt}+\mathrm{Sf}+\mathrm{Hs}$ & 5 & 337.60 & 26.91 & 0.00 & 0.00 & -163.27 & 1.00 \\
$\mathrm{Depth}$ & 3 & 351.30 & 40.62 & 0.00 & 0.00 & -172.45 & 1.00 \\
$\mathrm{Sf}$ & 3 & 352.45 & 41.76 & 0.00 & 0.00 & -173.02 & 1.00 \\
$\mathrm{Sf}{ }^{*} \mathrm{Hs}$ & 5 & 356.35 & 45.67 & 0.00 & 0.00 & -172.65 & 1.00 \\
$\tilde{\mathrm{Hs}}$ & 2 & 358.87 & 48.19 & 0.00 & 0.00 & -177.34 & 1.00 \\
$\mathrm{H}$ & 3 & 359.05 & 48.37 & 0.00 & 0.00 & -176.32 & 1.00 \\
\hline
\end{tabular}

Table 13. Results of generalized linear mixed effects best fit model for Martinique; Significance codes: $0^{\text {‘***', }} 0.001^{\text {'**', }}, 0.01^{\text {'*', }}, 0.05^{\text {'.' }}$

Fixed effects:

\begin{tabular}{|c|c|c|c|c|}
\hline & Estimate & Std. Error & $z$ value & $\operatorname{Pr}(>|z|)$ \\
\hline (Intercept) & -1.79 & 0.11 & -16.22 & $<0.0001$ * \\
\hline $\mathrm{Tt}$ & & & & $1^{\text {** }}$ \\
\hline Sf & 0.7 & 0.1 & 4.37 & $<0.0001$ * \\
\hline Tt:Sf & -0.63 & 0.12 & -5.12 & $<0.0001$ \\
\hline
\end{tabular}



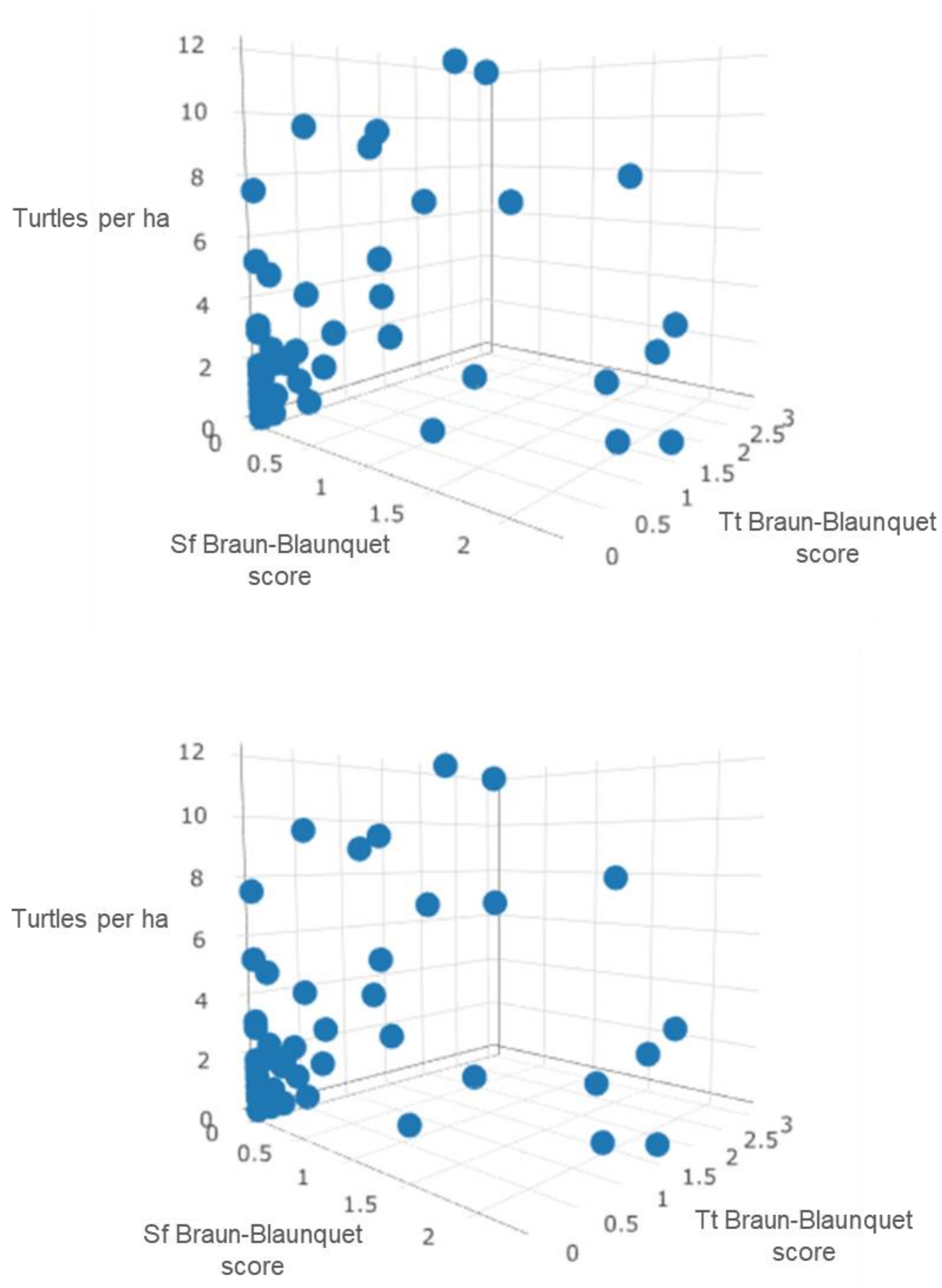

Figure 12. Relationships between turtle sighting densities (to account for effort) and the interaction of T. testudinum and S. filiforme Braun-Blanquet scores off Martinique of; Top panel includes sum of Braun-Blanquet scores equal to zero. Bottom panel excludes sum of Braun-Blanquet scores equal to zero 

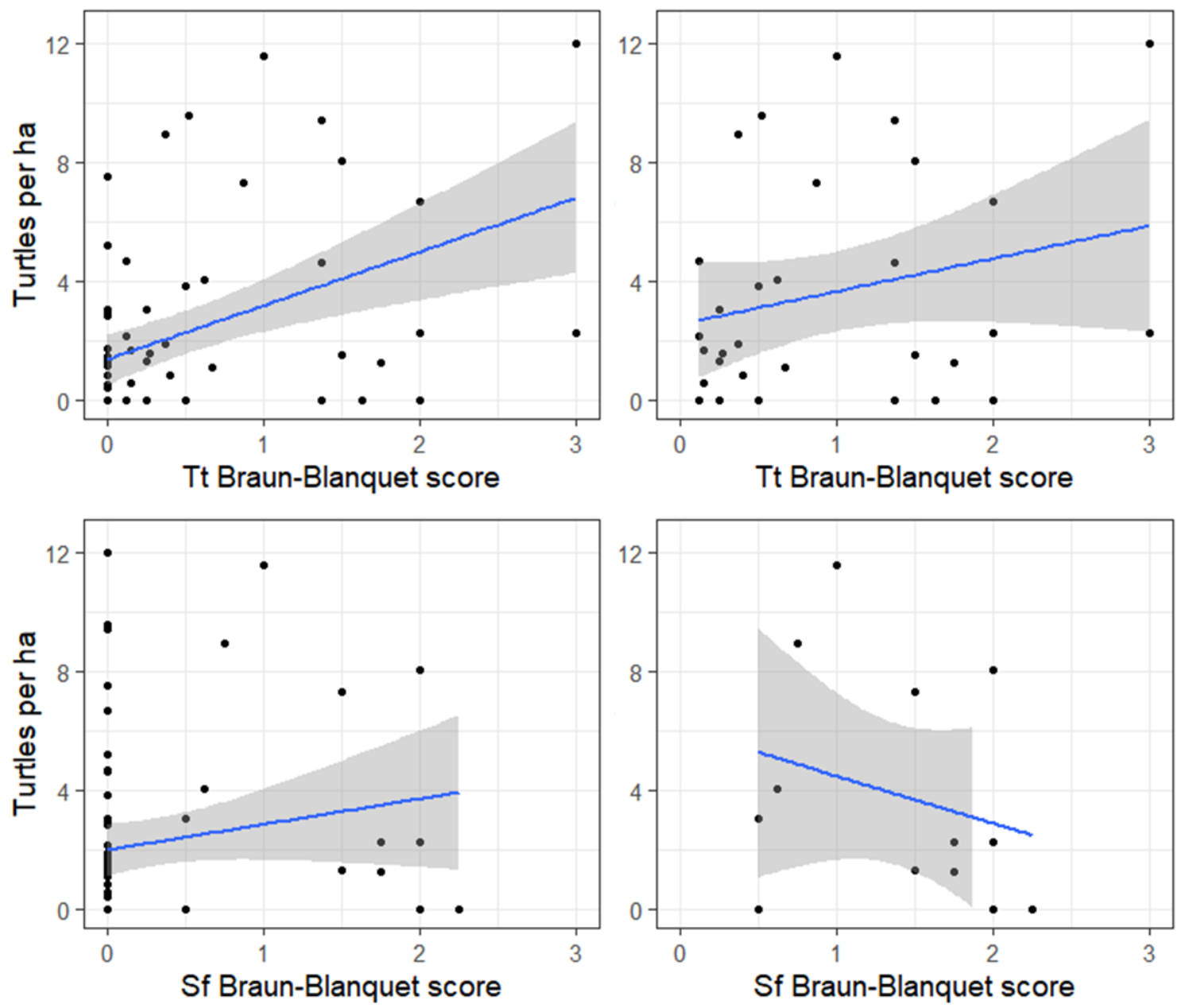

Figure 13. Relationships between turtle sighting densities (to account for effort) and Braun-Blanquet scores off Martinique of; Top: T. testudinum and Bottom: S. filiforme abundances and turtle sightings. The shaded area represents the $95 \%$ confidence interval. Left panels include sum of Braun-Blanquet scores equal to zero. Right panels exclude sum of Braun-Blanquet scores equal to zero. 


\section{$\underline{\text { St. Martin }}$}

Stepwise model selection of the generalized linear mixed effects model identified the best fit model to be:

$$
\text { Turtles } \sim T t * S f+S f * H w+(1 \mid \operatorname{season})+\operatorname{off} \operatorname{set}(\log (\text { Area }))
$$

where Turtles is the sightings count, $T t, S f$, and $H w$ represent the mean abundance of $T$. testudinum, $S$. filiforme, $H$. wrightii, respectively, season (sampling event) is set as the random effect and $\log ($ Area $)$ is effort as the model offset. Predictor variables and interactions considered in the model selection are listed in Table 14, and models with interactions $(*)$ also test each independent variable.

Table 14. Model selection table of turtle sightings in St. Martin with models ranked by AIC score from best fitting model to worst, where $\mathrm{K}$ is the number of parameters in the model, AICc is the information criterion for each model, $\delta \mathrm{AICc}$ is the difference between the AIC of respective model and the best fitting model, ModelLik is the relative likelihood of the model given the data, AICcWt are the Akaike weights and indicate the level of support for the model being the most parsimonious, LL is the log-likelihood, and Cum.Wt is the cumulative model weight (Mazerolle, 2017). * represents a test of the interaction and individual variables.

\begin{tabular}{lccccccc}
\hline Model & K & AlCc & Delta_AlCc & ModelLik & ACcWt & LL & Cum.Wt \\
\hline $\mathrm{Tt}^{*} \mathrm{Sf}+\mathrm{Sf}{ }^{*} \mathrm{Hw}$ & 7 & 243.16 & 0.00 & 1.00 & 0.97 & -112.71 & 0.97 \\
$\mathrm{Tt}{ }^{*} \mathrm{Sf}$ & 5 & 250.84 & 7.68 & 0.02 & 0.02 & -119.48 & 0.99 \\
$\mathrm{Sf}{ }^{*} \mathrm{Hw}$ & 5 & 255.29 & 12.13 & 0.00 & 0.00 & -121.71 & 1.00 \\
$\mathrm{Sf}$ & 3 & 255.90 & 12.74 & 0.00 & 0.00 & -124.60 & 1.00 \\
$\mathrm{Tt}$ & 3 & 257.54 & 14.38 & 0.00 & 0.00 & -125.42 & 1.00 \\
$\mathrm{Hw}$ & 3 & 258.39 & 15.23 & 0.00 & 0.00 & -125.84 & 1.00 \\
$\sim$ & 2 & 258.40 & 15.24 & 0.00 & 0.00 & -127.03 & 1.00 \\
$\mathrm{Tt}+\mathrm{Sf}+\mathrm{Hw}$ & 5 & 258.81 & 15.65 & 0.00 & 0.00 & -123.47 & 1.00 \\
$\mathrm{Depth}$ & 3 & 259.25 & 16.09 & 0.00 & 0.00 & -126.27 & 1.00 \\
$\mathrm{Hw}{ }^{*} \mathrm{Tt}$ & 5 & 259.62 & 16.46 & 0.00 & 0.00 & -123.87 & 1.00 \\
$\mathrm{Tt}+\mathrm{Sf}+\mathrm{Hw}+$ Depth & 6 & 261.44 & 18.28 & 0.00 & 0.00 & -123.37 & 1.00 \\
\hline
\end{tabular}


Accounting for differences between sampling events by setting sampling event as the random effect, turtle sighting abundance is positively correlated with $T$. testudinum and S. filiforme abundance, but negatively correlated with $H$. wrightii abundance. The interactions between $S$. filiforme with $T$. testudinum and with $H$. wrightii are also significant (Table 15, Figure13). Although there are increases in turtle sightings with increasing abundance of both $T$. testudinum and S. filiforme, some of the highest turtle densities occurred where S. filiforme and T. testudinum were found in similar proportions (Figure 13).

Table 15. Results of generalized linear mixed effects best fit model for St. Martin; Significance codes: 0 '***', $0.001^{\text {'**', }}, 0.01^{\text {'**', }} 0.05^{\text {'.' }}$

Fixed effects:

\begin{tabular}{|c|c|c|c|c|}
\hline & Estimate & Std. Error & z value & $\operatorname{Pr}(>|z|)$ \\
\hline (Intercept) & -2.26 & 0.29 & -7.93 & $<0.0001$ \\
\hline $\mathrm{Tt}$ & 0.95 & 0.22 & 4.24 & $<0.0001$ \\
\hline Sf & 0.76 & 0.22 & 3.44 & 0.0006 \\
\hline $\mathrm{Hw}$ & -1.23 & 0.46 & -2.69 & 0.0071 \\
\hline $\mathrm{Tt}: \mathrm{Sf}$ & -0.66 & 0.17 & -3.95 & 0.0001 \\
\hline Sf:Hw & 2.03 & 0.68 & 3.00 & 0.0027 \\
\hline
\end{tabular}



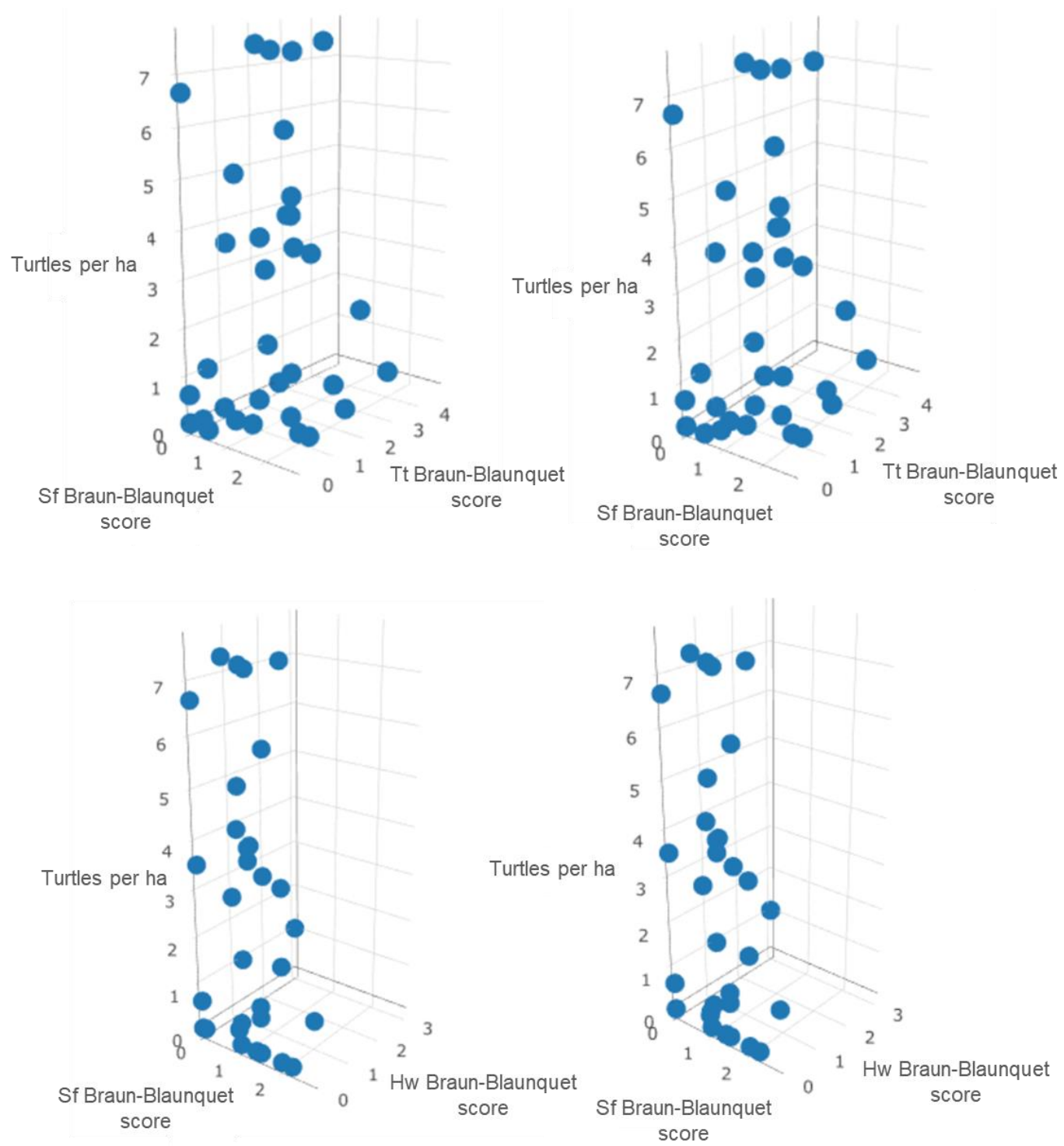

Figure 14. Relationships between turtle sighting densities (to account for effort) and Braun-Blanquet scores off St. Martin of; Top: the interaction of S. filiforme with $T$. testudinum and turtle sighting densities; Bottom: the interaction of S. filiforme with $H$. wrightii and turtle sighting densities. The shaded area represents the $95 \%$ confidence interval. Left panels include sum of Braun-Blanquet scores equal to zero. Right panels exclude sum of Braun-Blanquet scores equal to zero. 

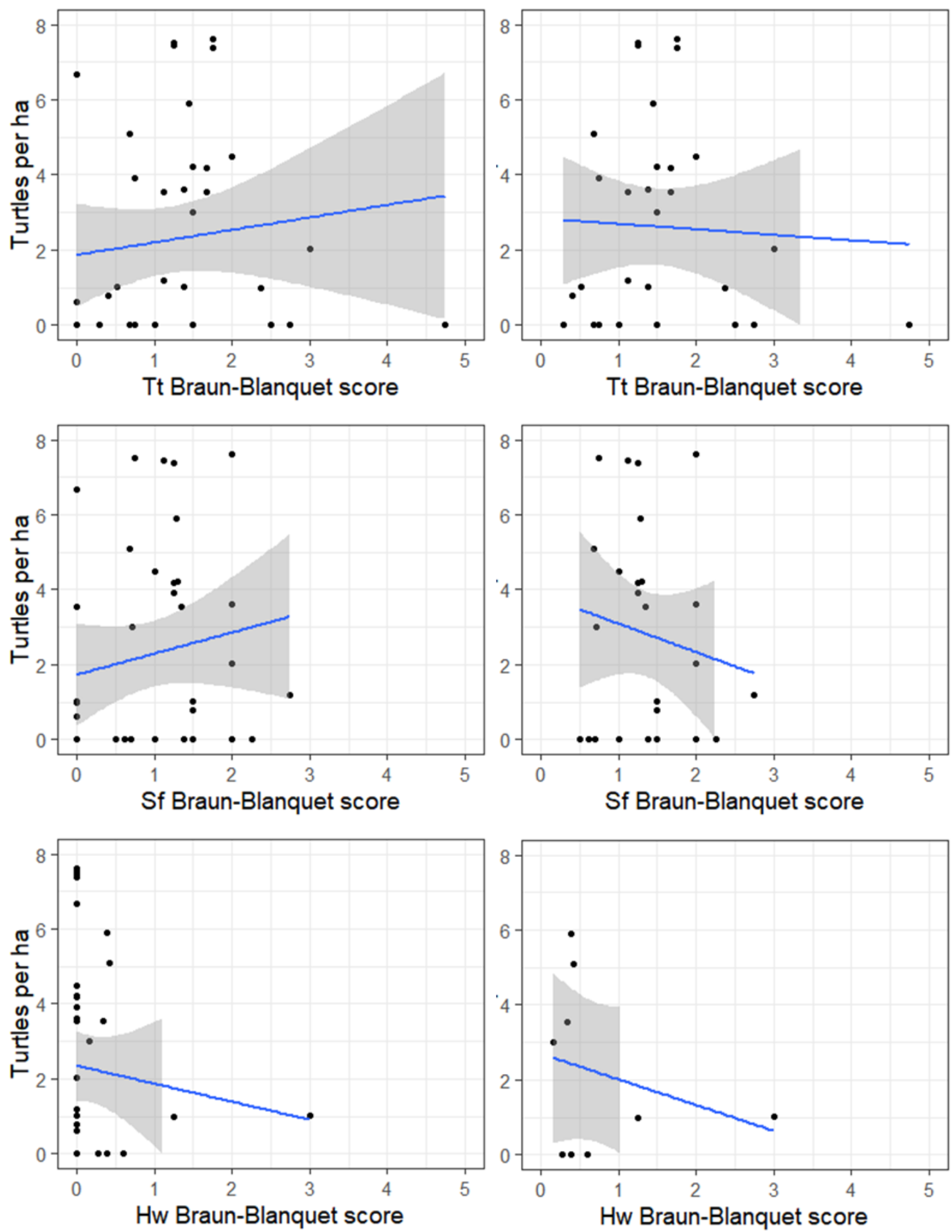

Figure 15. Relationships between turtle sighting densities (to account for effort) and Braun-Blanquet scores off St. Martin of; Top: T. testudinum, Middle: S. filiforme, and Bottom: $H$. wrightii Braun-Blanquet scores and turtle sighting densities. The shaded area represents the $95 \%$ confidence interval. Left panels include sum of Braun-Blanquet scores equal to zero. Right panels exclude sum of Braun-Blanquet scores equal to zero. 


\section{Resource selection}

A total of 301 turtle sightings across all sites were included in the selectivity analysis. At the population level, green turtles across all sites had a strong significant preference for the native seagrasses $S$. filiforme and T.testudinum over the invasive seagrass $H$. stipulacea (Khi2L $=174, d f=12, p<0.0001)$. Indeed, the mean selection ratios for S. filiforme, T.testudinum, and $H$. stipulacea were $1.39 \pm 0.05 \mathrm{SE}, 1.63 \pm 0.11$ $\mathrm{SE}$, and $0.45 \pm 0.04 \mathrm{SE}$, respectively (Figure 14). Turtles were observed in patches with an average of $1.8 \pm 0.52 \mathrm{SD}$ seagrass species at each sighting. However, green turtles showed a preference (visible foraging) for S. filiforme and T.testudinum, regardless of how many species they were foraging among. Turtles were occasionally observed foraging on the invasive $H$. stipulacea (see Chapter 5). 

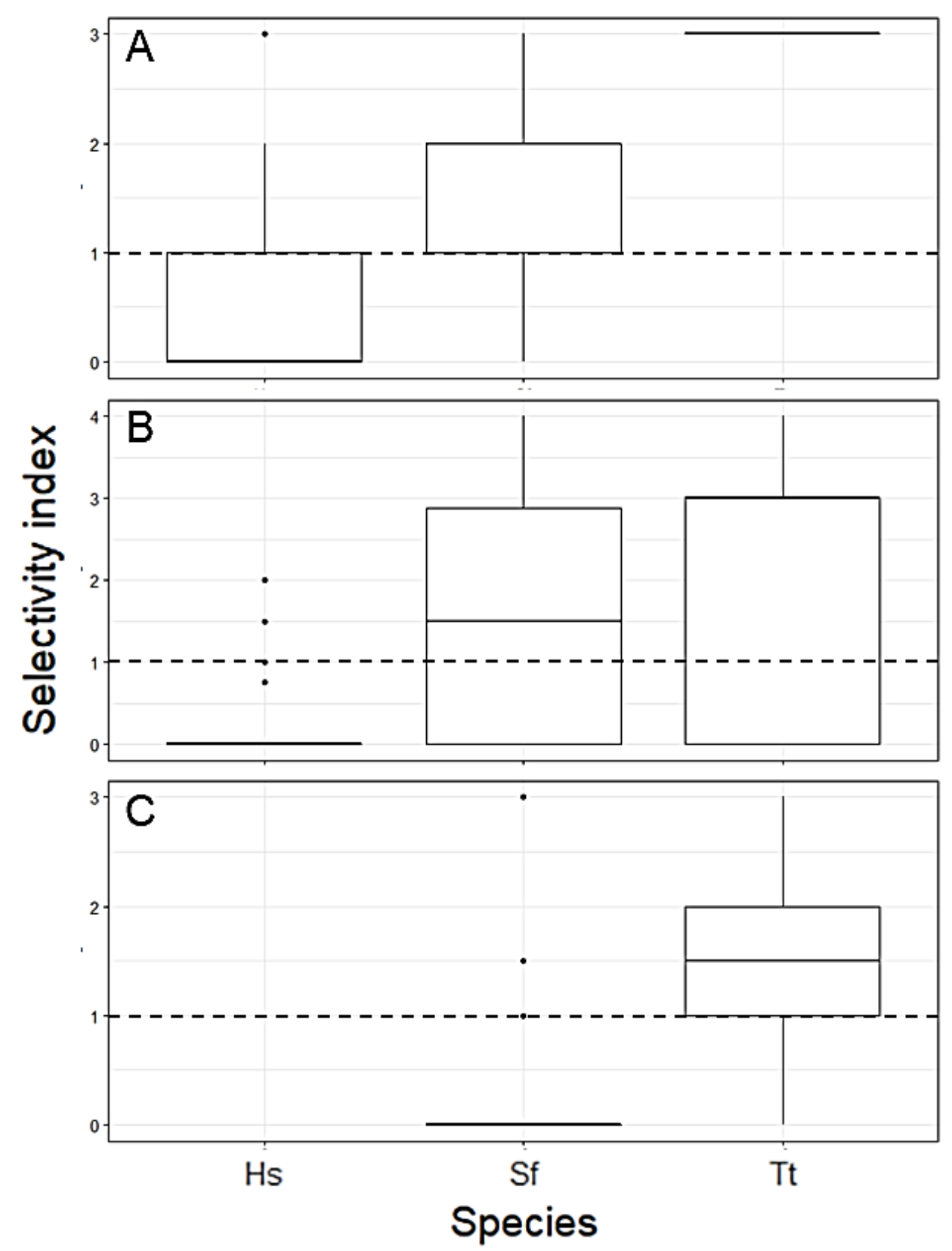

Figure 16. Selection ratios for T. testudinum (Tt), S. filiforme (Sf), and H. stipulacea (Hs) off A) Guadeloupe, B) Martinique, and C) St. Martin Each point represents the selection ratio at one turtle sighting; Values above 1.0 (dashed line) indicate positive selection, values below 1.0 indicate avoidance, and values near 1.0 indicate no apparent preference 


\section{Discussion}

Understanding how large grazers select habitats and resources in the face of invasion fronts is important for determining both how the invasion is likely to affect individual foragers and their populations as well as how grazer populations might facilitate or attenuate the invasion. Here, I found that green turtles - large marine herbivores - across multiple sites, used areas where invasive species were found less often than expected, and when foraging in areas where invasives occurred, chose native species over the invasive species. Selective foraging occurred even when the invasive seagrass appeared to have similar nutrient content to native species. These observations, taken together, suggest that the non-native seagrass invasion of the Caribbean is likely to, at least in the short term, negatively affect energy or nutrient budgets of green turtles, and green turtles may be facilitating the invasion via their selective grazing.

While forage availability can affect the distribution of large bodied herbivores (Power, 1992; Massé and Côté, 2009; Sheppard et al., 2010), some species of grazers are not limited by energy intake, and instead select foraging habitats and species on the basis the content of key nutrients (Murden and Risenhoover, 1993; Sheppard et al., 2010; Christianen et al., 2018). The elemental composition of seagrass leaves at each site provides clues to identify nutrients that may be particularly valuable to grazers. Low C:N and $\mathrm{C}: \mathrm{P}$ ratios of seagrass leaves suggested that all FWI study sites were nutrient rich (Atkinson and Smith, 1983), and green turtles in other parts of the Caribbean will select for high quality forage with ample amounts of N, P, and soluble sugars (Bjorndal, 1997; Christianen et al., 2018). 
Each study site provided a unique combination of forage abundance and quality for green turtles. In Guadeloupe, native S. filiforme was the most abundant native seagrass, it was found at most survey plots and at the highest density within the plots. The invasive $H$. stipulacea was also encountered in most surveys and was more abundant than S. filiforme within plots. The nutrient content of the invasive seagrass $H$. stipulacea and the native seagrass S. filiforme had comparable $\mathrm{C}$ and $\mathrm{N}$ content and only differed in $\mathrm{C}$ content.

In Martinique, H. stipulacea was found at more sampling points than native species, had the highest abundance scores of any seagrass species, and contained nutrients at mid-range values compared to native species. Of the native species, $T$. testudinum was found most often in surveys and had higher Braun-Blanquet scores than the other native seagrasses ( $S$. filiforme and $H$. wrightii). Patterns of nutrient composition among speicies were complex in this $\mathrm{N}$-limited bay. The invasive H. stipulacea had significantly greater $\mathrm{P}$ content than the native seagrasses., and greater $\mathrm{N}$ content than the native seagrass $S$. filiforme. The native $T$. testudinum, however, had the highest $\mathrm{N}$ content. In St. Martin T. testudinum was found most often but was found in similar covers at sites as S. filiforme. Both T. testudinum and S. filiforme were found more often and in greater abundance than $H$. wrightii. At St. Martin, H. stipulacea was rare. S. filiforme had significantly lower $\mathrm{N}$ and $\mathrm{C}$ content than both $H$. wrightii and T. testudinum and lower $\mathrm{P}$ content than T. testudinum.

Within and across sites, green turtle distributions were correlated with the abundance of native seagrasses $S$. filiforme and T. testudinum and not correlated with the 
abundance of the invasive seagrass $H$. stipulacea. One explanation for the pattern could be the relative quality of the available seagrasses. Results from Martinique and St. Martin were consistent with the hypothesis that turtles are driven by forage quality if turtles are selecting for $\mathrm{N}$ content. The abundances of turtles were most strongly associated with high abundances of the native $T$. testudinum, which had higher $\mathrm{N}$ content than the other seagrass species available. Turtles also showed positive selectivity for T. testudinum at the level of specific foraging locations. Green turtles in a study in Bonaire, Dutch Caribbean (Christianen et al., 2018) also showed a preference for consuming native $T$. testudinum which had higher soluble sugars, $\mathrm{N}$, and $\mathrm{P}$ content and a lower $\mathrm{C}: \mathrm{N}$ ratio than the invasive $H$. stipulacea.

While their results would suggest that turtles avoid invasive species because it is lower forage quality, results from Guadeloupe suggest that nutrient content alone may not drive turtle foraging decisions. Indeed, off Guadeloupe, nutrient contents of native and invasive seagrasses were similar. If nutrient content alone were driving foraging decisions, turtles should have selected habitats based on seagrass abundance regardless of species and foraged indiscriminately. Instead, turtles selected habitats depending on the abundance of the native seagrass $S$. filiforme. Furthermore, turtles showed a preference for this species even when foraging in patches with high abundances of invasive $H$. stipulacea (Chapter IV).

Another possible explanation for why turtles may be selecting habitats relative to the availability of native seagrasses and not the invasive $H$. stipulacea is that turtles may not yet recognize it as a potential food source. Sea turtles from the Cheloniidae family are 
believed to be use a combination of visual and chemical cues in forage selection, and green turtles have a greater ability to discriminate colors than pelagic fishes (Southwood et al., 2008). In the FWI, green turtles often appear to visually assess forage options by tilting their head to the side to get a close view of the benthos prior to beginning to forage (pers. obs.). However, it is unlikely that green turtles are not recognizing the invasive as a food source because, although most individuals avoided $H$. stipulacea, some individuals were observed foraging on the invasive in both Guadeloupe and Martinique (Figure 15) where it was more abundant than any native seagrass. Green turtles in Hawaii, have demonstrated diet plasticity, and incorporated invasive macrophytes as major components of their diets (Russell and Balazs, 2009, 2015). The studies in Hawaii lacked data on resource availability, but the authors suggested that the proportion of the diet of the green turtles made up of invasive species increased with time since invasion and with the relative abundance invasive species. The highly invasive seagrass $H$. stipulacea has been present in the Caribbean since 2002 (Willette and Ambrose, 2009), however, the results from this study and cafeteria experiments conducted 3-6 years after the first record of $H$. stipulacea in Bonaire (Debrot et al., 2012) suggest that green turtles selectively forage on native seagrasses even when the invasive is available equally or in greater abundance (Christianen et al., 2018). In Guadeloupe, the H. stipulacea invasion began six and seven years prior to this study (Willette et al., 2014), and green turtles may not yet have had to include greater proportions of the species in their diet in the manner Hawaiian turtles have.

Foraging habitat selection by large-bodied herbivores is likely context and species dependent (Redjadj et al., 2014). Ungulates in terrestrial systems make habitat use 
decisions on the basis of multiple factors. Elk (Cervus elaphus) in northeastern Nevada, USA selected habitat based on forage availability and distance to water. In a study of a high-density white-tailed deer population, fine-scale habitat selection was mainly determined by forage abundance (Massé and Côté, 2009), but habitat selection was not significantly dependent on the biomass of preferred plant species. The high-arctic Avalbard reindeer (Rangifer tarandus platyrhinchus) provide perhaps the best parallel between green turtles in the FWI and a large-bodied herbivore in terrestrial habitats. They are non-gregarious, non-territorial, free from predation risk, and have no inter-specific competition (Hansen et al., 2009). Reindeer in habitats with low forage availability and productivity selected home ranges and resource patches based on productivity, however, reindeer in habitats with relatively high forage availability and productivity selected habitats based on conditions supportive of high forage quality over forage biomass. White-tailed deer (Odocoileus virginianus) and Angora goats (Capri hircus) began feeding selectively for high-quality natural forage options when they were also provided with a high-quality diet supplement (Murden and Risenhoover, 1993). Marine herbivores also use multiple factors in their decision making over habitat utilization. Dugong (Dugong dugong) selected seagrass patches for high nitrogen concentrations, however, when habitat space was limited by low tides, their habitat use shifted to patches with high seagrass biomass (Sheppard et al., 2010). Therefore, it is likely that green turtles base their habitat selection on multiple factors, and additional studies of forage biomass and productivity are warranted.

Selective grazing of green turtles may be facilitating the H. stipulacea invasion in the Caribbean and may be leading to a loss of macrophyte diversity as the invasive 
spreads (Chapter V; Christianen et al., 2018). At one site, Guadeloupe, both mean seagrass species richness and mean S. filiforme decreased from Spring 2016 to Spring 2017. These results need to be interpreted with caution because sample sizes and point locations differed across sampling events, but if this is in fact the trend, it is consistent with surveys in other locations in the Caribbean (e.g., Willette et al., 2012; Scheibling et al., 2018). Previous mapping of the benthos in Martinique between 2006 and 2010 surveys revealed new settlement of $H$. stipulacea in $58.2 \%$ of the surveyed area, whereas new settlements of S. filiforme were found in only $7.46 \%$ of sites (Legrand et al., 2012). There are important long-term implications for the ecosystem if $H$. stipulacea is outcompeting native species. Organisms that depend on native seagrasses for food or for their physical structure, and who cannot adapt to the shift in the seagrass community will find their available habitat decreasing. However, the spread of $H$. stipulacea may positively affect fish communities by supporting more faunal species (richness) and large fish (length in cm) (Willette and Ambrose 2012; Rogers, Willette, and Miller 2014). Amphipod and crustacean abundances were also found to be significantly greater in meadows of the invasive $H$. stipulacea than in the native $S$. filiforme, which may be contributing factors to increases in fish metrics. So far, however, the invasion is most likely detrimental or, at best, inconsequential for green turtles.

Bjorndal and Jackson (2003) used total area covered and productivity ranges of $T$. testudinum in the Caribbean a proxy for food available to turtles to use in population reconstructions, however, Heithaus et al. (2008) argued that herbivore populations are also limited by direct predation and predation risk. Herbivores are faced with a food-risk tradeoff may avoid especially risky areas if the less risky areas can support the individual 
and population energy requirements. In a relatively pristine marine ecosystem of Shark Bay, Australia, dugongs change their habitat use and foraging behavior depending on seasonal patterns in risk from tiger shark encounters (Wirsing, Heithaus and Dill, 2007), and healthy green turtles preferentially foraged in seagrass meadow edge habitats where they are less likely to encounter predators (Heithaus et al., 2007). Predators can constrain foraging site selection, but other factors could constrain their habitat such as human activity (Frid and Dill, 2002) and invasive forage species, and potentially further restrict carrying capacity (K) for the Caribbean. If green turtles continue to avoid $H$. stipulacea, their foraging habitat range will be reduced by invasion and potentially equate to less energy availability, lower intake rates, slower growth, or lower K. Moose (Alces alces) habitat selection in Norway at the landscape scale selected for high availability of forage, and within those habitats selected for higher quality forage most of the year, but when resources were depleted in the winter season moose site fidelity decreased and they selected lower quality forage (van Beest et al., 2010). Should green turtles, like the moose, adapt to the depletion of their preferred resource (native seagrasses), they may exhibit decreased foraging site fidelity, costing them additional energy travelling among sites for forage.

In the FWI, I found that turtles may not avoid patches with invasive seagrass if native seagrasses are present, however, within the patch turtles are selecting for native seagrasses and avoiding the invasive and macroalgae (this chapter, Chapter IV). The results support the hypothesis that, like other large bodied herbivores, green turtles select foraging habitats on the basis of preferred forage abundance and select for high quality forage (where available) within patches. My analysis of green turtle foraging habitat and 
resource selection in the FWI elucidates the importance of multi-level, multi-scale ecosystem management. The observation of grazers continuing to use habitat invaded by a non-native plant species is not sufficient to estimate its affect (or lack thereof) on the grazer.

Invasive plants are particularly successful when they benefit from a lack of enemies (Enemy Release Hypothesis; ERH; Cogni 2010; Keane and Crawley 2002), and are potentially more successful when the lack of enemies is coupled with a high-resource (nutrients) environment (Resource-Enemy Release Hypothesis; R-ERH; Blumenthal, 2005, 2006). The comparison of seagrass nutrient content to established seagrass Redfield ratios revealed that the sites in Guadeloupe, Martinique, and St. Martin are nutrient rich habitats, and a lack of interest by foraging green turtles may, at least in part, explain the successful invasion of $H$. stipulacea in the region.

\section{Acknowledgments}

This work was funded by the TOTAL Foundation. The bulk of the field assistance was provided by Jeremy Kiszka, Vincent Quiquempois, Manon Niviere, Lisa Allioud, Jeffrey Bernus, Phil Matich, and Caitlyn Webster. Permits and assistance were provided by Office National de la Chasse et de la Faune Sauvage (French Wildlife Service), Reseau Tortue Guadeloupe (Sea Turtle Network - Guadeloupe), DEAL Guadeloupe, and the National Park of Guadeloupe. Thanks to DEAL Martinique for delivering research permits and for their assistance in the field and the Reserve Naturelle de Saint Martin for their support and involvement in field activities, particularly Julien Chalifour. 


\section{References}

Atkinson, A. M. J. and Smith, S. V (1983). C : N : P ratios of benthic marine plants, Limnology and Oceanography, 28(3), pp. 568-574.

van Beest, F. M. et al. (2010). Forage quantity, quality and depletion as scale dependent mechanisms driving habitat selection of a large browsing herbivore, Journal of Animal Ecology, 79(4), pp. 910-922. doi: 10.1111/j.1365-2656.2010.01701.x.

Bjorndal, K. A. (1980). Nutrition and grazing behavior of the green turtle Chelonia mydas, Marine Biology, 56(2), pp. 147-154. doi: 10.1007/BF00397131.

Bjorndal, K. A. (1997). Foraging ecology and nutrition of sea turtles', in The biology of sea turtles 1, pp. 199-231.

Bjorndal, K. and Jackson, J. (2002). Roles of Sea Turtles in Marine Ecosystems, in Lutz, P. L., Musick, J. A., and Wyneken, J. (eds) The Biology of Sea Turtles, Volume II. Boca Raton: CRC Press, pp. 259-273. doi: doi:10.1201/9781420040807.ch10.

Blumenthal, D. M. (2005). Interrelated causes of plant invasion, Science, 310(5746), pp. 243-244. doi: 10.1126/science.1114851.

Blumenthal, D. M. (2006). Interactions between resource availability and enemy release in plant invasion, Ecology Letters, 9(7), pp. 887-895. doi: 10.1111/j.14610248.2006.00934.x.

Brooks, M. L. et al. (2004). Effects of invasive alien plants on fire regimes, AIBS Bulletin, 54(7), 677-688.

Brooks, M. L. and Esque, T. C. (2002). Alien plants and fire in desert tortoise (Gopherus agassizii) habitat of the Mojave and Colorado deserts, Chelonian Conservation and Biology, 4, pp. 330-340.

Burkholder, D. A. et al. (2011). Diversity in trophic interactions of green sea turtles Chelonia mydas on a relatively pristine coastal foraging ground, Marine Ecology Progress Series, 439, pp. 277-293. doi: 10.3354/meps09313.

Calenge, C. (2006). The package adehabitat for the R software: a tool for the analysis of space and habitat use by animals. Ecological Modelling, 197, 516-519.

Christianen, M. J. A. et al. (2018). Megaherbivores may impact expansion of invasive seagrass in the Caribbean, Journal of Ecology, pp. 0-1. doi: 10.1111/13652745.13021 .

Cogni, R. (2010). Resistance to Plant Invasion? A Native Specialist Herbivore Shows Preference for and Higher Fitness on an Introduced Host, Biotropica, 42(2), pp. 188-193. doi: 10.1111/j.1744-7429.2009.00570.x.

Debrot, A. O. et al. (2012). Basline surveys of Lac Bay benthis and fish communities, Bonaire, IMARES Wageningen UR, (No. C129/12), pp. 1-52. IMARES. 
Fourqurean, J. W. et al. (2001). Spatial and temporal pattern in seagrass community composition and productivity in south Florida, Marine Biology, 138(2), pp. 341354. doi: 10.1007/s002270000448.

Frid, A. and Dill, L. (2002). Human-caused disturbance stimuli as a form of predation risk', Conservation Ecology, 6(1), p. 16. doi: 10.2307/26271862.

Fuentes, M. M. P. B., Lawler, I. R. and Gyuris, E. (2006). Dietary preferences of juvenile green turtles (Chelonia mydas) on a tropical reef flat, Wildlife Research, 33, pp. 671-678. doi: 10.1071/WR05081

Grosholz, E. (2010). Avoidance by grazers facilitates spread of an invasive hybrid plant, Ecology Letters, 13(2), pp. 145-153. doi: 10.1111/j.1461-0248.2009.01409.x.

Hansen, B. B. et al. (2009). Functional response in habitat selection and the tradeoffs between foraging niche components in a large herbivore, Oikos, 118(6), pp. 859872. doi: 10.1111/j.1600-0706.2009.17098.x.

Hays, C. G. (2005). Effect of nutrient availability, grazer assemblage and seagrass source population on the interaction between Thalassia testudinum (turtle grass) and its algal epiphytes, Journal of Experimental Marine Biology and Ecology, 314(1), pp. 53-68. doi: 10.1016/j.jembe.2004.08.017.

Heithaus, M. R. et al. (2007). State-dependent risk-taking by green sea turtles mediates top-down effects of tiger shark intimidation in a marine ecosystem, The Journal of animal ecology, 76(5), pp. 837-44. doi: 10.1111/j.1365-2656.2007.01260.x.

Heithaus, M. R. et al. (2008.). A review of lethal and non-lethal effects of predators on adult marine turtles, Journal of Experimental Marine Biology and Ecology, 356(12), pp. 43-51. doi: 10.1016/j.jembe.2007.12.013.

Johnson, D. H. (1980). The comparison of usage and availability measurements for evaluating resource preference, Ecology, 61(1), pp. 65-71.

Katsanevakis S. et al. (2014). Impacts of invasive alien marine species on ecosystem services and biodiversity: a pan-European review, NEOBIOTA 2014 - 8th International Conference on Biological Invasions, 9(4), pp. 116-117. doi: 10.3391/ai.2014.9.4.01.

Keane, R. and Crawley, M. (2002). Exotic plant invasions and the enemy release hypothesis, Trends in Ecology \& Evolution, 17(4), pp. 164-170. doi: https://doi.org/10.1016/S0169-5347(02)02499-0.

Kelkar, N. et al. (2013). Greener pastures? High-density feeding aggregations of green turtles precipitate species shifts in seagrass meadows, Journal of Ecology. p. n/an/a. doi: 10.1111/1365-2745.12122.

Kelkar, N. et al. (2013). Greener pastures? High-density feeding aggregations of green turtles precipitate species shifts in seagrass meadows. Journal of Ecology, 101(5), 1158-1168. https://doi.org/10.1111/1365-2745.12122 
Kleynhans, E. J. et al. (2011). Resource partitioning along multiple niche dimensions in differently sized African savanna grazers, Oikos, 120(4), pp. 591-600. doi: 10.1111/j.1600-0706.2010.18712.x.

Lal, A. et al. (2010). Implications of conserving an ecosystem modifier: Increasing green turtle (Chelonia mydas) densities substantially alters seagrass meadows, Biological Conservation. 143(11), pp. 2730-2738. doi: 10.1016/j.biocon.2010.07.020.

Legrand, H. et al. (2012). Mapping marine benthic habitats in Martinique (French West Indies), Caribbean Journal of Science, 46(2), pp. 267-282.

Manly B. F. J. et al. (2002). Resource selection by animals: statistical design and analysis for field studies, 2nd edn. Springer Science \& Business Media. Kluwer, Dordrecht

Massé, A. and Côté, S. D. (2009). Habitat selection of a large herbivore at high density and without predation: Trade-off between Forage and Cover?, Journal of Mammalogy, 90(4), pp. 961-970. doi: 10.1644/08-MAMM-A-148.1.

Murden, S. B. and Risenhoover, K. L. (1993). Effects of habitat enrichment on patterns of diet selection, Ecological Applications, 3(3), pp. 497-505.

Posey, M. H. (1988). Community changes associated with the spread of an introduced seagrass, Zostera japonica, Ecology, 69(4), pp. 974-983.

Power, M. (1992). Top-down and bottom-up forces in food webs: do plants have primacy, Ecology, 73(3), pp. 733-746. Available at: http://www.esajournals.org/doi/abs/10.2307/1940153 (Accessed: 20 May 2014).

Power, M. E. (1983). Grazing responses of tropical freshwater fishes to different scales of variation in their food, Environmental Biology of Fishes, 9(2), pp. 103-115. doi: $10.1007 / \mathrm{bf00690856.}$

Pringle, R. M. (2018). Ecology: Megaherbivores Homogenize the Landscape of Fear, Current Biology. 28(15), pp. R835-R837. doi: 10.1016/j.cub.2018.06.050.

QGIS Development Team (2018). QGIS Geographic Information System. Open Source Geospatial Foundation Project. http://qgis.osgeo.org

R Core Team (2016). R: A language and environment for statistical computing. R Foundation for Statistical Computing, Vienna, Austria. https://www.R-project.org/.

Redjadj, C. et al. (2014). Intra- and interspecific differences in diet quality and composition in a large herbivore community, PLOS ONE, 9(2). doi:

10.1371/journal.pone.0084756.

Rodriguez, L. F. (2006.). Can invasive species facilitate native species? Evidence of how, when, and why these impacts occur, Biological Invasions, 8(4), pp. 927-939. doi: 10.1007/s10530-005-5103-3. 
Rogers, C. S., Willette, D. A. and Miller, J. (2014). Rapidly spreading seagrass invades the Caribbean with unknown ecological consequences, Frontiers in Ecology and the Environment, 12(10), pp. 546-547. doi: 10.1890/14.WB.015.

Roos, D. et al. (2005). Aerial and snorkelling census techniques for estimating green turtle abundance on foraging areas: A pilot study in Mayotte Island (Indian Ocean), Aquatic Living Resources, 198, pp. 193-198. doi: 10.1051/alr.

Ruiz, H. and Ballantine, D. L. (2004). Occurrence of the seagrass Halophila stipulacea in the tropical west Atlantic, Bulletin of Marine Science, 75(1), pp. 131-135. http://www.ingentaconnect.com/content/umrsmas/bullmar/2004/00000075/0000000 1/art00011 (Accessed: 23 October 2014).

Ruiz, H., Ballantine, D. L. and Sabater, J. (2017). Continued spread of the seagrass Halophila stipulacea in the Caribbean: Documentation in Puerto Rico and the British Virgin Islands, Gulf and Caribbean Research, 28(1), pp. SC5-SC7. doi: 10.18785/gcr.2801.05.

Russell, D. J. et al. (2003). Discovery of the sea grass Halophila decipiens (Hydrocharitaceae) in the diet of the Hawaiian green turtle, Chelonia mydas, Pacific Science, 57(4), pp. 393-397. doi: 10.1353/psc.2003.0034.

Russell, D. J. and Balazs, G. H. (2009). Dietary Shifts by Green Turtles (Chelonia mydas) in the Kāne'ohe Bay Region of the Hawaiian Islands: A 28-Year Study, Pacific Science, 63(2), pp. 181-192. doi: 10.2984/049.063.0202.

Russell, D. J. and Balazs, G. H. (2015). Increased use of non-native algae species in the diet of the Green Turtle (Chelonia mydas) in a primary pasture ecosystem in Hawaii, Aquatic Ecosystem Health and Management, 18(3), pp. 342-346. doi: 10.1080/14634988.2015.1027140.

Scheibling, R. E., Patriquin, D. G., \& Filbee-Dexter, K. (2018). Distribution and abundance of the invasive seagrass Halophila stipulacea and associated benthic macrofauna in Carriacou, Grenadines, Eastern Caribbean. Aquatic Botany, 144, 18. https://doi.org/10.1016/j.aquabot.2017.10.003

Sheppard, J. K. et al. (2010). Dugong habitat use in relation to seagrass nutrients, tides, and diel cycles, Marine Mammal Science, 26(4), pp. 855-879. doi: 10.1111/j.17487692.2010.00374.x.

Solórzano, L. and Sharp, J. H. (1980). Determination of total dissolved phosphorus and particulate phosphorus in natural waters, Limnology and Oceanography, 25(4), pp. 754-758.

Southwood, A. et al. (2008). Sound, chemical, and light detection in sea turtles and pelagic fishes: Sensory-based approaches to bycatch reduction in longline fisheries. Endangered Species Research, 5(2-3), 225-238. https://doi.org/10.3354/esr00097 
Streftaris, N. and Zenetos, A. (2006). Alien marine species in the Mediterranean - the 100 "worst invasives" and their impact, Mediterranean Marine Science, 7(1), pp. 87118. doi: $10.12681 / \mathrm{mms} .180$.

Verdolin, J. L. (2006). Meta-analysis of foraging and predation risk trade-offs in terrestrial systems, Behavioral Ecology and Sociobiology, 60(4), pp. 457-464. doi: 10.1007/s00265-006-0172-6.

Wabnitz, C. et al. (2010). Ecosystem structure and processes at Kaloko Honokohau, focusing on the role of herbivores, including the green sea turtle Chelonia mydas, in reef resilience, Marine Ecology Progress Series, 420, pp. 27-44. doi: 10.3354/meps08846.

Waldram, M. S., Bond, W. J. and Stock, W. D. (2008). Ecological engineering by a mega-grazer: White Rhino impacts on a south African savanna, Ecosystems, 11(1), pp. 101-112. doi: 10.1007/s10021-007-9109-9.

Willette, D. A., and Ambrose, R. F. (2012). Effects of the invasive seagrass Halophila stipulacea on the native seagrass, Syringodium filiforme, and associated fish and epibiota communities in the Eastern Caribbean. Aquatic Botany, 103, 74-82. https://doi.org/10.1016/j.aquabot.2012.06.007

Willette, D. A. et al. (2014). Continued expansion of the trans-Atlantic invasive marine angiosperm Halophila stipulacea in the Eastern Caribbean, Aquatic Botany, 112, pp. 98-102. doi: 10.1016/j.aquabot.2013.10.001.

Willette, D. a. and Ambrose, R. F. (2009). The distribution and expansion of the invasive seagrass Halophila stipulacea in Dominica, West Indies, with a preliminary report from St. Lucia, Aquatic Botany, 91(3), pp. 137-142. doi:

10.1016/j.aquabot.2009.04.001.

Willette, D. A. and Ambrose, R. F. (2012). Effects of the invasive seagrass Halophila stipulacea on the native seagrass, Syringodium filiforme, and associated fish and epibiota communities in the Eastern Caribbean, Aquatic Botany. Elsevier B.V., 103, pp. 74-82. doi: 10.1016/j.aquabot.2012.06.007.

Wirsing, A. J., Heithaus, M. R. and Dill, L. M. (2007). Fear factor: Do dugongs (Dugong dugon) trade food for safety from tiger sharks (Galeocerdo cuvier)?, Oecologia, 153(4), pp. 1031-1040. doi: 10.1007/s00442-007-0802-3. 


\section{CHAPTER V}

GREEN TURTLE FORAGING PREFERENCES FOR NATIVE SEAGRASSES COULD FACILITATE THE HALOPHILA STIPULACEA INVASION OF THE CARIBBEAN SEA: A TEST OF THE ENEMY RELEASE HYPOTHESIS 


\begin{abstract}
Invasions may succeed because they are not controlled by natural enemies in a novel environment (Enemy Release Hypothesis; ERH). If local consumers preferentially feed on native species, they can facilitate invasions, while preferential or even non-selective feeding on an invader could minimize its impact. Halophila stipulacea, a seagrass native to the western Indian Ocean, has spread to the Mediterranean and Caribbean. Yet, little is known about the ecological consequences of the invasion or how local species might influence its persistence and spread. As locally abundant, large-bodied grazers, green turtles (Chelonia mydas) could either facilitate or attenuate the H. stipulacea invasion depending on their foraging patterns in the presence of native and invasive seagrasses. We tested a priori predictions about green turtle foraging behavior in the presence of $H$. stipulacea and native seagrasses off the west coast of Guadeloupe to investigate the ERH. Using turtle focal follows $(\mathrm{n}=70)$, we assessed individual and population level foraging preferences. Turtles foraged across a wide range of microhabitats including monospecific meadows and across a range of compositions in mixed-species seagrass beds. Green turtles showed a clear preference for native seagrass species, particularly Syringodium filiforme, over the invasive seagrass. Both $H$. stipulacea and macroalgae were generally avoided. However, $c a .12 \%$ of individuals foraged at rates above those predicted by availability on $H$. stipulacea, suggesting that turtle foraging preferences vary at the individual level. Our results provide the first support for the resource-enemy release hypothesis in a marine system and that green turtle foraging likely facilitates the $H$. stipulacea invasion at this stage of its spread.
\end{abstract}




\section{Introduction}

Across a wide array of ecosystem types, grazers of multiple body sizes can structure primary producer communities in ways that have profound consequences for other organisms and ecosystem dynamics (Jones, Lawton, \& Shachak, 1994). In terrestrial ecosystems, large grazers can indirectly affect ecosystems by changing biomass through consumption or trampling, thus maintaining habitat heterogeneity that other plant and animal species depend on (see review by Dirzo et al., 2015). Grazers can also affect invasion dynamics within ecosystems, but the nature of these effects can vary widely. Fundamental to the overall effect an invasive species has on an ecosystem is its ability to outcompete native species and spread widely. The Enemy Release Hypothesis posits that an invasive species' ability to proliferate in a new habitat is facilitated by a lack of enemies (Cogni, 2010; Keane \& Crawley, 2002). In the case of invasive plants, if grazers preferentially feed on native species rather than invasive species, they can facilitate invasions by opening up space for the non-native plant to invade. The facilitation effect might be particularly pronounced if native species abundance and biomass is strongly shaped by herbivory (Gruner et al., 2008). If, however, grazers forage indiscriminately, or even prefer to forage on invaders, an invasion may be slowed, minimized, or even halted.

In some cases, grazers can help prevent or attenuate invasions. For example, domesticated terrestrial grazers, such as goats, are being used as a means of invasive plant species control and removal (Silliman et al., 2014). Native grazers also can mitigate plant invasions by limiting their spread or their performance (Parker, Burkepile, \& Hay, 
2006). In some grasslands, rodent herbivory on invasive species lessens the effects of invasions on community structure and productivity (Maron et al., 2014). In contrast, Canada geese (Branta canadensis moffitti) preferentially feed on native cordgrass (Spartina foliosa) over an invasive Spartina hybrid grass (Grosholz, 2010). Grazing by the Canada geese reduced above ground biomass and stem hight of the native cordgrass but left the invasive hybrid untouched thereby facilitating the invasion of the hybrid. The variability of grazer impacts on habitats disturbed by invasive species suggests contextdependence upon both the characteristics of the invasive plant species and the foraging tactics of native grazers.

In marine ecosystems, herbivorous fish and invertebrates can alter community dynamics. In coral reef communities, this occurs through grazing on macroalgae that compete with hard corals for space (see review by McCook, Jompa, \& Diaz-Pulido, 2001). Sea urchins can cause the collapse of kelp forest ecosystems when their natural predators, sea otters (Enhydra lutris), are removed (Estes \& Palmisano, 1974). Similarly, large marine grazers (dugongs, Dugong dugon, and green turtles, Chelonia mydas) modify the structure (e.g., biomass, species composition) and function (e.g., nutrient cycling) of seagrass ecosystems (Burkholder, Heithaus, Fourqurean, Wirsing, \& Dill, 2013; De Iongh, Kiswara, Kustiawan, \& Loth, 2007; Preen, 1995; Thayer, Engel, \& A. Bjorndal, 1982).

As adults, green turtles are mostly herbivorous but exhibit considerable variation within and among populations throughout their range (for a review see Jones \& Seminoff, 2013). Some green turtle populations specialize on seagrasses and select for seagrass 
blades that are high in protein (good nutritional value) and low in lignin content (easy digestibility) (Bjorndal, 1980; Fuentes, Lawler, \& Gyuris, 2006). Other populations specialize on macroalgae (López-Mendilaharsu, Gardner, Seminoff, \& RiosmenaRodriguez, 2005; Santos et al., 2011), and some forage on a mix that may even include invertebrates (Arthur \& O’Neil, 2007; Burkholder, Heithaus, Thomson, \& Fourqurean, 2011; Hatase et al., 2002; Seminoff, Resendiz, \& Nichols, 2002). Despite the strong support for specialization at the population level, most diet studies also include evidence of persistent variability among individuals (individual specialization $e . g$., Burkholder $e t$ al., 2011).

Of particular concern is how changes in large grazer abundances - both negative through overharvesting and positive through conservation coupled with the loss of predators on large turtles - might affect seagrass ecosystem structure and function (e.g., Heithaus et al., 2014; Heithaus et al., 2008; Jackson, 2001). Also, of growing concern is the little-known potential role of green turtles and other large marine grazers in facilitating or attenuating marine plant invasions.

Halophila stipulacea, a seagrass native to the western Indian Ocean, the Persian Gulf and the Red Sea, has successfully spread to the Mediterranean and southern Caribbean. Possibly transported by pleasure yachts, it is one of only two seagrass species known to have transoceanic establishment (Ruiz \& Ballantine, 2004). The invasive $H$. stipulacea is fast-growing, produces a large numbers of seeds, can spread quickly vegetatively, and can tolerate a wide range of salinities, temperatures, light levels, and disturbance regimes (Short et al., 2010). These factors have contributed to its rapid 
expansion in the Caribbean since its initial sighting in Grenada in 2002 (Ruiz \& Ballantine, 2004). As of 2017, it had been documented throughout the Lesser Antilles and as far north as Puerto Rico (Ruiz, Ballantine, \& Sabater, 2017). In its native range, $H$. stipulacea is readily consumed by dugongs (Short $e t$ al., 2010), but $H$. stipulacea could be released from this 'enemy' pressure in the Caribbean if green turtles do not recognize it as a potential food source or preferentially consume native seagrasses.

Given the observed plasticity in diets, green turtle feeding behavior might be expected to change in the presence of novel species. Hawaiian green turtles, for example, forage on the non-native Halophila dicipiens (Russell et al. 2003) and seven non-native species of macroalgae that now make up the majority (64\%) of their diets (Russell \& Balazs, 2015). Invasive species that quickly spread in Hawaii were incorporated into turtle diets over $c a$. a decade, and those that took longer to become established entered diets later (20-30 years). The incorporation of invasives into the diets of Hawaiian green turtles over time suggests that green turtle dietary preferences are determined, at least in part, by the abundances of forage species.

Because $H$. stipulacea is highly invasive and has been present in high abundances in parts of the Caribbean for over a decade, it might be expected that Caribbean green turtles would have incorporated $H$. stipulacea into their diets. However, 3-6 years after the first documentation of $H$. stipulacea in Bonaire (Dutch Caribbean) (Debrot et al., 2012), cafeteria experiments revealed that green turtles selectively feed on the native seagrass Thalassia testudinum when presented with samples of each locally available seagrass (native: T. testudinum and Syringodium filiforme, invasive: H. stipulacea) in 
equal proportions (Christianen et al., 2018). Despite the higher nutritional value observed in T. testudinum, two out of the 20 grazing green turtles did forage on the invasive $H$. stipulacea, and three foraged on S. filiforme. Additionally, satellite imaging revealed that green turtles expanded their grazing patches to include shallow, previously ungrazed $T$. testudinum after the local establishment of $H$. stipulacea. These results suggest that green turtles show individual variability with an overall preference for one nutrient-rich native seagrass. However, it is still unclear whether turtles preferentially forage on native or invasive seagrasses of similar nutritional value or forage indiscriminately across a range of forage species availability and composition.

Here, we used natural spatial variation in the relative abundance of native and invasive seagrasses within a nearshore green turtle foraging habitat to test a priori predictions about green turtle foraging preferences (Figure 1), and whether H. stipulacea might benefit from enemy release. Specifically, we used focal follows of individual green turtles to test whether 1) they prefer native seagrasses regardless of seagrass relative abundances (and, therefore, likely facilitate the invasion); 2) they prefer the invasive seagrass (and might attenuate the invasion); 3) they prefer most abundant seagrass (and may facilitate coexistence); or 4) show no obvious foraging preferences (which would favor the most herbivory-resistant species or coexistence of both species) (Figure 1). 


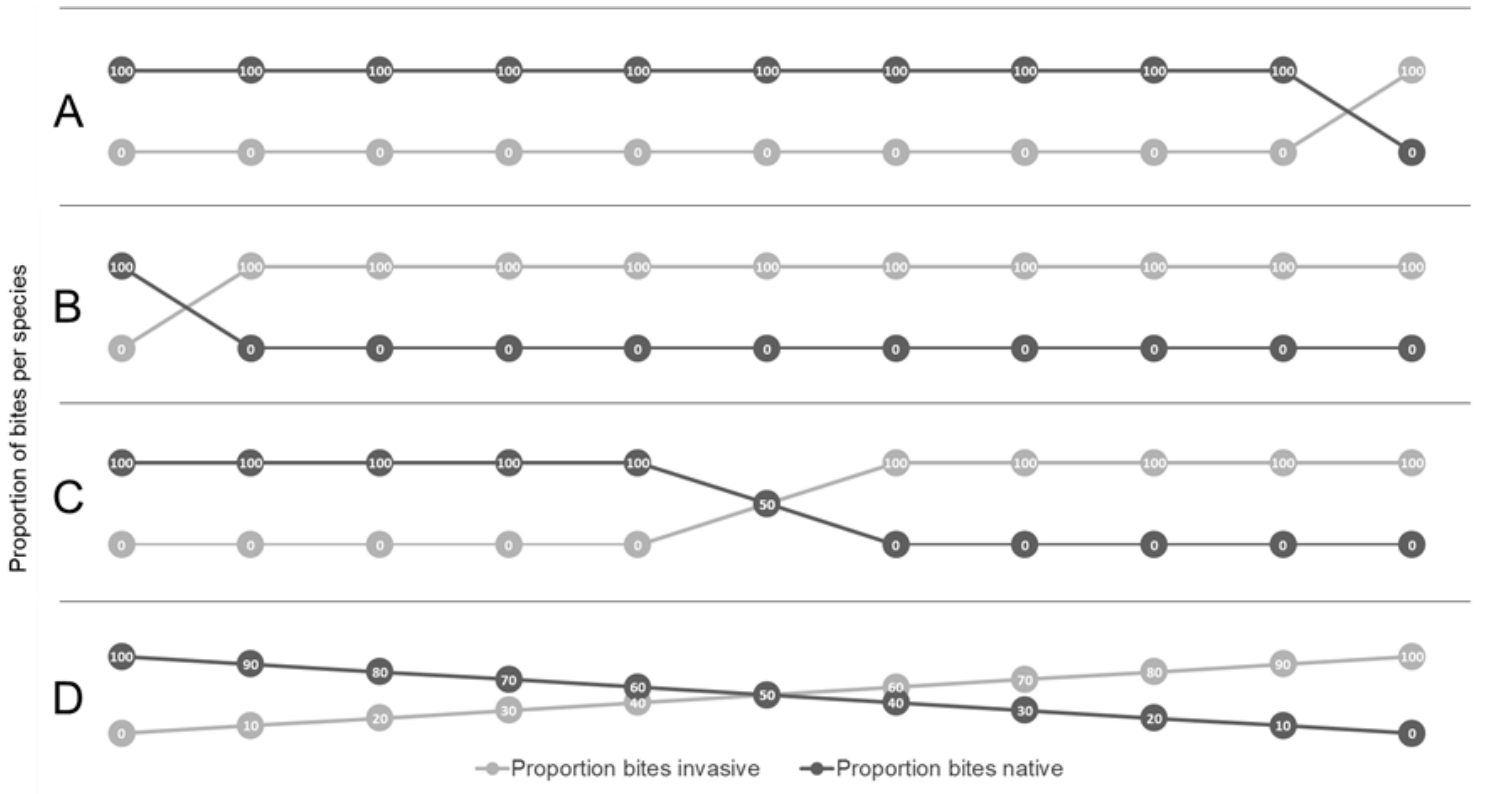

Figure 1. Conceptual diagram of predicted green turtle foraging behavior on two species if they A) prefer native seagrasses (dark circles), B) prefer invasive seagrass (gray circles), C) preferential to forage on the most abundant species, and D) display no foraging preference. Note, in (A) we assume that turtles would forage on the invasive species if it were the only forage available.

\section{Methods}

Study site

We conducted our study in Malendure Bay, along the western coast of Basseterre, Guadeloupe, French West Indies (Figure 2). The mouth and widest width of the Bay spans $c a .750 \mathrm{~m}$ and a beach lines $c a .500 \mathrm{~m}$ of the inner coast. Seagrass is found between depths of 2-10 m and covers $c a .12$ ha of the study area. Native seagrasses found in Malendure Bay include S. filiforme, T. testudinum, and Halodule wrightii. The 
invasive seagrass H. stipulacea was first observed in Guadeloupe in 2010 (Kerninon, 2012).

Green turtles from multiple life stages - including juvenile, subadult and adult turtles, and nesting females - are found off Guadeloupe (Carr et al., 1982; Meylan, 1983). The beach at Malendure Bay is not a regular nesting site (Rinaldi et al., 2011), but an important foraging ground for juvenile and subadult green turtles. Malendure Bay is a popular tourist destination, in part because green turtles are abundant and highly acclimated to the presence of boats, snorkelers, and divers.

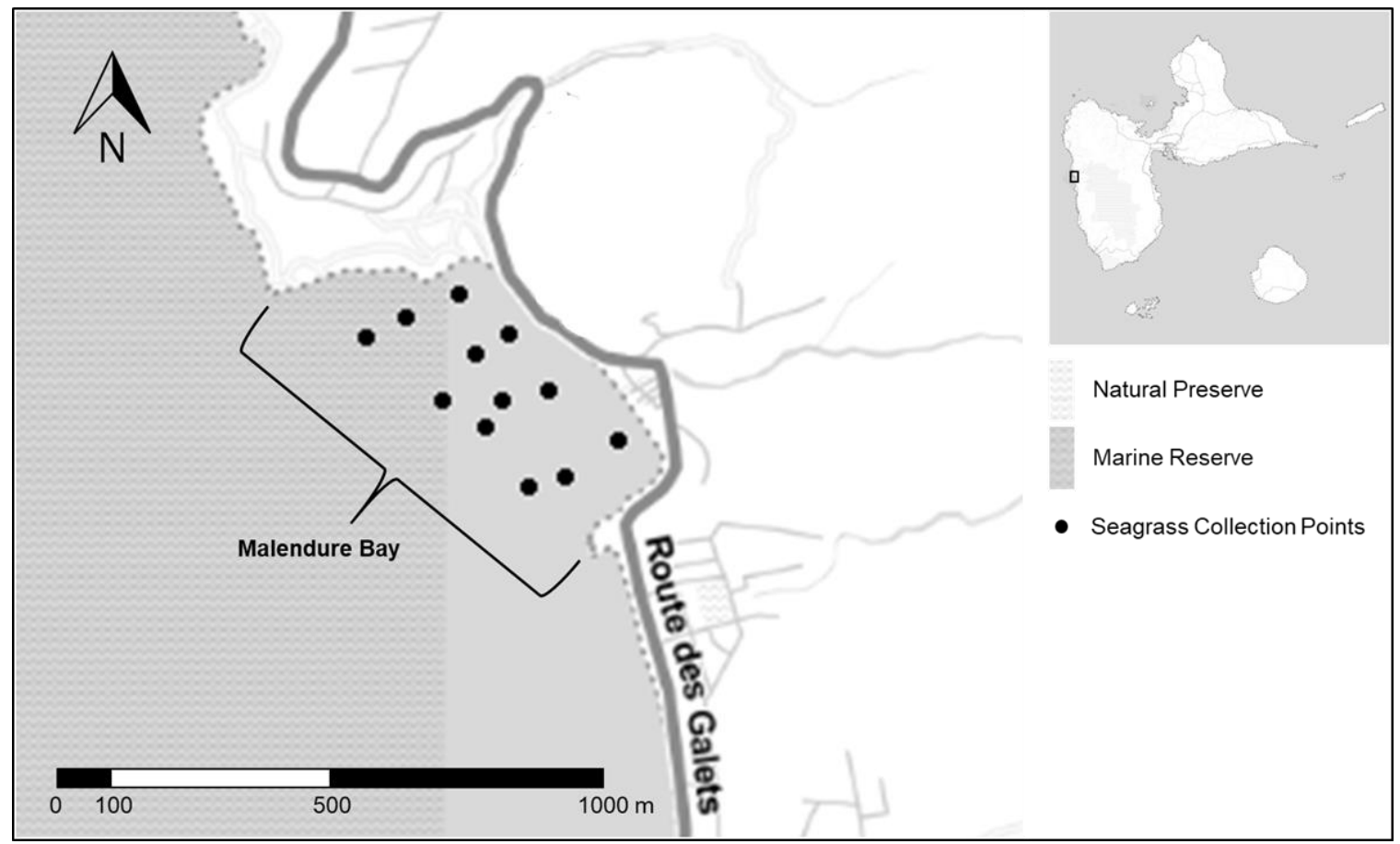

Figure 2. Malendure Bay lies on the west coast of Guadeloupe (inset). Seagrass nutrient content was measured at 12 locations within the study area (closed circles). 


\section{Focal follows}

Focal follows were conducted on 10 days in 2015 (March: $\mathrm{n}=5$ days; April: $\mathrm{n}=5$ days) and 12 days in 2016 (June: $n=3$ days; July: $\mathrm{n}=7$ days; August: $\mathrm{n}=2$ days). During a follow, trained observers used GoPro® Hero 1+ video cameras attached to a $2 \mathrm{~m}$ extendable pole at a $90^{\circ}$ angle. Observers entered the water at predetermined, random starting points along the shoreline and swam for a predetermined, random, amount of time before actively searching for a turtle. Upon spotting a turtle, the video recording was initiated, the pole was extended to $\sim 2 \mathrm{~m}$, and the camera was oriented to record the turtle's head. If the turtle reacted to the presence of the observer or the camera, the observer moved 1-2 m further away from the turtle but continued recording. If the turtle resumed normal behavior (e.g., foraging, resting) within a few minutes, the observer would re-approach and continue the recording; if not, the follow was terminated and another turtle was located. During follows, the observer attempted to record the species turtles were consuming and attempted to minimize their movements and noises. Observers remained at the surface throughout follows to minimize disturbance. We followed each turtle for 35 minutes or until human disturbance caused the turtle to flee or the turtle moved into areas that were unsafe to snorkel (e.g., channels with high boat traffic). At the end of the follow, the observer marked a GPS point and began searching for another individual to follow. 


\section{Video data extraction}

We excluded follows that contained less than $90 \mathrm{sec}$ of foraging behavior and segments of follows where it was not possible to determine macrophyte species composition. Individuals were identified using a combination of carapace scute patterns and profile scale patterns. Turtle behaviors were classified as: 1) 'foraging' if the turtle was biting, chewing and swallowing; 2) 'surfacing' when swimming to and from the surface and time spent at the surface; 3) 'traveling' if swimming horizontally or if vertical movements were not associated with surfacing; and 4) 'resting' when stationary and not foraging. For each foraging bout (i.e., time of continuous feeding, between surfacing or traveling events), we estimated the abundance of each macrophyte species present by averaging the percentage cover at observations taken every 60 seconds for both the full field of view and for the cover immediately available to the individual (Figure 3). We quantified foraging behavior using the number of bites taken within each foraging bout and classified the species consumed as macroalgae, T. testudinum, H. stipulacea, $S$. filiforme, mixed (i.e., bite containing two or more macrophyte species), unknown (i.e., targeted food item could not be identified), or other (e.g., shells, garbage, gelatinous plankton). Although $H$. wrightii is present in Malendure Bay, it was not observed during our focal follows and is not included in the analysis. Videos were viewed in their entirety by one observer and subsections of the videos were viewed by an additional observer to validate macrophyte identification and abundance estimates. 


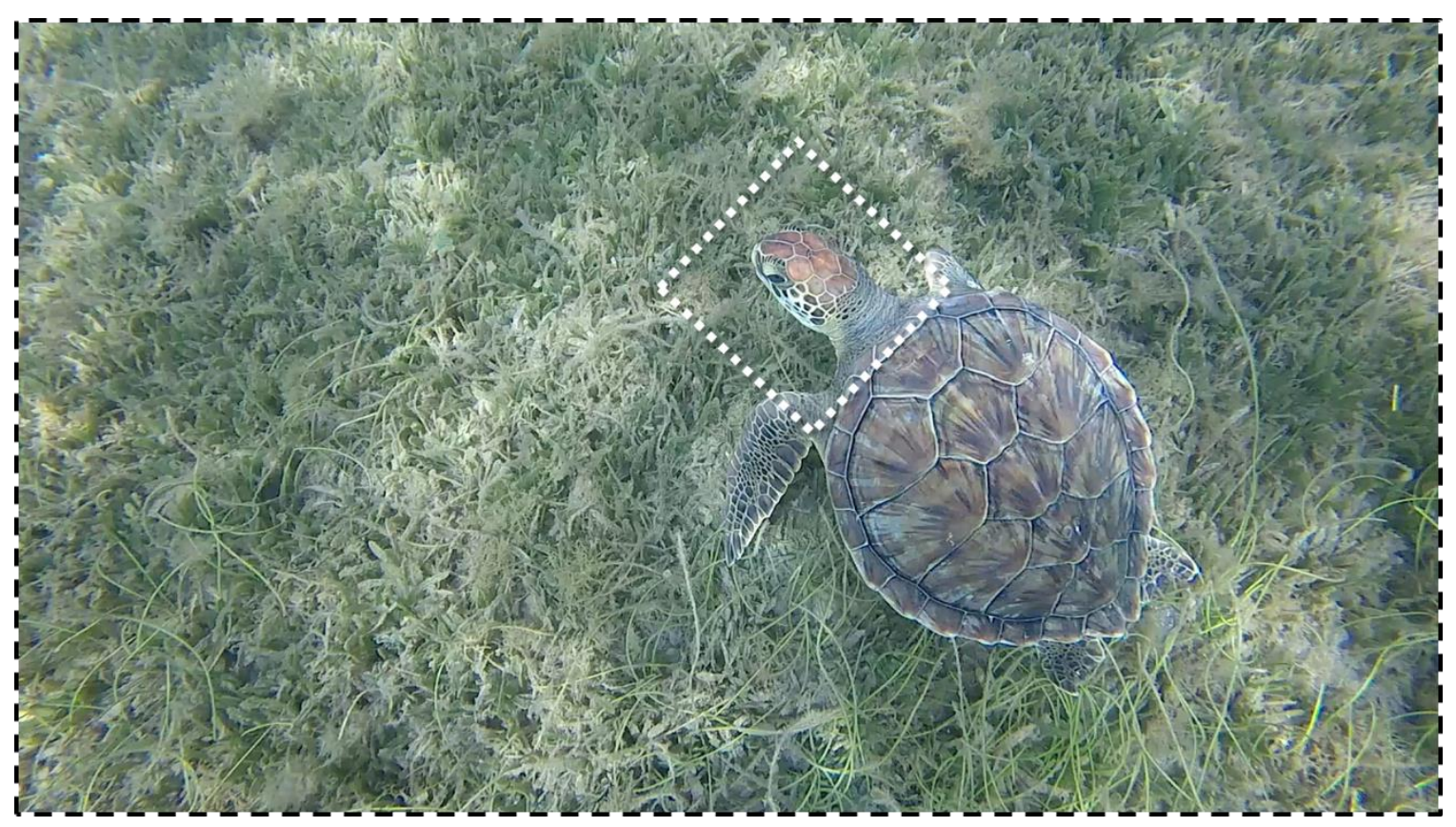

Figure 3. Screen grab from a video of a green turtle during a focal follow. The outer box delineates the entire viewing area used for estimates of percent cover (i.e., the entire field of view). The white dotted line, defined by a box extending from between the foreflippers to several $\mathrm{cm}$ in front of the turtle's head, delineates the area immediately available to the turtle for foraging and was used for the estimates of percent cover for each seagrass species that were used for analysis.

\section{Nutrient content analysis}

In 2016, we collected all macrophyte species present at each of 12 points

throughout the Bay (Figure 2). Macrophyte samples were frozen immediately upon return to shore for storage until further processing. Samples were cleaned of epiphytes and dried in a food-grade dehydrator for a minimum of 24 hours within 48 hours of collection.

After drying, samples were crushed using a mortar and pestle and stored in airtight vials for transport back to the laboratory. Total $\mathrm{C}$ and $\mathrm{N}$ were measured using a CE Flash 1112 elemental analyzer using standard procedures, and total $\mathrm{P}$ was analyzed colorimetrically 
following modified methods from Solórzano and Sharp (1980) on a Shimadzu UV2101PC spectrophotometer.

\section{Data analysis}

We compared foraging preferences using bite rates on each species both among individual turtles and across varying macrophyte community compositions. The mean percent cover of each macrophyte species present near the turtle and the total number of bites on each macrophyte taxa were calculated per foraging bout.

We used the R package (R Core Team, 2016) adehabitatHS (Calenge, 2006) design III selectivity analysis to test the effects of species composition (resource availability) on foraging (resource use). Because of the low occurrence of bites of mixed species, bites of unknown species, and feeding on marine debris and animal matter (i.e., ctenophores, shells), these were not included in analyses. The native seagrass $T$. testudinum was also excluded from the selectivity analyses because it was only encountered once by each of two turtles. Only one of these turtles foraged on $T$.

testudinum. Mean percent cover within each follow (defined by small box, Figure 3) was used as the resource availability input, and the mean number of bites $* \min ^{-1}$ for each foraging bout within each follow was used as the resource use input.

Assuming uniform use of habitats as the null hypothesis, resource use was tested for the population and for individuals using Chi-square goodness-of-fit tests. We calculated Manly's selection ratios (Wi) with Bonferroni confidence intervals with 
resources defined by the categories $H$. stipulacea (Hs), S. filiforme (Sf), and Macroalgae (Calenge, 2015). Ratios (resource use to resource availability) $>1$ indicate selection and $<1$ indicate avoidance. Ratios near 1 or confidence intervals for the population overlapping 1 suggest no selectivity.

To test our four mutually exclusive hypotheses (Figure 1), we quantified the effects of seagrass community composition to our proxy for preference, proportion of bites taken of each species (per bout and cumulative). Data on relative abundance of each macrophyte $(\%)$ were tested for normality with Shapiro Wilk's tests. The inability to achieve a normal distribution after multiple transformation attempts and high dispersion of our data lead us to use generalized linear regression (quasipoisson). Akaike's Information Criterion (AIC) scores were used to determine best model fit.

We assed variation in $\% \mathrm{~N}, \% \mathrm{C}$, and $\% \mathrm{P}$ of dry weight and the $\mathrm{C}: \mathrm{N}, \mathrm{C}: \mathrm{P}$, and $\mathrm{N}: \mathrm{P}$ ratios among macrophytes used in the selectivity analyses (S. filiforme, H. stipulacea, and macroalgae) with an ANOVA. All data were tested for normality using Shapiro-Wilk's tests. The non-normal distribution in $\% \mathrm{C}$ and $\mathrm{C}: \mathrm{P}$ of macroalgae and in $\mathrm{N}: \mathrm{P}$ of $H$. stipulace $a$ were rectified using a $\log _{10}$ transformation on all \%C, C:P, and N:P data. Back transformations were performed for display of results. We used Tukey's HSD corrections, with alpha value set at 0.05 , for all pairwise comparisons (Appendix I). 


\section{Results}

In 2015, H. stipulacea was found at 22 of $23(96 \%)$ haphazardly selected survey points distributed throughout Malendure Bay, and by 2016 it was found at 60 of 64 (94\%) survey points from two sampling events. The $\% \mathrm{~N}$ and $\% \mathrm{P}$ dry weight of $S$. filiforme and H. stipulacea were significantly greater than those of macroalgae $\left(\mathrm{N}: F_{2,27}=29.8 ; P<\right.$ $\left.0.0001 ; \mathrm{P}: F_{2,27}=83.3 ; P<0.0001\right)$, and all species varied significantly from one another in $\% \mathrm{C}$ dry weight $\left(F_{2,27}=101.0 ; P<0.0001\right)$. There were no significant differences among species for the ratio of $\mathrm{C}: \mathrm{N}\left(F_{2,27}=1.71 ; P=0.20\right)$, but ratios of $\mathrm{C}: \mathrm{P}$ and $\mathrm{N}: \mathrm{P}$ were significantly higher in macroalgae than in the two seagrasses $\left(\mathrm{C}: \mathrm{P}: F_{2,27}=49.7 ; P=\right.$ $<0.0001 ; \mathrm{N}: \mathrm{P}: F_{2,27}=37.3 ; P=<0.0001$ ) (Figure 4). Both seagrass species were rich in nutrients relative to carbon, with $\mathrm{C}: \mathrm{P}$ ratios $<500$ and $\mathrm{C}: \mathrm{N}$ ratios $<20$, indicating nutrientrich conditions (Atkinson \& Smith, 1983; Johnson, Heck, \& Fourqurean, 2006). Epiphyte loads were low on all samples collected, and so were unlikely to affect forage selection. 
$\% \mathrm{C}$

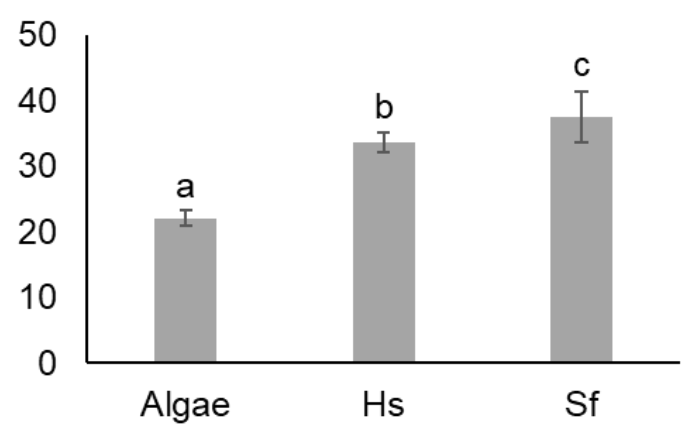

$\% \mathrm{~N}$
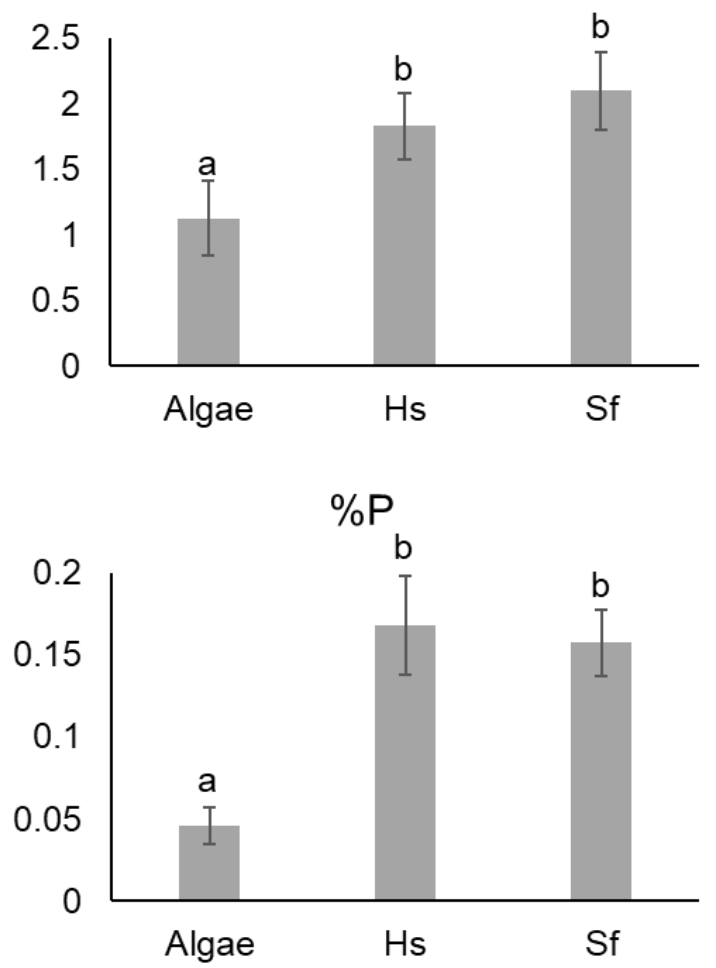

$\mathrm{C}: \mathrm{N}$

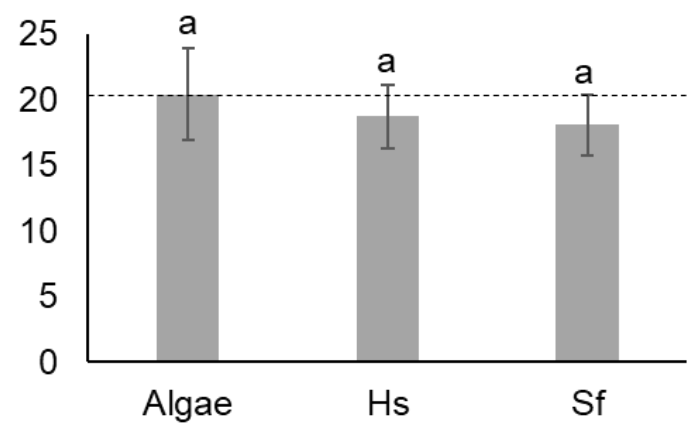

$C: P$

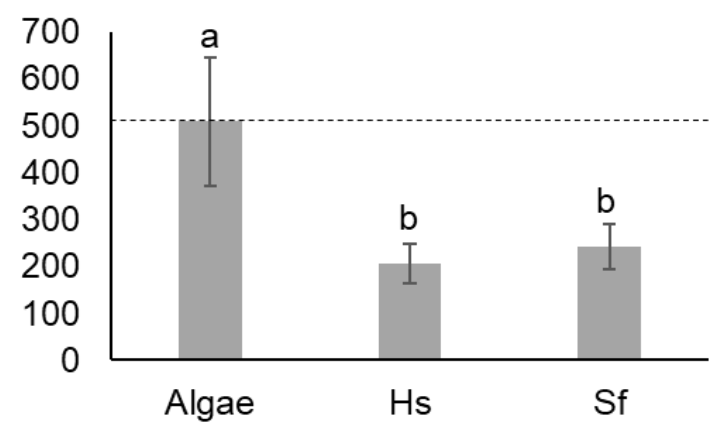

$\mathrm{N}: \mathrm{P}$

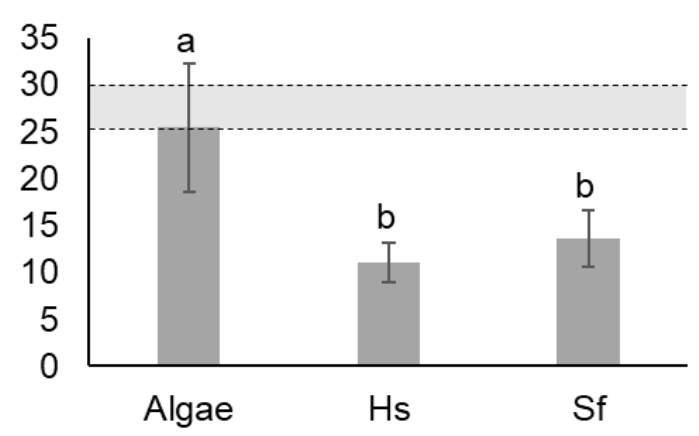

Figure 4. Left: Mean nutrient compositions ( $\pm \mathrm{SD}$ ) for macroalgae (Algae, $N=9$ ), $H$. stipulacea (Hs, $N=12$ ), and S. filiforme ( $\mathrm{Sf}, N=9$ ). Bars with different letters were significantly different from one another based on multiple post-hoc comparisons using the Tukey HSD test with alpha $=0.05$; Right: Elemental ratios of macrophyte tissue, dotted lines indicate seagrass Redfield ratios

Throughout our study we only observed foraging juvenile and subadult green turtles. A total of 70 follows resulted in $c a .12 .5$ hours of video footage, including 7.3 
hours of foraging activity from 125 total bouts. We identified 35 individuals from 45 focal follow videos (mean video length $=16$ minutes) that we included in the analyses. Four individuals were observed during two separate follows each, and two individuals were observed during four separate follows each (Figure 5). To avoid pseudoreplication, we pooled the multiple follows for these six turtles for population-level analyses. We compared multiple follows within individuals to assess selectivity over time. The total number of foraging bouts across all follows of individuals ranged from one to six.

Macrophyte abundance estimates for the full field of view differed significantly from the cover immediately available to the individual (Wilcoxon Paired Signed-Rank Test, H. stipulacea: $V=36794, P<0.0001 ;$ S. filiforme: $V=45674, P=0.024$; macroalgae: $V=36748, P<0.0001)$. The mean relative abundance of the invasive $H$. stipulacea was greater in the full field of view $(43.76 \% \pm 1.03 \mathrm{SE})$ than in the area immediately available to the turtle $(36.55 \% \pm 1.24 \mathrm{SE})$, while the mean relative abundance of the native $S$. filiforme was lower in the full field of view $(15.79 \% \pm 0.66$ $\mathrm{SE})$ than in the area immediately available to the turtle $(17.41 \% \pm 0.84 \mathrm{SE})$, and the mean relative abundance of macroalgae was greater in the full field of view $(13.53 \% \pm 0.46 \mathrm{SE})$ than in the area immediately available to the turtle $(11.21 \% \pm 0.70 \mathrm{SE})$. Because the camera was focused on the turtle's head and the area in the field of view varied depending on the water depth and our distance from the turtle, we chose to use the relative abundance of macrophytes immediately available to the individual for the selectivity analysis. 


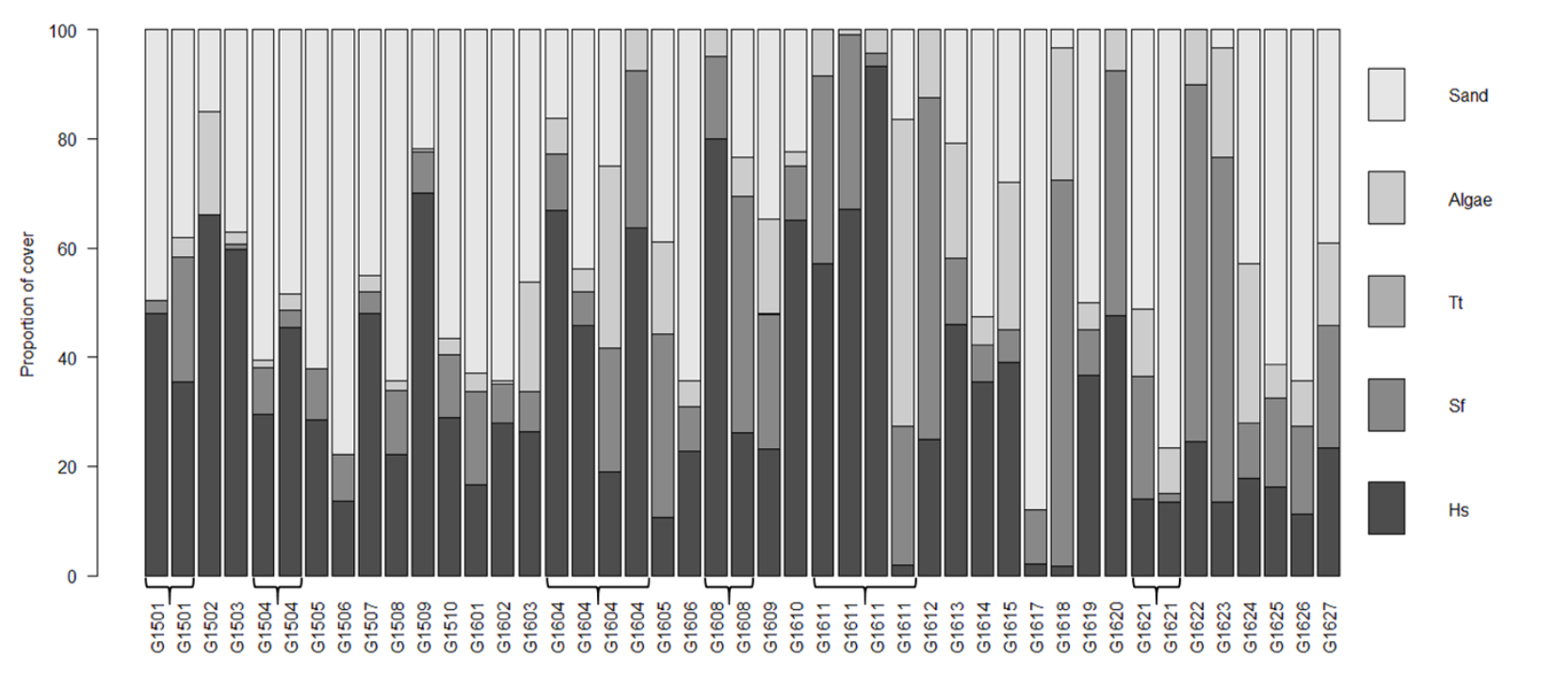

Figure 5. Mean macrophyte composition immediately available to each individual turtle during focal follows; area not covered by macrophytes (Sand), macroalgae (Algae), $T$. testudinum (Tt), S. filiforme (Sf), H. stipulacea (Hs); brackets indicate multiple follows of individuals

At the population level, green turtles in Malendure Bay had a strong and significant preference for the native seagrass ( . filiforme) over the invasive seagrass and macroalgae $(K h i 2 L=708.45, d f=32, p=0.000$; Figure 6). Indeed, the mean selection ratios for $S$. filiforme, $H$. stipulacea, and macroalgae were $3.83 \pm 0.35 \mathrm{SE}, 0.23 \pm 0.07$ $\mathrm{SE}$, and $0.09 \pm 0.03 \mathrm{SE}$, respectively. Turtles encountered both seagrass species during every focal follow and macroalgae in 42 of the 45 follows (Figure 5). However, green turtles showed a preference (greater proportion of bites) for S. filiforme regardless of its relative abundance when in mixed meadows with $H$. stipulacea $\left(\mathrm{McNemar}\right.$ 's $X^{2}=54.15$, df $=1, P<0.0001 ;$ Figure 7). Turtles occasionally foraged on the invasive $H$. stipulacea, primarily in monospecific meadows. When foraging in these monospecific meadows, however, the bite rates of turtles (mean $=9.70$ bites $* \min ^{-1}$; Figure 8 ) were less than half 
those of turtles foraging in meadows composed exclusively of native seagrass (mean = 20.9 bites $* \min ^{-1}, t=5.14, d f=18.7, P \leq 0.001$.

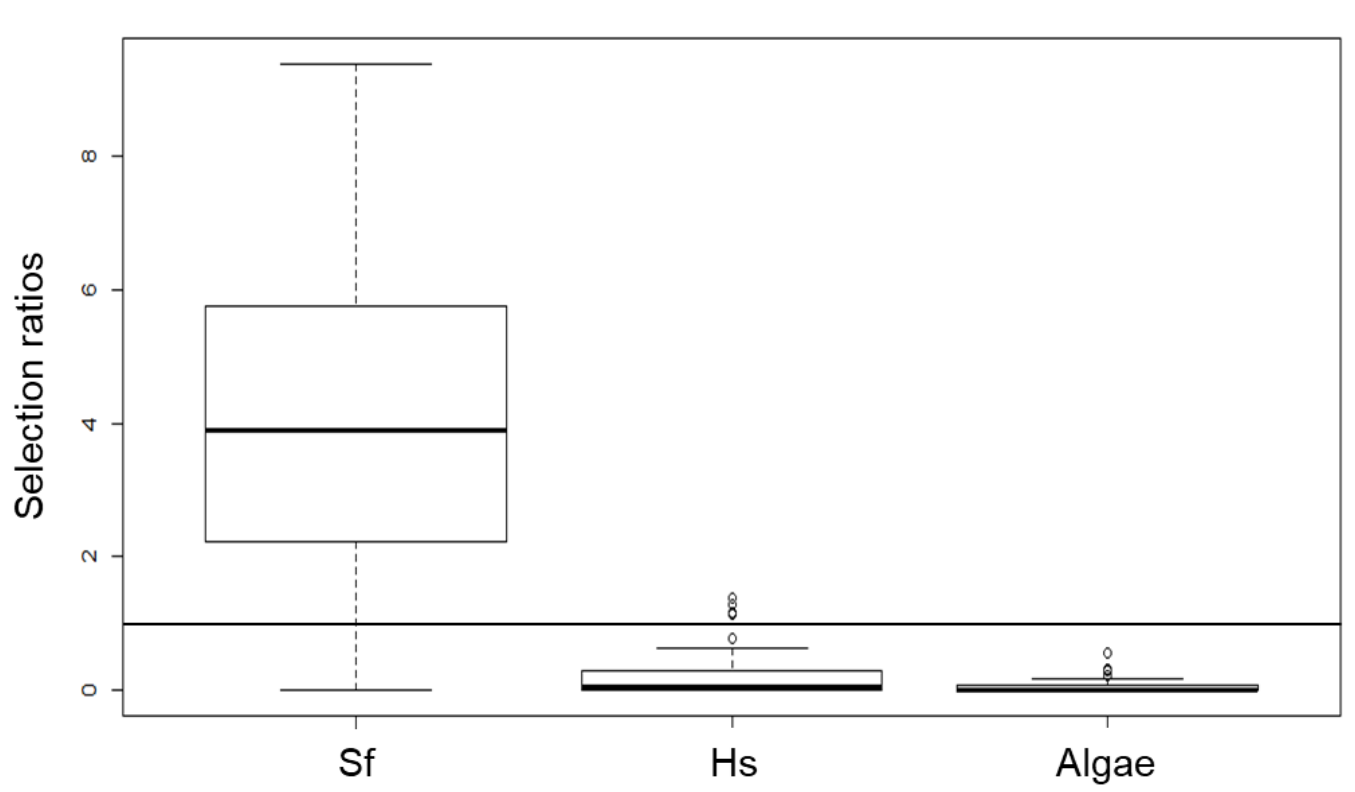

Figure 6. Selection ratios for S. filiforme (Sf), H. stipulacea $(\mathrm{Hs})$, and macroalgae (Algae); Values above 1.0 indicate positive selection, values below 1.0 indicate avoidance, and values near 1.0 indicate no apparent preference

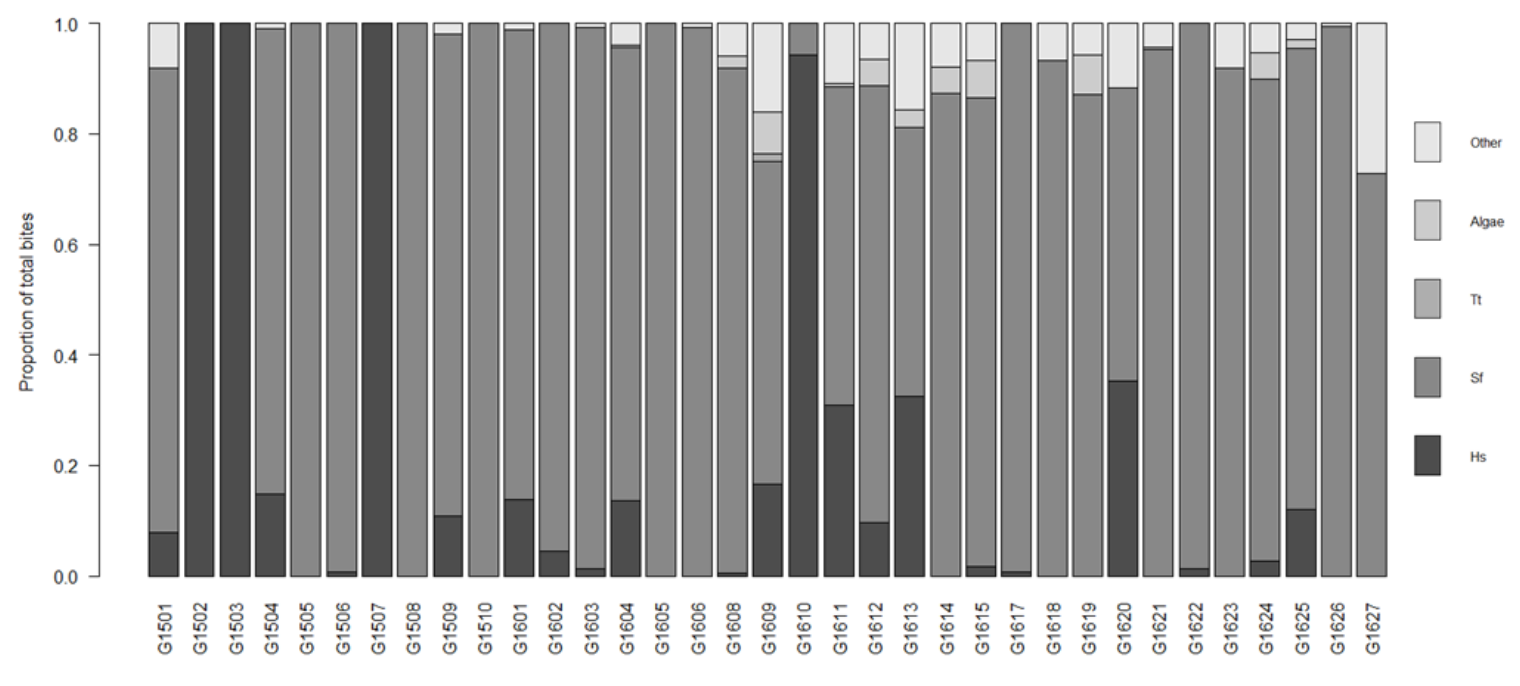

Figure 7. Proportion of total bites taken of each species for each turtle including macroalgae (Algae), T. testudinum (Tt), S. filiforme (Sf), H. stipulacea (Hs), and "other" (unknown, mixed species and non-flora combined) 


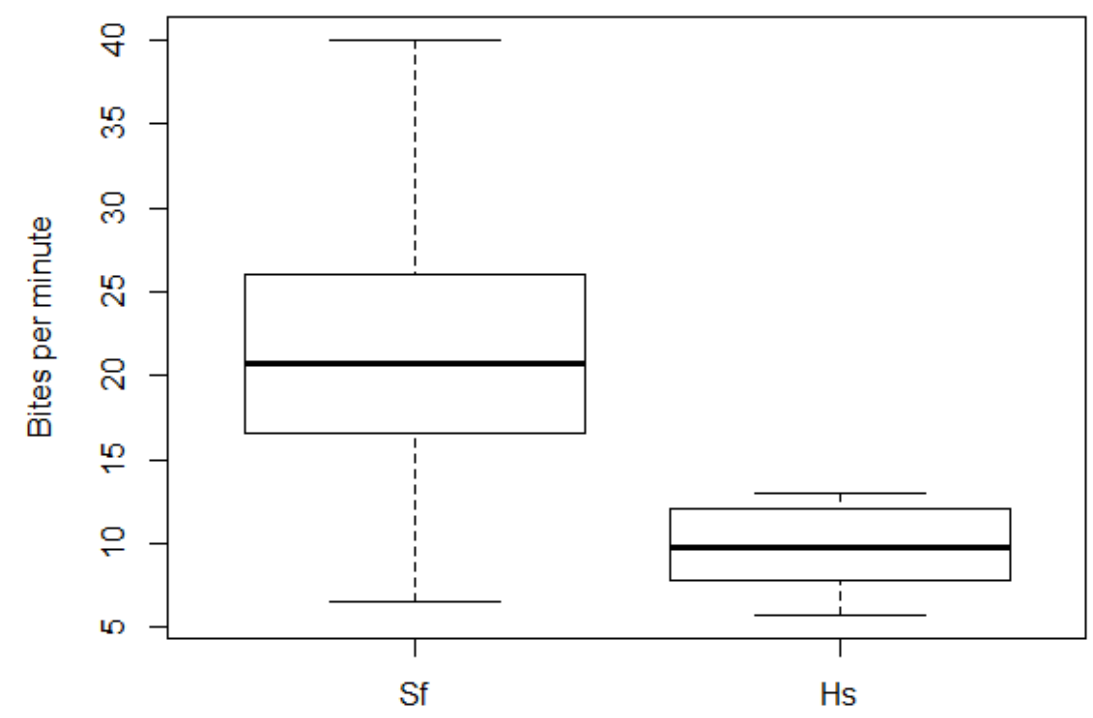

Figure 8. Bites per minute in monospecific meadows of $S$. filiforme (Sf) and H. stipulacea $(\mathrm{Hs})$

Individual-level selectivity was very similar to population-level patterns overall. Indeed, there was significant selectivity by 30 of 35 individuals (Appendix II), with 27 individuals positively selecting $(W i>1)$ for the native $S$. filiforme, three individuals positively selecting $(W i>1)$ for the invasive $H$. stipulacea, and all 35 individuals avoiding algae $(W i<1)$. Individual selectivity of resources was stable across multiple follows for four individuals that all positively selected for S. filiforme. Selection indices changed between follows for two turtles (Appendix III). One individual (G1608) positively selected macroalgae during the first follow, encountered and avoided it during the second follow, and overall (pooled follow data) avoided macroalgae and positively selected S. filiforme. Another individual (G1611) encountered and avoided the invasive seagrass $H$. stipulacea during the first, second, and fourth follows, neither selected nor 
avoided it during the third follow ( $W i \approx 1)$, and overall did not feed selectively. Turtle G1611 also positively selected the native S. filiforme during the first, second, and fourth follows, encountered and avoided it during the third follow, and overall selected for $S$. filiforme.

The combination of predictor variables that produced the lowest AIC score for all GLMs included the relative abundances (as percent macrophyte cover) of the native seagrass $S$. filiforme, the invasive seagrass $H$. stipulacea, and macroalgae (Table 1$)$. No single predictor variable or combination of predictor variables significantly affected the number of bites taken per bout of the invasive $H$. stipulacea (Table 1 ). The relative abundance of $H$. stipulacea did significantly affect the number of total bites taken per bout and the number of bites taken per bout of native $S$. filiforme were significantly affected by the relative abundances of $H$. stipulace a and $S$. filiforme as well as the interaction between the relative abundances of $H$. stipulacea and S. filiforme.

Table 1. $P$ values from GLM testing the effect of relative abundance on the number of bites taken (Factor); Hs (H. stipulacea), Sf (S. filiforme), and Algae (macroalgae) and all possible interactions were tested; asterisks represent significant affects

\begin{tabular}{lrcrrrrrr} 
Factor & df & Hs & Sf & Algae & Hs x Sf & Hs x Algae & Sf x Algae & Hs x Sf x Algae \\
\hline Total bites & 124 & $0.001 *$ & 0.160 & 0.685 & 0.120 & 0.811 & 0.334 & 0.501 \\
Bites of Hs & 124 & 0.370 & 0.866 & 0.234 & 0.995 & 0.350 & 0.270 & 0.457 \\
Bites of Sf & 124 & $<0.001 *<0.001 *$ & 0.662 & $0.016 *$ & 0.804 & 0.786 & 0.624 \\
\hline
\end{tabular}

Using the number of bites taken, green turtle foraging behavior in Malendure Bay is most consistent with a preference for native seagrasses regardless of its abundance 
relative to invasive seagrasses (Figure 9). Indeed, although turtles foraged on invasive seagrasses, this occurred primarily in monospecific stands and they foraged preferentially on native seagrasses even when it was present in low relative abundances.

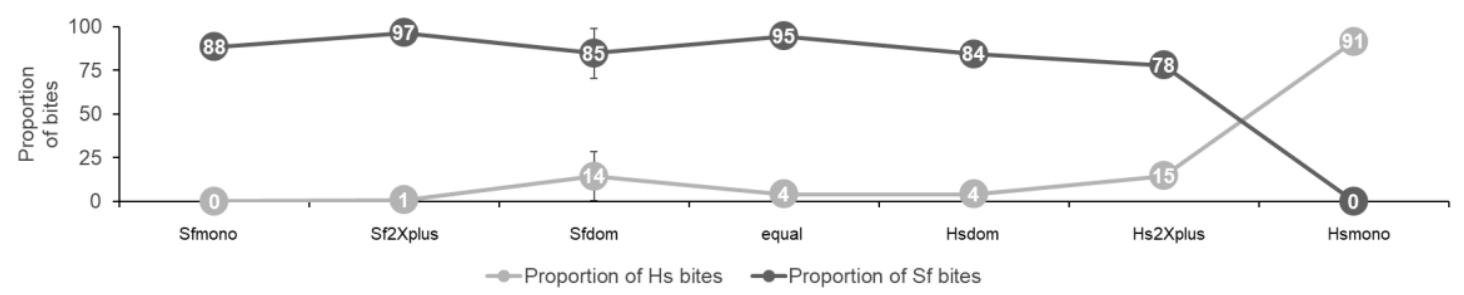

Figure 9. Mean percentage of bites $( \pm \mathrm{SE}$ ) of Hs (orange) and Sf (blue) per bout across a range of relative availabilities. Total percentages less than 100 are due to bites of taxa other than seagrass. Error bars are SE, and are not visible when smaller than the size of the data point. Sfmono $=100 \% \mathrm{Sf}, \mathrm{Sf} 2 \mathrm{Xplus}=\mathrm{Sf} \geq 2 \times \mathrm{Hs}=75-99 \% \mathrm{Sf}$, Sfdom $=2 \times \mathrm{Hs}$ $>\mathrm{Sf}>\mathrm{Hs}=51-74 \% \mathrm{Sf}$, equal $=\mathrm{Sf}=\mathrm{Hs}=50 \% \mathrm{Sf}+50 \% \mathrm{Hs}$, Hsdom $=2 \times \mathrm{Sf}>\mathrm{Hs}>\mathrm{Sf}$ $=51-74 \% \mathrm{Hs}$, Hs 2 Xplus $=\mathrm{Hs} \geq 2 \mathrm{x} \mathrm{Sf}=75-99 \% \mathrm{Hs}$, Hsmono $=100 \% \mathrm{Hs}$

\section{Discussion}

Halophila stipulacea is spreading rapidly in the Caribbean (Rogers, Willette, \& Miller, 2014; Ruiz et al., 2017; Willette et al., 2014), making it important to understand the factors that might facilitate or attenuate its spread. We found that the green turtles in Malendure Bay show strong preferences (positive selection) for native seagrass over the invader across a wide range of relative abundances. Although turtles foraged on $H$. stipulacea when it was the only seagrass available, only three out of 35 individuals showed a preference for this species while most preferred the native species. Together, these data suggest that $H$. stipulacea is likely benefiting from the rare enemy effect, at 
least from megagrazers, and that green turtles could be facilitating the invasion by allowing it to spread.

There are several possible explanations for why green turtles are not foraging widely on $\mathrm{H}$. stipulacea. Turtles may not recognize it as a potential food source or be avoiding lower-quality forage. The former seems unlikely since turtles in Malendure grazed on H. stipulacea even if only three showed a preference for it, and Halophila spp. are part of the diet of green turtles in other parts of the world (e.g., Halophila ovalis in India, Agastheesapillai and Thiagarajan, 1979); H. ovalis and Halophila ovata in Oman, Ross, 2016); H. ovalis and Halophila spinulosa in Australia (Limpus et al., 1994, 1985); Halophila engelmanni in Florida, Mendonça, 2016)]. Furthermore, green turtles in other locations have shifted their diets to include invasive taxa. Hawaiian green turtles, for example, shifted their foraging behavior to include non-native species, although the shift to include some invasive species in their diets occurred up to 30 years after their introductions (Russell \& Balazs, 2009). The introduction of invasive species into the diets of Hawaiian green turtles may be related to their abundance in foraging habitats (Russell \& Balazs, 2015; Russell et al., 2003), but diet preferences have not been directly compared to resource availability in the Hawaiian population. While a similar degree of population-level dietary plasticity is not evident from our study of green turtles in Guadeloupe, some individuals foraged on the invasive seagrass and others switched preferences over time. The invasion is still relatively recent at this site (c.a. one decade). Thus, there may be enough native seagrass still available that turtles can afford to be selective, and shifts could occur at the population level over time if $H$. stipulacea proliferates to the point where S. filiforme becomes difficult for turtles to find. 
It is unclear what role forage quality might play in the diet preferences we detected. Turtles demonstrated general negative selectivity for macroalgae, which is consistent with the lower $\mathrm{N}$ content in algae than in both seagrasses. In Bonaire, green turtles selectively foraged on the abundantly and nutritionally dominant native seagrass $T$. testudinum (Christianen et al., 2018). However, if diet quality was driving differences in preferences for native over invasive seagrasses, it would have been expected that $S$. filiforme was higher in quality than $H$. stipulacea. My analyses did not reveal nutrient content as a clear driver for forage selection. Although S. filiforme did have a higher C content than H. stipulacea in Malendure, there were not statistically significant differences between the seagrasses in other measures of nutrient content. In a metaanalysis of seagrass nutrient content, $H$. stipulacea was found to have slightly greater, although still below average for all seagrasses, nitrogen content than $H$. ovalis and $H$. spinulosa (Duarte, 1990). Halophila stipulacea also had the widest range of nutrient content values reported for Halophila species, and our nutrient content results revealed that nitrogen content for $H$. stipulacea in Malendure Bay was at the high end of the range $(1.83 \% \pm 0.07 \mathrm{SE})$ and not significantly different than the nitrogen content of the Malendure native, S. filiforme ( $2.10 \% \pm 0.10 \mathrm{SE})$. Compared to the seagrass Redfield ratio, the observed $\mathrm{N}: \mathrm{P}$ ratios in Malendure were below 25, indicating N-limitation (Duarte, 1990; Fourqurean \& Cai, 2001). Anthropogenic sources such as boats discharging their holding tanks while anchored in the bay and runoff from adjacent homes and businesses likely contribute to the increased seagrass nitrogen content that we observed. Similarly, Duarte (1990) also reported a wide range of values for carbon content of $H$. stipulacea, and the mean carbon content (33.59\% \pm 0.45 SE) in Malendure 
Bay was above the average reported in their meta-analysis. The reported mean carbon content was also significantly different than the mean carbon content of S. filiforme $(37.39 \% \pm 1.29 \mathrm{SE})$ in Malendure Bay. Given that green turtle diets in other regions do include Halophila spp., the nitrogen contents of H. stipulacea in Malendure Bay are greater than average for other Halophila species Both $\mathrm{N}$ and $\mathrm{P}$ contents of $H$. stipulacea are comparable to the contents of the native S. filiforme in the Bay, and the low N:P ratio suggests that the system is $\mathrm{N}$ limited, green turtles may eventually incorporate $H$. stipulacea into their diets more broadly. It is likely, because of the reaction of the Hawaiian green turtle population to invasive plant species (Russell \& Balazs, 2009), that if $H$. stipulacea continues to spread, it will, by necessity, eventually become a major component in green turtle diets in the Caribbean. Invasive plant-herbivore interactions can be dynamic, and at the scale of whole meadows rather than patchworks, green turtles may be willing and able to switch to foraging on the invasive species. Continued monitoring of the H. stipulacea spread and green turtle foraging preferences will be necessary to understanding and predicting the broader ecosystem impacts of the invasion.

Previous studies of green turtle diets have shown that individual diets can vary over time (Brand, 1995; Fuentes et al., 2006), while others reveal that despite diverse foraging options, diets varied considerably among individuals but were consistent over time within individuals (Burkholder et al., 2011; Thomson et al., n.d.). In Malendure, only one individual switched its preference between the native and invasive seagrasses between follows. The second individual that displayed diet preference shifts between follows encountered red drift algae rather than the more commonly encountered calcareous green algae. Despite this individual variability, the population showed a clear 
preference for the native seagrass S. filiforme and clear avoidance of macroalgae and invasive seagrass $H$. stipulacea.

The spread of invasive species is not unique to the marine environment, and studies of the effects of large-bodied herbivores on plant invasions in terrestrial ecosystems reveal differences among systems and are dependent upon several factors. Some studies suggest that herbivores have little effect on plant invasions and other factors such as nutrients and disturbance play a bigger role in determining plant communities (Stohlgren, Schell, \& Vanden Heuvel, 1999). Other studies present strong evidence that grazers mitigate the invasion of dense invasive grasses that can outcompete native grasses when grazers are removed and nutrients inputs increase (Weiss, 2009). Conversely, grazing by large populations of ungulate grazers is suggested to be required for the invasion of garlic mustard (Alliaria petiolate) (Kalisz, Spigler, \& Horvitz, 2014). The conflicting results from studies in multiple terrestrial systems suggest that consideration of grazers alone is insufficient to explain the success of an invasive plant species. The resource-enemy release hypothesis (R-ERH) considers two of the most common factors credited with affecting plant invasions. The R-ERH suggests that highresource plants are particularly successful invaders because of the interaction of a high resource environment and the release from their native enemies (Blumenthal, 2005, 2006). An explicit test of the predictions of R-ERH demonstrated that resource availability and vertebrate grazers did indeed jointly influence the success of a non-native plant invasion in a field undergoing secondary succession (Heckman, Wright, \& Mitchell, 2016). 
In Malendure Bay, we found nutrient-rich conditions indicated by ratios of $\mathrm{C}: \mathrm{N}$ and C:P below the seagrass Redfield ratio in leaves from both the invasive and native seagrasses. The direct measurement of ambient nutrients is unnecessary because it is widely accepted that nutrient contents of seagrass leaves reflect relative nutrient availability (Atkinson \& Smith, 1983; Duarte, 1990), and have even been used to identify sources of nitrogen inputs to the system (Fourqurean, Moore, Fry, \& Hollibaugh, 1997). We also found that green turtles in this area, experiencing a $H$. stipulacea invasion, have a significant preference for native seagrass species, particularly S. filiforme. Green turtles in Malendure Bay are not feeding preferentially on the most abundant species or switching to prefer the most selection abundant species. Our results suggest that the spread of the invasion could be benefiting from the Enemy Release Hypothesis. When coupled with the high-nutrient resource availability found in Malendure Bay, our results provide the first support for the predictions of the R-ERH from a marine ecosystem.

We used natural spatial variation in the relative abundance of native and invasive seagrasses within Malendure Bay to test a priori predictions about green turtle foraging preferences and whether $H$. stipulacea might benefit from enemy release. Using focal follows of individual green turtles, we tested whether 1) they prefer native seagrasses; 2) they prefer the invasive seagrass; 3) they prefer most abundant seagrass; or 4) show no obvious foraging preferences. Our study reveals that the relative abundance of an invasive plant species does not always determine grazer diet preference, at least not in the initial stages of the invasion. In fact, H. stipulacea in Malendure Bay is likely benefiting from the Enemy Release Hypothesis, where native grazers play a critical role in determining how the invasion will change seagrass ecosystem functions. Similarly, in 
terrestrial systems, white-tailed deer (Odocoileus virginianus), that are typically considered to be generalist ungulate grazers, preferentially graze on native species over exotics (Kalisz et al., 2014), suggesting that large-bodied grazers across systems can facilitate plant invasions through selective feeding.

The nature of grazer-plant invasion interactions can be context-dependent and will require further studies across a diversity of ecosystems to understand the drivers of contingency of native grazer impacts on invasive species establishment and proliferation. However, our results are consistent with emerging patterns and suggest that the interaction of multiple factors, such as resource availability and enemy release, may further explain the success of an invasive marine plant species. The insights gained from our study echo those from studies from terrestrial habitats experiencing pressure from high ungulate populations (Heckman et al., 2016; Kalisz et al., 2014), and can be directly applied to ecosystems around the world where the foraging behavior of grazers - and thus their ecosystem role - can affect the success of an invasive plant species.

\section{Acknowledgments}

Thanks to the TOTAL Foundation for funding this research, to Michael Heithaus and Jeremy Kiszka for guidance throughout the project, C. Cáceres, C. Webster, Caroline Rinaldi and the interns at Association Evasion Tropicale for assisting in data collection, and Laura García Barcia and Dominique Brito for video data extraction. Research was conducted under IACUC permit \#200548. Additional permits and assistance were provided by Office National de la Chasse et de la Faune Sauvage (French Wildlife 
Service), Reseau Tortue Guadeloupe (Sea Turtle Network - Guadeloupe), DEAL

Guadeloupe, and the National Park of Guadeloupe.

\section{References}

Agastheesapillai, A., \& Thiagarajan, R. (1979). Biology of the Green turtle Chelonia mydas (Linnaeus) in the Gulf of Mannar and Palk Bay. Journal of the Marine Biological Association of India, $21(1 \& 2), 45-60$. http://eprints.cmfri.org.in/1494/\%5Cnhttp://eprints.cmfri.org.in/1494/1/Agastheesa_ 45-60.pdf.

Arthur, K. E., \& O'Neil, J. (2007). Using animal-borne imaging to assess green turtle (Chelonia mydas) foraging ecology in Moreton Bay, Australia. Marine Technology Society Journal, 41(4), 9-13. https://doi.org/https://doi.org/10.4031/002533207787441953.

Atkinson, A. M. J., \& Smith, S. V. (1983). C : N : P ratios of benthic marine plants. Limnology and Oceanography, 28(3), 568-574.

Bjorndal, K. A. (1980). Nutrition and grazing behavior of the green turtle Chelonia mydas. Marine Biology, 56(2), 147-154. https://doi.org/10.1007/BF00397131.

Blumenthal, D. (2005). Interrelated causes of plant invasion. Science, 310(5746), 243244. https://doi.org/10.1126/science.1114851.

Blumenthal, D. M. (2006). Interactions between resource availability and enemy release in plant invasion. Ecology Letters, 9(7), 887-895. https://doi.org/10.1111/j.14610248.2006.00934.x.

Brand, S. J. (1995). Diet selection by juvenile green turtles, Chelonia mydas, in subtropical Flathead Gutter, Moreton Bay. University of Queensland.

Burkholder, D. A. et al. (2013). Patterns of top-down control in a seagrass ecosystem: could a roving apex predator induce a behaviour-mediated trophic cascade? The Journal of Animal Ecology, 82(6), 1192-1202. https://doi.org/10.1111/13652656.12097.

Burkholder, D. A. et al. (2011). Diversity in trophic interactions of green sea turtles Chelonia mydas on a relatively pristine coastal foraging ground. Marine Ecology Progress Series, 439, 277-293. https://doi.org/10.3354/meps09313. 
Calenge, C. (2006) The package adehabitat for the R software: a tool for the analysis of space and habitat use by animals. Ecological Modelling, 197, 516-519.

Carr, A. et al. (1982). Survey sof sea turtle populations and habitats in the western atlantic. Panama City, FL. http://www.sefsc.noaa.gov/turtles/TM_91_Carr_etal.pdf.

Christianen, M. J. A. et al. (2018). Megaherbivores may impact expansion of invasive seagrass in the Caribbean. Journal of Ecology, (May), 1-13. https://doi.org/10.1111/1365-2745.13021.

Cogni, R. (2010). Resistance to plant invasion? a native specialist herbivore shows preference for and higher fitness on an introduced host. Biotropica, 42(2), 188-193. https://doi.org/10.1111/j.1744-7429.2009.00570.x.

Debrot, A. O. et al. (2012). Baseline surveys of Lac Bay benthic and fish communities, Bonaire (No. C129/12). IMARES.

De Iongh, H. H. et al. (2007). A review of research on the interactions between dugongs (Dugong dugon Müller 1776) and intertidal seagrass beds in Indonesia. Hydrobiologia, 591(1), 73-83. https://doi.org/10.1007/s10750-007-0785-4.

Dirzo, R. et al. (2015). Collapse of the world's largest herbivores. Science Advances, 1(4), e1400103. https://doi.org/10.1126/sciadv.1400103.

Duarte, C. M. (1990). Seagrass nutrient content. Marine Ecology Progress Series, 67(April), 201-207-207. https://doi.org/10.3354/meps067201.

Estes, J. A., and Palmisano, J. F. (1974). Sea otters: their role in structuring nearshore communities. Science, 185(4156), 1058-1060. https://doi.org/10.1126/science.185.4156.1058.

Fourqurean, J. W., and Cai, Y. (2001). Arsenic and phosphorus in seagrass leaves from the Gulf of Mexico. Aquatic Botany, 71(4), 247-258. https://doi.org/10.1016/S03043770(01)00193-0.

Fourqurean, J. W. et al. ( (1997). Spatial and temporal variation in C:N:P ratios, $\delta 15 \mathrm{~N}$, and $\delta 13 \mathrm{C}$ of eelgrass Zostera marina. Marine Ecology Progress Series, 157(October), 147-157.

Fuentes, M. M. P. B., Lawler, I. R., and Gyuris, E. (2006). Dietary preferences of juvenile green turtles (Chelonia mydas) on a tropical reef flat. Wildlife Research, 33, 671-678. Retrieved from http://www.publish.csiro.au/?paper=WR05081. 
Grosholz, E. (2010). Avoidance by grazers facilitates spread of an invasive hybrid plant. Ecology Letters, 13(2), 145-153. https://doi.org/10.1111/j.1461-0248.2009.01409.x.

Gruner, D. S. et al. (2008). A cross-system synthesis of consumer and nutrient resource control on producer biomass. Ecology letters, 11(7), 740-755.

Hatase, H. et al. (2002). Population structure of loggerhead turtles, Caretta caretta, nesting in Japan: bottlenecks on the Pacific population. Marine Biology, 141(2), 299-305. https://doi.org/10.1007/s00227-002-0819-4.

Heckman, R. W., Wright, J. P., \& Mitchell, C. E. (2016). Joint effects of nutrient addition and enemy exclusion on exotic plant success. Ecology, 97(12), 3337-3345. https://doi.org/10.1002/ecy.1585.

Heithaus, M. R. et al. (2014). Seagrasses in the age of sea turtle conservation and shark overfishing. Frontiers in Marine Science, 1(August), 1-6. https://doi.org/10.3389/fmars.2014.00028.

Heithaus, M. R. et al. (2008). A review of lethal and non-lethal effects of predators on adult marine turtles. Journal of Experimental Marine Biology and Ecology, 356(12), 43-51. https://doi.org/10.1016/j.jembe.2007.12.013.

Jackson, J. B. C. (2001). What was natural in the coastal oceans? Proceedings of the National Academy of Sciences of the United States of America, 98(10), 5411-8. https://doi.org/10.1073/pnas.091092898.

Johnson, M. W., Heck, K. L., \& Fourqurean, J. W. (2006). Nutrient content of seagrasses and epiphytes in the northern Gulf of Mexico: Evidence of phosphorus and nitrogen limitation. Aquatic Botany, 85(2), 103-111. https://doi.org/10.1016/j.aquabot.2006.02.003

Jones, C. G., Lawton, J. H., \& Shachak, M. (1994). Organisms as ecosystem engineers. Oikos, 69(3), 373-386. http://link.springer.com/chapter/10.1007/978-1-4612-40181_14.

Jones, T. T., \& Seminoff, J. A. (2013). Feeding biology: advances from field-based observations, physiological studies, and molecular techniques. In The biology of sea turtles: Volume III. pp. 211-247.

Kalisz, S., Spigler, R. B., \& Horvitz, C. C. (2014). In a long-term experimental demography study, excluding ungulates reversed invader's explosive population growth rate and restored natives. Proceedings of the National Academy of Sciences, 111(12), 4501-4506. https://doi.org/10.1073/pnas.1310121111 
Keane, R., \& Crawley, M. (2002). Exotic plant invasions and the enemy release hypothesis. Trends in Ecology \& Evolution, 17(4), 164-170. https://doi.org/https://doi.org/10.1016/S0169-5347(02)02499-0.

Kerninon, F. (2012). Première actions de mis en place d'un réseau d'observation des herbiers de l'Outre-mer (First actions in setting up an overseas seagrass monitoring network. Universite de Bretagne Occidentale.

Limpus, C. J., Couper, P. J., \& Read, M. (1994). The green turtle, Chelonia mydas, in Queensland: population structure in a warm temperate feeding area. Memoirs of the Queensland Museum, 35(1), 139-154.

Limpus, C. J., \& Reed, P. C. (1985). Green Sea Turtles Stranded by Cyclone Kathy on the South-Westeern Coast of the Culf of Carpentaria. Wildlife Research, 12(3), 523533.

López-Mendilaharsu, M. et al., R. (2005). Identifying critical foraging habitats of the green turtle (Chelonia mydas) along the Pacific coast of the Baja California peninsula, Mexico. Aquatic Conservation: Marine and Freshwater Ecosystems, 15(3), 259-269. https://doi.org/10.1002/aqc.676.

Manly B. F. J. et al. (2002). Resource selection by animals: statistical design and analysis for field studies, 2nd edn. Springer Science \& Business Media. Kluwer, Dordrecht.

Maron, J. L. et al. (2014). Staged invasions across disparate grasslands: Effects of seed provenance, consumers and disturbance on productivity and species richness. Ecology Letters, 17(4), 499-507. https://doi.org/10.1111/ele.12250.

McCook, L. J., Jompa, J., \& Diaz-Pulido, G. (2001). Competition between corals and algae on coral reefs: A review of evidence and mechanisms. Coral Reefs, 19(4), 400-417. https://doi.org/10.1007/s003380000129.

Mendonça, M. T. (1983). Movements and feeding ecology of immature green turtles (Chelonia mydas) in a Florida lagoon. Copeia, 1983(4), 1013-1023.

Meylan, A. (1983). Marine turtles of the Leeward Islands, Lesser Antilles. Atoll Research Bulletin (USA), No. 278(December), 1-24. https://doi.org/10.5479/si.00775630.278.1.

Parker, J. D., Burkepile, D. E., \& Hay, M. E. (2006). opposing effects of native and exotic herbivores on plant invasions. Science, 311(March), 1459-1461. https://doi.org/10.1126/science.1121407.

Preen, A. (1995). Impacts of dugong foraging on seagrass habitats: observational and experimental evidence for cultivation grazing. Marine Ecology Progress Series, 124(1-3), 201-213. https://doi.org/10.3354/meps124201. 
Rinaldi, C. et al. (2011). Les tortues marines en côte sous le vent de la Guadeloupe (Antilles françaises). Bulletin de La Société Herpétologique de France, 139(40), 3747.

R Core Team (2016). R: A language and environment for statistical computing. $R$ Foundation for Statistical Computing, Vienna, Austria. URL https://www.Rproject.org/.

Rogers, C. S., Willette, D. A., \& Miller, J. (2014). Rapidly spreading seagrass invades the Caribbean with unknown ecological consequences. Frontiers in Ecology and the Environment, 12(10), 546-547. https://doi.org/10.1890/14.WB.015.

Ross, J. P. (2016). Biology of the Green Turtle, Chelonia mydas, on an Arabian feeding ground. Journal of Herpetology, 19(4), 459-468. https://doi.org/10.2307/1564198.

Ruiz, H., \& Ballantine, D. L. (2004). Occurrence of the seagrass Halophila stipulacea in the tropical west Atlantic. Bulletin of Marine Science, 75(1), 131-135.

Ruiz, H., Ballantine, D. L., \& Sabater, J. (2017). Continued spread of the seagrass Halophila stipulacea in the Caribbean: Documentation in Puerto Rico and the British Virgin Islands. Gulf and Caribbean Research, 28(1), SC5-SC7. https://doi.org/10.18785/gcr.2801.05.

Russell, D. J., \& Balazs, G. H. (2009). Dietary shifts by green turtles (Chelonia mydas) in the Kāne'ohe Bay region of the Hawaiian Islands: a 28-year study. Pacific Science, 63(2), 181-192. https://doi.org/10.2984/049.063.0202.

Russell, D. J., \& Balazs, G. H. (2015). Increased use of non-native algae species in the diet of the Green Turtle (Chelonia mydas) in a primary pasture ecosystem in Hawaii. Aquatic Ecosystem Health and Management, 18(3), 342-346. https://doi.org/10.1080/14634988.2015.1027140.

Russell, D. J. et al. (2003). Discovery of the sea grass Halophila decipiens (Hydrocharitaceae) in the diet of the Hawaiian green turtle, Chelonia mydas. Pacific Science, 57(4), 393-397. https://doi.org/10.1353/psc.2003.0034.

Santos, R. G. et al. (2011). Coastal habitat degradation and green sea turtle diets in Southeastern Brazil. Marine Pollution Bulletin, 62(6), 1297-302. https://doi.org/10.1016/j.marpolbul.2011.03.004.

Seminoff, J. A., Resendiz, A., \& Nichols, W. J. (2002). Diet of east Pacific green turtles (Chelonia mydas) in the central Gulf of California, México. Journal of Herpetology, 36(3), 447-453. https://doi.org/10.1670/00221511(2002)036[0447:DOEPGT]2.0.CO;2. 
Short, F. T. et al. (2010). Halophila stipulacea. The IUCN Red List of Threatened Species. Version 2014.2. <www.iucnredlist.org>. Downloaded on 23 October 2014.

Silliman, B. R. et al. (2014). Livestock as a potential biological control agent for an invasive wetland plant. PeerJ, 2, e567. https://doi.org/10.7717/peerj.567.

Stohlgren, T. J., Schell, L. D., \& Vanden Heuvel, B. (1999). How grazing and soil quality affect native and exotic plant diversity in rocky mountain grasslands. Ecological Applications, 9(1), 45-64. https://doi.org/10.1890/10510761(1999)009[0045:HGASQA]2.0.CO;2.

Thayer, G. W., Engel, D. W., \& A. Bjorndal, K. (1982). Evidence for short-circuiting of the detritus cycle of seagrass beds by the green turtle, Chelonia mydas L. Journal of Experimental Marine Biology and Ecology, 62(2), 173-183. https://doi.org/10.1016/0022-0981(82)90090-9.

Thomson, J. A. et al. (2018). Individual specialization in a migratory grazer reflects longterm diet selectivity on a foraging ground: implications for isotope-based tracking. Oecologia, 1-11.

Weiss, S. B. (2009). Cars, Cows, and Checkerspot Butterflies: Nitrogen Deposition and Management of Nutrient-Poor Grasslands for a Threatened Species. Conservation Biology, 13(6), 1476-1486. https://doi.org/10.1046/j.1523-1739.1999.98468.x.

Willette, D. A. et al. (2014). Continued expansion of the trans-Atlantic invasive marine angiosperm Halophila stipulacea in the Eastern Caribbean. Aquatic Botany, 112, 98-102. https://doi.org/10.1016/j.aquabot.2013.10.001. 


\section{Appendix I.}

Table A. Post-hoc comparisons among macrophytes using the Tukey's test (alpha = 0.05 ) for $\% \mathrm{C}, \% \mathrm{~N}, \mathrm{C}: \mathrm{N}, \mathrm{C}: \mathrm{P}$, and $\mathrm{N}: \mathrm{P}$.

\begin{tabular}{|c|c|c|c|c|c|c|}
\hline \multirow{2}{*}{$\begin{array}{c}\text { Dependent } \\
\text { Variable }\end{array}$} & \multirow[b]{2}{*}{ (I) Species } & \multirow[b]{2}{*}{ (J) Species } & \multirow{2}{*}{$\begin{array}{c}\text { Mean } \\
\text { Difference (I-J) }\end{array}$} & \multirow[b]{2}{*}{ Sig. } & \multicolumn{2}{|c|}{ 95\% Confidence Interval } \\
\hline & & & & & Lower Bound & Upper Bound \\
\hline$\% \mathrm{~N}$ & H. stipulacea & macroalgae & 0.70 & $<0.0001$ & 0.39 & 1.01 \\
\hline$\% \mathrm{~N}$ & S. filiforme & macroalgae & 0.98 & $<0.0001$ & 0.64 & 1.32 \\
\hline$\% \mathrm{~N}$ & S. filiforme & H. stipulacea & 0.28 & 0.09 & -0.04 & 0.60 \\
\hline$\% \mathrm{C}$ & H. stipulacea & macroalgae & 1.52 & 0.00 & 1.41 & 1.65 \\
\hline$\% \mathrm{C}$ & S. filiforme & macroalgae & 1.70 & 0.00 & 1.56 & 1.85 \\
\hline$\% \mathrm{C}$ & S. filiforme & H. stipulacea & 1.11 & 0.01 & 1.03 & 1.21 \\
\hline$\% \mathrm{P}$ & H. stipulacea & macroalgae & 0.12 & 0.00 & 0.10 & 0.15 \\
\hline$\% \mathrm{P}$ & S. filiforme & macroalgae & 0.11 & 0.00 & 0.08 & 0.14 \\
\hline$\% \mathrm{P}$ & H. stipulacea & S. filiforme & 0.01 & 0.54 & -0.01 & 0.04 \\
\hline $\mathrm{C}: \mathrm{N}$ & macroalgae & H. stipulacea & 0.63 & 0.87 & -2.54 & 3.80 \\
\hline $\mathrm{C}: \mathrm{N}$ & macroalgae & S. filiforme & 2.29 & 0.23 & -1.08 & 5.67 \\
\hline$C: N$ & H. stipulacea & S. filiforme & 1.66 & 0.38 & -1.40 & 4.73 \\
\hline$C: P$ & macroalgae & H. stipulacea & 2.44 & 0.00 & 3.07 & 1.00 \\
\hline$C: P$ & macroalgae & S. filiforme & 2.07 & $<0.0001$ & 2.65 & 1.00 \\
\hline$C: P$ & S. filiforme & H. stipulacea & 1.18 & 0.20 & 1.48 & 1.59 \\
\hline$N: P$ & macroalgae & H. stipulacea & 1.22 & $<0.0001$ & 1.55 & 1.32 \\
\hline$N: P$ & macroalgae & S. filiforme & 2.26 & 0.00 & 2.87 & 1.00 \\
\hline$N: P$ & S. filiforme & H. stipulacea & 1.85 & 0.12 & 2.39 & 1.00 \\
\hline
\end{tabular}


Appendix II. Individual selectivity; 30 of the 35 turtles foraged selectively, three selected for the invasive seagrass (H. stipulacea) and 27 positively selected for the native seagrass ( $S$. filiforme); test of habitat selection:

Table B. Selectivity test statistic (Khi2Lj), degrees of freedom (df), $P$; Selection Ratios (Wi) for each resource: H. stipulacea (Hs), S. filiforme (Sf), macroalgae (Algae); Resource with positive selection: NA indicates turtles that did not feed selectively

\begin{tabular}{lccccccc} 
& \multicolumn{2}{c}{ Test of habitat selection } & \multicolumn{2}{c}{ Selection Ratios $(\boldsymbol{W i})$} & \\
\cline { 2 - 8 } TurtlelD & Khi2Lj & df & pvalue & Hs & Sf & Algae & Selection \\
\hline G1501 & 32.02 & 1 & 0 & 0.11 & 4.63 & 0 & $\mathrm{Sf}$ \\
G1502 & 1.12 & 0 & 0 & 1.13 & NaN & 0 & $\mathrm{Hs}$ \\
G1503 & 1.7 & 0 & 0 & 1.17 & 0 & 0 & $\mathrm{Hs}$ \\
G1504 & 31.8 & 1 & 0 & 0.19 & 8.79 & 0 & $\mathrm{Sf}$ \\
G1505 & 47.13 & 0 & 0 & 0 & 6.96 & 0 & $\mathrm{Sf}$ \\
G1506 & 32.37 & 1 & 0 & 0.01 & 5.68 & 0 & $\mathrm{Sf}$ \\
G1507 & 2.2 & 0 & 0 & 1.27 & 0 & 0 & $\mathrm{Hs}$ \\
G1508 & 41.16 & 0 & 0 & 0 & 5.75 & 0 & $\mathrm{Sf}$ \\
G1509 & 29.05 & 1 & 0 & 0.14 & 7.09 & 0 & $\mathrm{Sf}$ \\
G1510 & 34.44 & 0 & 0 & 0 & 5.11 & 0 & $\mathrm{Sf}$ \\
G1601 & 23.07 & 1 & 0 & 0.22 & 4.23 & 0 & $\mathrm{Sf}$ \\
G1602 & 31.83 & 1 & 0 & 0.06 & 5.76 & 0 & $\mathrm{Sf}$ \\
G1603 & 41.15 & 1 & 0 & 0.02 & 8.07 & 0 & $\mathrm{Sf}$ \\
G1604 & 20.44 & 2 & 0 & 0.24 & 5.09 & 0.02 & $\mathrm{Sf}$ \\
G1605 & 25.11 & 0 & 0 & 0 & 3.75 & 0 & $\mathrm{Sf}$ \\
G1606 & 34.85 & 0 & 0 & 0 & 6.02 & 0 & $\mathrm{Sf}$ \\
G1608 & 13.52 & 2 & 0.0012 & 0.02 & 2.35 & 0.13 & $\mathrm{Sf}$ \\
G1609 & 5.47 & 2 & 0.065 & 0.51 & 2.22 & 0.31 & $\mathrm{NA}$ \\
G1610 & 5.75 & 1 & 0.0165 & 1.39 & 1.43 & 0 & $\mathrm{Sf}$ \\
G1611 & 5.52 & 2 & 0.0634 & 0.48 & 4.05 & 0.05 & $\mathrm{NA}$ \\
G1612 & 4.83 & 2 & 0.0893 & 0.35 & 1.86 & 0.21 & $\mathrm{NA}$ \\
G1613 & 15.01 & 2 & 0.0005 & 0.64 & 3.57 & 0.15 & $\mathrm{Sf}$ \\
G1614 & 47.67 & 1 & 0 & 0 & 7.56 & 0.28 & $\mathrm{Sf}$ \\
G1615 & 20.69 & 2 & 0 & 0.03 & 9.39 & 0.29 & $\mathrm{Sf}$ \\
G1617 & 16.57 & 1 & 0 & 0.02 & 1.98 & $\mathrm{NaN}$ & $\mathrm{Sf}$ \\
G1618 & 2.7 & 0 & 0 & 0 & 1.78 & 0 & $\mathrm{Sf}$ \\
G1619 & 27.54 & 1 & 0 & 0 & 4.07 & 0.56 & $\mathrm{Sf}$ \\
G1620 & 0.97 & 1 & 0.3259 & 0.78 & 1.46 & 0 & $\mathrm{NA}$ \\
G1621 & 18.43 & 1 & 0 & 0 & 3.52 & 0.01 & $\mathrm{Sf}$ \\
G1622 & 2.31 & 1 & 0.1282 & 0.08 & 1.47 & 0 & $\mathrm{NA}$ \\
G1623 & 10.63 & 0 & 0 & 0 & 2.56 & 0 & $\mathrm{Sf}$ \\
G1624 & 27.13 & 2 & 0 & 0.05 & 5.24 & 0.18 & $\mathrm{Sf}$ \\
G1625 & 14 & 2 & 0.0009 & 0.22 & 3.53 & 0.08 & $\mathrm{Sf}$ \\
G1626 & 24.13 & 0 & 0 & 0 & 2.77 & 0 & $\mathrm{Sf}$ \\
G1627 & 16.14 & 0 & 0 & 0 & 3.41 & 0 & $\mathrm{Sf}$ \\
\hline & & & & & & &
\end{tabular}




\section{Appendix III.}

Figure A. Selectivity indices for $H$. stipulacea (Hs), S. filiforme (Sf), and macroalgae (Algae) during multiple follows of individual turtles; G1501, G1504, G1608, and G1621 were followed twice each; G1604 and G1611 were followed four times each; asterisk denotes differences in selection among follows of the same individual
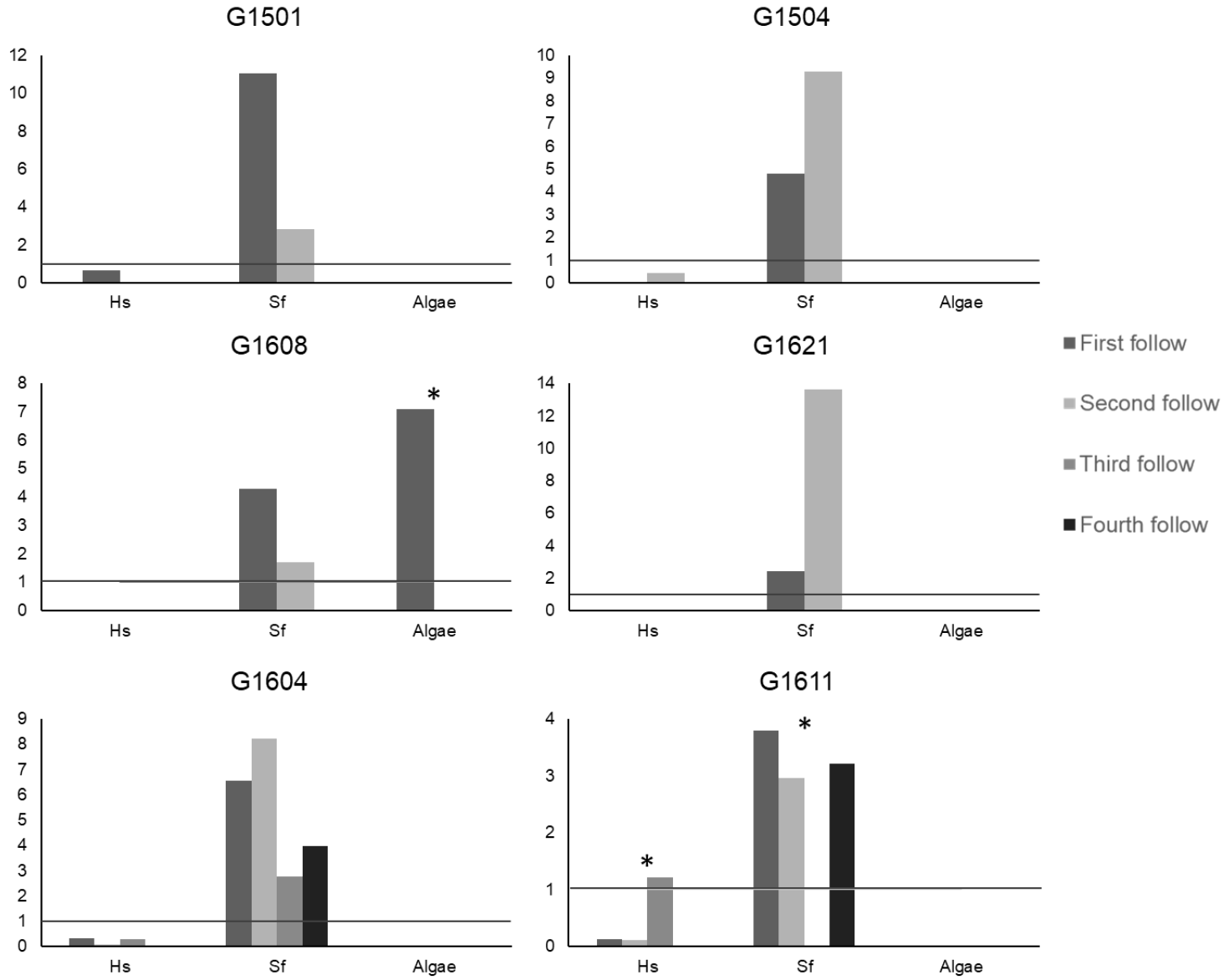
VI. GENERAL CONCLUSIONS 
Understanding factors affecting habitat use and resource selection of herbivores at multiple scales is critical for understanding their potential roles in ecosystems and predicting how they, and their ecosystems, might respond to environmental or anthropogenic disturbance (Binzer et al., 2016; Mougi and Kondoh, 2016; Augustine and Frank, 2017). For green turtles, and countless other species across virtually all ecosystem types, such an understanding is important because of the major changes occurring in ecosystems from climate change to apex predator overharvesting and species invasions. In this dissertation, I used existing variation in conditions across the Caribbean Sea to investigate hierarchical habitat and resource selection by a model marine herbivore to better understand how they respond to variation in their habitats.

In Abaco, The Bahamas, I quantified spatial variation in the relative abundance of potential turtle predators within one of the world's few shark sanctuaries (Chapter 2) and used these data and surveys of primary producer abundance and quality to explore resource selection at multiple scales and levels by green turtles (Chapter III). Using IFD theory I developed testable predictions to help elucidate factors driving space use at the landscape scale and patch selection (third order). In Chapter II, I found that shark species richness was high in both reef and seagrass-dominated bay habitats, although shark diversity and species-level occurrence differed between habitat types and even among reef sites in Abaco. I identified nine shark species (Carcharhinus acronotus, Carcharhinus limbatus, Carcharhinus perezi, Galeocerdo cuvier, Ginglymostoma cirratum, Negaprion brevirostris, Rhizoprionodon spp., Sphyrna mokarran, and Sphyrna tiburo). The species most likely to prey on sea turtles, G. cuvier (tiger sharks), were observed nearly exclusively in the seagrass lagoons, but never in creek habitats. 
In Chapter III, I found that at the site level (third order selection), green turtles did not conform to a basic Ideal Free Distribution (IFD) based on food abundance alone. Indeed, at broad spatial scales it appears that turtles are not using foraging habitats with the most abundant food resources. Turtles were rarely seen in dangerous open waters where seagrass was most abundant. Instead, turtles appear to conform to the foraging arena hypothesis (Walters and Juanes, 1993), with habitat use restricted to safer habitats, but space use within these habitats positively correlated with nitrogen content (i.e., higher quality). Therefore, it is likely that turtles, historically, did not use all available seagrass habitats when predator presence region-wide was higher (Ward-Paige et al., 2010) and, as suggested by Heithaus et al. (2008), reconstructions of Caribbean turtle populations that assume equal use of all seagrass habitats may overestimate historical populations. Within foraging habitats, however, turtles do appear to select high quality seagrass patches relative to nutrient content. In Abaco, their forage selection may be partially driven by the presence of allochthonous nutrient inputs and foraging dynamics of turtles likely reflect a dynamic interplay of biotic and abiotic drivers. Tidal creeks may be particularly critical habitats for rebuilding sea turtle populations. The protected shark populations in Abaco may be preventing unchecked grazing by green turtles, and the exchange of individuals from the invulnerable (creek) to the vulnerable (open water) population components could signal that the preferred habitat has reached carrying capacity.

In Chapters IV and V, I explored another potential factor that could constrain turtle use of apparent foraging resources in the shape of invasive seagrasses. In Chapter IV, Investigated both third order habitat selection of green turtles off the French West 
Indies islands of Guadeloupe, Martinique, and St. Martin. At all sites, turtles selected for areas with abundant native seagrasses (Thalassia testudinum, Syringodium filiforme) and avoided areas typified by macroalgae and the invasive seagrass $H$. stipulacea. In Chapter $\mathrm{V}$, I investigated fourth order resource selection and found that turtles showed a clear preference for native seagrass species, particularly Syringodium filiforme and $T$. testudinum and avoided $H$. stipulacea and macroalgae. While most individual turtles preferred native species, $c a .12 \%$ of individuals in Guadeloupe fed primarily on $H$. stipulacea during follows. Analysis of seagrass $\mathrm{CN}$ content did not reveal significant differences among the species, suggesting that turtles likely are not recognizing the invasive species as potential forage rather than selectively foraging on higher quality seagrasses. Together, the work in Chapters IV and V suggest that the green turtleinvasive seagrass interaction conforms to the Rare Enemy Hypothesis and that green turtles likely facilitate the invasion of $H$. stipulacea since they tend to avoid foraging on this species even when it is at high relative abundance. Furthermore, the spread of invasive seagrasses may result in decreases in habitat area that turtles perceive as quality foraging habitat, restricting energy flow into the turtle population and potentially reducing carrying capacities of habitats.

Green turtles in the Caribbean currently face tradeoffs (quantity-quality and energy-risk) in their foraging habitat use, and their ability to adapt to changing ecosystem conditions will affect the growth trajectory of their populations. If turtles have access to habitats such as the tidal creeks in Abaco that offer both adequate forage and refuge from predation, they can afford to forage selectively for high quality forage. At the population level, green turtles are not selecting to forage on the highly invasive seagrass $H$. 
stipulacea. The continued avoidance of an abundant forage option would mean turtles are self-imposing a foraging habitat constraint that could lead to lower energy intake and lower K. However, should green turtles incorporate H. stipulacea into their diets in the manner that Hawaiian green turtles incorporated invasive macrophytes into their diets (Russell and Balazs, 2015), they would have greater foraging habitat and the potential to increase their energy intake and $\mathrm{K}$.

I investigated the foraging habitat use of green turtles in the broad context of a relatively intact shark population and abundant forage in Abaco, and in the context of a seagrass invasion in the FWI. However, these contexts are dynamic and there are likely interactions with factors not studied here that drive, at least in part, foraging habitat use. Shark conservation efforts could lead to increased risk and further habitat constraints. The interaction of increased predation risk with the $H$. stipulacea invasion could go one of two ways. If turtles do not incorporate invasive seagrass into their diets their populations may especially vulnerable when their available habitat is constrained by both predation risk and the invasion. If turtles do incorporate $H$. stipulacea into their diets, the interaction of the invasion with increased predation risk could mean that the constraint of predation risk is mitigated by the increased forage available. Further research is needed to elucidate the implications of the interactions between factors affecting large herbivore habitat use and given that predation risk and invasive species are not unique to the marine environment, the results from research into green turtle foraging habitat use can be directly applied to management strategies of similar ecosystems. 


\section{References}

Augustine, D. J., \& Frank, D. A. (2001). Effects of migratory grazers on spatial heterogeneity of soil nitrogen properties in a grassland ecosystem. Ecology, 82(11), 3149-3162. https://doi.org/10.1890/00129658(2001)082[3149:EOMGOS]2.0.CO;2.

Binzer, A. et al. (2016). Interactive effects of warming, eutrophication and size structure: Impacts on biodiversity and food-web structure, Global Change Biology, 22(1), pp. 220-227. doi: 10.1111/gcb.13086.

Christianen, M. J. A. et al. (2018). Megaherbivores may impact expansion of invasive seagrass in the Caribbean, Journal of Ecology, pp. 0-1. doi: 10.1111/13652745.13021.

Heithaus, M. R. et al. (2008). Predicting ecological consequences of marine top predator declines, Trends in Ecology and Evolution, 23(4), pp. 202-210. doi: 10.1016/j.tree.2008.01.003.

Mougi, A. and Kondoh, M. (2016). Food-web complexity, meta-community complexity and community stability, Scientific Reports. Nature Publishing Group, 6(November 2015), pp. 1-5. doi: 10.1038/srep24478.

Russell, D. J. and Balazs, G. H. (2015). Increased use of non-native algae species in the diet of the Green Turtle (Chelonia mydas) in a primary pasture ecosystem in Hawaii, Aquatic Ecosystem Health and Management, 18(3), pp. 342-346. doi: 10.1080/14634988.2015.1027140.

Walters, C. J. and Juanes, F. (1993). Recruitment limitation as a consequence of natural selection for use of restricted feeding habitats and predation risk taking by juvenile fishes, Canadian Journal of Fisheries and Aquatic Sciences, 50(10), pp. 2058-2070. doi: 10.1139/f93-229.

Ward-Paige, C. a et al. (2010). Large-scale absence of sharks on reefs in the greaterCaribbean: a footprint of human pressures, PloS one, 5(8), p. e11968. doi: 10.1371/journal.pone.0011968. 
VITA

\section{ELIZABETH R. WHITMAN}

Born, Casper, Wyoming

2008-2011

M.Sc. Environmental Sciences

University of Virginia

Charlottesville, Virginia

2000-2006

B.A. Communications

Purdue University

West Lafayette, Indiana

\section{PUBLICATIONS AND SELECT PRESENTATIONS}

D’Odorico, P., T. Scanlon, C. Runyan, K. Abshire, P. Barrett, ... E. Whitman. 2009.

Dryland Ecohydrology: Research perspectives. Annals of Arid Zone. 48(3), 1-29.

Rees, A., Avens, L., Ballorain, K., Bevan, E., Broderick, A., ... Godley, B. (2017). The potential of unmanned aerial systems for sea turtle research and conservation: a review and future directions. Endangered Species Research, 35, 81-100. https://doi.org/10.3354/esr00877.

Reidenbach, M. A., P. Berg, C. R. Hansen and E. R. Whitman. 2013. Effects of boundary layer flow on suspended sediment and oxygen exchange for intertidal oyster reefs. Limnology and Oceanography: Fluids and Environments 3(1), 225-239.

Thomson, J. A., Whitman, E. R., Garcia-Rojas, M. I., Bellgrove, A., Ekins, M., Hays, G. C., \& Heithaus, M. R. (2018). Individual specialization in a migratory grazer reflects long-term diet selectivity on a foraging ground: implications for isotopebased tracking. Oecologia, 1-11.

Whitman, E. R. "The foraging ecology of green turtles in the Caribbean" Oral: Cape Eleuthera Institute Earthwatch. Eleuthera, The Bahamas. Oct. 2017.

Whitman, E. R. "Sea turtle research \& the path to graduate school" Oral: Florida Atlantic University Marine Biology Club Seminar Series. Jupiter, FL. Apr. 2017.

Whitman, E. R. "Marine turtle dive behavior and data analysis: integrating software and traditional dive types" Oral: Symposium on Sea Turtle Biology \& Conservation. Baltimore, MD. Feb. 2013.

Whitman, E. R., M. Bond, M. R. Heithaus. "Shark distributions and the risk landscape for green turtles in Abaco, Bahamas" Oral: Abaco Science Alliance Conference. Marsh Harbour, Abaco, Bahamas. Jan. 2018. 
Whitman, E. R., M. R. Heithaus. "The role of food availability and predation risk in habitat use of Caribbean green turtles" Oral: Biosymposium. FIU, North Miami, FL. Feb. 2018.

Whitman, E. R., M. R. Heithaus, L. García Barcia, N. Brito, C. Rinaldi, J. J. Kiszka. "Interaction between green sea turtles \& the invasive seagrass H. Stipulacea in the Caribbean" Oral: Symposium on Sea Turtle Biology \& Conservation. Las Vegas, NV. Apr. 2017.

Whitman, E. R., M. R. Heithaus, L. García Barcia, N. Brito, C. Rinaldi, J. J. Kiszka. "Interaction between green sea turtles \& the invasive seagrass H. Stipulacea in the Caribbean” Oral: Graduate Student Scholarly Forum. FIU, Miami, FL. Mar. 2017.

Whitman, E. R., Jones, T. Todd, Bayless, A., Resendiz, A., and Seminoff, Jeffrey A. "Dive behavior and activity budgets of green turtles, Chelonia mydas, at a warm temperate foraging area in the Gulf of California, Mexico" Oral: Protected Resources Div. Science \& Issues seminar series. NOAA Southwest Fisheries Science Center, San Diego, CA. May 2012.

Whitman, E. R., Jones, T. Todd, Bayless, A., Resendiz, A., and Seminoff, Jeffrey A. "Dive behavior and activity budgets of green turtles, Chelonia mydas, at a warm temperate foraging area in the Gulf of California, Mexico" Oral: Symposium on Sea Turtle Biology \& Conservation. Huatulco, Oaxaca, Mexico. Mar. 2012.

Whitman, E. R., J. Kiszka, K. Gastrich, J. Kilfoil and M. R. Heithaus "UAV research and lessons learned” Oral: Symposium on Sea Turtle Biology \& Conservation: UAV workshop. Las Vegas, NV. Apr. 2017.

Whitman, E. R. and M. A. Reidenbach. 2012. Benthic flow environments affect recruitment of Crassostrea virginica larvae to an intertidal oyster reef. Marine Ecology Progress Series. 463, 177-191.

Whitman, E. R. and M. A. Reidenbach. "Hydrodynamics affecting larval transport \& settlement onto intertidal oyster reefs" Oral: LTER, Anheuser Busch Coastal Research Center Seminar. Oyster, VA. Jun. 2011.

Whitman, E. R. and M. A. Reidenbach. "Hydrodynamics affecting larval transport \& settlement onto intertidal oyster reefs" Poster: Society for Ecological Restoration, Mid-Atlantic Chapter Annual Meeting. University of Maryland, College Park. Apr. 2011.

Whitman, E. R. and M. A. Reidenbach. "Hydrodynamics of intertidal oyster reefs" Poster: UVA's Enviro Days. Charlottesville, VA. Jan. 2010. 